\title{
A Regulação do Trabalho E A AÇão SindiCAl EM Perspectiva Comparada: Brasil e Grã-Bretanha
}

\author{
Dissertação apresentada como requisito parcial \\ à obtenção do grau de mestre, na área de \\ concentração de Filosofia e Teoria Geral do \\ Direito, na Faculdade de Direito da \\ Universidade de São Paulo.
}

Professor Orientador Celso Fernandes Campilongo

\author{
FACULDADE DE DIREITO \\ UNIVERSIDADE DE SÃO PAULO
}

\author{
SÃO PAULO \\ 2008
}


Banca Examinadora:

Professor Orientador Celso Fernandes Campilongo

São Paulo, de de 2009 
Para Eny, Isidore e Juliana. 


\section{AGRADECIMENTOS}

Estou convicto que o conhecimento é produto de uma forma de razão comunicativa. Todas as idéias, reflexões e argumentos aqui presentes dependeram de prévia verbalização e diálogo com a viva comunidade acadêmica que encontrei em São Paulo e Londres. Esta é apenas uma forma ligeiramente distinta de afirmar que carrego enorme dívida para com todos aqueles com os quais tive o privilégio de manter um diálogo permanente a respeito deste trabalho, dentre os quais incluo o Professor Celso Fernandes Campilongo, a quem muito devo pela orientação segura, além da enorme confiança a mim conferida, o Professor José Eduardo Faria, que compartilha da responsabilidade maravilhosa de haver promovido meu apreço pela sociologia jurídica, na graduação e no PET, aos professores dos departamentos de Ciência Política e Sociologia da Universidade de São Paulo com os quais realizei cursos de pós-graduação e, em especial, ao Professor Iram Jácome Rodrigues, cujo curso constituiu uma verdadeira iniciação ao mundo do sindicalismo brasileiro. Devo, ainda, aos Professores Nigel Dodd e Robin Acher, do Departamento de Sociologia da London School of Economics and Political Science (LSE), pela acolhida, as importantes informações e o rigoroso debate sobre minha pesquisa.

Dentre os inúmeros colegas que me estimularam e teceram importantes observações sobre este trabalho ou outras questões que me auxiliaram a interpretar fenômenos aqui analisados, sou especialmente grato à minha permanente e mais compreensível interlocutora, Juliana Benedetti, mas também aos Professores Diogo Coutinho e Guilherme Leite Gonçalves, a Adriano Martinho, Júlio José Araújo Jr., Flávio Batista, Daniel Degensjazn, Eduardo Saad Diniz, Caio de Freitas Quero e Marco Antônio de C. Granieri. Sou, ainda, grato aos funcionários das bibliotecas da Universidade de São Paulo e da LSE que me abriram as portas para os incríveis acervos de fontes de pesquisa que encontrei em ambas. Esta dissertação deve muito a todos esses e outros que fatalmente minha memória trai. Mas se suas qualidades foram obtidas por meio da comunicação permanente com eles, o mesmo não pode ser dito sobre suas falhas e limitações. Sou inteiramente responsável por elas. 


\section{RESUMO}

Esta dissertação compara historicamente dois modelos nacionais de regulação jurídica das relações de trabalho - o brasileiro e o britânico -, opostos no papel que o direito desempenha, com o intuito de avaliar seus impactos nos padrões específicos de ação sindical verificados nessas duas nações. Ela analisa a formação, transformações e a resiliência de algumas instituições, políticas e valores relacionados à regulação das relações de trabalho e os padrões resultantes de ação sindical nessas duas nações. Empregando um modelo explicativo informado pelo institucionalismo histórico e pela teoria das oportunidades políticas, procura demonstrar que o processo de construção e desenvolvimento de modelos nacionais de regulação jurídica do trabalho são dependentes de sua própria trajetória (path-dependent) e que esses modelos mobilizam instituições, políticas e valores, além de angariar apoio social, fatores que freqüentemente se tornam enraizados e interagem dinamicamente em circunstâncias concretas influenciando as preferências dos atores.

Palavras-chave: Regulação do trabalho; ação coletiva; institucionalismo histórico; sindicalismo no Brasil; sindicalismo na Grã-Bretanha. 


\begin{abstract}
This dissertation historically compares two national models of legal regulation of employment relations - the Brazilian and the British -, opposite in the role that law plays, in order to assess their impacts on the specific patterns of trades unions' action verified in these two nations. It analyses the formation, transformations and the resilience of some institutions, policies and values regarding the regulation of employment relations and the resulting patterns of trades unions' action in these two nations. Employing an explanatory model informed by the historical institutionalism and the political opportunities theory, it attempts to demonstrate that the process of construction and development of national models of legal regulation of labour are path-dependent and that these models mobilise institutions, policies and values, besides eliciting social support, factors that often become entrenched and interact dynamically in concrete circumstances shaping the preferences of actors.
\end{abstract}

Key-Words: Labour regulation; collective action; historical institutionalism; trade unionism in Brazil; trade unionism in Great Britain. 


\section{SUMÁRIO}

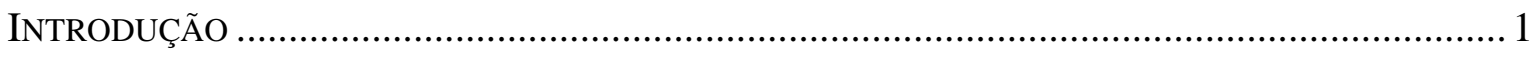

Causalidade adequada e o método comparativo histórico ………………………………....13

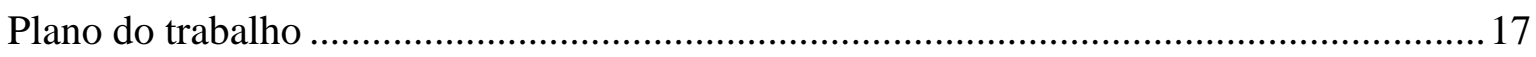

1. Um Marco para a Análise da Regulação das RelaÇões de trabalho e Seus

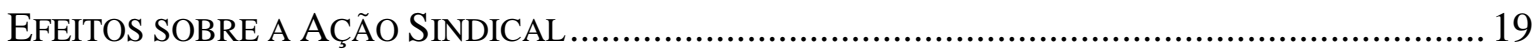

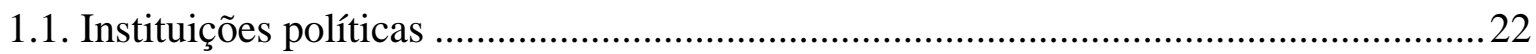

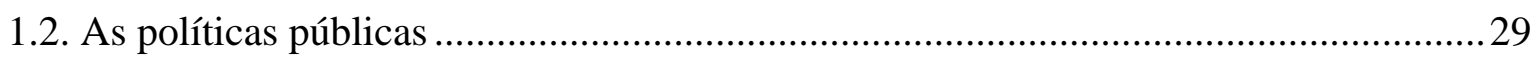

1.3. Forças sociais de apoio aos sindicatos e ao aparato de regulação ....................................34

1.4. As interações entre os elementos: o modelo explicativo em ação ....................................37

2. A ORDEM PARA O PROGRESSO: A REGULAÇÃO DO TRABALHO No BRASIL ............................39

2.1. Alguns antecedentes na formação do operariado e sua ação coletiva .............................4

2.2. 1930-1945: A fundação do aparato corporativo no Brasil na Era Vargas ...................... 49

2.2.1. Fundação e elementos de formação do modelo corporativo ................................. 49

2.2.2. Características e resultados do modelo corporativo ..............................................61

2.3. 1945-1964: O intervalo democrático ..........................................................................74

2.4. 1964-1988: Consolidação e esgotamento do modelo ………………………………......79

2.5. De 1988 aos dias de hoje: permanência do modelo e precarização das relações de

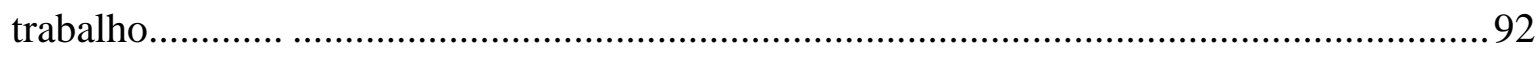

3. Unidos, Nós Perdemos: A Regulação Do Trabalho Na Grã-Bretanha ............... 102

3.1 A regulação jurídica na produção do trabalho assalariado .............................................108

3.2 A proibição da ação sindical e as duas frentes de batalha ...............................................115

3.2.1. As primeiras associações de trabalhadores - o mercado como fator de

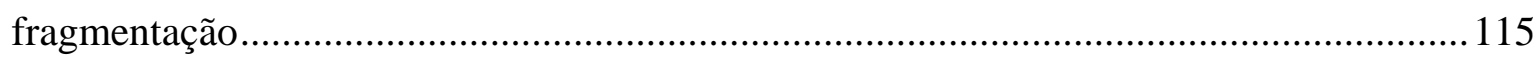

3.2.2. A proibição das associações - a repressão como fator de união .........................119

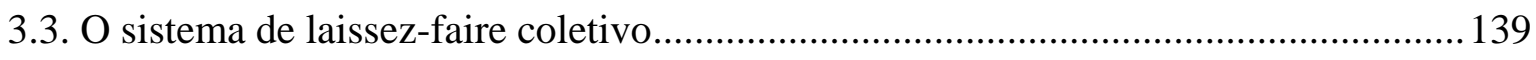

3.3.1. O período de negociação setorial....................................................................139

3.3.2. A crise, sua narrativa e seu diagnóstico pela Comissão Donovan......................149

3.3.3. Tentativas de reforma negociada ................................................................. 157

3.4. A descoletivização da regulação do trabalho...............................................................165 
3.5. O legado dos modelos regulatórios na Grã-Bretanha e seus impactos sobre a ação

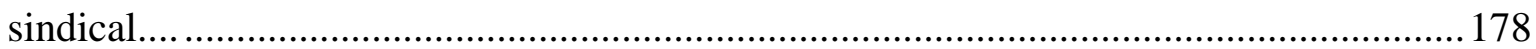

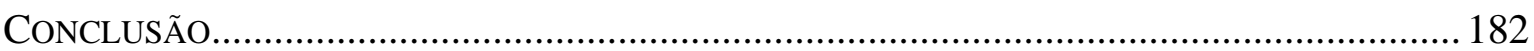

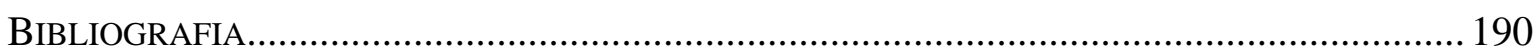




\section{INTRODUÇÃo}

"Poderia dizer-me, por favor, qual caminho eu devo tomar desde aqui?"

"Isso depende em grande medida de para onde você quer ir", disse o Gato.

"Eu não me importo muito para onde - " disse Alice.

"Então não importa o caminho que você tome”, disse o Gato.

“- contanto que eu chegue a algum lugar”, Alice completou como uma explicação.

"Oh, você pode ter certeza que irá chegar”, disse o Gato, "desde que você ande o suficiente”.

Alice sentiu que isso não poderia ser negado, então ela tentou outra questão. "Que tipo de pessoas vivem por ali?"

"Nessa direção”, disse o gato, acenando em círculo com sua pata direita, "vive um Chapeleiro, e naquela direção," acenando com sua outra pata, "vive uma Lebre de Março. Visite qualquer um que você queira: eles são ambos loucos."

"Mas eu não quero ficar entre pessoas malucas”, Alice observou.

"Oh, você não pode evitar isso", disse o Gato, "nós somos todos loucos aqui. Eu sou louco. Você é louca."

"Como você sabe que eu sou louca?" disse Alice.

"Você deve ser," disse o Gato, "ou você não teria vindo para cá”.

(CARROLL, Lewis. Alice's adventures in Wonderland. New York: McLoughlin Brothers, 1940, p. 89-90. Traduz-se) $)^{1}$.

Esse fragmento de Alice no País das Maravilhas revela uma situação bastante particular que nos causa grande estranheza. Essa sensação deriva do fato do episódio descrever uma situação exótica, absolutamente incomum na vida social, que só pode ser fruto da imaginação ou da insanidade, como as próprias personagens da fantasia de Carroll admitem ao final do fragmento. Tendo diante de si dois caminhos diversos para escolher, Alice pede ajuda ao Gato. Até então, durante grande parte de sua jornada onírica pelo País das Maravilhas, Alice havia se limitado a seguir o Coelho Branco e em sua vida real, como é possível inferir das primeiras páginas do conto, as convenções sociais vitorianas haviam imposto a Alice uma vida tediosa e guiada por valores rígidos. Nesse momento, porém, Alice é totalmente livre para escolher qual curso de ação tomar, embora não esteja certa. O Gato sugere-lhe, então, que determine o destino ao qual pretende chegar, para então escolher o caminho. Trata-se de uma solução própria da sociedade moderna, uma ação

\footnotetext{
${ }^{1}$ No original: "Would you tell me, please, which way I ought to walk from here?"

"That depends a good deal on where you want to get to", said the Cat.

"I don't much care where - " said Alice.

"Then it doesn't matter which way you walk", said the Cat.

“----- so long as I get somewhere", Alice added as an explanation.

"Oh, you're sure to do that", said the Cat, "if you only walk long enough."

Alice felt that this could not be denied, so she tried another question. "What sort of people live about here?"

"In that direction," the Cat said, waving its right paw round, "lives a Hatter: and in that direction,", waving the other paw, "lives a March Hare. Visit either you like: they're both mad."

"But I don't want to go among mad people," Alice remarked.

"Oh, you can't help that”, said the Cat: "we're all mad here. I'm mad. You're mad."

"How do you know I'm mad?” said Alice.

“You must be,” said the Cat, “or you wouldn't have come here.” (CARROLL, 1940, p. 89-90).
} 
racional com relação a fins, fruto do sopesamento racional entre meios, fins e conseqüências da ação, na qual os meios concorrentes são analisados, e a escolha entre eles determinada, à luz de sua pertinência e eficiência para atingir uma finalidade definida previamente pelo agente para satisfazer uma preferência ou prioridade (WEBER, 2004, p. 20). A situação representa uma oportunidade única, na qual Alice pode escolher livre e racionalmente os rumos de sua ação, mas ainda assim a personagem mostra-se absolutamente indiferente e rejeita a sugestão do Gato. Para ela, envolta na fantasia daquele mundo, bastava chegar a qualquer lugar e o Gato, ao indicar a insanidade que subjazia à situação e tornava os caminhos disponíveis semelhantes, parece referendar a indiferença de Alice ressaltando que, nesse mundo incomum, as escolhas dos cursos de ação não têm conseqüências diversas ${ }^{2}$.

Certamente, toda essa situação só poderia ser possível em uma fantasia onírica. O mundo social é absolutamente diverso e nele, as ações não se movem no vazio ou sem constrangimentos. Ao ser social não é facultado escolher livremente dentre os caminhos que pode seguir e dificilmente dispõe ele das informações necessárias para saber, de antemão, qual o meio mais adequado para se atingir certa finalidade. As ações sociais correspondem a escolhas estruturadas por uma constelação de fatores econômicos, políticos e sociais que são, por sua vez, modificados pela ação humana. Desse modo, não apenas as decisões tomadas pelos atores sociais são constrangidas, como também possuem conseqüências sobre eles e sobre o restante da sociedade.

De igual modo, as ações coletivas não se movem livremente no vazio. Os movimentos sociais não têm a oportunidade de, tal como Alice, escolher os cursos de ação mais apropriados para alcançar suas finalidades, isto é, promover seus interesses. Com efeito, os cursos de ação tomados por organizações de interesses são fruto não apenas de suas intenções, mas do mesmo conjunto de fatores estruturantes que constrangem as possibilidades de ação em sociedade.

O foco analítico desta pesquisa é a ação sindical que, como em geral o é a ação dos movimentos sociais, é influenciada por uma série de fatores que estruturam suas possibilidades. Estudos têm relacionado a natureza e força dos movimentos organizados de

\footnotetext{
${ }^{2}$ Nem no mundo fantasioso criado por Carroll a razão é completamente abandonada. A despeito de haver uma certa insanidade nas ações das personagens do Mundo das Maravilhas, há uma lógica própria subjacente às suas ações, nas quais personagens desempenham papéis específicos e reiterados. Ademais, a inocência e aparente despreocupação de Alice pelos rumos de sua vida são complemente abandonadas na continuação Alice através do Espelho, no qual Alice age racionalmente escolhendo os meios para alcançar o pretendido fim de se tornar rainha.
} 
trabalhadores a um complexo de fatores, dentre os quais se pode apontar a realidade socioeconômica, que condiciona o sentimento de privação, a estrutura operacional do movimento e sua capacidade de atrair e mobilizar recursos, os processos coletivos de formação da identidade comum e interpretação tanto da condição do grupo, quanto da necessidade da luta, bem como a estrutura de oportunidades oferecidas e constrangimentos impostos pelas instituições estatais, que limita as opções e condiciona as estratégias de ação (McADAM; TARROW; ZALD, 1996; VISSER, 1992). Em realidade, é a dinâmica interação entre esses múltiplos elementos, em contextos históricos particulares, que determinam o padrão - força e natureza - da ação coletiva dos trabalhadores.

Sem negar a importância desse complexo de fatores e dos efeitos de interação criados entre eles, esta pesquisa pretende focalizar um elemento específico para analisar o seu impacto sobre o desempenho da ação sindical, por julgá-lo determinante. Trata-se do marco legal e do quadro de instituições estatais dirigidos à regulação das relações de trabalho e à interlocução com os interesses dos atores dessas relações. Como apontado previamente por Marks (1989, p. 50), essa moldura legislativa e quadro institucional específicos, no interior dos quais se desenvolve a ação sindical, é um dos elementos políticos que não podem ser negligenciados ao se analisar a ação dos trabalhadores e de seus sindicatos.

Por certo que o aparato de regulação jurídica das relações de trabalho não é o único fator, mas ele parece ser fundamental para compreender a performance da ação sindical por interferir nos demais elementos causais. O modo como o direito e as instituições estatais organizam a ação sindical influencia a identidade coletiva do movimento, que replica as divisões formadas por unidades de articulação profissional definidas pelo marco regulatório, bem como condiciona as formas de organização e obtenção de recursos financeiros e políticos. “Ao final [...]”, como recorda Thompson, “[...] é o contexto político tanto quanto a máquina a vapor, que teve a maior influência sobre a formação da consciência e as instituições da classe trabalhadora” (THOMPSON, 1966, p. 197. Traduzse) $)^{3}$ e não há dúvida que o direito participou ativamente desse processo. Ademais, por meio de ações de fomento a atividades econômicas e de organização dos fatores produtivos, incluindo o trabalho, influencia até mesmo o contexto socioeconômico.

Considerando a relevância desse fator, julga-se possível considerá-lo uma causa adequada para compreender os padrões específicos de ação sindical desenvolvidos em cada

\footnotetext{
${ }^{3}$ No original: "In the end, it is the political context as much as the steam-engine, which had most influence upon the shaping consciousness and institutions of the working class” (THOMPSON, 1966, p. 197).
} 
nação. Desse modo, o objeto deste estudo é a análise do impacto do aparato de regulação jurídica e institucional das relações de trabalho sobre a performance da ação coletiva dos trabalhadores em dois contextos sociais e institucionais distintos: o Brasil e a GrãBretanha.

O modelo aqui desenvolvido para analisar essa relação supõe que regimes distintos de regulação jurídica das relações de trabalho são o produto, como no geral o são as políticas de intervenção social, de histórias nacionais, forças sociopolíticas e arranjos institucionais particulares, bem como de políticas anteriores (SKOCPOL, 1985; WEIR; ORLOFF; SKOCPOL, 1988). Ademais, considera que as distinções na forma de regular as relações de trabalho seriam responsáveis pela conformação de padrões de ação sindical singulares. Por essa razão, cumpre investigar a dinâmica histórica de formação e desenvolvimento desses modelos para compreender como adquiriram as atuais características e de que modo interferiram nas possibilidades de ação organizada dos trabalhadores. Para tanto, emprega uma perspectiva comparativa histórica, reconstruindo os processos de montagem de dois aparatos bastante distintos de regulação das relações de trabalho e comparando seus efeitos.

Essa perspectiva considera que, não obstante a singularidade histórica dos modelos de regulação do trabalho, é possível compará-los em função do volume e natureza da regulação do trabalho. De acordo com esse critério, os regimes podem ser identificados, para fins analíticos, em um contínuo que vai da menor intervenção do Estado nas relações de trabalho e maior margem de livre negociação entre empregados e empregadores, até a ampla intervenção do Estado no sentido de coordenar a gestão das relações de trabalho e subsumi-las, completamente, a normas ou acordos por ele patrocinados. A escolha da GrãBretanha como contraponto ao Brasil deve-se ao fato de que seu modelo de regulação das relações de trabalho pode ser classificado no extremo oposto desse contínuo: a GrãBretanha corresponde à primeira extremidade, com um modelo pluralista de intermediação dos interesses do trabalho com limitada participação do direito, e o Brasil à segunda extremidade, com um modelo corporativista, em que o Estado coordena canais de interlocução entre os atores e regula amplamente as relações de trabalho.

Os dois termos da equação que conformam a relação aqui investigada são o (1) aparato de regulação jurídica das relações de trabalho e (2) a performance da ação sindical. Para verificar empiricamente essa relação é necessário compreender o sentido de seus termos, de modo a determinar o objeto a ser analisado. Por aparato de regulação jurídica 
das relações de trabalho entende-se as normas jurídicas de organização jurídica da disposição do fator de produção trabalho e das relações engendradas na produção, em torno da comercialização da força de trabalho. A regulação jurídica do trabalho ocupa o âmago dos esforços de ordenação e promoção dos processos de acumulação, que exigem a normalização, legitimação e administração dos conflitos relacionados à relação salarial, finalidades próprias dessa regulação. Aparatos de regulação do trabalho são corpos de normas jurídicas e instituições que disciplinam essas relações, socializando os atores nas práticas de trabalho e nas regras do mercado, bem como administrando os conflitos que emergem na relação de trabalho.

Entre os elementos comumente incluídos em um sistema de regulação das relações de trabalho, estão os direitos básicos dos empregadores, empregados e suas organizações. A regulação das organizações inclui os direitos de associação, de reconhecimento, de consulta, informação e participação em decisões da empresa, formas de interlocução e negociação, assim como de suspensão do contrato de trabalho como forma de expressão de demandas. As regras de barganha e negociação coletiva influenciam, quando não determinam o nível, cobertura e escopo das negociações e acordos. Incluem, ainda, disposições referentes à resolução de conflitos que possam emergir e previsões sobre o emprego de métodos como conciliação, mediação e arbitragem. Por fim, a regulação do trabalho pode determinar os termos da compra e venda da força de trabalho, incluindo disposições a respeito dos salários, bem como diretrizes sobre períodos em que o trabalho é executado (HOWELL, 2007, p. 42-3)

A regulação jurídica das relações de trabalho é fenômeno que integra um movimento mais amplo de intervenção do Estado na sociedade e cuja finalidade precípua é assegurar a formação, reprodução e regulação social da força de trabalho. O caráter especial desse aparato de regulação, que o distingue da regulação de outras relações entre indivíduos é justamente sua relevância para a sobrevivência da sociedade, diante do moinho satânico do mercado (POLANYI, 2000). O reconhecimento da necessidade de regular socialmente o trabalho é o produto lógico da percepção das insuficiências e inadequações dos mecanismos de mercado para explicar a formação da relação de trabalho assalariado e sua reprodução. Como argumenta Polanyi (2000), o trabalho é uma mercadoria apenas fictícia, cujo intercâmbio corresponde a uma relação singular e socialmente arraigada: a oferta de trabalho no mercado não é regulada apenas pela demanda ou pelo salário e a relação de trabalho não envolve a aquisição do trabalhador, 
seu ser ou corpo, mas suas capacidades intelectuais, físicas e emocionais de realizar trabalho e reproduzir capital. Desse modo, a relação é complexa e requer um intercâmbio constante, demandando do trabalhador um permanente estado de prontidão para utilizar sua força de trabalho para realizar tarefas específicas, em ritmo determinado, em cada etapa da produção (PECK, 1996, cap.2).

Dentre as funções exercidas pelo aparato de intervenção social do Estado que se materializam por meio da regulação jurídica das relações de trabalho destacam-se a produção e a reprodução do trabalho. A primeira é necessária porque o trabalho não se apresenta naturalmente no mercado (OFFE; LENHARDT, 1990, p. 78). A produção e oferta do trabalho no mercado dependem da reprodução humana, mas também de políticas estatais, processos de socialização e de estruturas familiares que constroem relações de dependência salarial. Para compelir a classe despossuída a oferecer sua força de trabalho no mercado, transformando-a em trabalho assalariado, o Estado emprega a política social (OFFE; LENHARDT, 1990), oferecendo um sistema de garantias e proteções contra os riscos sociais representados pelo assalariamento e não cobertos pelo mercado (CARDOSO JR; JACCOUD, 2005, p. 186). Mas, uma vez incluída no mercado, é necessário assegurar a reprodução da força de trabalho e prevenir a aniquilação dos trabalhadores na relação de emprego. Para tanto, o aparato de regulação jurídica das relações do trabalho estabelece limites à exploração do trabalho, condições para preservar a saúde física e mental dos trabalhadores e programas suplementando sua renda para garantir suas condições de subsistência (OFFE; LENHARDT, 1990, p. 83).

Dessa forma, além das normas e instituições voltadas especificamente à disciplina da relação salarial, o Estado ainda dispõe de outros instrumentos regulatórios que incidem sobre o trabalho. A política social, definindo benefícios pecuniários e serviços essenciais para fazer frente aos custos de reprodução social, é apenas uma esfera de regulação estatal que interfere nas condições de trabalho. Também a política macroeconômica afeta as condições de trabalho e emprego, bem como as possibilidades e formas de ação coletiva dos trabalhadores. A taxa de lucro e os níveis de concorrência, variáveis que podem ser influenciadas por políticas econômicas, têm um profundo impacto no equilíbrio de forças dos atores envolvidos na relação de trabalho. Arranjos oligopolistas representam ganhos no poder de barganha dos trabalhadores, pois garantem taxas mais elevadas de lucro que podem ser negociadas e a interrupção da produção tem conseqüências mais graves à economia, tornando-se um risco a ser evitado com concessões permanentes. Ademais, 
contextos de concentração do capital facilitam a coordenação dos trabalhadores e desses com seus empregadores. Políticas de controle fiscal, a seu turno, freqüentemente incluem diretrizes salariais para contornar os efeitos de aumentos de renda sobre a inflação. Essas políticas podem incluir, portanto, sérias restrições a pretensões salariais, ou podem conferir benefícios para promover a moderação das demandas. Contudo, quer se adote uma política de repressão, quer se opte por um concerto com as organizações representativas dos trabalhadores, os efeitos sobre sua atuação são evidentes.

Embora esta pesquisa considere o aparato de regulação jurídica das relações de trabalho inserido nesse programa mais amplo de intervenção na questão social e na economia, seu objeto recomenda um enfoque mais preciso. Considerando que se pretende compreender os efeitos do aparato de regulação jurídica das relações do trabalho sobre a ação sindical, a investigação está centrada nos elementos desse aparato que dizem respeito às condições de expressão de conflitos e interesses do trabalho, por meio de agremiações sindicais. Por assim ser, ao analisar os aparatos de regulação jurídica especial ênfase é conferida às normas que disciplinam a criação, organização, financiamento e atividades dos sindicatos, as regras e procedimentos de administração de conflitos envolvendo interesses do trabalho, os dispositivos que regulamentam o exercício de greve e as modalidades e unidades de negociação coletiva e, mais genericamente, os padrões normativos de execução do contrato de trabalho, que definem o espaço negocial deixado às partes na definição das condições de trabalho. O modelo de intervenção social é considerado ao longo da pesquisa apenas na medida em que produz demandas entre os trabalhadores e interfere na organização dos sindicatos.

Por desempenho da ação sindical, por sua vez, entende-se a capacidade que os sindicatos possuem de agir de modo autônomo na defesa dos interesses de seus representados e conquistar as pretensões próprias do movimento operário, tais como direitos de associação, benefícios sociais, melhores condições de trabalho e maior participação nos lucros produzidos. Para avaliar o desempenho da ação sindical, deve-se atentar para a força que os sindicatos possuem. Há três indicadores quantitativos comumente empregados em pesquisas sobre sindicatos, mas nenhum deles parece ser adequado para o presente estudo, especialmente no que se refere à análise do caso brasileiro. A filiação sindical, que indica o número absoluto de filiados ao sindicato, parece ser pouco útil para descrever a realidade brasileira diante de caracteres particulares da estrutura sindical, de acordo com a qual a base de representação dos sindicatos não se 
limita aos associados, mas abrange toda a categoria. Essa característica gera uma confusão em torno do conceito de filiação, que no Brasil não denota, como em outras partes do mundo, o número de representados pelo sindicato. Além disso, o conceito apresenta problemas mesmo em outros contextos, já que um grande número absoluto de filiados não indica necessariamente uma expressiva participação relativa dos sindicalizados no total da população assalariada. O número de filiados pode até aumentar sem representar um incremento na participação relativa dos sindicalizados se o número de assalariados aumentar em ritmo mais acelerado (CARDOSO, A. M., 2001).

Esse problema é solucionado pelo segundo indicador: a densidade sindical, que indica a parcela da força de trabalho associada a sindicatos e, portanto, a capacidade dos sindicatos de atrair sua base (GOLDEN; WALLERSTEIN; LANGE, 2005, p. 198) ${ }^{4}$. Entretanto, a filiação e a densidade sindicais apresentam em comum a falha de nem sempre indicar a capacidade para mobilizar trabalhadores ou a disposição para a ação coletiva (CARDOSO, A. M., 2001). Por óbvio que o número de membros e a densidade sindical são indicadores da capacidade de mobilização dos sindicatos. Bases extensas de trabalhadores associados aumentam o poder relativo dos sindicatos em barganhas, a capacidade de pressionar empregadores e governos e também o alcance e o impacto das decisões tomadas por lideranças sindicais, especialmente aquelas que envolvem a aplicação de sanções contra empregadores (VISSER, 1992). Aliás, “somente em algumas situações incomuns [...]”, afirmam Golden, Wallerstein e Lange (2005, p. 198), “[...] a densidade é um indicador irrelevante da habilidade do trabalho organizado atrair o suporte de massas e de seu potencial de mobilização para greves”. Contudo, a mobilização pode incluir trabalhadores não filiados e, portanto, não incluídos nos índices de filiação ou densidade sindical e estudos têm reiteradamente revelado que, de fato, não há qualquer relação entre a filiação (ou a densidade) sindical e o nível de militância. Por um lado, verifica-se um alto grau de militância em nações com reduzidos índices de filiação, como é o caso da França. Por outro, nações nas quais os sindicados controlam benefícios seletivos, tais como programas sociais, ou nas quais a lei prevê o closed shop, isto é, a associação compulsória nos locais de trabalho que reconhecem o sindicato, a filiação sindical é ampla, mas a capacidade de mobilização reduzida (VISSER, 1992, p. 23).

\footnotetext{
4 No Brasil os estudos que empregam esse indicador baseiam-se em dados obtidos pela Pesquisa Nacional por Amostra de Domicílios (PNAD), do IBGE. Para medi-la, utiliza-se a proporção de filiados sindicais no universo da população ocupada ou de assalariados.
} 
O terceiro e último indicador empregado é a cobertura sindical, que se refere ao percentual de trabalhadores que têm as condições de trabalho definidas por negociações realizadas pelo sindicato. A cobertura das negociações coletivas sindicais é empregada como indicador porque revela a influência dos sindicatos sobre as condições do trabalho e os níveis salariais e, conseqüentemente, o impacto da ação sindical sobre a performance econômica. Quanto mais ampla a cobertura dos acordos celebrados, maior é impacto dos sindicatos sobre a economia. Assim como ocorre com os índices de filiação e densidade sindical, entretanto, nem sempre a cobertura dos acordos representa o resultado real da mobilização dos sindicatos. No Brasil, por exemplo, a cobertura sindical significa pouco, pois aqui ela tende a ser absoluta, em razão da disposição legal que estende a validade das negociações sindicais a toda a categoria (CARDOSO, A. M., 2001). O mesmo ocorre, aliás, em grande parte da Europa Continental, onde embora a cobertura dos acordos sindicais continue ampla, há um decréscimo nos índices de filiação sindical (GOLDEN; WALLERSTEIN; LANGE, 2005, p. 222).

Os três indicadores são, portanto, insuficientes e inadequados para medir o desempenho da ação sindical e a força dos sindicatos. A despeito de auxiliarem na avaliação dessas condições, é necessário incluir, para avaliar a performance e a força efetiva da ação sindical, outros elementos, como aponta Visser (1992, p. 22), sem que isso represente um excessivo alargamento da noção de performance, a ponto de criar uma confusão entre o indicador e suas causas ${ }^{5}$. Um indicador abrangente da força da ação sindical deve ser capaz de traduzir o poder possuído pelas organizações operárias, compreendido como a capacidade de “impor a própria vontade, dentro de uma relação social, mesmo contra toda resistência [...]” (WEBER, 2004, p. 43. Traduz-se) ${ }^{6}$. Em outras palavras, o desempenho sindical deve ser medido em função da capacidade que os sindicatos possuem de constranger irresistivelmente os comportamentos de outros atores, aplicando sanções contra empregadores ou deixando de apoiar certos grupos políticos. Para tanto, os sindicatos devem possuir uma considerável capacidade de mobilizar trabalhadores em torno de suas demandas, o que por sua vez depende do sentimento de representação dos associados e de uma ampla penetração nos locais de trabalho (VISSER, 1992).

\footnotetext{
${ }^{5}$ O próprio Visser (1992, p. 22), criticando indicadores por demais estreitos da força sindical, sugere uma concepção por demais alargada e que, por isso mesmo confunde indicadores de força com as suas causas, criando o risco de explicações tautológicas. Dentre os elementos indicadores da força sindical que são aqui consideradas como causas, Visser inclui a composição e comprometimento dos membros, os recursos acumulados pelo sindicatos, leis de associação sindical e o papel público desempenhado pelo trabalho.

${ }^{6}$ No original: “imponer la propia voluntad dentro de una relación social, aun contra toda resistencia..." (WEBER, 2004, p. 43).
} 
Acredita-se, por tanto, que o desempenho dos sindicatos e outros movimentos organizados de trabalhadores pode ser verificado, de modo a representar o poder dessas associações, com referência à capacidade de alcançar os propósitos genericamente associados a esses movimentos e, assim, defender interesses legítimos dos trabalhadores. É certo que uma medida baseada em resultados práticos representa problemas de mensuração objetiva, mas como esta pesquisa não está fundamentada na análise comparativa de dados estatísticos, mas, pretendendo analisar historicamente a ação dos sindicatos, não se julga necessário um indicador quantificável ${ }^{7}$. Para analisar a performance dos sindicatos basta verificar em que medida os sindicatos se aproximaram de alcançar seus propósitos.

Quais são, porém, esses propósitos genéricos da ação sindical? No geral, a literatura demonstra que os sindicatos consolidaram-se, no século XX, como organizações reformistas. Nesse sentido, o instinto fundamental das organizações de trabalhadores seria não o de lutar contra a organização da produção e da propriedade em bases capitalistas (BENDIX, 1996; KORPI, 1983; MARKS, 1989; PRZEWORSKI, 1985), mas em defesa de uma maior participação nos frutos da produção, melhores condições de trabalho, direitos associados à produção e programas de proteção social que garantissem um meio de subsistência em condições de impossibilidade de comercialização da força de trabalho.

Portanto, suas lutas tinham uma clara vertente econômica, materializada nas demandas por acesso a condições materiais suficientes para a subsistência e uma participação mais justa na riqueza social, mas também uma vertente política. No passado, as organizações operárias lutaram nos países capitalistas avançados pela ampliação da cidadania política à classe trabalhadora (MARSHALL, 1992), mas a crescente abertura dos sistemas políticos à participação política permitiu à classe trabalhadora criar agremiações políticas para representar seus interesses, separando as demandas políticas dos sindicatos. Desde então, os sindicatos continuam sua luta, juntamente com os partidos da classe trabalhadora, pelo reconhecimento de seu proeminente papel social no sistema capitalista, com a aquisição de uma participação com esse consentânea, seja pela concessão da cidadania social, tornando-a titular de um conjunto de direitos e beneficiária de uma proteção social contra os riscos assumidos na produção da riqueza nacional, seja com uma parcela mais justa da riqueza nacional. Entretanto, sua participação política passa a centrarse na ampliação dos direitos associados ao mundo do trabalho e na remoção de obstáculos

\footnotetext{
${ }^{7}$ Mesmo que empregássemos a densidade sindical como único indicador da performance sindical, os resultados, como se verá ao longo do trabalho, não seriam diferentes, já que a densidade na Grã-Bretanha, embora decrescente, é ainda muito superior à brasileira.
} 
à organização e ação concertada dos trabalhadores (GEARY, 1981). Mesmo Lenin afirma, ainda que ignorando uma dimensão de afirmação identitária do operariado nas sociedades nacionais, que a luta sindical no terreno político é um instrumento para melhorar as condições de trabalho e de vida dos operários por meio de “medidas legislativas e administrativas” (1978, p. 49). Para caracterizar o caráter político da ação sindical emprega o exemplo dos sindicatos ingleses que "há muito tempo lutam pela liberdade das greves, pela supressão dos obstáculos jurídicos [...] ao movimento cooperativista e sindical, pela promulgação de leis para a proteção da mulher e da criança, pela melhoria das condições do trabalho através de uma legislação sanitária e industrial etc” (idem, p. 49). Dessa forma, a performance sindical deve ser analisada com referência à capacidade de mobilização e constrangimento de outros atores para conquistar esses propósitos econômicos e políticos.

A análise da relação entre o aparato de regulação jurídica e a performance da ação coletiva e a demonstração dos efeitos do primeiro sobre a segunda valem-se de uma análise comparativa histórica alimentada por um modelo explicativo e uma chave interpretativa próprios. O primeiro é indispensável para compreender o mecanismo pelos quais as instituições influenciam a ação coletiva e é desenvolvido a partir dos aportes do institucionalismo histórico. A segunda, relevante para determinar o sentido prático desse mecanismo, corresponde às análises de Weber a respeito do processo de racionalização da vida social.

Para verificar o significado prático da influência que os aparatos de regulação jurídica das relações de trabalho desempenham sobre a performance sindical, sugere-se compreender o movimento de construção desses aparatos como inscrito no processo de racionalização das relações sociais pelo qual passa o mundo ocidental moderno, posição já defendida no passado por analistas do sindicalismo brasileiro como Martins (1989). Na leitura de Weber (2004), esse processo manifesta-se tanto na burocratização da administração estatal, que domestica e organiza o exercício da força pelo Estado, além de garantir impessoalidade e igualdade formal nas relações sociais, quanto na construção de um direito calculável, capaz de oferecer expectativas orientadoras das ações sociais e processar de modo racional os conflitos que emergem por meio da subsunção dos casos às regras gerais e abstratas. Nas duas instâncias, o processo representa um desencantamento da vida social, por meio da remoção de elementos tradicionais, carismáticos ou emocionais das decisões que regulam a sociedade e que, por meio da racionalização passam a referir-se exclusivamente ao conjunto de regras abstratas que compõem o direito. Nesse sentido, o 
direito do trabalho pode ser compreendido como construtor de uma ordem racional e calculável que revela uma afinidade com os processos de acumulação capitalista, que exigem calculabilidade para ação. Embora exigida para orientar a ação na sociedade moderna, essa calculabilidade conferida pelo direito também limita as opções de curso de ação a serem tomadas pelos atores e as formas de manifestação de conflitos, confinando-os aos limites de uma racionalidade heterônima.

A concepção de racionalização é válida para compreender as orientações subjacentes ao processo de construção do aparato de regulação jurídica das relações de trabalho e também por que ele influencia as potencialidades de ação sindical. No entanto, o processo de racionalização nada diz sobre como operam esse aparatos, de modo a condicionar a ação sindical. Por que, a despeito de limitar as possibilidades de ação, esses aparatos são aceitos? Para responder a essa questão é necessário determinar os mecanismos práticos pelos quais a regulação jurídica e institucional condiciona os padrões de ação sindical, normalizando comportamentos dos atores por eles afetados e, assim, permitindo a reprodução de relações sociais desejadas e das próprias características essenciais do modelo. Esses mecanismos são, fundamentalmente, os mesmos pelos quais esses aparatos logram entronizar-se e reproduzir-se, resistindo à mudança.

Essa linha de investigação tem particular importância no caso brasileiro já que, como se verá, o modelo de regulação permaneceu praticamente intocado e goza do apoio de amplos setores do movimento sindical e dos trabalhadores. Diante desse cenário, ganha dimensão a pergunta: por que, a despeito de obstaculizar uma ação sindical mais combativa e ser ineficaz para a defesa dos autênticos interesses do trabalho, logra reproduzir-se com o apoio mesmo dos trabalhadores? É certo que a resposta a essa questão é trivial para os períodos autoritários da histórica brasileira, nos quais a repressão e o fechamento do sistema político eram suficientes para gerar obediência e reduzir iniciativas de mudança. A repressão exercia o efeito tradicional de elevar os custos da articulação de um movimento não alinhado aos objetivos do regime e reduzir os benefícios que podiam ser esperados com a ação (TILLY, 1978, p. 100). O aparato estatal forte e impermeável às demandas populares representava reduzidas oportunidades e ganhos com a mobilização e desencorajava a ação coletiva. A manutenção do modelo brasileiro durante os períodos democráticos, entretanto, não é explicada pela repressão ou pela falta de oportunidades no interior do sistema político, assim como tampouco é o caso britânico de reprodução prolongada de um padrão de regulação pluralista, baseado na negociação coletiva, apenas 
alterado por um programa político conservador de violento desmonte, após a recusa reiterada do sindicalismo em negociar com o governo mudanças. Logo, é necessário compreender de que modo esses modelos logram condicionar padrões particulares de ação sindical, entronizar-se e de que maneira apresentam características que os tornam resistentes a reformas intensas mesmo diante de transformações sociais e pressões econômicas.

Para tanto, propõe-se um modelo explicativo fundado teoricamente no institucionalismo histórico e, em menor medida, na teoria da estrutura das oportunidades políticas, desenvolvida para analisar movimentos sociais. Esse modelo busca explicar como o Estado, entendido tanto como estamento burocrático com orientações próprias, quanto como conjunto de instituições que estruturam a relação entre a sociedade civil e a autoridade pública (SKOCPOL, 1985, p. 21), ativa identidades coletivas determinadas, distribui poder de modo desigual para os grupos sociais, limita as opções e condiciona as estratégias de ação coletiva. O modelo aponta que mesmo os processos de mudança política obedecem a padrões próprios e reproduzem características singulares e arraigadas das instituições em mudança, ao contar com a influência de burocracias e clientelas fiéis, que gozam de espaços privilegiados nos âmbitos de formulação de políticas públicas e obstaculizam reformas intensas. No caso britânico, por exemplo, a ausência de normas cristalizadas e instituições permanentes de gestão das relações de trabalho no interior do Estado explica a maior facilidade com que governos promoveram drásticas mudanças.

\section{Causalidade adequada e o método comparativo histórico}

Uma posição pragmática recomenda que a escolha do método de pesquisa seja definida pelo objeto a ser estudado e pela perspectiva que o pesquisador possui a respeito dele. A escolha do método comparativo histórico para este estudo deriva da natureza complexa dos processos analisados, que envolvem diversos fatores e suas interações em conjunturas históricas cambiantes. O método comparativo é especialmente eficiente para compreender processos sócio-históricos de mudança e continuidade que soem ser lentos, complexos, freqüentemente dependentes de características endógenas, processos de sobredeterminação (path dependent) e apresentam efeitos de retorno incremental (RUESCHEMEYER, 2003). Esse método permite compreender fenômenos macrosociais e diferenças históricas entre grandes unidades, tais como Estados-nação, por meio do 
desenvolvimento de esquemas explicativos de natureza holística, envolvendo uma grande quantidade de variáveis (RAGIN, 1987, p. 6).

Com efeito, o propósito deste trabalho é comparar dois modelos de regulação jurídica das relações de trabalho para determinar como influenciaram na performance da ação sindical. Considerando-se que esses fenômenos são fruto de dinâmicas históricas particulares, ganha relevo a proposta comparativa histórica, que permite reconstruir todo o processo de formação dos modelos de regulação jurídica nas duas nações escolhidas e ressaltar as características mais influentes sobre a ação sindical. Atentando aos caracteres e circunstâncias históricas particulares, o método permite explicar as causas das diferenças verificadas na ação sindical nos dois contextos.

O simples emprego do método não soluciona, contudo, o problema fartamente discutido nas ciências sociais de realizar inferências causais a partir de um pequeno número de casos analisados. Neste estudo, é necessário comprovar de algum modo a relação causal entre aparatos de regulação jurídica e padrões de ação sindical. Para solucionar essa questão, alguns teóricos do método comparativo histórico (SKOCPOL, 1979) defendem a aplicação dos cânones da indução experimental de Stuart Mill, que permitiriam gerar inferências causais a partir da análise de poucos $\operatorname{casos}^{8}$. A proposta de Mill é baseada no emprego dos métodos da concordância e da diferença e pressupõem o tratamento da pesquisa como um experimento natural gerando proposições determinísticas sobre a co-variação entre causa e conseqüência (GOLDTHORPE, 2000, p. 48). Na prática, verificam-se quais os elementos estavam presentes (método da concordância) ou ausentes (método da diferença) quando uma conseqüência foi verificada. Os fatores que variaram nos casos em que também houve variação em uma condição histórica (conseqüência) são considerados causas determinantes.

Esse método possui, contudo, uma série de limitações. A inferência causal por ele produzida sugere uma relação invariável, monocausal e baseada em informações precisas (LIEBERSON, 1991, p. 307). O método de Mill produz uma proposição determinística, de acordo com a qual sempre que os fatores causais variarem, haverá (ou não) uma variação em um fenômeno (conseqüência). Contudo, os fenômenos sociais são produto de múltiplas causas e de sua interação dinâmica em contextos sociais distintos. Com efeito, eles são excessivamente complexos para admitir explicações monocausais ou determinísticas (GOLDTHORPE, 2000, p. 48). Não existe um único conjunto de condições necessárias e

\footnotetext{
${ }^{8}$ Antes dela, Durkheim já defendera o método de Mill como forma privilegiada de explicação sociológica. Para o sociólogo, a observação de “variações concomitantes” permitiria fazer inferências causais.
} 
suficientes que produza produtos determinados. O mesmo resultado é muitas vezes produzido por diferentes combinações e variados graus de interação entre causas (GOLDSTONE, 2003). Ademais, os esquemas explicativos não são capazes de incluir todas as variáveis possivelmente relevantes e há, freqüentemente, fatores externos à análise que também interagem com as variáveis consideradas em circunstâncias históricas particulares.

Como, então, atribuir um efeito concreto a uma causa, se "uma infinidade de fatores causais condicionaram a ocorrência do evento” (WEBER, 1949, p. 169)? Recolocando a questão nos termos concretos que interessam a esta pesquisa: como inferir conseqüências para a ação sindical a partir do modelo de regulação jurídica das relações de trabalho, em meio a um universo de fatores condicionantes? A sugestão que Weber oferece para esse problema da avaliação da significância causal de um fator, presente em qualquer investigação a respeito das causas históricas de um evento, é proceder a um julgamento da possibilidade objetiva, assim descrito pelo autor:

\begin{abstract}
A avaliação da significância causal de um fato histórico deve começar com a formulação da seguinte questão: na hipótese de exclusão desse fato do complexo de fatores que são considerados como co-determinantes, ou na hipótese de sua modificação em uma certa direção, poderia o curso dos eventos, de acordo com regras empíricas gerais, haver tomado uma direção de qualquer modo diferente em qualquer característica que seria decisiva para nosso interesse? (WEBER, 1949, p. 180. Traduz-se) ${ }^{9}$.
\end{abstract}

O exame da possibilidade objetiva consiste, portanto, em se questionar se um produto histórico distinto seria possível se a circunstância que se reputa causa também fosse diferente ou não estivesse presente. Se assim for, pode-se apontar que o fator é causa adequada para explicar o fenômeno. Para Weber, não há como determinar se uma causa é necessária ou suficiente, dada a complexidade dos fenômenos sociais. A causa, sugere, deve ser tratada como uma causa adequada ${ }^{10}$ para a explicação de uma variação histórica,

\footnotetext{
${ }^{9}$ No original: "The assessment of the causal significance of an historical fact will begin with the posing of the following question: in the event of the exclusion of that fact from the complex of the factors which are taken into account as co-determinants, or in the event of its modification in a certain direction, could the course of events, in accordance with general empirical rules, have taken a direction in any way different in any features which would be decisive for our interest?” (WEBER, 1949, p. 180).

10 Curiosamente, Weber comenta que o debate em torno dos critérios para se determinar relações de causalidade adequada e, no geral, em torno da possibilidade de inferências causais associadas a fatos históricos fora alimentado por juristas e, em especial, aqueles que se dedicaram ao campo do direito penal. Contudo, esses juristas enfrentavam o problema da relação de causalidade para solucionar a questão da imputação, problema distinto daquele enfrentado pelos cientistas sociais. No Direito, afirmava Weber (1949, p. 168-9), tendo em mente a responsabilidade subjetiva, ainda predominante no momento da análise, o nexo causal não é suficiente e o debate sobre as inferências causais para a responsabilização ocupava-se ainda de
} 
idéia que traduz uma relação de mera plausibilidade de um elemento haver provocado a ocorrência de um evento. Utilizando a ilustração oferecida pelo próprio Weber, empregar a Batalha de Maratona como causa adequada do desenvolvimento de uma cultura européia com traços helênicos não é o mesmo que afirmar que uma vitória persa nessa batalha teria, necessariamente, determinado rumos diferentes para o desenvolvimento da Europa e da civilização ocidental, mas apenas que essa alteração seria um efeito adequado das circunstâncias diversas (WEBER, 1949, p. 185). De igual modo, há uma possibilidade objetiva de, sendo diferente o modelo de regulação das relações de trabalho no Brasil e na Grã-Bretanha, o padrão de ação sindical nesses países também fosse diverso. Não há garantias de que os rumos da ação organizada dos trabalhadores seria diferente, mas é plausível supor que assim seria, de modo que o modelo de regulação pode ser considerado uma causa adequada.

Para avaliar a pertinência da relação causal aqui apontada, ao invés de um exercício hipotético, de construção de um modelo com circunstâncias irreais, emprega-se um segundo caso onde, como se verá, a causa presente no primeiro caso (um extenso aparato de regulação jurídica que fixa o conteúdo e procedimentos da ação dos trabalhadores) não estava presente. A partir dessa diferença, analisa-se se essa situação conduziu a um resultado diverso. Reconhecendo-se que sim, tem-se uma relação de causalidade adequada. O objetivo passa a ser, então, o tradicional nos estudos comparativos históricos: explanar a relação entre aparatos de regulação jurídica do trabalho e a performance da ação sindical examinando-se as evidências empíricas relativas aos dois casos.

Empregando-se o método comparativo histórico e tratando os aparatos de regulação jurídica como causa adequada de padrões específicos de ação sindical julga-se possível alcançar conclusões válidas nos contornos da análise. Se, por um lado, o determinismo causal e esquemas universais são rejeitados e, por outro, as circunstâncias históricas são reputadas igualmente relevantes para a explicação, por óbvio que os resultados aqui presentes não constituem leis universais ou proposições nomotéticas, aplicáveis independentemente do contexto. Não obstante, generalizações históricas são objetivamente possíveis, novamente se consideramos que essas possuem uma natureza probabilística.

Nesse sentido, é possível estender os resultados validos para os casos aqui analisados, de modo plausível, empregando-se abstrações que enfatizam alguns componentes específicos desses modelos de regulação jurídica do trabalho (RAGIN, 1987,

determinar quais fatos subjetivos, relativos ao agente, possuíam significância, tais como aqueles que configuram culpa ou dolo, e deveriam ser considerados . 
p. 5). Para tanto, os caracteres fundamentais dos casos analisados devem ser empregados para formar abstrações, tipos-ideais de regulação jurídica das relações do trabalho e de organização de seus interesses. Além disso, o fator causal aqui analisado deve comprovar ser, nos dois casos, saliente para compreender o padrão de ação sindical. Se assim for, os tipos-ideais formados podem ser empregados para construir relações abstratas que constituem hipóteses a serem comprovadas por meio da análise de outros casos (RUESCHEMEYER, 2003). É plausível, embora não certo, que as relações aqui apontadas sejam também validas - também se verifiquem - em casos classificáveis nas mesmas categorias ou tipos-ideais que os casos aqui analisados.

Desse modo, empregando-se os modelos teóricos acima descritos na análise da relação estabelecida entre aparatos de regulação jurídica e a performance da ação sindical, em dois contextos históricos distintos que conformaram modelos antípodas, pode-se chegar a conclusões que extravasam a análise dos dois casos. A investigação, acredita-se, permite verificar que aparatos de regulação intensamente controladores, que fixam as condições da relação de trabalho e da expressão dos conflitos dela decorrentes, tais como o arranjo corporativo existente no Brasil, contribuem para limitar as possibilidades de ação sindical e diluir seu caráter combativo. Nesse sentido, é uma causa adequada, embora não a única, a explicar o alinhamento dos sindicatos no Brasil aos interesses do Estado nacional e o caráter geralmente pouco combativo dos movimentos organizados em torno dos interesses do trabalho. Por outro lado, aparatos de regulação do trabalho que se limitam a conferir liberdade de existência e ação aos sindicatos, deixam maior margem de negociação e contribuem para um padrão de ação sindical mais combativo. Secundariamente, o estudo da origem, desenvolvimento e consolidação de modelos regulatórios do trabalho pelo Estado pode servir de instrumento para compreender os impactos das transformações socioeconômicas nas últimas décadas do século XX sobre os sindicatos com padrões de ação próprios, e as alternativas que se colocam às entidades sindicais para manter seu poder e um papel proeminente em meio às instituições sociais.

\section{Plano do trabalho}

O primeiro capítulo apresenta os marcos teóricos que orientam a investigação. Sua primeira parte analisa os sentidos do processo de racionalização e a sua materialização na construção do aparato jurídico de regulação das relações trabalhistas. A segunda parte, por 
sua vez, apresenta um modelo explicativo para compreender o mecanismo pelo qual a regulação jurídica das relações de trabalho condiciona o padrão de ação sindical, reproduz relações desejadas e entroniza-se, criando obstáculos a reformas.

O segundo capítulo aplica esses marcos na análise da construção e desenvolvimento do aparato corporativo de regulação do trabalho no Brasil, destacando a farta produção legislativa e as medidas centralizadoras e subordinadoras dos sindicatos à máquina estatal, implementadas durante os dois períodos autoritários. Analisam-se, também, as influências desse modelo na formação de um padrão sindical pouco combativo e as razões de sua manutenção após a redemocratização.

O terceiro capítulo aplica os mesmos marcos para analisar o caso britânico, iniciando-se pela descrição do papel que a regulação jurídica desempenhou na própria formação da classe trabalhadora e das lutas em torno do direito de associação, para então passar à análise do modelo de regulação das relações de trabalho propriamente dito. São destacadas as iniciativas de racionalização do modelo na década de 1970, bem como as críticas e o posterior desmonte do modelo, culminando nas medidas de descoletivização e flexibilização das relações e, finalmente, a re-regulação promovida pelo recente governo trabalhista.

Na conclusão, são sintetizadas as principais características dos dois modelos de regulação jurídica com o intuito de proceder a uma breve comparação e verificar as influências que exerceram sobre o potencial de ação sindical. Abstraindo-se os casos analisados e enfatizando suas características determinantes, propõe-se uma formulação mais genérica a respeito dos resultados encontrados, válida para outros casos que apresentem as mesmas características e contextos históricos semelhantes. Também se busca analisar, nesse ponto, qual a capacidade desses modelos e do padrão de ação sindical por eles produzido de reagir aos desafios impostos pela flexibilização produtiva, o acréscimo de complexidade nas formas de utilizar o trabalho, os ataques políticos contra o trabalho organizado e a recobrada de poder dos empregadores de definir as condições da relação de trabalho. 


\section{Um Marco para a Análise da Regulação das Relações de Trabalho e Seus Efeitos SObre a AÇão Sindical}

Um dos pressupostos desta pesquisa, apresentado na introdução, é a consideração de que distintos aparatos de regulação do trabalho são o produto de trajetórias históricas igualmente particulares. Desse modo, as formas de regulação das relações engendradas no mercado de trabalho são o produto de práticas arraigadas dos seus agentes, reconhecidas e toleradas pelo Estado, ou de políticas produzidas por esse. Essas políticas podem refletir os interesses dos atores por elas afetados e manifestados por meio de representantes legislativos, em contextos democráticos, ou podem ser impostas por governos autoritários. De qualquer modo, embora relevantes para a compreensão da natureza desses aparatos, os processos de construção das práticas regulatórias não se confundem com seu desenvolvimento e reprodução, ou mesmo com seus mecanismos de operação. As origens do modelo definem características fundamentais, mas não explicam os seus destinos, quer em termos de eficácia, quer em termos de estabilidade. Os dois casos analisados nesta pesquisa confirmam, aliás, essa distinção fundamental entre processos de formação e operação de aparatos de regulação. De um lado, o modelo britânico oferece um exemplo de produto de processos democráticos, que gozava de grande apreço por sindicatos e pela sociedade e que, entretanto, foi significativamente reformado. De outro, o modelo brasileiro oferece um exemplo de produto autoritário e que, embora não represente os melhores interesses dos trabalhadores, sobreviveu a dois contextos democráticos com limitadas alterações.

Esses casos evidenciam, também, que a simples privação ou o sentimento de insatisfação não é suficiente para detonar ações de oposição e gerar conflitos (TARROW, 1994, p. 71), assim como a simples satisfação não garante eficácia ou estabilidade ao aparato de regulação. Logo, os sentimentos dos atores envolvidos não são suficientes para gerar ações sindicais que observam os padrões estipulados pelo aparato regulatório, ou ações que os desafiam; tampouco explicam a oposição ou adesão sistemática ao mesmo.

Considerando essas dificuldades e a complexidade do tema, busca-se aqui apresentar um modelo explicativo que seja capaz de compreender como aparatos de regulação do trabalho atingem graus de eficácia e estabilidade. Para enfrentar a primeira questão - a eficácia - é necessário compreender o mecanismo pelo qual o marco 
regulatório, suas normas e instituições orientam ações individuais de sindicatos e, desse modo, condicionam a formação de padrões específicos de ação sindical, majoritariamente obedientes aos limites fixados pelo marco regulatório. A segunda questão - a relativa estabilidade dos aparatos de regulação - exige compreender tanto quais aspectos do modelo facilitam ou obstruem reformas, como o mecanismo pelo qual os padrões de ação sindical garantem a reprodução das características fundamentais desse marco regulatório. Julga-se, portanto, que a estabilidade também é explicada pela reprodução de padrões de ação sindical consentâneos com o aparato de regulação.

Além desses pressupostos, o modelo explicativo aqui proposto assume que aparatos de regulação das relações de trabalho são tensionados por pressões da realidade social e que, por isso, estão sujeitos a oposições, mudanças e desvios em relação às intenções originais das instituições e de seus atores. Não se pode desconsiderar que tais aparatos interferem nas atividades produtivas e, por tanto, estão sujeitos a pressões oriundas de processos de transformação socioeconômica. Tampouco é possível ignorar as forças sociais que se opõem ao modelo e ações sindicais que fogem aos padrões reiterados. Contudo, ao condicionar as estratégias dos atores, o aparato institucional, as políticas e normas de regulação limitam reformas e moldam também as respostas a essas pressões.

Duas concepções teóricas orientam o modelo explicativo aqui desenvolvido, igualmente centradas nas capacidades das estruturas, políticas e atores estatais de oferecer oportunidades e constrangimentos, ou incentivos e custos, à ação coletiva. A primeira concepção é institucionalismo histórico ${ }^{11}$ que considera que o Estado, tanto por meio de burocracias com orientações próprias, quanto por meio de instituições e políticas, define as formas de expressão social dos conflitos, influenciando as opções de ação e as estratégias dos grupos sociais (SKOCPOL, 1985, p. 21), bem como os sentidos das demandas e lutas coletivas (EVANS; RUESCHEMEYER; SKOCPOL, 2002, p. 253) ${ }^{12}$. Como uma resposta

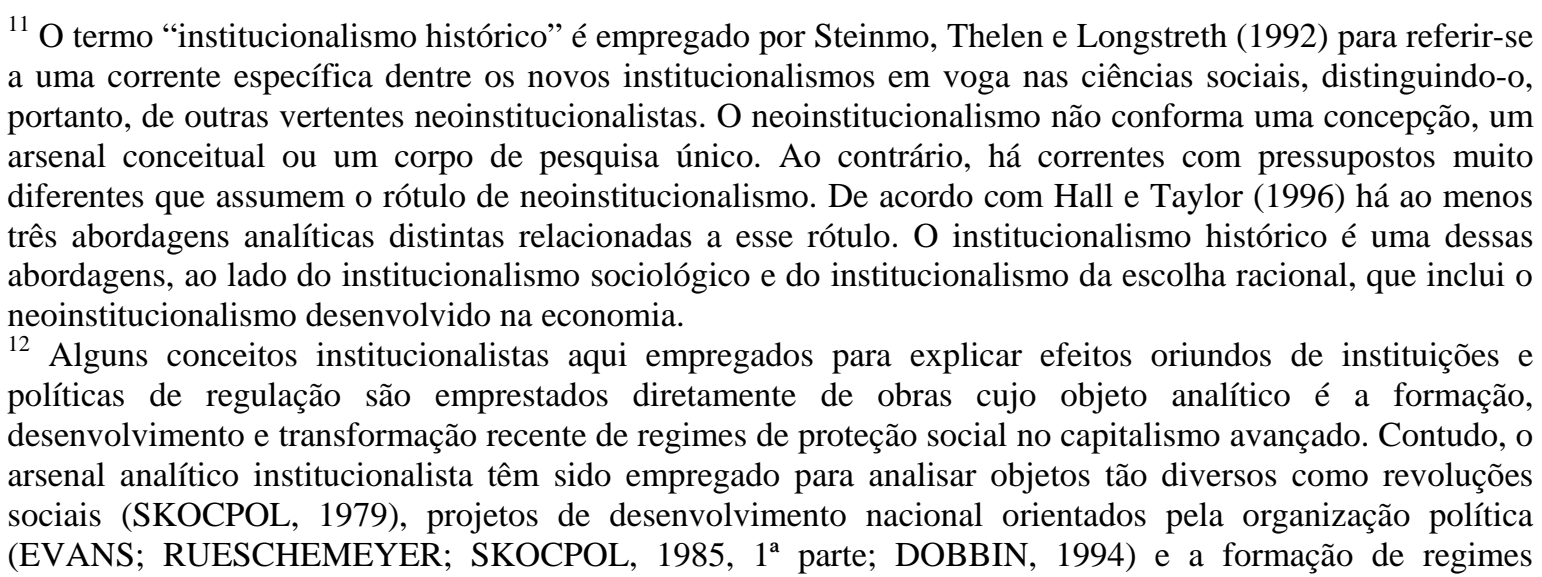


teórica ao estrutural-funcionalismo corrente na ciência política nas décadas de 1960 e 1970, a maior parte da pesquisa institucionalista histórica consiste em comparações internacionais de políticas públicas, enfatizando o impacto das instituições políticas nacionais na formação dessas políticas e na estruturação da relação entre atores relacionados, tais como legisladores, interesses organizados do trabalho e do capital e o eleitorado (HALL; TAYLOR, 1996, p. 938).

Muito embora as explicações institucionalistas incluam outros fatores, e recentemente venham conferindo amplo espaço em seus estudos ao valor de idéias e percepções construídas em torno de valores e ações políticas, a organização institucional do sistema político e da economia política é considerada o principal fator estruturante do comportamento coletivo (STEINMO; THELEN; LONGSTRETH, 1992, p. 3). Como elemento central da economia política, as instituições, procedimentos e rotinas mobilizados para regular a relação de trabalho integram esse conjunto de instituições que estruturam as relações entre atores na política, na sociedade e no mercado.

Não há uma definição única entre os institucionalistas históricos do que constitui exatamente sua unidade de análise, isto é, o que são as instituições incluídas na análise, mas Hall e Taylor oferecem uma definição ampla e que corresponde ao objeto de análise da maioria dos estudos institucionalistas, incluindo "os procedimentos formais e informais, as rotinas, normas e convenções enraizadas na estrutura organizacional do sistema político ou economia política” (1996, p. 938. Traduz-se ${ }^{13}$ ).

Os esforços analíticos dos institucionalistas históricos estão voltados para a reconstrução das trajetórias de desenvolvimento das instituições, com ênfase na natureza auto-referenciada desse processo, em virtude do modo pelo qual definições pretéritas de políticas e instituições limitam opções futuras. Ao investigar a relação entre o comportamento dos atores sociais e as instituições, suas análises enfatizam, ainda, as assimetrias de poder geradas e reproduzidas pela operação dessas mesmas instituições (idem, p. 937-8).

Também se empregam aqui concepções próprias da teoria dos movimentos sociais que se convencionou denominar estrutura das oportunidades políticas, mais especificamente aquelas desenvolvidas por Sidney Tarrow (1998). Para os teóricos que se

políticos democráticos e autoritários (RUESCHEMEYER; STEPHENS; STEPHENS, 1991). Desse modo, esses conceitos são considerados válidos e pertinentes para compreender, em perspectiva comparada e histórica, também o desenvolvimento de modelos de regulação jurídica das relações de trabalho.

${ }^{13}$ No original: "the formal or informal procedures, routines, norms and conventions embedded in the organizational structure of the polity or political economy” (PETER; HALL, 1996, p. 938). 
debruçaram sobre as oportunidades políticas, diferenças na estrutura política de Estadosnação são capazes de explicar diferenças “[...] na estrutura, extensão e sucesso de movimentos comparáveis [...]” (McADAM; McCARTHY; ZALD, 1996, p. 3. Traduz$\mathrm{se}^{14}$ ), porque o sistema político estrutura as oportunidades e constrangimentos disponíveis aos atores e condiciona, desse modo, a definição racional de estratégias de ação (idem, p. 2).

A partir de conceitos emprestados dessas duas vertentes teóricas pode-se desenvolver um modelo explicativo para enfrentar a questão aqui colocada, no qual três fatores, ao interagirem, atuam como fatores de condicionamento do comportamento dos atores e do modo como as iniciativas de oposição e reforma são processadas: as instituições e arranjos políticos criados para gerir as relações de trabalho, políticas estatais já consolidadas e as forças sociais que oferecem apoio à ação sindical. Desse modo, explicam a eficácia e a relativa estabilidade de aparatos de regulação jurídica do trabalho. Saliente-se que a regulação não é imune a pressões por mudanças e nem toda ação sindical reproduz padrões estipulados pela mudança. Contudo, ao estruturar as oportunidades da ação sindical e criar certos obstáculos à reforma, esses fatores explicam uma tendência à eficácia e à reprodução de características fundamentais dos aparatos de regulação das relações de trabalho.

\subsection{Instituições políticas}

Diversos elementos institucionais, tais como sistemas de governo, sistemas eleitorais e requisitos constitucionais para reformas são empregados pela literatura da ciência política como fatores explicativos da estabilidade ou instabilidade de regimes políticos, de políticas públicas e de comportamentos eleitorais. Como elementos que garantem maior ou menor estabilidade à organização política, esses elementos podem também explicar a eficácia e a reprodução de aparatos de regulação das relações do trabalho, assim como sua capacidade de resistir a ações que o desafiam e a iniciativas de mudança.

\footnotetext{
${ }^{14}$ No original: "in the structure, extent and success of comparable movements" (McADAM; McCARTHY; ZALD, 1996, p. 3).
} 
Institucionalistas e teóricos da estrutura das oportunidades políticas convergem ao considerar que instituições políticas são capazes de influenciar a conduta dos atores sociais, promovendo a aderência a suas regras materiais e procedimentais e, assim, a reprodução das relações consagradas por essas regras. Ao estruturar as oportunidades e estabelecer obstáculos para a ação organizada dos trabalhadores e, desse modo, adaptar as estratégias a serem perseguidas, gera-se um efeito de acomodação ao quadro institucional vigente, seja qual for sua extensão e natureza, que não apenas conforma um padrão específico de ação sindical, como também contribui para a reprodução do aparato de regulação.

Institucionalistas históricos vão além, afirmando que além de condicionar estratégias dos atores, instituições políticas, ao distribuir o poder político, determinam quais atores e interesses sociais serão considerados em seu funcionamento e em potenciais processos de reforma e quais demandas serão formuladas pelos atores, como e com que efeito (PIERSON, 2001; BONOLI, 2001; SWANK, 2001). Ademais, criam obstáculos a reformas radicais e, no campo das representações simbólicas, influenciam os sentidos da luta e os valores da cultura política dos atores coletivos (EVANS; RUESCHEMEYER; SKOCPOL, 2002, p. 254).

Resta, porém, compreender o mecanismo pelo qual as instituições incumbidas da regulação das relações de trabalho, incluindo os organismos de expressão e intermediação dos interesses do trabalho, condicionam a ação sindical e garantem sua própria reprodução. Fundamentalmente, esse condicionamento é o produto da distribuição de oportunidades, expectativas, valores e obstáculos pelas instituições. Toda manifestação traz riscos, de modo que a decisão de agir coletivamente considera as informações disponíveis a respeito dos benefícios e custos das diferentes possibilidades de ação. Por essa razão, afirma Tarrow, "pessoas racionais não atacam freqüentemente oponentes fortificados quando as oportunidades estão fechadas” (1998, p. 77. Traduz-se ${ }^{15}$ ). Um mínimo de acesso, continua o autor, é necessário.

Um dos modos de conquistar esse acesso é por meio da distribuição diferencial do poder político operada pelas instituições. A estrutura de organização do poder político cria canais para a expressão de determinados grupos, privilegiando seus interesses e conferindo recursos externos para sua mobilização, ao mesmo tempo em que ignora e desmobiliza outros grupos (SOSKICE; HALL, 2001, p. 5; TARROW, 1998, p. 77; HALL; TAYLOR,

${ }^{15}$ No original: "Rational people do not often attack well-fortified opponents when opportunities are closed;" (TARROW, 1998, p. 77). 
1996, p. 937). Por óbvio, tendo em vista seus interesses e estratégias próprios, “[...] o Estado não é igualmente acessível a todas as forças sociais, não pode ser controlado ou resistido com a mesma intensidade por todas as estratégias e não é igualmente disponível para todos os propósitos” (JESSOP; SUM, 2006, p. 98. Traduz-se ${ }^{16}$ ).

O institucionalismo histórico tem enfatizado em seus estudos o modo como as instituições distribuem poder de modo desigual ao longo dos grupos sociais. Alguns interesses ou grupos recebem acesso desproporcional ao processo de tomada de decisões políticas (HALL; TAYLOR, 1996, p. 941). Por meio do acesso privilegiado ou mesmo de instituições criadas especialmente para esses atores, a administração estatal seleciona os grupos estratégicos para seu projeto e confere-lhes status público, criando canais privilegiados de interlocução e distribuindo poder para que sejam representantes da sociedade no interior do Estado. Essas instituições têm por finalidade não apenas organizar as forças sociais e ampliar a legitimidade e adesão às ações estatais, mas também obter informações imprescindíveis para as políticas públicas (OFFE, 1981).

A criação de canais de diálogo funciona como um incentivo, na forma de recursos de poder e financeiros, à colaboração dos atores sindicais, como forma de garantir objetivos fixados pela administração estatal, vagamente a normalização dos processos de acumulação e a ordem social para ele necessária. A convocação ao diálogo social é normalmente acompanhada de um discurso que faz uso dos referentes vazios "nação" ou “povo”, aos quais se podem associar múltiplos conteúdos, para conclamar trabalho e capital a privilegiarem os interesses comuns sobre as demandas antagônicas. Historicamente, essa cooperação tinha fins mais específicos, como manter a ordem produtiva em momentos de guerra, impedir pressões inflacionárias decorrentes de pretensões salariais ou promover a cooperação dos atores envolvidos na produção em projetos nacionais de modernização.

Ao conferir poder ou abrir canais formais de interlocução de interesses para certos atores as instituições criam oportunidades, que acabam por condicionar as estratégias desses. Instituições de concerto de atores sociais financiam a manutenção de um canal de interlocução e garantem participação política para as lideranças representativas do capital e do trabalho. Em realidade, ao criar instituições de interlocução de interesses o Estado almeja também solucionar dilemas próprios da ação coletiva, que atores singulares ou grupos não logram ou desejam solucionar. Essas instituições facilitam a aproximação e

\footnotetext{
${ }^{16}$ No original: "[...] the state is not equally accessible to all social forces, cannot be controlled or resisted to
} the same extent by all strategies, and is not equally available for all purposes” (JESSOP, 2006, p. 98). 
negociação de agentes, assumindo esses custos, conferem garantias para o cumprimento dos acordos e aplicam sanções pelo descumprimento. Além disso, ao aproximar agentes, desenvolver normas formais ou informais e rotinas, instituições oferecem aos atores informações estratégicas e expectativas que orientam a ação. Fornecem oportunidades também na forma dessas informações e expectativas. Por outro lado, ao definir os mecanismos procedimentais de encaminhamento de demandas e o espectro de temas que serão tratados nesses foros, as instituições previnem outras ações e demandas, limitando as opções racionais dos atores.

Os benefícios de valer-se das instituições para canalizar demandas são, pois, muitos, assim como são os riscos de ignorar os canais abertos de interlocução. Instituições que oferecem uma estrutura permanente para a vocalização de demandas e intermediação de interesses do trabalho e do capital representam baixos custos de organização, além de oferecerem benefícios claros, ainda que possivelmente menores do que os de uma ação autônoma. A ação autônoma, a seu turno, representa custos mais elevados, assim como os riscos que representa, já que os Estados podem não reconhecê-las e, por meio do recurso aos ideais de diálogo e cooperação social, deslegitimarem-nas perante a sociedade, taxando-as de contrárias à sociedade ou aos interesses nacionais.

Um simples cálculo, portanto, tende a gerar a adesão dos sindicatos ao aparato institucional existente e a adaptação da sua ação para alcançar os melhores resultados possíveis: a ação no interior dessas instituições, de acordo com as regras de regulação, tem custos e benefícios claros. Já a ação externa e independente tem benefícios e custos incertos. Existindo instituições políticas que franqueiam o acesso e criam oportunidades de diálogo, o mais racional é aproveitá-las ao máximo e encaminhar, por esse meio, os interesses, com um custo muito baixo de organização ou mobilização, ao invés de comprometer os canais existentes e mobilizar recursos para uma ação independente. Contudo, o mais eficiente em termos de custos e benefícios nem sempre representa os melhores resultados em termos de defesa de interesses. Ao fixar procedimentos e conteúdos da regulação da relação de trabalho, as instituições limitam as possibilidades de ação nos canais oficiais.

Tarrow argumenta, nesse sentido, que condições em que instituições políticas conferem total acesso ao movimento e absorvendo-o no interior do Estado também previnem o protesto em formas mais autônomas (1998, p. 77). Sob essas condições de cooptação dos movimentos, pode-se esperar que a ação mais eficiente em termos de custos 
e benefícios será aquela que reproduz a existência do marco regulatório e os objetivos por ele fixados. O ideal para a expressão autônoma de interesses, afirma, não é nem a falta total de acesso, nem o acesso completo, mas um sistema institucional que ofereça uma abertura moderada (idem). No caso brasileiro, a absorção tem sido completa, gerando uma ação pouco combativa. No caso britânico, por sua vez, há uma transição do acesso limitado a um fechamento total das instituições estatais que compromete a ação sindical.

As oportunidades de ação sindical são também definidas pelos sinais de força ou fraqueza das instituições políticas, que integram o cálculo dos atores. As instituições transmitem informações sobre a capacidade de reagir a ações contenciosas ou que as desafiam a todo o momento, por meio do grau de estabilidade de coalizões e o potencial de aplicar sanções (TARROW, 1998). Aparatos estatais muito fortes tendem a reduzir as possibilidades de ação contenciosa, como ocorreu no Brasil, enquanto que coalizões governativas instáveis aumentam-nas, como ocorreu durante governos conservadores na década de 1960 na Grã-Bretanha.

As instituições estatais condicionam as estratégias dos atores e limitam suas opções não apenas por meio de oportunidades que orientam as ações, mas também elevando os custos de ações não consentâneas com os padrões definidos pelo aparato de regulação. A repressão é, talvez, o meio mais tradicional de elevar os custos de organização e mobilização (TILLY, 1978, p. 100; TARROW, 1998, p. 83). A supressão completa de movimentos ou o bloqueio de ações por meio do emprego da força física não é, contudo, o meio mais eficiente para orientar ações. A repressão é custosa em termos financeiros e de legitimidade política e pode criar condições de solidariedade entre setores sociais, nas quais se torna mais fácil agir contenciosamente, fora dos padrões definidos pelo aparato regulatório (TARROW, 1998, p. 84). Outra forma de obstaculizar a ação sindical é estabelecer controles diretos sobre ela, mas essa medida representa igualmente custos elevados de manutenção. Melhor, portanto, é elevar os custos da ação contenciosa por meio de incentivos a formas específicas de mobilização e o estabelecimento de sanções para os que se recusam a segui-las.

Afirmar que as instituições oferecem oportunidades e constrangimentos é o mesmo que defini-las como “uma matriz de sanções e incentivos” (SOSKICE; HALL, 2001, p. 5). Por meio dessas sanções e incentivos, estimulam uma ação no sentido pretendido e, assim, orientam comportamentos. Mas a influência das instituições políticas sobre a ação sindical e sua própria cristalização não são produto apenas da estrutura de sanções, incentivos, e de 
um cálculo de custos, oportunidades e obstáculos fornecidos pelas instituições. Instituições fornecem recursos e informações estratégicas, mas também conformam identidades, autoimagens e preferências dos atores (HALL; TAYLOR, 1996). Ainda que forneça uma estrutura para a negociação das condições de trabalho, os atores devem estar suficientemente organizados e contar com entidades capazes de representá-los no nível e na forma definidos pelas instituições. Assim, se as instituições determinarem uma estrutura de intermediação de interesses nacional e setorial, empregadores e empregados de um setor econômico em todo o país têm de se reunir e conformar entidades próprias para representálos. A identidade passa a ser, portanto, associada ao setor econômico ao que pertencem.

A identidade e auto-imagem dos atores são também moldados pelas instituições e suas normas por meio das expectativas e valores por eles produzidos. Por meio desses elementos, fornecem um esquema interpretativo para a ação e cristalizam objetivos partilhados sobre a ação sindical. Instituições são compostas de símbolos que, como mitos vivos, oferecem mapas para interpretar as ações e compreender a condição dos atores em um determinado contexto. As informações acumuladas pela memória institucional, as expectativas compartilhadas e reforçadas pelas normas institucionais e os valores produzidos conformam um repertório comum de sentido, que permite interpretar ações e orientam o curso de ação a seguir (HALL; TAYLOR, 1996). Esse aspecto cultural das instituições, ao influenciar propósitos e sentidos da ação sindical, também explica a entronização de um modelo de atuação que reforça as próprias instituições. O repertório de sentido e as identidades moldadas são elementos de difícil transformação, exigindo para tanto o fracasso das instituições em oferecer uma estrutura de negociação eficiente ou uma discrepância entre as normas institucionais e as práticas dos atores, a causa de um fenômeno externo de significativo impacto, como mudanças nos padrões de crescimento econômico.

O papel do direito é evidentemente primordial no esforço das instituições de orientar os comportamentos dos atores e garantir sua própria estabilidade. Por meio da regulação jurídica, o Estado pode estabelecer estímulos positivos e negativos. Estímulos positivos são oferecidos na forma de benefícios para que os atores sigam formas específicas de mobilização, fixadas em lei, de expectativas e sentidos atrelados a ações, bem como por meio de dispositivos axiomáticos, que também conformam os sentidos associados a ações. Estímulos negativos, por sua vez, são estabelecidos por meio da 
criação de obstáculos administrativos, exigências legais ou sanções contra ações consideradas contrárias aos interesses sociais.

A organização política, em especial o modo como o poder é distribuído entre as instituições estatais, também é um fator que explica, em condições democráticas, a maior ou menor propensão de um sistema à reforma. A estrutura de representação de interesses e administração das relações de trabalho influencia em sua própria conservação, ao definir as oportunidades que grupos sociais possuem de ter seus interesses considerados e traduzidos em resultados políticos. Elas determinam não apenas a habilidade de atores organizados bloquearem iniciativas de reforma, mas também quais os interesses imprimirão a natureza dos ajustes e reformas no aparato de regulação (SWANK, 2001; HALL, 2003).

Um sistema de representação de interesses altamente coordenado confere poder qualificado para atores sociais resistirem a pressões e mudanças. Representando organizações poderosas e extensas eles freqüentemente dominam posições chave no processo de formulação de políticas e agem como a principal força social de apoio a políticas de regulação. Conseqüentemente, não apenas detêm poderes institucionais de obstruir reformas, mas também de ameaçar governos com a retirada de apoio e o encerramento de coalizões (SOSKICE, 2003, p. 132). Obviamente, o potencial desses grupos de efetivamente bloquear reformas políticas também é condicionado por fatores que são exógenos ao sistema institucional de representação, tais como o grau de centralização, coordenação e mobilização de atores sociais, bem como o seu poder relativo, que determina a possibilidade de que sejam substituídos por outros grupos de apoio. Sistemas liberais ou plurais de representação, por sua vez, não conferem representação privilegiada a grupos que, ocupando posições de poder, se opõem à reforma dos aparatos de regulação do trabalho.

Sistemas políticos que concentram poder também centralizam a responsabilidade pelas decisões políticas e, desse modo, atuam como desincentivos a reformas (PIERSON, 2001). Por conta de efeitos de acomodação a seguir apresentados, as reformas de políticas regulatórias nem sempre contam com amplo apoio e podem ser impopulares, pelos riscos que representam. Por essa razão, reformas podem elevar custos eleitorais elevados para seus autores. Em circunstâncias de concentração de poder, esses custos são ainda maiores, porque se torna impossível compartilhar a responsabilidade pela introdução de medidas impopulares entre diversas instituições e atores. 
Contudo, não são apenas estruturas que concentram poder que representam custos mais elevados para a oposição e reformas em aparatos regulatórios. Organizações políticas com estrutura descentralizada representam um maior número de obstáculos a reformas políticas e, dessa forma, mostram-se menos abertas a mudanças. A existência de múltiplos centros de poder que possam agir como pontos de veto no interior das organizações, por exemplo, tais como governos subnacionais, um Judiciário forte e interventivo em questões políticas e câmaras legislativas de revisão oferecem maior blindagem institucional e resistência à reforma (PIERSON 2001; BONOLI 2001). Se, por um lado, estruturas descentralizadas oferecem múltiplos alvos para ataques pontuais e oferecem espaços para dissenso no interior das múltiplas instituições que podem ser ocupadas pelos grupos, por outro, reduzem o potencial transformador das intervenções sociais (TARROW, 1998, p. 81). O controle de políticas é distribuído a diversas instituições que necessitam ser convencidas e controladas.

Conseqüentemente, a influência exercida pela distribuição de poder político nas instituições sobre a estabilidade do aparato de regulação das relações de trabalho é maior nos dois extremos do contínuo de centralização e descentralização. O sistema de instituições políticas menos estável, isto é, mais propenso a reformas é aquele em que o poder é moderadamente descentralizado. Sistemas como esses oferecem obstáculos a reformas, mas menos que aqueles altamente descentralizados, com múltiplos pontos de veto. Adicionalmente, essa estrutura permite compartilhar os riscos eleitorais representados por reformas entre as instituições envolvidas.

\subsection{As políticas públicas}

Não apenas por meio de suas instituições, mas também ao editar políticas o Estado estrutura as oportunidades de ação sindical, bem como de oposição e reforma ao aparato de regulação jurídica existente. Políticas desenvolvidas pelo Estado, não necessariamente incidentes sobre as relações de trabalho, criam oportunidades novas para a manifestação dos trabalhadores, e também condicionam padrões de ação sindical. Muitas ações do Estado podem resultar, como conseqüência não-intencional, na redução dos custos ou na promoção de benefícios para a organização de empregados. Alguns sistemas de proteção social vinculados à participação no mercado de trabalho conferem aos sindicatos o controle 
e a administração dos benefícios, o que atrai um grande número de filiados. Nesse caso, os sindicatos atrelados à administração previdenciária desenvolvem um padrão de ação pouco divergente das políticas estatais, pois a oposição pode representar a perda do incentivo oferecido à filiação. Políticas de desenvolvimento ou recuperação econômica também apresentam efeitos sobre a associação operária. Enquanto que em alguns países da Europa, as políticas adotadas após a crise de 1929 promoveram a disciplina de trabalhadores temerosos de que a grave recessão pudesse tomar seus empregos, em outras nações, as políticas de recuperação da crise expandiram os recursos dos sindicatos, que receberam benefícios em contrapartida à sua colaboração (TARROW, 1998, p. 73). No Brasil, os surtos de industrialização geograficamente concentrados, promovidos pela política econômica do Estado, não apenas foram essenciais para a formação do operário em classe, como também facilitaram a organização sindical (STEPAN, 2002, p. 333).

As políticas, assim como o quadro geral de instituições do Estado, influenciam a formação da identidade, assim como os métodos e sentidos da ação coletiva (EVANS; RUESCHEMEYER, SKOCPOL, 2002, p. 253-4). Políticas provêm, como as instituições, incentivos e sanções que condicionam o comportamento dos atores. Ao traduzir demandas sociais, as políticas também alteram os repertórios de luta, isto é, o significado da experiência compartilhada pelos atores organizados e de seus interesses (ALONSO, 2000, p. 42-3) ${ }^{17}$. Pautas incorporadas e transformadas em políticas deixam de integrar os programas dos movimentos sociais e promovem o sentimento de que o Estado está levando em consideração os pleitos de seus membros, amortecendo sentimentos oposicionistas. Políticas podem, também, criar insatisfações e demandas, de igual modo modificando o repertório da ação coletiva e até criar novos movimentos. Dois casos ilustram como essa influência opera na prática. Geary (1981) aponta como um fator de desradicalização e arrefecimento do conteúdo político da luta operária na Europa dos séculos XIX e XX a expansão dos direitos políticos à classe trabalhadora. A política de ampliação da participação política operou uma cisão entre movimentos políticos (partidos operários) e econômicos (sindicatos) que, embora com vínculos, desenvolveram repertórios e métodos

\footnotetext{
${ }^{17}$ Alonso (2000) emprega esse argumento (de que repertórios de lutas são definidos pelas políticas estatais) em para analisar um caso distante deste trabalho, mas a lógica não era distinta. A autora aponta que ao promover reformas modernizantes na economia e sociedade, adotando bandeiras próprias dos liberais, o gabinete do Visconde de Rio Branco (1871-75) desestabilizou as organizações políticas e, em especial, a oposição liberal, que viu suas principais pretensões incorporadas no programa de governo e, em decorrência, tendeu a radicalizar-se. As lutas tornaram-se, então, contra os pilares do regime: a monarquia e a escravidão. Além disso, o movimento criou oportunidade para o surgimento de novos movimentos até então marginalizados (ALONSO 2000, p. 42-3).
} 
de luta próprios. No Brasil, por sua vez, em meio a situações de grave desabastecimento e carestia resultantes de práticas comerciais para manter preços elevados, sindicatos intensificavam suas lutas por incrementos salariais e por uma maior intervenção regulatória sobre as atividades econômicas. Essas demandas foram, porém, abandonadas, e os ciclos de conflitos encerrados quando políticas estatais de regulação de preços e salários.

Entretanto, são as políticas especificamente direcionadas à gestão das relações de trabalho que condicionam mais diretamente as oportunidades de ação sindical. As políticas de regulação especificamente orientadas à organização dos interesses do trabalho condicionam a formação das identidades coletivas. Ao definir unidades de representação e interlocução, subsume os atores a essas unidades, às quais se associa a identidade do trabalhador. Por meio desse processo, define o grau de concentração ou fragmentação do movimento sindical. No Brasil, no qual o aparato de regulação opera um enquadramento dos sindicatos a profissões definidas por lei e confere o monopólio da representação em cada localidade a um único sindicato, as identidades coletivas tendem a confundir-se com identidades profissionais locais. Desse modo, o modelo fragmenta a ação profissional e geograficamente (STEPAN, 2002, p. 317).

Ademais, as políticas de regulação condicionam a ação social e promovem a estabilidade do modelo regulatório por meio de processos de causalidade interna. Como Pierson (2001, p. 414) e Wood (2001, p. 371) argumentam, políticas complexas são desenvolvidas por meio de processos path-dependent, isto é, dependentes da trajetória, nos quais escolhas políticas iniciais limitam as opções de decisões futuras, incluindo as possibilidades de reforma e substituição do caminho adotado. Novas políticas de regulação social, os autores asseveram, exigem recursos financeiros e organizacionais, além da geração de um conhecimento específico para implementar e administrar os programas por elas criados. Por um lado, custos de implementação, coordenação e desenvolvimento do conhecimento apropriado para administrar políticas de regulação atuam como desincentivos a reformas políticas. Por outro, o desenvolvimento de políticas de modo estável e coerente geram resultados positivos e incrementais, tais como efeitos de aprendizado e coordenação, que igualmente influenciam decisões políticas futuras, tornando mais atraente manter os rumos da política.

As instituições criadas para a implementação dessas políticas representam custos elevados, assim como a edição e aprovação de seus marcos legais e as medidas criadas para garantir o respeito a elas. Ademais, como os custos mais expressivos de 
implementação de políticas são os instalação (set-up costs), isto é, os investimentos iniciais para criar as instituições e colocá-las em funcionamento, os custos marginais do desenvolvimento da política tendem a ser decrescentes, ou ao menos menores do que o custo para criar novas políticas. A natureza complexa de políticas de regulação do trabalho também demanda ações de coordenação entre órgãos governamentais, empregadores e empregados, difíceis e custosas. Importante ressaltar que os custos de coordenação estendem-se por todos os atores envolvidos nessas políticas, incluindo sindicatos de trabalhadores e empresários que têm de adaptar-se às novas regras para cumprir obrigações para ou obter direitos estabelecidos pela política. Finalmente, a implementação de novas políticas demanda conhecimento operacional. O custo de treinamento de burocracias e dos atores privados que com elas dialogam é, como os demais custos iniciais, elevado. À medida que as políticas estabilizam-se, porém, a administração contínua das políticas gera efeitos de aprendizado, tais como economias de eficiência e inovações operacionais (WOOD, 2001).

Além dos custos associados às escolhas iniciais de políticas e os resultados positives que advêm dos investimentos iniciais, a natureza auto-referenciada ou pathdependent do desenvolvimento de políticas como a de regulação das relações de trabalho está relacionada também às expectativas que essas políticas criam nos atores envolvidos e no restante da sociedade. Uma vez implementada a política, atores sociais adaptam suas expectativas de acordo com o funcionamento atual da política e os efeitos por ela gerados. A literatura denomina esse fenômeno de "expectativas adaptativas" (WOOD, 2001; PIERSON, 2001). Trata-se de um produto das políticas semelhante ao já efeito de condicionamento de estratégias provocado pelo funcionamento das instituições políticas de regulação do trabalho. Políticas criam expectativas, a partir das quais os atores envolvidos contraem obrigações e calculam os benefícios que essas oferecem.

Os efeitos produzidos pela natureza autodependente (path-dependent) das políticas de regulação não impedem manifestações de oposição, contrárias ao modelo ou previnem reformas. Mesmo Wood, quem desenvolve o argumento de que custos menores e incentivos maiores associados à permanência de políticas desestimulam reformas, admite que, em certas circunstâncias, "reformadores podem também ser capazes de explorar a opacidade da política para ocultar, atrasar, ou distribuir os custos da mudança” (WOOD, 
2001, p. 374. Traduz-se ${ }^{18}$ ). Não obstante, o desenvolvimento e as transformações da política tendem a circunscrever-se às opções deixadas por opções passadas (PIERSON, 2001, p. 415). Os custos de implementação, aprendizado, e coordenação são barreiras à reforma que, juntamente com as expectativas adaptativas, influem nos interesses dos atores, proporcionando incentives incrementais para manter as características fundamentais da política de regulação das relações de trabalho. Como resultado, os atores afetados por essas políticas tornam-se forças de apoio à manutenção das políticas e de seus efeitos e opositores de reformas (WOOD, 2001, p. 375). Dessa forma, pode-se argumentar que um dos elementos explicando a relativa estabilidade de políticas de regulação do trabalho são efeitos de acomodação que advém delas próprias, em um processo de causalidade interna ou auto-reprodução.

As políticas de regulação não apenas calibram expectativas sociais, mas também criam valores hegemônicos a respeito das funções e modos de atuação dos sindicatos, que se tornam enraizados no imaginário social após décadas de estabilidade do modelo. Aparatos de regulação, por meio de suas políticas, normas e instituições, assim como os padrões de ação sindical por elas conformados, cingem uma série de valores a respeito dos objetivos dos sindicatos e modelos de ação sindical bem sucedida. Uma regulação extensiva sobre a ação sindical, que deixe uma pequena margem de ação pode servir para consagrar os sindicatos como entidades de prestação de serviços assistenciais. Por outro lado, uma regulação mais permissiva, que permita a formação de uma tradição de sindicalismo militante pode conformar um imaginário de sindicalismo militante e engajado em demandas substantivas sobre política salarial e direitos.

Valores hegemônicos particulares possuem ainda um importante papel na orientação das preferências das forças sociais durante processos de reformas políticas, como enfatizado, para explicar trajetórias de reforma de políticas sociais, por EspingAndersen (1999) e Stephens, Huber e Ray (2003). O caso da ação sindical não é exceção: valores conformados pela reiteração de padrões de ação sindical e pela manutenção de modelos de regulação das relações de trabalho, são mobilizados sempre que uma iniciativa de reforma, para ampliá-lo, para reduzi-lo ou alterar-lhe a natureza, é apresentada. Regimes mais liberais de regulação produzem opiniões desfavoráveis a iniciativas de ampliação da regulação, seja pelos custos aos agentes econômicos, seja pela limitação da liberdade

\footnotetext{
${ }^{18}$ No original: "reformers may also be able to exploit the opacity of politics to hide, delay, or distribute the costs of change"
} 
negocial, enquanto que regimes mais extensos geram reticências sobre a flexibilização e ampliação dos espaços de livre negociação.

\subsection{Forças sociais de apoio aos sindicatos e ao aparato de regulação}

Instituições e políticas regulatórias não estão imunes a forças sociais que a elas se opõem ou promovem ações sindicais à sua margem. Porém, há também forças que são favoráveis à observância, pelos sindicatos, dos padrões definidos pelo marco regulatório e que defendem sua manutenção. A despeito de nem sempre representar os melhores e mais autênticos interesses da classe trabalhadora, o apoio dessa aos aparatos de regulação jurídica e mesmo aos padrões consolidados de ação sindical que são conformados a partir daqueles não pode ser desprezado. Pode ser racional aos sindicatos obedecer aos padrões de expressão de conflitos estabelecidos pelo modelo de regulação e, como já afirmado, envolverem-se em canais de diálogo estabelecidos pelo governo (REGINI, 1984). Calculando que os benefícios a serem extraídos das ações, e os custos em que incorrerão, são menores ao observarem os limites e padrões estabelecidos pelo modelo, os sindicatos podem optar por fazê-lo. De igual modo, a sociedade, especialmente os trabalhadores organizados, podem julgar esse padrão mais benéfico e preferir reproduzi-lo às incertezas de uma ação inovadora ou de reformas no modelo.

Assim como explica a reprodução de padrões de ação sindical e a manutenção de aparatos de regulação, o grau de apoio da sociedade às demandas dos trabalhadores também interfere na sua capacidade de tomar rumos de ação diversos daqueles previstos pelo aparato de regulação e propor reformas a ele. A capacidade que os sindicatos possuem de mobilizar a sociedade para além de seus filiados e obter recursos estratégicos determina o potencial de aplicar sanções contra empregadores e o Estado. Um grau mínimo de legitimidade social das lutas do operariado é indispensável para aplicar essas sanções que, normalmente, afetam toda a sociedade, ao representar a interrupção na prestação de serviços ou a redução da oferta de produtos. É esse grau de legitimidade e potencial de mobilização de apoio que explica o grande impacto das ações sindicais na França, a despeito da pequena filiação sindical (VISSER, 1992) ${ }^{19}$.

${ }^{19}$ Considerando esses requisitos, torna-se evidente que é muito mais simples promover ações moderadas, com propostas menos agressivas, que geram menos pontos de discordância e, assim, gozam de maior apoio 
Desse modo, o grau de apoio popular também é uma variável capaz de explicar a reprodução de padrões determinados de ação sindical e a manutenção de aparatos de regulação jurídica do trabalho. Em realidade, é o alinhamento das forças sociais em torno do apoio ou oposição ao marco que explica sua estabilidade e as posições sociais a respeito da ação sindical, informadas por valores, que define o apoio a ações obedientes ou desafiadoras. Situações particulares de alinhamento político de setores da sociedade criam quadros distintos de oportunidades e limites para a ação sindical e oferecem distintas possibilidades de reforma do aparato de regulação do trabalho.

Entre as infinitas possibilidades de alinhamento com diferentes resultados em termos de possibilidades de ação sindical e oposição a modelos de regulação do trabalho, vale recordar a hipótese em que há uma divisão interna nas elites. Essas divisões geram tensões na gestão do Estado que favorecem movimentos oposicionistas e oferecem oportunidades para ações mais combativas e para atrair aliados influentes, dissidentes que desejam juntar-se a movimentos de oposição ou membros do governo que buscam legitimidade social. Criam, ademais, instabilidades que reduzem as possibilidades de repressão. Esse quadro esteve presente em diversos quadros de emergência de movimentos de oposição política e auxilia a compreender a relativa liberdade com que os sindicatos da Região Metropolitana de São Paulo conseguiram articular-se e organizar uma ação combativa no final da década de 1970, com, ao menos, a anuência da elite industrial que se opunha ao governo pelo excesso de intervenção na economia e fracasso de suas políticas econômicas (STEPAN, 2002, p. 335).

Evidentemente, o apoio da sociedade e, mais especificamente, dos trabalhadores, aos padrões arraigados de ação social e ao modelo de regulação das relações de trabalho é reflexo de valores socialmente partilhados a respeito dos objetivos, tanto da regulação, quanto dos sindicatos. Entretanto, como apontado acima (1.2.1) valores não são variáveis independentes, mas produto de expectativas adaptativas geradas pela operação do aparato de regulação e por padrões arraigados de ação sindical. Apenas mediam a relação entre instituições e políticas, de um lado, e o apoio social a esse aparato e seus padrões de ação, de outro. Reflexos desses mesmos valores, as forças sociais tampouco são variáveis independentes: os níveis de apoio e oposição replicam as características do aparato regulatório e a extensão dos benefícios por ele distribuídos, assim como ocorre com relação a políticas sociais (PIERSON, 2001, p. 412).

na sociedade. A simples existência de movimentos mais radicais, aliás, atrai maior apoio aos moderados, em um fenômeno descrito por McAdam, McCarthy e Zald (1996, p. 14) como efeito do flanco radical. 
O nível de apoio a políticas de regulação e padrões de ação sindical por elas gerados também é influenciado, portanto, por essas mesmas políticas. O apoio está relacionado à extensão do grupo de beneficiários, gestores públicos das instituições e políticas regulatórias e os dependentes de ambos. Aparatos de regulação que distribuem benefícios financeiros e políticos aos sindicatos, como é o caso brasileiro, em que há fontes públicas de financiamento e canais de participação no governo, tendem a atrair forte apoio de membros dos sindicatos e diluir a oposição. O apoio das burocracias e beneficiários à manutenção também se relaciona aos efeitos de acomodação produzidos pelas políticas de regulação que oferecem incentivos aos atores para continuar operando sob o mesmo marco. Ademais, considerando a regulação do trabalho como inserida nos processos de intervenção social do Estado, pode-se considerar que o apoio não é apenas motivado por interesses próprios, já que sua legitimidade deriva também de seu reconhecimento como uma fonte de estabilidade social (PIERSON, 2001, p. 412-3).

Uma evidência a comprovar que as forças sociais não compõem uma variável independente é o fato da atração de apoio à manutenção das estruturas não exigir o mesmo esforço que a atração de aliados para sua reforma. O apoio à manutenção é mais simples de conquistar porque as expectativas de ação sindical tendem a corresponder aos padrões oferecidos pelo aparato de regulação em operação. Com relação a esse, há clareza sobre os custos da ação e os benefícios esperados. As iniciativas de reforma de políticas, por sua vez, dividem os opositores com propostas distintas. O apoio é mais diluído e, além disso, mais custoso porque reformas representam riscos e incertezas (PIERSON, 2001, p. 413).

Por fim, vale ressaltar que valores podem ser manipulados pelos Estados não apenas por meio de suas políticas, mas também por meio de discursos. De ambos os modos, administrações estatais acabam por condicionar o grau de apoio da sociedade às lutas operárias. Ao estabelecer uma retórica de cooperação para projetos nacionais, ao fazer uso de referentes como “povo” e “nação”, Estados definem a ação sindical obediente como comprometida e a independente como traidora desses objetivos "maiores”. A ação é, então, avaliada com referência aos objetivos comuns da nação. Isso foi feito tanto pelo Brasil, para anular ações externas ao aparato corporativo, consideradas subversivas e contrárias aos interesses de modernização nacional, quanto pelos governos conservadores da Grã-Bretanha para enfraquecer os sindicatos, afirmando que, com sua intransigência nas demandas salariais e as restrições que impunham na produção, representavam custos para 
toda a sociedade que os tornavam inimigos do Estado (HOWELL, 2005, p. 3; REID, 2005, p. 397).

\subsection{As interações entre os elementos: o modelo explicativo em ação}

Até o momento buscou-se demonstrar que as instituições, políticas e forças sociais, específicas de cada sociedade e sistema político, auxiliam cada qual a seu modo na garantia da eficácia e determinam o grau de estabilidade do modelo de regulação das relações de trabalho. Contudo, nenhum desses fatores determina, isoladamente, a conformação de padrões de ação sindical e a reprodução do aparato de regulação do trabalho em meio a tensões. Esses fatos são explicados apenas pela interação desses três fatores (Figura 1).

As instituições políticas organizam o acesso ao poder político, conferem oportunidades na forma de incentivos à observância das regras procedimentais e materiais do modelo de regulação, além de sanções e obstáculos a outras formas de ação sindical. Instituições também criam obstáculos à reforma do aparato de regulação e determinam a força detida por coalizões para promover ou resistir a reformas, bem como a habilidade dos governos de promover reformas. Por fim, condicionam as identidades coletivas e promovem valores a respeito da ação sindical e da regulação do trabalho que influem nas preferências das forças sociais.

Políticas anteriores provêm incentivos crescentes e expectativas sociais que influenciam burocracias gerenciadoras de programas de regulação do trabalho e os sindicatos a manter as políticas atuais. Assim como as instituições, criam oportunidades para os sindicatos e suas características orientam valores e preferências dos atores sociais. As políticas, ao incorporarem ou negligenciarem demandas formuladas pelos atores, também são capazes de alterar os repertórios da luta.

O último dos elementos, as forças sociais, quer por interesses próprios, quer por interesses altruísticos, mediam a relação entre os elementos institucionais e políticos e o produto desses na forma de observância e reprodução do aparato de regulação. O poder detido por grupos sociais para apoiar aparatos de regulação ou contestá-los é dependente, da natureza e extensão do próprio aparato, bem como dos recursos de poder que ele distribui para atores resistirem ou promoverem reformas. De acordo com as estratégias e 
preferências condicionadas pelas instituições e políticas de regulação, atores sociais esposam diferentes valores e propostas referentes aos modelos de regulação do trabalho e ação sindical. Conjuntamente, os três elementos estruturam as oportunidades da ação sindical e condicionam suas estratégias, promovendo a eficácia do modelo. O êxito desse aparato produz um padrão de ação sindical que, por sua vez, garante uma relativa estabilidade ao aparato regulatório ou, ao menos, assegura a manutenção de suas características fundamentais em processos de reforma.

Figura 1: Interação entre fatores explicando a eficácia e grau de estabilidade de aparatos de regulação das relações de trabalho

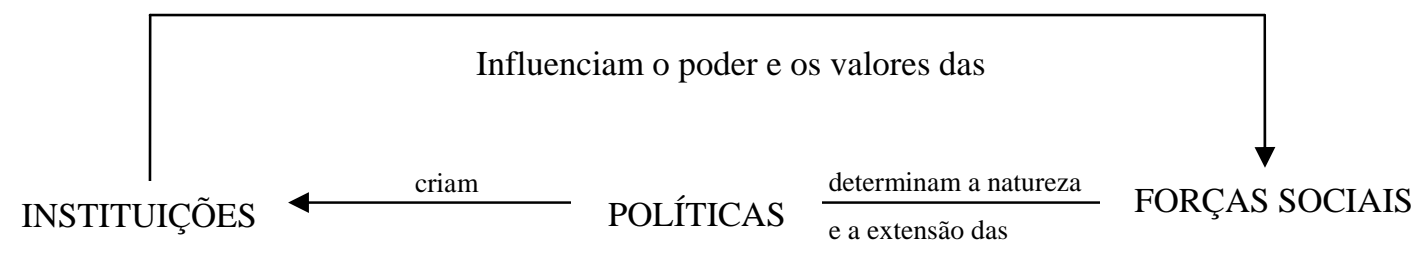

Provêm:

\section{Valores}

Valores

Incentivos à observância canais de representação de interesses

Obstáculos à expressão de dissenso e reformas

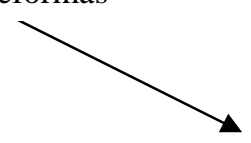

Incentivos para a manutenção de políticas de regulação

Expectativas sobre a ação sindical, que reproduz os padrões estabelecidos pela política de regulação

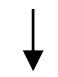

Diferentes resultados de política de regulação e ação
Apoio a políticas e instituições de regulação, bem como padrões de ação específicos 


\section{A Ordem Para o Progresso: A Regulação do trabalho no Brasil}

[...] Quais são as aspirações das massas obreiras, quais os seus interesses? E eu vos responderei: A ordem e o trabalho! Em primeiro lugar a ordem, porque na desordem nada se constrói; [...] O trabalho só se pode desenvolver em um ambiente de ordem (Getúlio Vargas). ${ }^{20}$

O presente capítulo pretende compreender de que modo o padrão específico de regulação do trabalho no Brasil, em especial no que tange à organização da estrutura de representação de interesses do trabalho, foi responsável por um esvaziamento da ação sindical e um enfraquecimento dos interesses do trabalho, prevenindo ações mais combativas.

O modelo de regulação jurídica do trabalho adotado no Brasil, fortemente inspirado no corporativismo estatista das nações conservadoras européias, apresenta particularidades resultantes de um percurso histórico próprio. A formação e a consolidação do padrão de regulação do trabalho no país deram-se ao longo de um período de duas eras autoritárias, intercaladas por um breve intervalo democrático que, embora rico em propostas de reformas, foi pouco representativo em termos de realizações no campo aqui investigado. Por essa razão, foi diminuta a participação popular na definição dos caminhos e estratégias políticas para o país, restrita a setores da elite leais e à burocracia criada pelo próprio modelo e por ele reproduzida. As iniciativas de participação e abertura ao debate, as manifestações públicas e a disputa em torno dos distintos projetos para o país foram, aliás, compreendidos pela elite e pelos governos autoritários como a própria causa do bloqueio das propostas estatais e da incapacidade governamental de promover as reformas necessárias para a promoção do projeto nacional de acumulação em bases industriais por substituição de importações.

No Brasil, ademais, o padrão de regulação do trabalho teve uma orientação clara: gerar a ordem sem a qual, acreditava-se, não seria possível o progresso das forças produtivas no país (MARTINS, 1989). O intuito primeiro era a organização do trabalho e a concessão limitada e seletiva de benefícios para a mão-de-obra dos setores mais dinâmicos e estratégicos para a acumulação em bases industriais. Desse modo, o padrão específico de regulação do trabalho poderia ser explicado à luz dos interesses, mutáveis, relacionados ao processo de acumulação e recolocação do país, em outras bases, na divisão internacional do trabalho. Desde a década de 1960, a montagem do aparato de regulação das relações de

${ }^{20}$ Apud MARTINS, 1989, p. 36. 
trabalho no Brasil tem sido relacionada a interesses específicos aos quais, por sua vez, teve de se subordinar à ação sindical. Essa abordagem evoluiu a partir da desmistificação da concepção da organização do trabalho no país como outorga de uma legislação protetiva do trabalho por Getúlio Vargas, promovida por Evaristo de Moraes Filho (1978) e passou a associar o desenvolvimento da proteção do trabalho ao projeto nacionaldesenvolvimentista (SIMÃO, 1966; PEREIRA, 1965; FAUSTO, 2000a). A despeito de sua relativa antiguidade, a recuperação dessas teses justifica-se porque as mesmas não foram questionadas e estão alicerçadas em um valioso material acumulado ao longo de diversas obras.

Alimentado por diversas ideologias - o positivismo, na Era Vargas, e a Doutrina da Segurança Nacional, no regime militar - e traduzido em diferentes projetos de acumulação capitalista no país, o padrão de regulação teria, a despeito de não ser produto de um legítimo concerto social, orientando-se para a garantia da coesão social compreendida, pelas elites, como condição sine qua non para o progresso em bases capitalistas no país. Dessa forma, mais do que o atendimento de demandas sociais, a regulação jurídica seria a resposta estatal indispensável, ainda que nem sempre funcional, para garantir a reprodução das relações de trabalho, reduzir o conflito e, assim, gerar condições para a acumulação.

A tese de que a padrão de organização e regulação do trabalho no Brasil esteve intimamente associada ao movimento de industrialização e à organização e proteção da força de trabalho necessária para esse empreendimento não é inovadora e também goza de unanimidade entre os autores que se debruçaram sobre a formação e desenvolvimento dos sindicatos no Brasil ${ }^{21}$. Os próprios atores históricos responsáveis pela formação do modelo brasileiro, como o Ministro do Trabalho Segadas Vianna, reconheceram que a intervenção social e a organização do trabalho impuseram-se no país apenas com a formação de uma base assalariada urbana, ligada ao setor industrial e porque era necessário organizar o ainda incipiente operariado para cooperar com o projeto nacional (1953). É apenas quando os interesses do Estado voltam-se para a indústria que esse começa a se ocupar das condições em que operavam as relações de trabalho e de regulá-las (MARTINS, 1989, p. 25$)^{22}$.

Aqui, além de adotar essas análises, pretende-se reconstruir o modelo brasileiro sucintamente para verificar de que modo esse percurso distinto de construção do padrão de

\footnotetext{
${ }^{21}$ Conferir, a esse respeito MARTINS, 1989; FAUSTO, 2000a; SIMÃO, 1966.

${ }^{22}$ Heloísa Martins cita um Boletim do Ministério do Trabalho de dezembro de 1934 extremamente ilustrativo: “[...] iniciou-se um período de vida industrial e começaram a aparecer, inevitavelmente, os conflitos entre o capital e o trabalho. O Governo não podia ficar indiferente a este estado de coisas, perturbador da ordem social. Devia e cabia-lhe intervir” (1989, p. 25).
} 
intervenção social e da própria cidadania ${ }^{23}$, profundamente determinado pelo autoritarismo das iniciativas que o conformaram, foi responsável por um produto igualmente distinto, denominado por alguns de uma cidadania regulada (SANTOS, 1979), e por outros de estadania (CARVALHO, 2004, p. 221) ${ }^{24}$.

As conseqüências mais agudas desse modelo foram o comprometimento das possibilidades de ação social coletiva, como resultado da alternância entre práticas de repressão, incorporação e anulação das entidades de representação do trabalho organizado e da institucionalização dos conflitos. O desenvolvimento desse modelo, ademais, ao criar clientelas privilegiadas e uma burocracia própria dotada de relativa autonomia decisória, bem como incorporar lideranças sindicais formando uma verdadeira oligarquia ${ }^{25}$, solidificou suas características institucionais e programáticas e criou barreiras significativas para o encaminhamento de alternativas ao esquema oficial de representação e expressão dos conflitos trabalhistas.

Nesse sentido, portanto, o modelo criou um sindicalismo burocratizado, leal e dependente do Estado que, acomodado e beneficiado por ele, tornou-se o maior opositor de sua transformação. O Estado tornou-se um distribuidor de recursos e benefícios, para os quais competem as entidades organizadas e suas lideranças. Além de impedir a construção de um novo modelo menos heterônimo e mais dinâmico de organização dos interesses dos trabalhadores, o modelo de regulação construiu novas clivagens sociais, separando as lideranças sindicais das bases trabalhadoras e cindindo o movimento operário em torno de categorias profissionais e localidades.

O alinhamento das clientelas formadas pelo padrão de regulação social no Brasil não representou, entretanto, a completa anulação da ação coletiva, até porque o operariado não encontrou, no Estado, espaços para vocalização de seus interesses mais legítimos. Assim sendo, dada a dinâmica dos conflitos sociais, seria irresponsável reduzir a ampliação dos direitos sociais e a proteção do trabalho a um interesse explícito das forças hegemônicas de controle social para o trabalho no interior de um projeto nacional de acumulação capitalista. Estar-se-ia desconsiderando o papel dos atores sociais como

\footnotetext{
${ }^{23}$ Distinção que ganha relevo quando a noção de cidadania desenvolvida no país e seu percurso evolutivo é cotejada com o desenvolvimento modelar descrito por T. H. Marshall (1992) para o caso inglês.

${ }^{24}$ Deve-se reconhecer que a idéia aqui exposta de que uma linha evolutiva e um modelo distintos de organização social e de cidadania afetam seus produtos foi já aventada por Murilo de Carvalho (2004, p. 221).

${ }^{25}$ A tese da oligarquia sindical e o processo de oligarquização pelo qual passam as lideranças sindicais será melhor analisado adiante. A expressão, porém, não é nova e pode ser encontrada em Santos (1979).
} 
agentes históricos e o fato atestado, anteriormente exposto, de que as mobilizações do operariado orientam-se para a aquisição desses mesmos direitos.

As teses sobre a passividade do operariado nacional há muito têm sido afastadas (OLIVEIRA, F. 2006, p. 145) e há razões para acreditar que sempre houve setores representativos não associados ao esquema oficial e, portanto, praticantes de uma ação autônoma. Em especial, como se analisará, foram nos momentos de agravamento das condições de vida da classe trabalhadora, motivados pela perda de seu poder de compra, quer por arrochos salariais, quer pela ascensão de preços dos gêneros de primeira necessidade, que eclodiram as formas mais autônomas, e também combativas, de mobilização operária (MARTINS, 1989; FAUSTO, 2000a, p. 164). Mesmo a concessão de direitos trabalhistas, a criação de programas sociais e da Justiça do Trabalho corresponderam, indubitavelmente, à consolidação, no nível institucional e jurídico, de algumas condições que já haviam sido de fato conquistadas pela luta dos trabalhadores desde o início do século XX, como não apenas a literatura sobre o tema (SIMÃO, 1966; FAUSTO, 2000a; DIAS, 1977) ${ }^{26}$, mas mesmo Oliveira Vianna, consultor jurídico do Ministério do Trabalho e formulador da legislação, reconheceu: “O nosso labor foi antes o de dar técnica legislativa e sistematização a esse direito costumeiro encontrado, a esse complexo de normas e costumes, que nos havia sido 'revelado' e que regulava - pelo único prestígio da tradição e do costume - a atividade dos nossos trabalhadores e as suas relações com o patronato” (1999, p. 46. Destaques no original).

O início dos debates e da consciência em torno da necessidade de conferir um tratamento não puramente repressivo à questão social, como reconhecem esses autores, deu-se justamente em virtude da intensa movimentação operária nos grandes centros urbanos no final da década de 1910. Contudo, era ainda tímida a participação dos trabalhadores assalariados na população nacional e mesmo as violentas greves de 1917 e 1918, que irromperam nas cidades de São Paulo e Rio de Janeiro, não foram suficientes para produzir uma resposta estatal articulada, senão a usual repressão ${ }^{27}$. O impacto de sua

${ }^{26}$ Everardo Dias, militante sindical e profundo conhecedor do sindicalismo na Primeira República assim se refere ao fato:

Quase tudo que está consubstanciado e inscrito no Código do Trabalho já havia sido conquistado através de lutas ásperas e de terríveis repressões policiais, de espancamentos e torturas dos líderes de então, de inúmeros conflitos em que o proletariado foi o mais sacrificado e vilipendiado. A lei veio dar valor legal a uma situação de fato, a uma situação que já existia [...] (DIAS, 1977, p. 217).

${ }^{27}$ Utilizando dados de Vilella e Suzigan, autores de um vasto estudo sobre a política estatal e o fomento à economia nacional na primeira metade do século XX, Fausto aponta que, em 1920, a população ocupada na indústria era de apenas 13,8\% do total, isto é, 1,264 milhão de pessoas (2000a, p. 20). Ainda assim, é 
mobilização, de igual modo, era limitado e, por quanto atacava o mundo urbano e industrial, ainda pouco representativo em termos econômicos e de fonte do poder político (FAUSTO, 2000a, p. 22).

O primeiro reconhecimento, pelo Brasil, da questão social, deu-se com o Tratado de Versalhes, em 1919, mas apenas com o movimento revolucionário de 1930 o Estado passa a nela intervir de modo articulado (MARTINS, 1989, p. 183). Assim sendo, a construção do modelo de intervenção social no país, principalmente em seu aspecto de organização do trabalho, partiu de uma iniciativa estatal e há fortes indícios de que esteve orientada para o reconhecimento das ocupações estratégicas para o projeto de desenvolvimento nacional e à racionalização da gestão dos conflitos sociais, de modo a não ameaçar esse mesmo projeto. Os interesses do trabalho foram seletivamente institucionalizados no seio do Estado, que com isso pôde regular intensivamente a ação coletiva do operariado, neutralizando-a e impedindo a manifestação autônoma do operariado, ao incorporar as formas representativas, tornando-as uma peça fundamental da conjugação de esforços para a consecução do projeto nacional desenvolvimentista.

Tampouco se pretende afirmar que a regulação jurídica do trabalho não representa ganhos para os trabalhadores. A proteção social beneficiou alguns setores contra o pauperismo na idade avançada e a normatização das relações de trabalho garantiu uma relativa melhoria das condições enfrentadas pelos trabalhadores na produção. Por outro lado, entretanto, o modelo corporativo de organização do trabalho no país, por meio dos processos de cooptação e burocratização das instâncias de representação e de gestão da política social, representou uma forma de repressão administrativa, na feliz expressão de Heloísa Martins (1989, p. 8), da ação coletiva dos trabalhadores.

O período de análise corresponde ao ciclo de formação, desenvolvimento e crise do modelo. Contribuem para essa crise e as iniciativas de reformas tanto o comprometimento de suas bases de sustentação, quanto um forte questionamento popular. Por um lado, o sistema fortemente apoiado na expansão das relações formais de trabalho e em programas sociais contributivos encontra atualmente limites para sua expansão diante do crescimento da economia informal e do desemprego estrutural. Por outro, a ausência de mecanismos de participação e controle da gestão, o caráter excludente do sistema de proteção social e o controle das entidades de representação dos trabalhadores e de suas ações pelo Estado

necessário reconhecer que, em meio à greve de 1917, o Estado viu-se compelido a dialogar e negociar com os trabalhadores, sendo que os jornalistas agiram como facilitadores da mediação entre Estado, patronato e lideranças das agremiações operárias revoltosas. 
conduziram, desde o final da década de 1970, a reivindicações de reformas ampliativas da participação democrática e maior autonomia na ação sindical. Não obstante, as características elementares do modelo de regulação do trabalho resistem ainda no país, por razões que se buscará analisar.

\subsection{Alguns antecedentes na formação do operariado e sua ação coletiva}

Embora seja evidente que os efeitos da concentração de esforços para o projeto nacional desenvolvimentista haveriam de se projetar, como não poderia deixar de ser, sobre a própria constituição da classe trabalhadora, não se pode inferir dessa colocação que tenha sido o Estado a força que organizou o operariado em classe. Os trabalhadores urbanos cresciam juntamente com a expansão da indústria e vinham se diferenciando como grupo desde o final do século XIX (SIMÃO, 1966, p. 13).

Em meio ao processo de formação da classe operária no período que se estende das últimas décadas do século XIX até o movimento revolucionário de 1930, dois determinantes estruturais com efeitos opostos destacam-se para explicar as possibilidades da constituição da classe e de sua ação coletiva. O primeiro deles corresponde às condições de oferta do mercado de trabalho e o segundo, à composição e às origens do operariado no período (FAUSTO, 2000a, p. 22).

Em condições tradicionais, a fase inicial do processo de industrialização, como a que o país atravessava, apresenta uma dinâmica de crescimento fortemente alicerçada na incorporação de maior volume de mão-de-obra, sendo secundário o papel desempenhado por inovações tecnológicas ou pelo capital fixo. A produção organizava-se ainda de modo artesanal e com poucas máquinas, até porque não havia mercados para os quais escoar uma produção mais significativa. Por outro lado, a oferta de trabalho era reduzida, pois, por um lado a maior parte da população estava incorporada ao setor primário, em atividades agrícolas estáveis e por outro, as condições de trabalho urbano não estimulavam a transferência da mão-de-obra. Nesse sentido, poder-se-ia esperar condições de escassez que valorizassem salários, conferissem maior estabilidade ao emprego um maior espaço para reivindicações e lutas. Ademais, também se poderia verificar uma ação organizadora do Estado no sentido de promover a oferta de trabalho no mercado (FAUSTO, 2000a). 
No Brasil, porém, a literatura aponta que os efeitos esperados na primeira fase de industrialização não se confirmaram, pois a população ocupada cresceu no período em ritmo muito inferior à ampliação da população na faixa de idade economicamente ativa (SIMÃO, 1966, p. 26; FAUSTO, 2000a, p. 23). O problema da força de trabalho na empresa agrícola cafeeira encontrara solução com a subsidiada e abundante imigração de mão-de-obra, incorporada na atividade rural. Como o fluxo migratório excedia as necessidades do setor, havia grande oferta de força de trabalho no período e até se formava um calculado excedente que servia para depreciar os salários rurais (FAUSTO, 2000a, p. 24).

Não coube aos braços excedentes alternativa senão transferir-se para os núcleos urbanos. Esse processo de transferência foi acentuado com a crise do setor cafeeiro e as dificuldades de acesso, pelos colonos, à propriedade da terra. Há indícios que essa população teria formado, então, um exército industrial de reserva antes mesmo da intensificação da industrialização. As crises econômicas do início do século também teriam contribuído para a formação desse exército com a redução do emprego industrial (FAUSTO, 2000a, p. 24; SIMÃO, 1966, p. 29). No Rio de Janeiro, ainda teria se somado, a esses fatores, a atração que a capital exercia para os migrantes internos e o afluxo de negros provenientes do campo fluminense para a cidade como resultado da abolição e da decadência do café, o que não ocorrera em São Paulo pela presença maciça dos imigrantes nas melhores ocupações (FAUSTO, 2000a, p. 25). Por assim dizer, ainda que sua composição fosse distinta, nos grandes centros urbanos São Paulo e Capital Federal havia um contingente de mão-de-obra à disposição para ser incorporado à produção tão logo fosse necessário.

Essa conjuntura de abundância da oferta de força de trabalho contribuiu para reduzir o alcance das lutas, dissuadir mobilizações e deprimir os salários. Ademais, não se mostrou necessária uma ação estatal de mobilização da força de trabalho, ou incentivo à proletarização ativa, nos termos de Offe e Lenhardt (1990). A política imigratória da República Velha foi suficiente para atender à necessidade colocada pela incipiente industrialização.

Outro fator determinante da formação do operariado como classe era a sua composição, com a maioria das ocupações industriais e de serviços sendo ocupadas por estrangeiros. Ao contrário das condições de oferta da força de trabalho, a composição majoritária de imigrantes na classe trabalhadora assalariada teve efeitos positivos e 
fomentou a organização da classe operária. A imigração teve expressivo papel na importação de ideologias que alimentavam a crítica e a negação do sistema capitalista. Ademais, a contradição entre as aspirações dos imigrantes e as condições de trabalho oferecidas constituiu um combustível para sua revolta (FAUSTO, 2000a, p. 29). Por certo que, para o desenvolvimento dessa atitude e a solidariedade que imigrantes e nacionais formaram em torno da causa operária, a identidade de classe deveria ser mais forte do que a nacional como, de fato, o era (idem, p. 33).

Se não há como negar que as forças socioeconômicas já permitiam a formação dos trabalhadores em classe, o mesmo não pode ser afirmado a respeito da existência de qualquer intervenção social ou organização significativa dos trabalhadores até o final da segunda década do século XX. Não havia qualquer forma de proteção efetiva do trabalhador contra os riscos do processo produtivo ou regulação das condições de trabalho que atenuassem a extração do excedente da produção (FAUSTO, 2000a, p. 105). Vigia um absoluto laissez-faire nas relações de trabalho, assim como nas demais áreas da política (SANTOS, 1979, p. 64).

Assim como não havia, tampouco, uma expressiva organização operária perene e representativa. Ao contrário, reinava um débil padrão de organização. A ação coletiva surgia esporadicamente, e por isso de modo descontínuo, a partir de pequenos núcleos que não representavam categorias e não vocalizavam interesses de grandes parcelas da população trabalhadora, sendo, ao cabo, sufocadas. A incapacidade de gerar benefícios significativos está, aliás, diretamente associada à posição que o Estado assumia perante a questão social, tratando-a, predominantemente, com a pura repressão do que julgava serem focos isolados de subversão (FAUSTO, 2000a; SIMÃO, 1966; SANTOS, 1979).

Outras dificuldades enfrentadas para a articulação de uma ação coletiva dos trabalhadores, além da resposta estatal repressiva, e até banidora dos elementos julgados instigadores, os estrangeiros, são também apontadas pela literatura (FAUSTO, 2000a, 121; SIMÃO, 1966). A primeira era a insipiência e descontinuidade da atividade industrial, que sem a proteção ou fomento estatal, sujeitava-se às crises internacionais e às variações no reduzido mercado interno. Esse quadro impedia, pela interrupção constante, o processo de formação da coesão e dos laços de solidariedade que caracterizam a classe. A segunda, a situação de carestia na década de 1910, como efeito das políticas econômicas recessivas e de crises econômicas, que reduz salários e aumenta a competição pelo emprego, tornando inúteis os esforços organizatórios (FAUSTO, 2000a, p. 157-8). 
A despeito da disponibilidade crescente de mão-de-obra na alvorada do século passado, e até mesmo a formação de um exército de reserva industrial, a falta de estabilidade nos surtos de industrialização e a fragilidade das organizações operárias comprometiam a composição de interesses dos trabalhadores e seu reconhecimento como ator coletivo.

Há um momento específico, na histórica brasileira, reconhecido por autores como Boris Fausto (2000a), Azis Simão (1966) e Heloísa Martins (1989) pela “emergência de um movimento social de base operária, nos centros urbanos do país”, responsável pelo maior número de greves da história brasileira, até o fim da Segunda Guerra Mundial, a realização de grandes manifestações, o avanço da sindicalização e o surgimento de uma imprensa operária de maior amplitude (FAUSTO, 2000a, p. 159). Trata-se do período compreendido entre a eclosão da greve geral de São Paulo, em 1917, os primeiros anos da década de 1920.

O movimento paulista de julho de 1917 foi o produto de um conjunto de fatores que, ademais, permitiram a superação de todos os obstáculos à emergência de uma ação coletiva mais duradoura e representativa. O principal deles foi o agravamento das condições da classe operária no curso da Primeira Grande Guerra, resultado da elevação dos preços de gêneros de primeira necessidade em virtude da emissão monetária inflacionária - para financiar a compra de excedentes agrícolas pelo Estado - e da elevação de custo de bens importados em meio à guerra, bem como da depressão salarial que se prolongava desde o início da década de 1910 (FAUSTO, 2000a, p. 164-5). Além disso, há indícios de que a agitação revolucionária européia inflamou o movimento por meio de sua divulgação na imprensa operária (idem, p. 171).

As reivindicações operárias, como evidencia a pauta que é apresentada pelo Comitê de Defesa Proletária, formado pela união das lideranças sindicais e de associações populares, concentravam-se na regulação das condições de trabalho, em especial das mulheres e crianças, na imposição de limites à exploração do trabalho, que evitassem a exaustão, e na intervenção do Poder Público para punir práticas comerciais desleais (FAUSTO, 2000a, p. 198). Por assim dizer, a despeito da força de elementos socialistas e anarquistas no movimento, a orientação primordial do movimento grevista era pela inclusão no sistema por meio da concessão de direitos e da regulação das relações de trabalho. 
Nesse sentido, trata-se de um momento em que o surgimento de uma ação coletiva autônoma ${ }^{28}$, combativa e sustentada das classes populares promoveu a emergência da questão social nos debates na sociedade e no parlamento, como reconhece Fausto (2000a, p. 159). A partir das sublevações dos trabalhadores e de seu surgimento como ator coletivo, não se podia mais ignorar a questão e os discursos eleitorais passaram a contemplar propostas tímidas de reforma social. O Estado via-se compelido a agir para conferir uma resposta a forças sociais emergentes que haviam se organizado.

Diante do surgimento da questão social, dois caminhos apresentaram-se para o Estado: tratá-la como uma subversão e adotar medidas repressivas ${ }^{29}$ ou legitimar os trabalhadores, integrando-os ao sistema vigente e concedendo direitos. Por óbvio, as oligarquias rurais no poder não tinham interesses ou propostas de administração da questão pela segunda forma. A predominância do ideário liberal nas elites promovia a contumaz negligência da questão, bem como a sistemática recusa, coerente com o laissez-faire, de intervir de qualquer modo distinto da pura e simples repressão (SANTOS, 1979, p. 65). Desse modo, as respostas repressivas foram predominantes. As iniciativas legislativas no período foram, via de regra, rechaçadas quando chegavam a ser analisadas e deliberadas, pela oposição dos liberais, que julgavam as iniciativas uma afronta à liberdade contratual e, como recorda Heloísa Martins, pela “política dos governadores”, isto é, pela excessiva autonomia estadual que negava à União, a competência legislativa sobre temas como a regulação das condições de trabalho (1989, p. 19) ${ }^{30}$. Além da criminalização da interrupção do trabalho e do aliciamento de operários para esse fim (arts. 205 e 206 do Código Penal

\footnotetext{
${ }^{28}$ Por ação coletiva autônoma compreende-se aquela desenvolvida em vista dos objetivos e segundo normas estabelecidas pelos próprios membros. Essas são justamente as características que Heloísa Martins reconhece nas associações operárias das primeiras décadas do século XX (1989, p. 16).

${ }^{29}$ A repressão, aliás, sempre representou uma alternativa à disposição do Estado para administrar excedentes e a escassez de mão-de-obra e continuou a sê-lo mesmo após a regulação legal das relações de trabalho e de suas organizações representativas. Um belo estudo a respeito da gestão penal do mercado de trabalho e da orientação da mão-de-obra para a acumulação capitalista pode ser encontrado em Rüsche e Kirchheimer (1984).

${ }^{30}$ Aziz Simão (1966) e Boris Fausto (2000a) apontam quais as propostas e documentos legislativos mais importantes do período, ressaltando que sempre que aprovados, foram de aplicação restrita: o Decreto Legislativo 1.637, de 5 de janeiro de 1907, depois transformado em lei, facultou a livre criação de sindicatos, federações e sociedades cooperativas, independentemente da autorização do governo. O reconhecimento da entidade como representante da categoria só era conferido, entretanto, às associações reconhecidas como portadoras de um espírito de cooperação entre patrões e operários (FAUSTO, 2000a, p. 224); o Decreto 2.141 de 1911 (convertido na lei 1.596/1917) disciplinava as condições de higiene nas fábricas, proibia atividades de menores de 10 anos e o serviço noturno para os menores de 18; a lei 1.904/1915, de indenização por acidentes de trabalho, que não teve resultados práticos; e, por fim, o Código do Trabalho (Decreto 3.550, de 16 de outubro de 1918), produto de vários substitutivos, apresentados após o resgate de uma antiga proposta diante das agitações de 1917 e 1918, que sucessivamente limitaram o alcance e mutilaram o projeto original. Em virtude da omissão com relação à fiscalização das condições que estabelecia, o documento jamais foi cumprido.
} 
de 1890), foram reforçadas as leis de expulsão de estrangeiros, removendo-se antigas restrições em virtude do estabelecimento de família ou o período de residência no país (FAUSTO, 2000a, p. 234, 235). Todavia, a resposta repressiva mostrou-se ineficaz para interromper a escalada da violência ou mesmo dissuadir os grevistas. Alimentou, ao contrário, a ira das classes populares, que investiram até mesmo contra as autoridades (idem, p. 196). Nesse contexto, os movimentos ganham fôlego, as agremiações prosperam e saem da clandestinidade ${ }^{31}$.

A incapacidade de propor soluções em meio ao incremento do conflito industrial e urbano, como ademais o fracasso das políticas econômicas geradoras de um crescimento econômico reduzido, interrompido por quadros recessivos e a inaptidão para promover uma forma alternativa de acumulação, consistente no desenvolvimento da indústria nacional de modo sustentado, protegendo-a das oscilações internacionais, promoveram o isolamento político das elites agro-exportadoras de São Paulo e Minas Gerais e conduziram ao movimento revolucionário de 1930 (SANTOS, 1979, p. 67).

\subsection{0-1945: A fundação do aparato corporativo no Brasil na Era Vargas}

\subsubsection{Fundação e elementos de formação do modelo corporativo}

A intervenção estatal na questão social no Brasil insere-se em um conjunto de questões que ganham urgência em face de sensíveis modificações da estrutura social resultantes da aceleração da industrialização e urbanização no país (DRAIBE, 1994, p. 277). Há, portanto, uma nítida associação entre o processo de industrialização pelo que atravessa o país e a constituição de uma resposta estatal à questão social, especialmente na forma de organização e regulação do trabalho.

Por óbvio, a população operária cresceu no país à medida que surgiam novos estabelecimentos industriais e com ela os conflitos que pressionavam por uma intervenção estatal na questão social. Durante as primeiras décadas do século XX, porém, era comum haver crises de superprodução no restrito mercado interno nacional e, desse modo, assim

\footnotetext{
${ }^{31} \mathrm{O}$ relato do sindicalista Everardo Dias é rico na descrição do período. Além de descrever as respostas repressivas pontuais às greves de 1917 e 1918, o militante destaca que, mesmo com a resposta estatal, prolifera-se uma rica imprensa que divulga manifestos, exalta as vitórias operárias e promove a agitação (DIAS, 1977).
} 
como a indústria, a população ocupada era inconstante (SIMÃO, 1966; FAUSTO, 2000a). O período compreendido pela Era Vargas e pela segunda metade da década de 1940, foi um momento de crescimento sustentado da indústria, em que a população nela ocupada cresceu em igual proporção que o número de estabelecimentos industriais, como revelam os dados de Aziz Simão (Tabela 1). Essa aceleração da industrialização, em condições relativamente estáveis, só pode ter como fenômeno contribuinte a ação estabilizadora do Estado, aspecto da nova posição do Estado na direção e promoção das atividades econômicas.

Tabela 1: Industrialização e crescimento da força de trabalho industrial na Era Vargas

\begin{tabular}{|c|c|c|c|c|c|c|c|c|c|}
\hline \multicolumn{9}{|c|}{ Brasil } & \multicolumn{5}{c|}{ Estado de São Paulo } \\
\hline $\mathrm{T}$ & Estab. & Base & Operários & Base & $\mathrm{T}$ & Estab. & Base & Operários & Base \\
\hline 1920 & 13.336 & 100 & 176.548 & 100 & 1920 & 4.145 & 100 & 83.998 & 100 \\
\hline 1950 & 89.086 & 667 & 1.256 .807 & 711 & 1950 & 24.519 & 591 & 484.844 & 577 \\
\hline
\end{tabular}

Fonte: elaboração a partir de SIMÃO, 1966, p. 43-5.

Além de ser impulsionada pelo desenvolvimento das forças produtivas fabris, portanto, a gênese do operariado enquanto classe no Brasil será igualmente alimentada pela ação diretora do Estado, em seu projeto industrializador. Do mesmo modo, a organização do trabalho no país foi determinada tanto pela necessidade de responder aos conflitos inflamados pela situação de carestia que afetava o operariado, quanto pela necessidade de organizar a força de trabalho de forma eficiente para o projeto nacional-desenvolvimentista empreendido pelo movimento revolucionário de 1930, criando formas de intermediação dos conflitos que não interrompessem a produção ou ameaçassem a ordem. Reconhecendo o expressivo impacto da industrialização e da projeção da sociedade urbana na vida nacional para a constituição do operariado como classe, a urgência de suas questões e a organização do trabalho no país, o estudo de Aziz Simão (1966, p. 3) aponta que a mudança da posição governamental no plano econômico teve precedência sobre a própria dinâmica socioeconômica para a formação de vínculos entre sindicatos e o poder público que constituíram um novo padrão de relações entre o operariado, o capital e o Estado.

É certo que a marcha industrializadora conferia os limites em que se processariam as relações sociais entre as classes. Conforme apontado, ela impulsionava a formação do operariado e da questão social nos grandes centros urbanos nas primeiras décadas do século XX. Porém, apenas com uma nova atitude do Estado em face dos fatores 
econômicos, que incluiu a interferência nas relações entre as classes, o trabalho, suas condições e conflitos seriam organizados pelo Estado. Essa atitude se inscrevia, justamente, no projeto de desenvolvimento posto em marcha pela revolução de 1930, que incluía a superação das deficiências que impediam o progresso das forças produtivas industriais no país e a organização do crescimento (SIMÃO, 1966, p. 40). Desse modo, a ação estatal era, ademais, promotora das transformações socioeconômicas que determinavam as novas relações.

Resta saber, então, como se constituiu o modelo de resposta estatal de intervenção social, regulador das relações de trabalho, quais seus elementos de formação e quais seus atributos e orientações.

As propostas de encaminhamento da questão social, como também as alternativas em termos de projeto de acumulação para o país provieram de alguns membros da elite industrial e de membros da sociedade detentores de uma ideologia positivista, dispostos a conceder direitos e organizar o trabalho para garantir a ordem e a continuidade do processo produtivo, que se associaram na formação de um modelo de intervenção social informado por essa mesma ideologia.

Informado pela obra sociológica de Auguste Comte, o positivismo difundiu-se originalmente em um núcleo da sociedade que almejava apenas a concessão de direitos sociais, salário justo, instrução pública universal e reconhecimento do papel do proletariado na ordem social ${ }^{32}$. Não pretendia, entretanto, a organização da classe trabalhadora. A proposta positivista partia da doutrina de Comte, segundo a qual a decomposição da organização social antiga em meio a transformações científicas exigia um esforço de reorganização pela difusão de elementos morais, empreendida pela potência espiritual, que garantissem a coesão social. Julgava ser necessário regenerar a sociedade pelo impulso científico e a evolução intelectual e via, no operariado, essa potência capaz de levar a cabo o intuito. No início da República os positivistas defenderam a incorporação do

\footnotetext{
32 Embora tradicionalmente associado a integrantes do movimento de 1930 de origem gaúcha, como Lindolfo Collor, o positivismo tomou no Brasil formas heterogêneas em distintos grupos e não pode ser reduzido às posturas dos integrantes da classe política do sul do país. Durante a República Velha, aliás, os representantes políticos sulistas, sob a sombra de seus longevos líderes Borges de Medeiros e Júlio de Castilhos, constituíram uma das principais forças de oposição à legislação social, juntamente com os liberais paulistas, estes por entenderem-na contrária a seu ideário liberal e aqueles por considerarem-na uma invasão da União nos assuntos do Estado (FAUSTO, 2000a). Os positivistas pertencentes ao grupo de Castilhos e Medeiros revelavam uma leitura muito própria da obra de Comte e expressavam sua divergência em relação aos positivistas mais ortodoxos do Rio de Janeiro. Essa variação do positivismo foi denominada por Alonso (2000, p. 52) de “federalismo científico”.
} 
proletariado e o reconhecimento de direitos sociais, julgando a questão de suma importância, pelo seu papel para o impulso que conduziria à modernização e industrialização do país (FAUSTO, 2000a, p. 48-9).

No Brasil, difundiu-se, sobretudo, nas escolas militares, em círculos intelectuais urbanos e em meio a grupos marginalizados pela monarquia (ALONSO, 2000, p. 43), e foi um importante elemento do movimento republicano, alijado do poder pela oligarquia cafeeira. Sua força nesses segmentos devia-se ao fato da ideologia constituir uma alternativa ao bacharelismo e à retórica vazia reinante nos círculos acadêmicos e políticos nacionais, na qual se identificavam os sinais da degeneração social a exigir uma reforma.

Na luta contra a oligarquia rural, patrocinada pela elite industrial alijada do poder (MARTINS, 1989, p. 14), as figuras positivistas da velha república são resgatadas e seus elementos militares exaltados (FAUSTO, 2000a, p. 60). Dentre os setores promotores da Revolução de 1930, há um grupo de intelectuais getulistas ligados a Lindolfo Collor claramente influenciado pela doutrina positivista (RODRIGUES, 1990, p. 50) que, no momento, encontrava-se já reelaborada, à luz de questões e interesses próprios dos grupos propagadores no país ${ }^{33}$. Ganha relevo, nesse contexto, a necessidade de organização do trabalho e de um projeto estatal de fomento à indústria. A organização era compreendida como geradora da ordem sem a qual, nos termos de Comte, não havia condições para o progresso que a indústria representava.

Na construção do modelo corporativo, o positivismo interferiu no projeto, portanto, de modo adaptado e até mitigado, por meio da proposta formulada por esse grupo de intelectuais, dentre os quais se notabilizaram Evaristo de Moraes Filho e Oliveira Vianna, que se tornaram assessores jurídicos de Collor no recém-criado Ministério do Trabalho, Indústria e Comércio. Além de orientações corporatizantes, o grupo defendia uma administração técnica e racional e menos política, ao gosto do ideário cientifizante do positivismo. A proposta do grupo para a intervenção social seria encabeçada por Vianna, cujo diagnóstico da situação social no país foi apropriado pelos revolucionários de 1930 e confundia-se com a justificativa que o governo apresentou para o encaminhamento da organização do trabalho e da representação política a partir de um modelo corporativo. O intelectual apontava que o país padecia de uma absoluta deficiência associativa, intrínseca

\footnotetext{
${ }^{33}$ Ressalte-se que o positivismo é difundido mais amplamente a partir de políticos ou obras políticas cujo discurso abraçava a retórica positivista, como argumento de autoridade, e não a partir das obras "filosóficas" dos positivistas. Desse modo, a referência era raramente direta aos textos dos pensadores positivistas e a ideologia podia ser moldada aos interesses de seus defensores (ALONSO, 2000).
} 
a uma nação agrária, e da ausência do espírito de solidariedade ${ }^{34}$. Mesmo as classes e seus conflitos, acreditava, não se constituíam ainda no país, tomado por um individualismo e pelo atomismo dos movimentos supra-individuais. Por essa razão, julgava necessário promover o "espírito de clã” e neutralizar a ação nociva que impedia seu florescimento (VIANNA, F. J. O., 1999, p. 466) ${ }^{35}$. Em outros termos, era necessário, a seu ver, organizar as classes e promover a unidade nacional, antecipando até os conflitos que poderiam minála. Essa visão não reconhecia, obviamente, o papel associativo das classes populares e o seu crescente papel nas primeiras décadas do século.

A proposta resultante desse diagnóstico, de matriz corporativa, possuía um forte caráter autoritário e veio acompanhada de um espírito nacionalista, produto de sua aversão à importação de soluções estrangeiras. De acordo com Vianna, a ação estatal no campo social deve fazer uso de uma das duas técnicas a seu dispor: a liberal, em que se valoriza o papel organizativo e transformador da sociedade, ou a autoritária, em que o Estado substitui à sociedade esse mesmo papel. Diante de seu diagnóstico, apenas a segunda apresentava potencial de sucesso no Brasil:

\begin{abstract}
O grande erro ou a grande ilusão de nossos reformadores é querer que o povo mude - por ação de uma política de Estado - o seu comportamento tradicional da vida pública, dentro de regimes liberais. Quando a mudança que a nova lei exprime, ainda não se manifestou nos costumes, mas significa uma atitude nova a ser tomada sob a ação de ditames legais ou Cartas Constitucionais, o meio de se conseguir do povo esta mudança seria fazê-la acompanhada de sanções penais; quer dizer: seria torná-la efetiva pela coação (VIANNA, F. J. O., 1999, p. 448. Destaque no original $)^{36}$.
\end{abstract}

\footnotetext{
${ }^{34}$ A percepção de Vianna, segundo a qual no país não havia mais do que uma pluralidade de comunidades familiares, ausentes os espíritos de unidade e solidariedade nacionais, é manifestada de modo reiterado na totalidade de sua obra, mas é bem ilustrada no seguinte fragmento de Instituições Políticas Brasileiras:

[...] hábitos de solidariedade, que são de povos estranhos, de povos de outra formação social que não a nossa; povos em cujas tradições o associacionismo, o cooperativismo, a solidariedade local, como vimos, é dominante e está nos costumes; - e isto por mil e uma causas que não tiveram atuação entre nós. [...] Nossa formação se processou segundo um desenvolvimento que se caracteriza por um nítido, rude, vigoroso individualismo em antagonismo patente com qualquer tradição de solidariedade social e menos ainda de espírito comunitário (1999, p. 443-4).

${ }^{35}$ A despeito de suas posições, deve-se prestar a devida deferência à interpretação de Oliveira Vianna. Certamente Vianna não é o único responsável intelectual pelo aparato jurídico varguista, que recebeu aportes de muitos outros atores interessados. Ademais, sua obra tem o inegável mérito de contrapor sistematicamente o país real ao legal e privilegiar a constituição real. Trata-se de uma qualidade rara em meio ao pensamento formalista que predominava no pensamento social brasileiro até o início do século XX, quando a intelectualidade era quase toda egressa dos cursos jurídicos.

${ }^{36}$ Não obstante, como já apontado,Vianna reconhecia no prefácio de sua obra Instituições Políticas do Brasil (1999, p. 46) que muito da legislação trabalhista que ele e os outros "técnicos do Ministério" do Trabalho haviam criado era simples sistematização de práticas costumeiras.
} 
Vianna pretendia a formação de um modelo corporativo de organização de classes profissionais e econômicas em uma estrutura sindical vertical e simétrica. Isso garantiria a empregados e empregadores a equivalência no número de associações de representação perante o Estado, de modo a equilibrar o poder. Ademais, pretendia a criação de um órgão jurisdicional especializado na mediação dos conflitos individuais e coletivos do trabalho uma Justiça do Trabalho - e o estabelecimento do monopólio da representação sindical, considerado indispensável para organizar as relações de classe, além da contribuição compulsória para o sindicato da categoria, garantindo seu funcionamento (COSTA, V. M. R., 1991).

Contudo, o positivismo não seria a única ideologia a informar a proposta de acumulação e intervenção social que surgiu no país, e nem a proposta de Vianna foi adotada em sua integridade. A resposta estatal foi o resultado de um amálgama de ideologias e propostas. Confluíram, como assinala Ribeiro Costa (1991), a formulação da elite industrial paulista, a de Oliveira Vianna e a de integrantes do governo provisório, podendo-se identificar nessas últimas influências positivistas ${ }^{37}$. Além deles, o tenentismo também defendia um modelo de representação política classista, isto é, apoiado na divisão de profissões, embora se opusesse ao Ministério do Trabalho (RODRIGUES, 1990, p. 51).

A iniciativa de montagem do sistema de intervenção social não partiu da elite industrial paulista (idem, p. 63), mas dele recebeu aportes e suas reivindicações foram responsáveis pela mitigação da proposta de Vianna. O patronato oscilava, em suas propostas, entre um modelo autônomo e um corporativista, mas penderia no decorrer da Era Vargas para o segundo (FAUSTO, 2000a; COSTA, V. M. R., 1991). Compreender sua posição em meio à construção do modelo de intervenção social no país é fundamental para verificar a hipótese de que a organização do padrão de intervenção social no país foi instrumental ao projeto nacional-desenvolvimentista de acumulação iniciado pela revolução de 1930 e, desse modo, foi orientado para a conjugação de forças.

Se a organização do trabalho, assim como a disciplina legislativa das condições de compra e venda da força de trabalho e da organização sindical inseriam-se em um projeto

\footnotetext{
${ }^{37}$ Vanda Maria Ribeiro Costa (1991) analisa cada um dos elementos e propostas que confluíram para o modelo corporativo desenvolvido no país, demonstrando claramente as diferenças entre um projeto mais vinculado ao liberalismo, propugnado pela elite industrial paulista, o projeto de Oliveira Vianna e a formulação estatal efetiva. Ganha relevo a separação que estabelece entre a proposta de Vianna e o sistema instituído pelo Ministério do Trabalho, destacando os instrumentos jurídicos e institucionais imaginados pelo sociólogo que não seriam utilizados ou teriam seus efeitos potenciais anulados. Costa defende, ainda, que esse distanciamento do projeto original e das idéias de Vianna deveu-se à adaptação desse a interesses próprios do Estado, em comunhão com a elite industrial.
} 
de manutenção da ordem e mobilização das forças produtivas para o projeto de desenvolvimento, tais iniciativas deveriam encontrar o apoio do empresariado, por ser de seu interesse a promoção da acumulação. Ocorre, porém, que o empresariado, em especial o paulista, opôs-se vigorosamente à instalação do Ministério do Trabalho e à implementação de legislação trabalhista (COSTA, V. M. R., 1991, p. 114).

Foram dois os alvos da oposição, assim como as formas de sua manifestação. A oposição empresarial dirigia-se tanto ao modelo escolhido pelo governo e a sua estrutura, quanto à concessão de direitos trabalhistas e à intervenção social em si. Ambas manifestaram-se tanto na forma de debates públicos, encaminhamento de propostas legislativas e reivindicações dirigidas ao Executivo, quanto por meio do descumprimento sistemático de leis (COSTA, V. M. R., 1991; SIMÃO, 1966). Mas a oposição empresarial era, de um modo geral, antes dirigida contra o modelo escolhido pelo governo e sua estrutura, do que contra a idéia de regular e proteger o trabalho. O conflito industrial era visto pelo patronato sob a ótica de seus custos econômicos: representava uma ruptura de processos produtivos e, nesse sentido, devia ser evitada (SIMÃO, 1966, p. 122). A superação das dificuldades de administrar os conflitos e unir os setores sociais em torno de um projeto nacional era, aliás, uma demanda esposada pela mesma burguesia paulista há muito.

Desse modo, não há indicativos contundentes de que tenha havido uma oposição unânime e sistemática do empresariado à intervenção social. Estudos de Fausto (2000a) e Simão (1966) apontam que não se podia extrair, do interior da classe industrial, posições uniformes. Se a desorganização dos interesses do trabalho e a debilidade, instabilidade e falta de representatividade são as características de suas agremiações, o quadro no setor industrial apresentava uma única distinção, que era permanecer a salvo das investidas policiais. Não havia entidades que pudessem comunicar intenções e propostas unívocas do empresariado. Cada industrial, ademais, relacionava-se com sua própria força de trabalho e negociava as condições de trabalho que entendia cabíveis.

A greve de julho de 1917 é um caso em que se evidencia a falta de unidade de posições e propostas entre os empresários com relação ao conflito industrial e as formas de gerenciamento das relações de trabalho. Parte da elite mostra-se disposta a atender às demandas salariais e o faz prontamente, enquanto outro segmento permanece inflexível às reivindicações. Havia, no interior da classe, até mesmo um grupo, minoritário, sempre representado na literatura pela figura de Jorge Street, que era favorável também a uma 
legislação social que estabelecesse direitos e deveres para as associações operárias e patronais e criasse tribunais de arbitragem (FAUSTO, 2000a, p. 223). Jorge Street seria, aliás, um fiel colaborador de Lindolfo Collor na montagem do Ministério do Trabalho (DHBB, 2008).

O apoio empresário à regulação do trabalho também é expresso na postura e comportamento legislativo de um político paulista egresso da burguesia. Eloy Chaves, Secretário de Justiça e Ordem Pública quando da eclosão da greve, dedica esforços a persuadir os industriais a conceder as demandas operárias em nome do resgate da ordem. Mais tarde, seria o autor da primeira iniciativa legislativa de proteção social.

Não há como negar, porém, que havia um segmento contrário a qualquer iniciativa de intervenção social e organização do trabalho, mas esse era bem mais tímido do que aquele que se opunha ao modelo escolhido pelo governo. No geral, essa oposição generalizada à intervenção social apontava para uma estreiteza de visão, pela primazia da promoção de interesses imediatos, como a manutenção do trabalho extraído, em detrimento do interesse mais perene e global da classe, correspondente à promoção do desenvolvimento das forças produtivas e à manutenção da ordem com o arrefecimento dos conflitos.

No que tange à oposição contra o modelo estruturado pelo Ministério do Trabalho, essa parece haver se concentrado no primeiro momento da Era Vargas, perdendo força no decorrer da década de 1930, com as sucessivas concessões aos interesses do empresariado. O momento de maior expressão pública do conflito entre a proposta do Ministério do Trabalho e o empresariado parece ter sido quando da apresentação em 1936 do projeto de reorganização da Justiça do Trabalho e regulamentação dos dispositivos que dela tratavam na Constituição de 1934. O projeto, elaborado por Oliveira Vianna, foi duramente atacado pelo deputado e jurista Waldemar Ferreira, patrocinado pelos interesses empresariais paulistas. O Decreto-Lei 1.402, de 5 de julho de 1939, que regulamentava a associação sindical à luz da nova Constituição, igualmente encontrou oposição no empresariado. Nesse caso, porém, não porque se compreendia exacerbada a concessão aos trabalhadores, mas sim porque o documento definia, a partir da organização da estrutura de representação de empregados e empregadores, a participação de cada um no interior do Estado e, assim, nos rumos políticos (COSTA, V. M. R., 1991, p. 115). A elite buscava, portanto, maior espaço para a vocalização de seus interesses, a articulação de suas demandas e influência na tomada de decisões políticas (idem, p. 118). Ademais, embora a proposta da burguesia 
liberal paulista não fosse vitoriosa na formação do modelo brasileiro, a construção do mesmo contou com a participação desse estrato social.

Os conflitos em torno da idéia e do desenho que deveria tomar a intervenção social organizadora do trabalho no país, assim como o sistemático descumprimento da legislação trabalhista pelos empresários, encerraram-se, de acordo com indícios, com a aprovação da Consolidação de Leis do Trabalho (CLT), em 1943, instrumento jurídico que completou a montagem do edifício corporativo no mundo do trabalho, incorporando as demandas da elite por mais espaços políticos. O governo revolucionário negociou com a elite empresarial e fez concessões. Essa negociação seria coordenada, aliás, por Marcondes Filho, figura próxima ao presidente da Federação das Indústrias do Estado de São Paulo (FIESP) Roberto Simonsen, que gozava de amplo apoio entre industriais ${ }^{38}$. A nomeação do advogado Marcondes Filho para o Ministério do Trabalho confirma a participação desse estrato social na formação do edifício corporativista de regulação das relações de trabalho (COSTA, V. M. R., 1991, p. 116).

Ao construir um aparato de regulação do trabalho em moldes corporativistas, não apenas o governo Vargas atendeu aos interesses mais globais da classe industrial, como também concedeu uma série de benefícios, promovendo alterações ao projeto de Oliveira Vianna: criou uma estrutura corporativa assimétrica, conferindo espaços exclusivos de participação do empresariado junto à máquina, empregou a legislação também para reprimir qualquer ação operária que pusesse em risco a continuidade da produção e consagrou algumas das propostas dos industriais na Constituição de 1934. No momento em

\footnotetext{
38 O advogado Alexandre Marcondes Machado Filho nasceu em São Paulo, em 1892. Formado pela Faculdade de Direito de São Paulo em 1914, integrou o Partido Republicano Paulista (PRP), pelo qual se elegeu vereador da capital paulista em 1926 e deputado federal no ano seguinte. Foi partidário da candidatura presidencial de Júlio Prestes nas eleições de 1930 e apoiou o Movimento Constitucionalista deflagrado em São Paulo em 1932. Com a derrota do movimento e a consolidação no poder de Vargas afastou-se do poder até 1937 quando, após a instalação do Estado Novo, foi nomeado vice-presidente do órgão de intervenção federal no estado de São Paulo, o Departamento Administrativo do Estado de São Paulo (DAESP). Notabilizou-se, entretanto, por sua atuação como Ministro do Trabalho de Vargas, cargo que ocuparia ao substituir o criador da pasta, Lindolfo Collor, em dezembro de 1941. Durante sua gestão suas principais obras foram intensificar o controle estatal sobre as organizações sindicais e a sistematização e o aprimoramento de toda a legislação social até então produzida, na Consolidação das Leis do Trabalho (CLT), que decretou em maio de 1943. Desde 1942, Marcondes Filho acumulou o cargo com a pasta da Justiça. Já em 1945, por solicitação de Vargas, elaborou um projeto abertura política do regime que se tornaria a base da Lei Constitucional que convocaria eleições no mesmo ano. Manteve-se no governo até a deposição de Vargas, em outubro de 1945. Após o término do primeiro período de governo Vargas, dedicou-se à organização do Partido Trabalhista Brasileiro (PTB), como forma de canalizar o prestígio de Vargas e dos próprios dirigentes do ministério para a disputa eleitoral. Ocupou ainda os cargos de senador por São Paulo e assumiu a presidência da casa legislativa em 1954. Foi novamente Ministro da Justiça de Café Filho, durante curto período em 1955, após o qual se retirou da vida pública. Faleceu em São Paulo em 1974 (Dicionário Histórico-Biográfico Brasileiro, 2008).
} 
que esse foi substituído pelas formas mais rígidas e controladoras de organização estabelecidas a partir do Estado Novo, pela Constituição de 1937 e pela Consolidação das Leis do Trabalho, em 1943, a oposição, como apontado, era já reduzida, porque a política de intervenção surtira já seus efeitos de arrefecimento do conflito e assumira conformações que interessavam aos empresários. Oliveira Vianna reconhece que, aos poucos, os empresários parecem convencer-se das vantagens do modelo corporativo aprovado: “Quanto à legislação social: é visível que o patronato a vai aceitando sem muita relutância - e cada vez mais boamente” (1999, p. 467).

Como resultado dessa confluência de interesses e ideologias, conformou-se uma proposta autoritária de reforma social, que julgava ser necessário forjar uma unidade nacional entre as classes $^{39}$, o que seria promovido por meio de uma organização corporativa da sociedade, fundada em uma estrutura hierárquica de representação profissional. A mudança de comportamento do Estado com relação aos sindicatos deve-se, justamente, à sua integração e adaptação funcional a essa estrutura, como forma de eliminação dos motivos de conflito e tensão (MARTINS, 1989, p. 3).

Segadas Vianna, Ministro do Trabalho no segundo governo Vargas, reproduziria a mesma concepção de Oliveira Vianna, sociólogo, ao compreender o sindicalismo como “o corretivo mais eficiente desse excessivo espírito individualista, ao mesmo tempo que [sic] o instrumento mais poderoso que podemos utilizar para levarmos as nossas classes profissionais à consciência dos seus interesses comuns” (VIANNA, S., 1953, p. 37).

Os interesses comuns, por sua vez, eram expressos por idéias como a unidade nacional e a cooperação entre as classes, faculdades cuja ausência na população brasileira Oliveira Vianna vinha denunciando. Na legislação sindical, a unidade nacional seria associada à unicidade sindical, sobre a qual os burocratas do Ministério do Trabalho discorriam longamente em discursos, propostas legislativas e documentos. E para isso, valiam-se de modo contumaz das lições do sociólogo ${ }^{40}$. A pluralidade era considerada, por eles, atentatória à ordem geral e à unidade nacional, além de ser promotora da luta de

\footnotetext{
39 Pode-se afirmar que a proposta corporativa vencedora, em especial no que tange ao sistema de representação política fundado em profissões, e ao ideário de união nacional e da primazia do interesse geral sobre os mesquinhos interesses pessoais, foi inspirada no modelo fascista italiano. Dispositivos da Constituição de 1937, assim como da CLT, são cópias textuais de artigos da Carta del Lavoro de Mussolini. A dimensão fascista do corporativismo brasileiro tem sido, entretanto, bastante mitigada por uma série de estudos que apontam particularidades do modelo nacional e o uso pouco comprometido desses dispositivos. Ver, com relação ao tema, RODRIGUES, L.M., 1990.

40 Veja-se, por exemplo, a acalorada defesa do sindicato único que promove Segadas Vianna ao longo de várias páginas em seu O Sindicato no Brasil (1953, p. 32-41).
} 
classes. A unidade de classes e a ordem geral, afirmava-se, imprescindiam da unidade de representação (VIANNA, S., 1953, p. 35).

O propósito de cooperação entre as classes para o progresso do país era igualmente freqüente em discursos e publicações do governo. Novamente, é Segadas Vianna quem ilustra o argumento, ponderando sobre o legado da Era Vargas: "Faltava, entretanto, a presença do Estado, como elemento de conjugação entre o Trabalho e o Capital, orientando de maneira patriótica o proletariado e atuando de forma segura junto à classe empregadora” (VIANNA, S., 1953, p. 146). O problema seria solucionado por Vargas, afirma ele em outro fragmento: "Prestigiando e apoiando a organização sindical, realizava o Estado uma grande obra de dignificação do trabalhador, assegurando-lhe o poder de colaborar diretamente na gestão dos negócios públicos através suas [sic] entidades de classe” (idem, p. 30). O próprio Vargas, em discurso em 1930, manifestara o propósito de que “[...] em vez de atuarem como força negativa hostil ao poder público, deveriam as organizações sindicais tornar-se na vida social elemento proveitoso de cooperação no mecanismo dirigente do Estado” (idem, p. 30).

A cooperação entre classes forjada pela regulamentação e organização do trabalho são respostas, como já demonstrou Heloísa Martins (1989, p. 1), às exigências de maior eficiência e racionalidade para o processo de acumulação capitalista no país que atingiram os dois pólos da produção - o empresário e o trabalhador -, mas também o Estado. Ao assumir a função de direção do processo econômico para impulsionar o desenvolvimento nacional, o Estado necessitava conferir maior racionalidade à sua administração burocrática e às relações sociais de produção. Trata-se de um processo bem descrito pela autora, e antes por Aziz Simão (1966), de crescente burocratização da gestão das relações de trabalho, seja pela intervenção estatal nas mesmas, seja pela profissionalização das lideranças sindicais vinculadas ao modelo corporativo.

Esse intuito de racionalização das relações sociais de produção, para a qual a organização do trabalho é instrumental, é igualmente explícito e ocupa documentos e discursos governamentais. Na exposição de motivos do primeiro documento legal que organiza as associações sindicais (Decreto 19.770, de 19 de março de 1931), o Ministro do Trabalho Lindolfo Collor aponta-o: “Não ponho dúvida em afirmar a V. Excia. que este projeto representa, depois de longas e incompreensíveis vacilações, a primeira iniciativa sistemática no sentido da organização racional do trabalho no país” (VIANNA, S., 1953, p. 25). Segadas Vianna também revelaria esse propósito: “Entendemos que, para beneficiar o 
capital é necessário tornar eficiente o trabalho, e essa eficiência só se obtém melhorando as condições do trabalhador” (idem, p. 39).

A organização do trabalho e a mobilização das classes trabalhadoras para o projeto nacional envolveu uma intensa manipulação cultural, cujas finalidades eram promover o trabalho e a própria figura de Vargas. O trabalho foi elevado a um valor moral absoluto e associado à retidão individual. O vínculo empregatício era reconhecido como a única forma legítima de subsistência e, por isso, uma série de direitos era associada a ele. Em decorrência, a cultura exaltava as qualidades do operário responsável, pontual e obediente e condenava práticas sociais julgadas perniciosas ao trabalho, ainda que manifestações culturais tradicionais da população, e os meios alternativos de subsistência. O intento estatal envolvia a promoção de manifestações culturais alinhadas aos valores da disciplina do trabalho. Marcondes Filho, ao tornar-se Ministro do Trabalho em 1942, passou a fazer amplo uso da Rádio Nacional para proferir palestras sobre a legislação trabalhista (FAUSTO, 2000b, p. 375). Manifestações populares também foram promovidas, igualmente por meio do uso do rádio, atraindo para tanto os mais populares artistas de época e encomendando composições, como O Bonde São Januário, de Wilson Baptista e Ataulpho Alves, imortalizada na voz de Ciro Monteiro e que remetia ao tradicional meio de transporte público no bairro fabril da capital federal para condenar a boêmia:

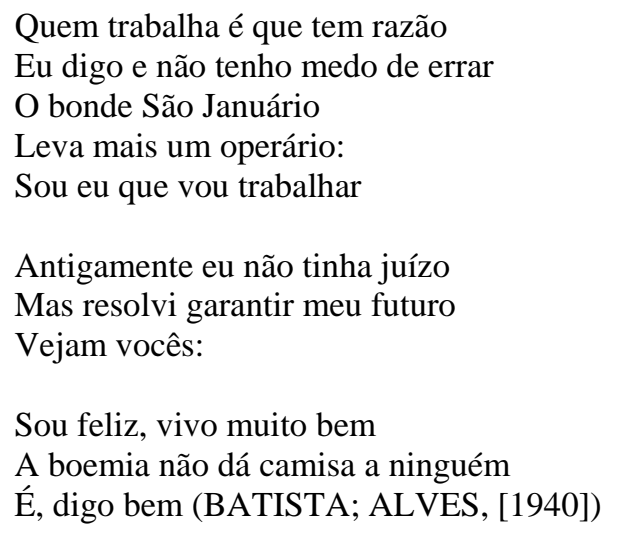

A exaltação moral do trabalho e a concessão de direitos foram, ademais, intimamente associadas à figura pessoal de Vargas. Um amplo aparato cultural foi mobilizado para promover a figura simbólica de Vargas como protetor do trabalhador, governante que por mera liberalidade outorgava direitos e, por essa mesma razão, podia exigir por todos os meios a lealdade e cooperação dos trabalhadores (FAUSTO, 2000b, p. 375). Essa imagem foi empregada por Vargas para construir, junto ao operariado, uma base de legitimidade social para seu regime. A partir de 1939, organizam-se grandes espetáculos 
públicos em comemoração ao dia do Trabalho, em que Vargas, como grande líder, aproveitava os discursos para anunciar inovações na legislação trabalhista.

A legislação trabalhista também foi empregada, como manifestação do nacionalismo getulista, para promover uma modificação da composição da população trabalhadora, formando uma força de trabalho majoritariamente nacional (SIMÃO, 1966, p. 33). Acredita-se que a medida buscava reduzir, assim, a propagação de idéias revolucionárias e o fomento ao movimento operário que era associado aos estrangeiros. Para tanto, foi implementada a lei dos dois terços, limitando o número de elementos estrangeiros nas empresas a um terço de todos os empregados.

\subsubsection{Características e resultados do modelo corporativo}

O sistema brasileiro de regulação das relações do trabalho assumiu, em decorrência da confluência desses elementos, a forma de um modelo corporativista-estatista ou autoritário de intermediação de interesses, na acepção de Schmitter, definido como um

sistema de representação de interesses no qual as unidades constituintes são organizadas em um número limitado ou singular de categorias compulsórias, não-competitivas, hierarquicamente ordenadas e funcionalmente diferenciadas, reconhecidas ou licenciadas (se não criadas) pelo Estado e detentoras de um monopólio representacional deliberado no interior de suas respectivas categorias em troca pela observância de certos controles na seleção de líderes e na articulação de demandas e apoios (1979, p. 13. Traduz-se) $)^{41}$.

Esse modelo de organização dos interesses conjuga, de acordo com Lehmbruch, três características elementares que, embora analiticamente distintas, estão interrelacionadas e o identificam: (1) a formação de organizações centralizadas, representativas dos empregados e dos empregados, detentoras do monopólio da representação de interesses de uma categoria e que ocupam o vértice, ou "pico" do sistema representacional hierarquicamente organizado e integram organizações de nível inferior e menor cobertura geográfica; (2) o acesso privilegiado ao governo conferido a essas associações, materializado na formação de vínculos com a administração pública que podem ser mais ou menos formalizados; (3) e a formalização de uma "parceria social" entre o trabalho

\footnotetext{
${ }^{41}$ No original: "system of interest representation in which the constituent units are organized into a limited number or singular, compulsory, noncompetitive, hierarchically ordered and functionally differentiated categories, recognized or licensed (if not created) by the state and granted a deliberate representational monopoly within their respective categories in exchange for observing certain controls on their selection of leaders and articulation of demands and supports” (SCHMITTER, 1979, p. 13).
} 
organizado e o capital, com a finalidade de regular conflitos e coordenar ações para a consecução de políticas governamentais (1984, p. 61).

No caso brasileiro, outras características, presentes no conceito de Schmitter, estão também presentes: as associações de representação passam a existir a partir do reconhecimento outorgado pelo Estado, “[...] que lhes fixa as modalidades de atuação e relacionamento mútuo, de modo que o funcionamento das 'partes' e suas demandas excessivas sejam contidos e 'harmoniosamente' integrados em benefício de todo o organismo"; além de exercer um controle formal sobre o funcionamento e a seleção de lideranças dessas associações (RODRIGUES, L. M., 1990, pp. 54, 56).

A estrutura desse modelo de organização dos interesses deve permitir uma implementação efetiva de uma política concertada, conjugando-se esforços em torno de objetivos comuns. O êxito na construção desse modelo depende, portanto, de estruturas de agregação, que facilitam entendimentos entre atores, e de mecanismos que garantam a vinculação dos atores aos compromissos alcançados, o cumprimento de suas condições e punam a inobservância (REGINI, 1984). Para alcançar o grau de agregação necessária para facilitar negociações e entendimentos é indispensável restringir o número de participantes, garantindo um acesso seletivo e oligopolista às instituições estatais. Essa condição é alcançada por meio não apenas do monopólio representacional conferido às instituições especialmente as confederações no vértice do sistema - mas também do alto grau de centralização e disciplina na estrutura sindical, como reconhecido por Lehmbruch na primeira característica apontada dos modelos corporativistas. Para garantir o cumprimento das condições do concerto e a disciplina dos atores envolvidos, por sua vez, os arranjos corporativistas devem incluir constrangimentos institucionais que controlem os atores, evitem dissidências e punam a inobservância. Ademais, deve-se impossibilitar a expressão de interesses ou atores à margem do arranjo, o que o invalidaria (REGINI, 1984).

Além de requisitos organizacionais, os arranjos corporativistas demandam uma visão particular da sociedade, compartilhada por diversas ideologias existentes na primeira metade do século XX. Assumindo a existência de conflitos, os atores políticos envolvidos na construção de modelos dessa natureza possuem uma incontestável confiança no Estado como garantidor da ordem social por meio do patrocínio de contratos bilaterais. Essa concepção associa-se a valores políticos paternalistas, mas também com uma nova visão burocrática do Estado como o principal ator do planejamento econômico (LEHMBRUCH, 1984). Sobretudo, essa particular concepção das funções do Estado estava associada a 
projetos de modernização econômica e social, para os quais se julgava necessário conjugar esforços de todos os grupos sociais e criar uma estrutura de coordenação entre o corpo tecnocrático e interesses corporativos para administrar as atividades econômicas (MAIER, 1984, p. 46; LEHMBRUCH, 1984, p. 63).

O Brasil não era exceção a esse quadro geral de valores políticos e visões de Estado que subjazem à montagem de aparatos corporativistas. Embora produto de um governo autoritário e nacionalista, o corporativismo foi estruturado no Brasil não por uma elite tradicional com pensamento conservador, mas por um grupo com preocupações modernizantes (RODRIGUES, L. M., 1990, p. 56). O modelo assume, no país, o caráter de uma força modernizante e racionalizadora, capaz de reduzir os conflitos sociais e acomodar interesses e, por isso mesmo, absolutamente compatível com as propostas tecnocráticas e positivistas. Os vínculos estabelecidos entre os sindicatos e o Estado implicam uma nova forma, altamente racionalizada, de relações entre as classes e dessas com o Poder Público (SIMÃO, 1966, p. 2), orientadas para a pretendida colaboração em torno de um projeto nacional de acumulação.

Uma importante distinção separa o aparato brasileiro de regulação dos interesses econômicos porém, do modelo teórico de corporativismo, construído a partir da análise de arranjos europeus. Uma característica freqüentemente associada ao corporativismo é a existência de um intercâmbio político entre classes, a partir do qual se constrói o concerto. Em troca da ordem na produção, empregados recebem benefícios, tais como maior participação no governo, direitos ou emprego estável (MAIER, 1984). Esse intercâmbio, porém, não ocorreu no Brasil, já que o aparato corporativista não resultou de um legítimo pacto social resultante da negociação entre capital e trabalho, isto é, não foi o "resultado de acordos negociados entre o Estado, as grandes corporações capitalistas e os sindicatos”, produzindo uma forma de compromisso de classe que mantém a estabilidade, como Bottomore descreve o sistema de capitalismo gerenciado, ou corporativista (1992, p. 59) ${ }^{42}$.

Estabelecido autoritariamente, sem a participação ou consulta popular, não representava os anseios da massa trabalhadora, que apenas pretendia, como haviam demonstrado as greves do final da década de 1920, a ampliação da cidadania por meio da concessão de direitos e de melhores condições de trabalho. Com efeito, havia quem, no meio operário, pretendesse a colaboração de classes e a proteção do Estado mediante a

\footnotetext{
${ }^{42}$ No original: "product of agreements negotiated between the state, the large capitalist corporations and the trade unions, and some kind of 'class compromise' is reached in order to maintain stability" (BOTTOMORE, 1992, p. 59).
} 
inserção nos quadros burocráticos e fixação de direitos para que ação sindical pudesse se dar de modo legítimo e ordeiro (FAUSTO, 2000a, p. 53). O sindicalismo pragmático, ou moderado, como foi denominado, apressou-se em colaborar com o novo regime e a se incorporar na estrutura burocrática trabalhista. Entretanto, como não interessava às agremiações operárias mais combativas o modelo centrado no Estado, o mesmo foi alvo de forte resistência de lideranças sindicais ligadas aos movimentos anarquistas, e mais tarde da Aliança Libertadora Nacional, violentamente reprimida.

Essa distinção, contudo, parece ser menos relevante do que parece à primeira vista. A legítima concertação social verificada nos governos social-democratas no pós-Segunda Guerra, ainda que representasse interesses dos trabalhadores, não possuía orientação rigorosamente distinta. Em primeiro lugar, porque nesses também servia para assegurar a reprodução social que, aliás, parece constituir a função precípua do welfare state. Em segundo, porque também constituiu uma fórmula de institucionalização do conflito entre classes e de forjamento de um consenso, patrocinado pelo Estado, para garantir a acumulação em bases capitalistas, como amplamente reconhecido pela literatura (OFFE, 1984, p. 373; BOYER; SAILLARD, 2002, p. 37). Em terceiro lugar, porque mesmo no Brasil houve atendimento a algumas reivindicações apresentadas no período anterior à revolução, ainda que simbolicamente por vezes, pelo novo governo: o Decreto-lei 17.604 de 1931, por exemplo, punia fraudes e adulterações nos gêneros alimentícios, uma antiga reivindicação da população que sofrera, em meio à carestia das primeiras décadas de século, com o oportunismo dos comerciantes. Algumas práticas econômicas, ademais, foram criminalizadas pelo Decreto-lei 869 de 1938.

A construção desse modelo exigiu a mobilização dos três poderes. Foi necessário criar um órgão no Executivo para lidar com as questões do trabalho, o que foi feito nos primeiros meses do governo provisório, em 1931. O Ministério do Trabalho era criado como uma instância burocrática estatal dirigida à regulação e fiscalização das relações de trabalho e da organização dos trabalhadores. Para organizar as suas entidades de representação e disciplinar as condições de comercialização da força de trabalho foi necessária, ademais, a edição de sucessivos diplomas legislativos. A organização do conflito dependia, ainda, da criação de uma forma racional de processamento dos conflitos que reduzisse seus potenciais danos para a produção. Para tanto foi criada a Justiça do Trabalho, uma instância de arbitramento exclusivo dos conflitos individuais e coletivos surgidos a partir das relações formais de emprego. 
Por meio dessa legislação e da nova estrutura administrativa especializada, realizase uma ordenação jurídica das relações de trabalho e da ação sindical, reconhecida e incorporada à estrutura. Opera-se, ademais, uma publicização da relação jurídica de trabalho, que até então era de direito privado: desde 1916, vigia a liberdade contratual absoluta para a compra e venda de trabalho assalariado, que era regulamentada pela figura da locação de serviços, presente no Código Civil. A partir da Consolidação das Leis do Trabalho, de 1943, cria-se um contrato exclusivo para a relação de emprego, compreendida como a prestação de serviços de modo habitual e subordinado mediante salário ( $\operatorname{art.} 3^{\circ}$ ), cujas condições de execução são minuciosa e coletivamente normatizadas ${ }^{43}$.

A produção legislativa trabalhista e sindical foi intensa no período, seguindo as alterações de rumo do governo Vargas, mas sempre manifestando a preocupação com a ordem e a paz social (MARTINS, 1989). Vale destacar, portanto, apenas os documentos e orientações institucionais que imprimiram ao modelo de regulação jurídica e organização das relações de trabalho suas características mais significativas ${ }^{44}$.

Durante toda a década de 1930 houve a produção de uma extensa legislação que se ocupava de regular aspectos específicos da relação de trabalho ou aplicava-se a categorias profissionais singulares. Datam do período leis que limitavam o trabalho dos menores, estabeleciam a equiparação salarial entre sexos, garantiam férias, adicional noturno, fixavam a jornada semanal de trabalho, o repouso semanal remunerado e o horário de funcionamento dos comércios.

No feriado do $1^{\circ}$ de maio de 1940, por meio do Decreto-lei 2.162, o governo cumpriu a antiga promessa de estabelecer um salário mínimo normativo, que constituía o piso nacional e os regionais para a remuneração dos trabalhadores. A fixação do valor deveria observar o mínimo necessário para a subsistência, somando-se o custo dos gêneros de primeira necessidade. A partir do estabelecimento do salário mínimo, os sindicatos passaram a estabelecer, com o apoio do Ministério do Trabalho e por meio de negociações coletivas, salários profissionais, pisos salariais que valiam para os trabalhadores de uma categoria.

\footnotetext{
43 Não há consenso, na doutrina jurídica trabalhista, a respeito da natureza - pública ou privada - do direito do trabalho. A questão é antiga e produziu já diversos tratados, dentre os quais se destaca o de Cesarino Junior, célebre por sua solução inovadora, tratando o direito do trabalho como direito social, um tercius genus, portanto. Puramente conceitual, a celeuma não tem maiores conseqüências para o presente estudo. Contudo, não há como negar que, ao criar uma figura contratual amplamente regulada pela legislação, deixando às partes reduzido espaço para a negociação, a CLT transformou o contrato de emprego em uma figura bastante distinta dos tipos contratuais clássicos do direito privado.

${ }^{44}$ Uma lista completa da legislação social do período pode ser encontrada em Simão (1966, p. 90-98).
} 
Até a sistematização e ampliação dessas leis na Consolidação das Leis do Trabalho (CLT), em 1943, as categorias profissionais gozavam de direitos diferenciados, reflexo da natureza da atividade laboral, do prestígio social, do peso específico na estratégia governamental de promoção de desenvolvimento e manutenção da ordem, da proximidade com o regime e das habilidades de promover seus interesses junto ao Estado. A CLT, esforço racionalizador empreendido por competentes técnicos do Ministério do Trabalho, como Arnaldo Sussekind e Segadas Viana, estabeleceu normas regulando disposições válidas para todos os empregados, categoria formal de trabalhador, e estabeleceu padrões gerais regulando os contratos individual e coletivo (acordos e convenções coletivas) de trabalho, os sindicatos, a Justiça do Trabalho e seu processo. Entretanto, continuou a consagrar os privilégios de algumas ocupações, ao manter dispositivos especiais válidos especificamente para algumas categorias.

A Justiça do Trabalho, instância de arbitramento dos conflitos originados das relações de trabalho e da ação sindical originou-se das juntas de conciliação e julgamento estabelecidas pelo Decreto 21.396, de 12 de maio de 1932. Sua criação inseria-se, com efeito, no processo de racionalização burocrática que caracteriza a organização do trabalho e da administração para geri-lo. Se produzido um direito especial com uma figura contratual própria para o trabalho, não fazia sentido subordinar sua fiscalização e execução à Justiça Comum. A reorganização das juntas para a formação da Justiça do Trabalho, pelo Decreto-lei 1.237 de 2 de maio de 1939, pretendia conferir maior eficiência ao procedimento de solução de controvérsias trabalhistas e sistematicidade à estrutura do órgão jurisdicional, além de torná-lo consentâneo com a estrutura corporativista e o forte controle sindical, ambos consagrados na Constituição de 1937. Nesse sentido, agregavamse a essa Justiça especializada membros da burocracia sindical, que passariam a ocupar o cargo de juiz classista e participar ativamente da solução dos dissídios, como forma de ampliação da legitimidade da decisão.

Ao estabelecer procedimentos judiciais específicos para a administração de conflitos coletivos envolvendo trabalhadores e empregadores, a Justiça do Trabalho mostrou-se um importante mecanismo de controle administrativo e racionalizador da ação sindical. O dissídio oferecia um procedimento racional e relativamente eficiente de administração de conflitos, já que minimizava os riscos de interrupção da produção. Ademais, a substituição dos conflitos abertos pelos dissídios coletivos na Justiça do Trabalho contribuiu com a fragmentação dos interesses operários promovida pela estrutura 
sindical, adiante analisada, ao restringir a legitimidade ativa aos sindicatos setoriais oficialmente reconhecidos, e limitou as possibilidades de expressão dos interesses e de direcionamento de conflitos. A obrigatoriedade do emprego do procedimento judicial previsto em lei confina os conflitos e demandas encaminhadas por trabalhadores aos estreitos limites do que é juridicamente reconhecido. O dissídio é duplamente limitador, já que restringe a forma de expressão do conflito ao exigir a observância de um procedimento formal e o conteúdo da demanda. Exige-se que a demanda, assim como o fundamento da solução do conflito, esteja nos limites da lei trabalhista, já que o dissídio representa a submissão a um exame de legalidade das pretensões, não cabendo um exame sobre a legitimidade ou pura razoabilidade da demanda.

Outro elemento fundamental para compreender o modelo corporativo e seus efeitos sobre o desempenho da ação sindical, é a legislação que se ocupou da organização dos sindicatos no país e da regulação de suas atividades. Não tardou muito para que o governo revolucionário reconhecesse as organizações sindicais. No início de 1931, o Ministro Lindolfo Collor apresentou o que se converteria no Decreto-Lei 19.770, de 19 de março daquele ano, regulamentando a organização e o funcionamento das associações profissionais, patronais e operárias.

O documento reconheceu os sindicatos como órgãos coletivos e de colaboração com o poder público. Para a consecução dessa imaginada colaboração de classes, instituiu mecanismos de controle da ação sindical, permitindo a presença de representantes do governo no interior das associações, além de estipular os três pilares do modelo corporativo brasileiro: a unicidade sindical, a obrigatoriedade de reconhecimento do Ministério do Trabalho para o funcionamento e a liberdade de associação. A unicidade determinava a existência de um único sindicato, por categoria, por unidade territorial. Desse modo, cada categoria, profissional e empresarial, reconhecida pelo Estado, era representada por uma única organização na estrutura corporativa. Como apontado, identificava-se com a idéia de unidade nacional em torno dos interesses do Estado.

O mecanismo de reconhecimento sujeitava a existência jurídica das associações sindicais a uma autorização do Estado que incluía sua adequação à legislação vigente e, indiretamente, à manutenção da ordem. Ainda que a negação por razões políticas pudesse ser inconveniente, o Estado podia impedir a existência de uma associação que considerasse nociva à paz social por meio da alegação da ausência ou irregularidade de um requisito formal que a lei estabelecia para a constituição de um sindicato. A existência das instâncias 
de agregação e representação dos interesses e mesmo de organização da ação coletiva dos trabalhadores sujeitava-se, desse modo, não apenas à racionalidade legal, mas indiretamente ao beneplácito do Estado.

A liberdade de associação nos sindicatos, último dos aspectos implementados, determinava ser a associação aos sindicatos uma faculdade, e não uma obrigação. Nesse momento inicial, a associação livre dos trabalhadores aos sindicatos ainda não interferia no desempenho da ação sindical, porque era compensada por fortes incentivos à filiação e porque não estava associada a outros mecanismos institucionais e jurídicos. Até a Constituição de 1934, apenas os sindicalizados podiam apresentar reclamações trabalhistas perante a Justiça (Decreto 22.132, de 25 de novembro de 1932) e gozar de férias (Decreto 23.768, de 18 de janeiro de 1934). Mesmo após sua promulgação, momento em que se revogaram essas disposições por se considerá-las inconstitucionais, a legislação exigia a filiação efetiva ao sindicato para a aplicação individual da convenção coletiva da categoria (Decreto 24.694, de 12 de julho de 1934). A liberdade de associação já servia, porém, para reforçar uma retórica liberal e de proteção aos genuínos interesses dos trabalhadores.

Com a Constituição de 1934, o controle estatal sobre os sindicatos foi relativizado e garantida certa margem de autonomia. O artigo 120 reconhecia a função dos sindicatos e estabelecia o direito de reconhecimento às entidades nacionais. $\mathrm{O}$ dispositivo, regulamentado pelo Decreto 24.694, de 12 de julho de 1934, modificava o modelo anterior ao possibilitar a pluralidade sindical, isto é, a existência de mais de um sindicato por categoria em cada localidade. Além disso, embora o sindicato ainda tivesse que se sujeitar aos padrões legais e organizativos esperados para ser reconhecido pelo Ministério do Trabalho, as intervenções foram controladas e o fechamento dos sindicatos não podia superar o prazo de seis meses.

No entanto, funcionários do governo entenderam que as novas atribuições dos sindicatos, exigindo a sua proximidade com o Estado, eram incompatíveis com o regime de ampla autonomia que lhes foi conferida (VIANNA, S., 1953). Por essa razão, a próxima alteração legislativa reforçou o modelo sindical centrado no Estado. Foi com o golpe de 1937 e a Constituição do mesmo ano que Vargas logrou completar a montagem do edifício corporativo de representação de interesses e organização do trabalho. O artigo 138 da Carta imposta no Estado Novo determinava de modo claro o papel que o regime esperava ser desempenhado pelos sindicatos, promovendo a ordem e a colaboração com os interesses do Estado. Trata-se do momento de maior incorporação das entidades à estrutura estatal, de 
modo a quase se confundir com essa: os sindicatos são transformados em "órgãos paraestatais” (VIANNA, S., 1953), e sua atividade reconhecida como função pública delegada. Mantém-se a exigência de reconhecimento estatal para existência dos sindicatos como pessoa jurídica e interlocutor, ainda que a liberdade de formação de sindicatos fosse proclamada, e também a liberdade de filiação sindical. A unicidade sindical, ademais, é restabelecida.

A Constituição de 1937 sufocava, por completo, as possibilidades de ação coletiva autônoma. Até ser outorgada, a despeito do controle sobre os sindicatos e do processamento dos conflitos trabalhistas por meio dos dissídios judiciais, a greve ainda era uma possibilidade e constituía o principal instrumento de reivindicação política por parte dos trabalhadores (MARTINS, 1989, p. 25). O Estado Novo não apenas proibiu as paralisações da produção, como ainda determinou respostas duramente repressivas contra quaisquer manifestações de interesses externas ao modelo corporativo. A greve era proibida, pelo texto constitucional, como expressão do compromisso da organização do trabalho com os interesses da produção nacional (art. 139). Como era contrária a esses interesses, não podia ser tolerada.

Com efeito, em nenhum momento desde o movimento revolucionário de 1930 a repressão foi abandonada como resposta à ação coletiva. Todas as manifestações de trabalhadores realizadas além dos limites legais da estrutura corporativa e dos meios institucionais de processamento dos conflitos - Justiça do Trabalho - eram reprimidas com o violento aparato policial criado por Vargas. Foi no Estado Novo, porém, que a repressão tornou-se novamente a forma predominante de gestão dos conflitos, superando as relações harmoniosas entre Estado e operariado.

A Constituição de 1937 foi regulamentada por sucessivos decretos-lei, em que se disciplinou a livre associação em sindicatos e a organização da estrutura sindical vertical (Decreto-lei 1.402, de 5 de julho de 1939), o enquadramento sindical das profissões (Decreto-lei 2.381, de 9 de julho de 1940) e a arrecadação da contribuição sindical obrigatória e sua repartição com as federações e a confederação (Decretos-lei 2.377/40 e 4.298/42). A estrutura criada pelo decreto de 1939 organizava os sindicatos estaduais em torno de uma federação estatal. No caso dos empresários, criavam-se também confederações nacionais para cada um dos três setores da economia (agricultura, indústria e comércio). O enquadramento sindical, por sua vez, era a decorrência lógica do reconhecimento estatal das ocupações que devia, no sistema getulista, anteceder à 
autorização para constituição dos sindicatos e a concessão de direitos relacionados à proteção do trabalho. Todas as ocupações reconhecidas pelo Estado deviam estar inseridas em uma categoria profissional, a qual servia de base para a constituição dos sindicatos. Em 1942, a CLT reuniu a legislação anterior sobre os sindicatos em seu Título V, consagrando esses mesmos princípios norteadores da constituição e funcionamento dos sindicatos, incluindo a unicidade ${ }^{45}$ e o enquadramento sindicais ${ }^{46}$.

A criação do imposto sindical desferiu o último golpe da Era Vargas contra a possibilidade de mobilização dos trabalhadores a partir dos sindicatos. Para garantir os fundos necessários ao funcionamento do sistema de sindicato único reconhecido pelo Ministério do Trabalho, a legislação (CLT, art. 579) criou uma contribuição sindical compulsória, exigida de todos os assalariados registrados da categoria, independentemente de seu envolvimento com o sindicato ${ }^{47}$. A um só tempo, o sistema representou a subordinação completa do sindicato ao Estado, de quem dependia para sua sustentação, e determinou uma acomodação das lideranças sindicais que muito contribuiu para sua transformação em um corpo burocrático (MARTINS, 1989). Ao garantir a contribuição de todos os profissionais da categoria independentemente da sua associação efetiva ao sindicato, tornou desnecessária a atração da base trabalhadora, mediante a conquista de benefícios, para disputar recursos. A subsistência da estrutura sindical e de seus cargos estava garantida mesmo diante de sua completa inação.

Completava-se, assim, a construção do edifício jurídico que organizava o trabalho e sua ação coletiva segundo moldes corporativistas, assegurando as regras para entrada no sistema, a formação das relações hierárquicas entre as associações e a base de financiamento das atividades. O processo de legitimação e disciplina legal das agremiações operárias conferiu-lhes estabilidade, mas as sujeitou ao controle estatal. A estrutura regulatória do trabalho no interior do Estado atraiu os líderes sindicais, transferindo as decisões sobre os rumos e possibilidades da ação coletiva operária para o aparato estatal.

\footnotetext{
${ }^{45} \mathrm{O}$ art. 516 da CLT dispõe: "Não será reconhecido mais de um sindicato representativo da mesma categoria econômica ou profissional, ou profissão liberal, em uma dada base territorial”.

${ }^{46} \mathrm{O}$ art. 570 da CLT assim disciplina o enquadramento sindical: “Art. 570. Os sindicatos constituir-se-ão, normalmente, por categorias econômicas ou profissionais, específicas, na conformidade da discriminação do quadro das atividades e profissões a que se refere o art. 577 ou segundo as subdivisões que, sob proposta da Comissão do Enquadramento Sindical, de que trata o art. 576, forem criadas pelo ministro do Trabalho, Indústria e Comércio” (destaca-se).

${ }^{47}$ A contribuição sindical é recolhida anualmente e corresponde à remuneração por um dia de trabalho para os empregados, (CLT, art. 580), descontada da folha de pagamento referente ao mês de março pelo empregador (art. 582). A arrecadação resultante da contribuição sindical é distribuída da seguinte forma (art. 589): confederações recebem 5\%, federações 15\% e, desde 1976, $20 \%$ são depositados na "conta especial emprego e salário”. Aos sindicatos cabem os restantes $60 \%$.
} 
A partir da Constituição de 1937, esse processo intensificou-se e os sindicatos tornaram-se estruturas burocráticas indistintas do Estado. Além de integrar o aparato, tanto no Executivo, quanto na Justiça do Trabalho, suas reivindicações e propostas confundiamse com os interesses estatais. Passam a reproduzir perante a sociedade e suas bases discursos alinhados ao projeto nacional de desenvolvimento, que interessava antes ao capital nacional, insurgindo-se contra a participação estrangeira na economia brasileira e defendendo maiores poderes do Estado sobre os negócios (SIMÃO, 1966, p. 38).

Os sindicatos tornam-se, portanto, meros braços de uma possível relação entre o Estado e os trabalhadores, o que tampouco ocorrerá. A colaboração e a participação equânimes das classes trabalhadora e capitalista defendidas na proposta de Vianna permaneceram no plano da retórica (COSTA, V. M. R., 1991). Esses discursos assumiam uma função de dissuasão dos conflitos e de negação da existência de uma luta de classes. Serviam, ademais, para alçar os interesses nacionais - a acumulação por substituição de importações - ao primeiro plano e orientar todos os esforços individuais para sua consecução. Contudo, a edificação de um modelo de representação formal dos interesses dos operários não representou sua participação ou acesso às decisões políticas. Como resultado das concessões feitas à elite industrial, foi negada a possibilidade de criação de confederações operárias, limitadas e proibidas as greves e criados espaços de participação exclusiva para o empresariado no interior da administração.

A estrutura corporativa não serviu, sequer, para abrir um canal de manifestação, no interior do Estado, das pretensões operárias: os sindicatos geravam uma mera ilusão de representação, já que as lideranças vinculadas à estrutura corporativa, em seu processo de burocratização, não vocalizavam interesses da classe e limitavam-se a proceder a tarefas cotidianas de administração da organização do trabalho e solução controlada e racional dos conflitos. Ao transformar as lideranças sindicais em burocratas, integrantes do oficialato do Ministério do Trabalho, o aparato regulatório convertia também os sindicatos em instrumento do Estado. As atividades sindicais passam a orientar-se pelos fins da burocracia estatal, e não pelos de quem deveria representar, os trabalhadores. Não existindo a possibilidade de manifestações ou ações sindicais no exterior da estrutura estatal, as agremiações teriam de se limitar à execução 
assembléias para votação e aprovação de greves, concessão de bolsas de estudos para filhos de trabalhadores, além das atividades médica, hospitalar e farmacêutica (MARTINS, 1989, p. 116-7).

Pode-se apontar ainda, nesse contexto, uma verdadeira oligarquização dos setores operários incorporados à administração pública pela sua participação na estrutura oficial de representação. Opera-se para as entidades de representação operária, pelo modelo corporativo brasileiro, a lei de ferro que Michels descrevera para os partidos de massa e os privilégios conferidos a essas lideranças transformam-na em um verdadeiro estamento burocrático, um setor protegido e destacado da classe operária (OLIVEIRA, F., 2006, p. 146). A contraprestação lógica pelo reconhecimento dessas lideranças e concessão de benefícios políticos e econômicos é a vinculação e comprometimento cada vez mais intensos com os interesses do Estado, em detrimento dos anseios das bases distanciadas.

Em suma, o aparato corporativista de regulação das relações do trabalho, por meio da CLT, da Justiça do Trabalho e do controle, enquadramento e subordinação dos sindicatos ao Ministério do Trabalho, opera uma organização racional das relações do trabalho que limita os procedimentos disponíveis para a expressão e canalização dos conflitos trabalhistas e a forma de organização dos atores em sindicatos (racionalização formal), assim como o conteúdo material das lutas operárias (racionalização material), ao restringi-las a direitos reconhecidos em lei ou a demandas menores, particulares a grupos de trabalhadores e capazes de serem processadas pelo sistema de administração de conflitos.

Ao aceitar as condições racionais-legais de processamento institucional dos conflitos, que incluem a mediação estatal e o enquadramento legal das ações e dos atores, os trabalhadores e seus sindicatos têm sua capacidade de articulação e expressão limitadas por padrões normativos impostos pelo aparato de regulação. Esses limites traduzem, em termos formais, a subordinação da ação organizada dos trabalhadores à finalidade, determinada pelo Estado, de organização racional das relações sociais de produção. Isso representa dizer que a expressão dos interesses do trabalho passam a guiar-se heteronimamente, por imperativos racionais de previsibilidade na manifestação e gestão dos conflitos. A racionalização impõe-se como uma jaula de ferro, definindo os contornos no interior dos quais os trabalhadores podem mover-se e subtraindo-lhes a capacidade de definir autonomamente os rumos de sua luta.

Os produtos empiricamente verificados desse modelo são a redução do potencial combativo dos trabalhadores, a despolitização da ação sindical e do conflito trabalhista e 
uma conseqüente transformação da pauta de reivindicações, cujo conteúdo torna-se predominantemente econômico, girando em torno de alguns direitos que lhes garanta condições básicas de subsistência. Os obstáculos policiais e administrativos tornaram as ações mais combativas dos sindicatos episódios isolados. O aparato de regulação oferecia limites procedimentais e materiais às demandas dos trabalhadores e impedia manifestações no exterior da estrutura oficial, controlada pelo Estado. Ademais, a organização setorial e local de sindicatos dificultava a agregação de interesses e a produção de uma unidade que superasse as categorias em que se dividira o movimento operário. A abundância de legislação produzida para regular as relações do trabalho também restringia a ação sindical, já que toda a matéria legislada, fixando condições de execução do contrato de trabalho de modo geral e abstrato, é subtraída do campo de negociação sindical.

Refletindo em suas memórias sobre o legado da Era Vargas para a ação coletiva operária, assim resumia o militante sindical Everardo Dias em $1962^{48}$ :

[...] o Sindicalismo criado à sombra do governo, orientado num sentido demagógico e falso, corruptor e opressor, tendo à sua frente indivíduos sem tradição proletária, ambiciosos e pouco escrupulosos em sua maioria, intoxicou o proletariado nacional. [...] o espírito de solidariedade que outrora era tão pronunciado nos trabalhadores, aquela refletida dignidade, aquela altivez consciente quase desapareceu nos indivíduos, obliterando-lhes a condição de classe e despreocupando-os de sua emancipação coletiva [...] (1977, p. 214).

O legado que atribui ao governo de Vargas é válido, aliás, para o modelo corporativista como um todo e suas reflexões permaneceram pertinentes até a crise desse modelo, como se verá adiante.

Antes de passar à análise do período subseqüente, é imperioso reconhecer que o modelo corporativista, pela incorporação das organizações sindicais e segregação do movimento operário em função das categorias profissionais, não logrou evitar por completo as possibilidades de práticas obreiras mais combativas e tampouco evitou a

\footnotetext{
${ }^{48}$ Muito embora reconhecesse o efeito deletério da política trabalhista sobre a formação de uma consciência de classe entre o operariado, Dias julgava algumas das iniciativas de Vargas positivas e as compreendia como um avanço em relação ao quadro institucional anterior. Em especial, destacava a melhoria das condições de trabalho, a conquista de direitos como uma curta licença para as gestantes e as aposentadorias, além do declínio do controle ostensivo e violentamente repressivo praticado pelas autoridades e no interior das fábricas. O líder operário Everardo Dias nasceu em Pontevedra, Espanha, em 1883. Transferiu-se para o Brasil quando tinha apenas dois anos de idade. Foi preso e deportado em 1919, após participação em uma greve na capital paulista. No ano seguinte retornou ao Brasil e fundou em 1921 o Grupo Clarté do Brasil, "organização que reunia operários e intelectuais simpáticos às teses da Revolução Russa”. Foi novamente preso sob a presidência de Artur Bernardes, acusado de conspiração. Faleceu em 1966, em São Paulo (Dicionário Histórico-Biográfico Brasileiro, 2008).
} 
eclosão de conflitos coletivos que, no entanto, passaram a ser solucionados pela intervenção da Justiça do Trabalho. Ainda que tenha produzido um padrão racional de ação sindical orientado para a ordem necessária à acumulação, e proibido ações operárias no exterior desse padrão, consagrado no esquema oficial de representação, trabalhadores dos grandes centros urbanos continuaram a promover greves, mesmo no período de maior repressão, durante os anos de Estado Novo. Aziz Simão apresenta dados que apontam uma queda pouco significativa, de pouco mais de 20\% (de 116 para 90) no número de greves no Estado de São Paulo no período de 1930-1940, quando comparado com o período 19151929, anterior à revolução, de grande agitação operária (1966, p. 139, 142).

\subsection{5-1964: O intervalo democrático}

No curso da guerra e nos anos que a sucederam, pela concentração das nações industriais avançadas no esforço de guerra e o conseqüente desabastecimento de produtos manufaturados, o processo de industrialização teve no país seu ritmo acelerado de modo expressivo, assim como o crescimento da população ocupada (SIMÃO, 1966, p. 15) ${ }^{49}$. Esse é, também, o período em que a atividade industrial supera a contribuição da agricultura para o produto interno nos estados industriais e a produção industrial ganha centralidade no planejamento econômico do Estado (idem, p. 18, 40). Além de ser produto da boa conjuntura internacional, em que o produto nacional encontrava mercados fáceis no exterior e baixa concorrência no mercado interno, é razoável supor que a notável acumulação promovida pelo crescimento industrial era também o resultado da maturação dos investimentos realizados em infra-estrutura e do início da construção de um parque industrial de bens de produção, fundamentais para o crescimento fabril nacional.

Além de transformações quantitativas no período, a indústria e com ela o perfil ocupacional do operário também passariam por alterações qualitativas. Em termos setoriais, a indústria mecânica e de material elétrico superaram a têxtil como principal

\footnotetext{
49 Aziz Simão assinala que na segunda metade da década de 1940 o crescimento do número de estabelecimentos industriais foi o triplo do verificado na primeira metade (12.261 entre 1945 e 1949 , e 4.412 entre 1940 e 1944). No segundo qüinqüênio da década, o número médio de novos estabelecimentos chegaria a aproximadamente 2.500, sendo que no primeiro qüinqüênio foi de cerca de 900 e na década anterior, de 500. No que diz respeito ao aumento da população ocupada, foi de 120 mil pessoas na segunda metade da década de 1940 e de 184 mil no qüinqüênio seguinte (1950-1954), correspondendo a médias anuais de 24 e 35 mil pessoas respectivamente. Entre 1933 a 1937 a média anual de novos trabalhadores não passava de 1000 (1966, p. 15).
} 
atividade. Ademais, há uma expressiva ampliação da indústria de base, produtora de insumos metálicos e de maquinário, sob a coordenação e, em certos casos, pela atividade direta do Estado na economia. De um modo geral, a indústria tornava-se mais complexa, com o incremento da variedade de produtos e componentes e a crescente especialização das tarefas desempenhadas no interior da fábrica, dos setores e dos estabelecimentos produtivos (SIMÃO, 1966, p. 16-7). Simultaneamente, há um processo de concentração da indústria e do capital (idem, p. 37), consentânea com o projeto governamental que, conforme apontado, julgava constituir essa a estrutura industrial mais eficiente para o desenvolvimento nacional.

Indubitavelmente esses processos afetaram os sindicatos e, mais genericamente, a ação coletiva operária. A concentração industrial nos centros urbanos do Sudeste gera um rápido crescimento do operariado industrial nessas áreas e facilita sua articulação e mobilização. No entanto, o modelo corporativo de intervenção social cuja construção fora iniciada na Era Vargas sobreviveu à redemocratização, bem como suas determinações sobre a ação coletiva. Em grande parte do período o sindicato é ainda empregado como peça-chave de colaboração com o projeto de acumulação pela substituição de importações.

O complexo ideológico que sustentava o corporativismo logra reproduzir-se com a criação de uma burocracia própria, que envolvia o Ministério e a Justiça do Trabalho, os Institutos de Aposentadorias e Pensões e a estrutura sindical. Há, ademais, categorias privilegiadas pelo esquema e que, por isso mesmo, lutam pela sua manutenção. Em especial, o corporativismo e sua burocracia representaram oportunidades para dois estratos sociais: para as camadas médias e para representantes empobrecidos da velha oligarquia rural. Para as camadas médias urbanas, representou uma possibilidade de ascensão social. Os salários e a proteção conferida aos funcionários públicos atraem, até os dias de hoje, os setores urbanos educados. Para as elites oligárquicas tradicionais, decadentes e enfraquecidas pelo modelo de desenvolvimento industrial, constituiu uma oportunidade de manutenção de prestígio (RODRIGUES, L. M., 1990, p. 64). Nesse sentido, a despeito da retórica modernizante e racionalizante da administração, as nomeações para o exercício de cargos públicos continuaram a obedecer a uma lógica clientelista e serviram como um instrumento do regime para a atração da lealdade da velha oligarquia alijada.

Ademais, a reprodução da máquina corporativa após 1945 foi assegurada, como assinala Martins Rodrigues (1990, p. 52), porque a mesma se constituiu como o único meio de reforçar a representação, alternativa à tradicional instância legislativa. No período de 
Vargas, o Legislativo funcionou apenas excepcionalmente e após a redemocratização, o rearranjo de forças que se processava era causa de uma incapacidade sustentada de processar reivindicações, aprovar reformas (CARVALHO, 2004) e controlar a máquina burocrática (RODRIGUES, L. M., 1990, p. 62). Esses problemas verificados no Legislativo também explicam, portanto, a impossibilidade de aprovação das reformas essenciais para a continuidade do projeto nacional desenvolvimentista, que incluíam alterações na regulação do trabalho.

A despeito da manutenção da estrutura sindical corporativa, o período é pródigo para a ação coletiva sindical. A Constituição de 1946 restabeleceu o direito de greve e reduziu os controles antes exercidos sobre os sindicatos. Desse modo, após a forte repressão a todas as formas de ação autônoma que marcara o período anterior, assistiu-se a uma expressiva politização dos movimentos sociais, inclusive daqueles vinculados aos interesses dos trabalhadores, que pôde florescer às margens dos interesses e da estrutura estatal pelo declínio do controle estatal e pela restauração das liberdades democráticas (MARTINS, 1989).

Esse contexto, em que se conjugam a incapacidade do governo de articular soluções negociadas para processar as demandas populares e das elites com o afrouxamento dos controles estatais sobre a ação social, auxilia a compreender a crescente agudização dos conflitos na década de 1960 e o surgimento de um movimento rural mais significativo. Entre os trabalhadores urbanos, os conflitos explicam-se, mais uma vez, pela perda do poder de compra em um ambiente inflacionário e de redução dos salários reais. Mas a difusão de idéias e os debates em torno dos programas de reformas para o país propostos no período constituem igualmente uma razão para a manifestação em defesa de uma via mais participativa e popular para o país.

Soma-se, ainda, para explicar a maior vazão dos movimentos sociais no período, o agravamento das condições de vida nos centros urbanos, que experimentavam rápido crescimento e, com ele, também se ampliavam problemas vinculados à habitação, saneamento e saúde. Ao manter a mesma estrutura de intervenção social, o Estado mostrava-se incapaz de lidar com esses novos conflitos, que surgiam à margem da legislação (SANTOS, 1989, p. 74).

No campo também se verificaria, no período, um incremento da expressão dos conflitos sociais. É nesse período que a população rural inaugurou sua participação como ator coletivo, promovendo os primeiros movimentos de repercussão nacional. O 
surgimento da ação coletiva no campo não pode ser confundido, entretanto, com a afirmação comum de que, até então, os trabalhadores rurais não haviam recebido nenhuma atenção do Estado. Embora excluídos expressamente da regulação do contrato de trabalho estabelecida pela $\mathrm{CLT}^{50}$, o trabalho rural foi objeto do Decreto-Lei 7.038, de 10 de novembro de 1944, que dispunha sobre a sindicalização rural. Os efeitos da legislação no campo foram, de fato, diminutos, como reconheceu Oliveira Vianna (1987, p. 445), uma vez que o controle ostensivo dos proprietários e as dificuldades de difusão das idéias entre os trabalhadores impediram que um número significativo de sindicatos fosse formado e legalizado (MOREIRA, 1998). Até 1960, eram apenas 10 os sindicatos de trabalhadores rurais que haviam recebido autorização do Ministério do Trabalho, 8 dos quais criados na década de 1950 e que, ademais, estavam sujeitos à intensa pressão contrária ao seu funcionamento. Os empregadores, por sua vez, haviam criado até 1960 nada menos que 149 sindicatos patronais rurais (IBGE, 2003, p. 114).

Embora alvo de iniciativas legislativas e algumas ações estatais, a atenção conferida às relações de trabalho no campo e à sua proteção pela política populista foi mesmo secundária (FAUSTO, 2000b, p. 443). Em primeiro lugar, porque para o setor essa regulação não era estratégica como para os setores urbanos. Embora o pólo agroexportador ainda representasse parte significativa da elite e o governo populista tivesse de conquistar a sua lealdade, não foi apresentado um projeto distinto ou inovador para as atividades rurais, mantendo-se a administração de preços de gêneros agropecuários pela compra dos excedentes ou sua destruição. Continuava-se com a monocultura para exportação e, para a formação e manutenção de laços de lealdade com a elite rural, o governo manteve, como é fartamente conhecido, a administração dos preços agrícolas com a queima de safras. Nesse sentido, o projeto de desenvolvimento no país focava-se em bases industriais e não tinha como prioridade a reorganização ou racionalização do campo.

Em segundo lugar, porque a mobilização era incipiente. Como reconhece Fausto, no campo não surgiram “[...] movimentos de vulto, cujas características ultrapassassem os limites pré-políticos” (2000a, p. 21). De acordo com o mesmo autor, os movimentos sociais por excelência que emergiram no campo durante a República Velha foram aqueles marcados por forte conteúdo religioso, ainda que refletissem agudas carências sociais, como Canudos e Contestado. Os movimentos sociais que expressaram reivindicações sociais sem conteúdo religioso foram reduzidos, alimentados por colonos estrangeiros, e

\footnotetext{
${ }^{50} \mathrm{O}$ art. $7^{\circ}, b$, determina que os preceitos constantes do diploma legal não se aplicam ao trabalhador rural.
} 
ocorreram, majoritariamente, na produção cafeeira do interior paulista, alimentadas por colonos estrangeiros (2000b, p. 295).

As condições do campo, em especial em face da estrutura fundiária brasileira, altamente concentrada e extensiva, dificultaram a organização dos trabalhadores rurais, particularmente pela impossibilidade de tomada de consciência da comunhão de condições. Fazendas isoladas faziam com que trabalhadores estivessem dispersos e dificultavam os contatos; as idéias reformistas e revolucionárias não tinham como penetrar no mundo rural altamente controlado pela figura do fazendeiro que, ademais, controlava as instituições de poder local e, assim, podia afastar e reprimir, com o uso da lei, quaisquer células que julgasse subversivas.

Ainda assim, a ação coletiva no campo ganha vulto, na década de 1950, potencializada pelo mesmo crescimento da população urbana e da indústria que explicam os movimentos urbanos do período. Pode parecer, à primeira vista, paradoxal que uma causa externa ao campo seja a variável explicativa de um fenômeno rural. Contudo, o crescimento da população urbana e das forças industriais projetava-se também sobre o campo. Primeiramente, porque a demanda ampliava o mercado para gêneros agrícolas e pecuários e incentivava maiores índices de produtividade. Como a tecnologia no campo ainda era reduzida, e a produção extensiva, a terra torna-se um fator extremamente rentável e o custo das propriedades e arrendamentos eleva-se. As conseqüências são a expulsão do campo de um expressivo contingente populacional de pequenos proprietários e arrendatários, para dar lugar a uma concentração da propriedade agrícola, e o agravamento das condições de trabalho no campo. Chega-se a estabelecer a medieval figura consistente em obrigar os arrendatários a prestar um dia de trabalho gratuito, por semana, para o proprietário. Depois, porque o crescimento urbano aumentava a difusão de idéias que permitiam a tomada de consciência. Como muitos trabalhadores e arrendatários rurais foram expulsos para as cidades, tomavam contato com essas idéias e passavam a difundilas no campo (FAUSTO, 2000b, p. 444).

É nesse contexto que surgiram, em 1955, as Ligas Camponesas, lideradas por uma figura da classe média urbana, Francisco Julião, à margem dos sindicatos camponeses. As ligas, que se concentravam no Nordeste, agremiavam a população rural que possuía algum controle sobre a terra, principalmente na forma de arrendamentos, em torno da defesa contra a expulsão promovida pelos grandes proprietários e de melhores condições de trabalho. Julião procurou imprimir ao movimento uma organização centralizada, com sedes 
em centros urbanos, julgando essa solução oportuna para aproximar a população urbana dos problemas no campo e a população rural de idéias que fomentavam uma tomada de consciência (idem, p. 444).

Além das ligas, integrantes do Partido Comunista difundiram-se entre os assalariados agrícolas de São Paulo e Paraná. Ao contrário do movimento de Julião, que pretendia a expropriação de terras, os comunistas apresentavam uma proposta mais alinhada ao governo, defendendo a sindicalização rural e a extensão da legislação trabalhista no campo. O resultado desses movimentos, no intervalo democrático, seria justamente a concessão de direitos aos trabalhadores rurais, por meio do Estatuto do Trabalhador Rural, em 1963, que instituía a carteira de trabalho, regulava a duração da jornada, o salário mínimo e as férias entre os camponeses (idem, p. 444).

Reproduzia-se para o campo a mesma lógica de reconhecimento cívico por meio ocupacional que se estabelecera na era anterior para os trabalhadores urbanos. No mais, as dificuldades de fiscalização do trabalho rural permitiram a sistemática inobservância desses direitos e a contratação de lavradores em condições subumanas.

\subsection{4-1988: Consolidação e esgotamento do modelo}

Ao golpe de 1964 seguiu-se o desmonte do modelo de administração nacional populista que se instaurara com Vargas e que fora mantido, inclusive com a influência e participação desse, após a redemocratização. Fomentado, entre outras razões, pela crise econômica e pela incapacidade do governo em processar as demandas populares e das elites, julgava-se imperioso restaurar a ordem necessária para a produção nacional e para a atração de investimentos. A cúpula das forças militares, em conjunto com a classe dominante, julgava que o governo de Goulart, associado ao sistema sindical e aos partidos de esquerda, tornara-se potencialmente revolucionário (IANNI, 1968, p. 151).

Na visão do movimento militar de 1964, informada pela Doutrina da Segurança Nacional, era necessário reprimir os elementos populares que integravam as instâncias políticas e suas manifestações. Os sindicatos, considerados elementos fomentadores da subversão que se instalara, deviam ser controlados e sua ação diluída. Novamente impunha-se a racionalização das relações sociais e das forças produtivas como condição para o desenvolvimento nacional. 
O elemento populista, nesse sentido, devia ser eliminado, e substituído pelo pragmatismo racional, como bem sintetizou o Ministro Roberto Campos, em dois momentos citados por Ianni: “O atual governo não se propôs ser agradável com todos. Propôs-se, isto sim, cumprir o que as circunstâncias dele exigiam” (1968, p. 191). "Pois se os fins da sociedade podem estar envoltos em mística e magia os seus meios e métodos têm que ser racionais e eficazes” (idem, p. 194).

A eliminação do elemento populista, a despeito de significar um desprezo pela organização sindical, não modificou fundamentalmente a retórica da colaboração entre as classes. No pensamento autoritário de que o novo governo estava imbuído, assim como na retórica getulista, a ordem seria alcançada pela harmonia de interesses entre trabalhadores e empresários (idem, p. 193). Mas a preferência por tornar-se sócio menor do capital estrangeiro no processo de acumulação modificou a orientação do compromisso de interesses forjado no período. Ao abandonar um projeto de desenvolvimento autônomo, nacionalista portanto, e admitir a interdependência, o Estado deixou de promover a reprodução, pelos sindicatos, de interesses nacionalistas e críticas ao capital estrangeiro, como na Era Vargas. A “ideologia da modernização”, processo de adaptação das expectativas dos grupos sociais ao status quo toma o lugar que antes pertencera à “ideologia do desenvolvimento”, de acordo com Ianni (1968, p. 187-8). Destaca-se, então, o compromisso e orientação primordial do regime com a manutenção da ordem e da paz social (MARTINS, 1989), em detrimento da promoção do desenvolvimento.

O início do regime militar foi período de consecução das reformas estruturais pensadas no interior da agenda modernizadora do período 1945-1964, de acordo com a perspectiva conservadora e com a exclusão dos setores progressistas e populares (DRAIBE, 1994, p. 278). Assim como ocorrera com o Governo Provisório de Vargas em relação às demandas encaminhadas na República Velha, algumas pretensões das classes populares, dentre as quais os trabalhadores, foram contempladas pelo programa ditatorial, pródigo na produção legislativa. Assim como ocorrera no período autoritário anterior, a transformação dessas demandas em legislação e programas de política operou-se sem a participação dos atores que as haviam formulado. Pode-se apontar, a título de ilustração, a aprovação da Lei da Locação e do Estatuto da Terra, visando a mitigar, sem grande êxito, os problemas de habitação e da concentração fundiária. Além disso, estendeu-se a proteção 
social ao meio rural, com a criação em 1971 do FUNRURAL, para financiamento de aposentadorias e pensões de trabalhadores do campo.

Consolidou-se, no período, o padrão de intervenção social corporativo e conservador, com a fixação de estruturas e corpos funcionais burocráticos. O Estado manteve, ademais, com grande força retórica, a preocupação do período anterior com a modernização e racionalização da administração, que afetava a organização das relações de trabalho. Todas as iniciativas contribuíram para completar o padrão de intervenção social do Estado brasileiro e, mais especificamente, o aparato de regulação do trabalho, "sob as características autoritárias e tecnocráticas do regime” (idem, p. 276). Consagrou-se no período, ademais, um dos principais atributos que o padrão de intervenção social no país assumiu: o financiamento dos programas sociais por meio de fundos públicos (DRAIBE, 1994; CARDOSO JR; LACCOUD, 2005). Além do já mencionado FUNRURAL, destacam-se pela sua relação com o mundo do trabalho a criação dos Programas de Integração Social (PIS), de Formação do Patrimônio do Servidor Público (PASEP) e do Fundo de Garantia por Tempo de Serviço (FGTS), examinado adiante. Esses fundos interferem na organização do trabalho porque as contribuições sociais a eles destinadas, além de poupança compulsória dos trabalhadores, tornar-se-ão fonte de financiamento de programas de emprego e do sistema sindical.

Uma alteração merece, contudo, destaque. Sob o governo militar, operou-se uma cisão entre os sistemas de provisão social e de regulação do trabalho. No que diz respeito ao primeiro, a burocracia conseguiu vencer a oligarquia sindical e promover uma relativa universalização, além da superação da heterogeneidade dos benefícios sociais estabelecida em função das ocupações profissionais. O governo logrou, nesse sentido, uniformizar os serviços previdenciários dos trabalhadores da iniciativa privada por meio da Lei Orgânica da Previdência Social e a criação do Instituto Nacional de Previdência Social (INPS), em 1967 (SANTOS, 1979, p. 74). O processo de uniformização foi apenas limitado pela manutenção de estruturas segregadas de proteção social para os servidores públicos civis e militares, cujos privilégios foram conservados (DRAIBE, 1994). O INPS incorporou os vários IAPs, retirando a gestão da proteção social das burocracias sindicais e passando-a ao controle de uma nova autarquia criada pelo Estado. Retirava-se dos sindicatos, desse modo, o controle de benefícios que atuavam como incentivos que atraíam trabalhadores para os sindicatos. 
O padrão de organização e regulação do trabalho, por sua vez, permaneceu praticamente inalterado. Seu documento estruturante, a CLT, não contradizia os interesses dos militares e mostrava-se eficaz na gestão dos conflitos sociais, ao impor uma racionalidade material limitadora das pretensões de trabalhadores e seus sindicatos. Oferecia, ainda, a possibilidade para que a ditadura controlasse e interviesse nas atividades sindicais, destituindo lideranças consideradas subversivas (RODRIGUES, L. M., 1990, p. 67; COSTA, M. S., 2005, p. 116).

A despeito da manutenção do caráter geral do aparato de regulação jurídica das relações de trabalho instalado sob a presidência de Vargas, houve no período reformas legislativas e institucionais de grande impacto. O regime militar realizou diversas alterações na CLT, incidentes sobre a Justiça do Trabalho, a organização e administração dos sindicatos, a regulação das negociações coletivas que modificaram a extensão e a natureza da representação sindical. O título VI, referente às negociações coletivas, foi alterado integralmente pelo Decreto-lei $\mathrm{n}^{0}$ 229, de 28 de fevereiro de 1967. A mais importante reforma introduzida por esse decreto foi a revogação do antigo artigo 612 da CLT, que determinava que os termos dos contratos (atuais convenções e acordos) coletivos aplicavam-se aos associados dos sindicatos, de modo que apenas esses podiam usufruir dos benefícios pactuados. Ao revogar referido dispositivo, os não-filiados passaram a ter suas condições de trabalho também regidas pelos contratos coletivos de trabalho negociados pelo sindicato da categoria. Desse modo, o sindicato passou a representar todos aqueles que participavam da categoria perante o Estado, a Justiça do Trabalho e o sindicato patronal (econômico) em negociações e dissídios. Como decorrência, a reforma promovida estendia os benefícios conquistados pelo sindicato a toda a categoria, independentemente de associação, e removia um importante incentivo antes existente para a filiação. Outra reforma com semelhante efeito foi a revogação da exigência de associação formal ao sindicato para a promoção de reclamações trabalhistas perante a Justiça.

Conjugadas, as alterações desestimulam a filiação e modificam o significado da representação sindical, estendendo-a para além do grupo de trabalhadores com efetivos vínculos com o sindicato. O pertencimento à categoria torna-se o elemento suficiente para que os trabalhadores possam usufruir de todos os direitos que eram oferecidos, com exceção da eleição de lideranças sindicais, direito restrito aos associados sindicais. Por essa razão, a cobertura das negociações coletivas no Brasil torna-se, nesse período, 
praticamente absoluta, estendendo-se a toda a categoria profissional, mas deixa de possuir qualquer significado em termos de militância sindical.

No bojo do processo de modernização administrativa promovida pelos militares, processaram-se também algumas alterações na legislação trabalhista com o intuito de conferir maior eficiência administrativa à estrutura sindical e ao Ministério do Trabalho. Esse processo de racionalização atingiu tanto a organização dos sindicatos, quanto seus burocratas (MARTINS, 1989). Ademais, a consolidação de estruturas hierárquicas, com federações e confederações, entronizou um padrão de ação sindical burocratizado, pouco transparente e profundamente distante das bases. Os líderes sindicais que ocupam por longos períodos cargos na estrutura criam intensos vínculos com as administrações estaduais e federais e os representantes patronais com os quais devem dialogar mas, como sua ação tem pouca penetração no chão-de-fábrica, distanciam-se profundamente das bases.

O propósito do regime militar com essas reformas era claramente o de esvaziamento dos sindicatos. Pretendia-se anular vínculos com as bases - os trabalhadores da categoria -, construídos por meio da filiação, e reduzir ao máximo a militância e o envolvimento dos trabalhadores nas questões dos sindicatos, como instrumento de controle da agitação sindical e de garantia da ordem na produção. A medida comprometia a função de representação dos interesses dos trabalhadores, razão de ser dos sindicatos, transformando-os em órgãos com funcionamento autômato, independente da existência de membros que manifestem os reais interesses da categoria, apontando os caminhos a serem perseguidos pelo sindicato, e confiram suporte às decisões sindicais, legitimando-as perante a sociedade.

Há, no período, ademais, duas iniciativas legislativas que merecem atenção. A primeira é a criação do Fundo de Garantia do Tempo de Serviço (FGTS), pela Lei 5.107/1966 que, aliás, inscreve-se na marcha de formação de fundos de poupança compulsória. No caso do FGTS, essa poupança foi pensada como forma de compensação para os empregados demitidos, mas, em realidade, constituiu um fundo público para o financiamento de obras públicas de grande vulto em áreas consideradas prioritárias. Sua relevância para a regulação do trabalho no país justifica-se pela alteração que promoveu nas condições de execução do contrato de trabalho: o FGTS eliminou a estabilidade da relação de emprego adquirida após dez anos de vínculo. Até então a legislação trabalhista restringia a liberdade de demissão pelos empregadores, ao estipular a obrigatoriedade de 
pagamento de pesadas indenizações no caso de demissões de empregados com maior antiguidade. A garantia de estabilidade, ao reduzir a rotatividade da força de trabalho, permitia a convivência duradoura de grupos de trabalho e, conseqüentemente, fomentava a formação da identidade de classe e de um espírito de cooperação (COSTA, M. S., 2005, p. 116).

O FGTS era mecanismo útil ao empresariado e ao Estado por múltiplas razões. Primeiramente, reduzia os custos indenizatórios associados à demissão, potencializando a circulação e substitutibilidade da mão-de-obra. Em decorrência, permitia às empresas utilizar o exército de reserva como fator de redução dos salários. Desse modo, reduzia as pressões por reajustes salariais, integrando-se aos objetivos da política econômica do regime de empregar o controle oficial dos salários - e o arrocho - como forma de controlar as pressões inflacionárias. Por fim, o FGTS agia como fator de controle disciplinar e de dissuasão do conflito no interior da empresa, ao aumentar o risco de demissão.

O emprego do FGTS como instrumento de controle inflacionário revela, aliás, uma fundamental característica da organização e regulação do trabalho, promovidas pelo regime militar e os sindicatos. No período, a política de regulação do trabalho subordinouse diretamente à política econômica desenvolvida pelo governo e foi empregada como instrumento de controle inflacionário. Até então, salários, reajustes e gratificações não eram fixados por lei e permaneciam no já limitado espaço negocial disponível aos atores do mundo do trabalho. Entretanto, nesse período os salários e seus reajustes passaram a ser definidos pelo Estado, sem a participação dos trabalhadores. O controle salarial assumia dupla função: controlar a inflação, ao limitar os reajustes salariais aos níveis oficiais, muito abaixo dos reajustes reais de preços, e disponibilizar força de trabalho no mercado ao menor custo possível e controlar a inflação.

Subtraia-se, assim, mais uma matéria do âmbito de negociação sindical. Essa limitação foi convertida em proibição legal com o advento do já mencionado Decreto-lei $n^{\circ}$ 229 que, ao alterar o título VI da CLT, incluiu o art. 623, dispondo ser nula a convenção ou acordo que contrarie proibição ou norma disciplinadora da política salarial vigente. Sendo fixados pelo Estado os salários, os sindicatos não podiam negociar salários ou encaminhar demandas, a não ser que referendassem a política salarial do governo.

O segundo diploma legal é a Lei 4.330/1964, que regulamentava a greve, mais uma vez no esforço de racionalizar o conflito industrial e garantir a ordem. A lei foi criada no início do regime militar, diante do diagnóstico, expresso no Plano de Ação Estratégica 
Governamental (PAEG), de que era necessário controlar as constantes greves que desestimulavam a produção e os investimentos (MARTINS, 1989, p. 117). Como a Constituição de 1946, ainda em vigor, garantia o direito de greve, assim como faria a Constituição de 1967 em seu artigo 158, buscou-se restringir seu exercício por meio da criação de um procedimento legal burocrático bastante arrastado. A lei trazia uma plêiade de disposições que restringiam a possibilidade de uma categoria suspender os serviços, estabelecendo requisitos com os quais o patronato obtinha tempo para reagir. Mais uma vez, o sindicato era conclamado a agir como conciliador (MARTINS, 1989, p. 123), sendo compelido a negociar com o Estado e os empregadores antes de suspender a produção. Frustradas as tentativas de conciliação, os sindicatos deviam ainda propor um dissídio coletivo perante a Justiça do Trabalho, que deveria intentar novo acerto ${ }^{51}$. Somente após a frustração da conciliação e no caso de não cumprimento da decisão proferida em dissídio coletivo é que se autorizava, presentes os demais requisitos legais ${ }^{52}$, o abandono pacífico dos postos de trabalho. Proibiam-se, também, greves por motivos políticos ou sociais, autorizando-se apenas as reivindicações de caráter econômico, assim entendidas aquelas de caráter salarial (art. $2^{\circ}$ ), no estrito interesse da categoria (art. 22) (idem, p. 119). Impediase, portanto, qualquer manifestação de contrariedade ao regime ou de solidariedade entre categorias, mutilando o movimento dos trabalhadores e confinando-o aos limites da identidade de ocupação, estabelecida por uma definição legal.

O programa de reformas legislativas e institucionais no aparato de regulação das relações de trabalho promovido pelos governos militares refletia uma nova posição do Estado em relação às funções que os sindicatos deveriam assumir. Como visto, o interesse de manutenção da ordem se sobrepunha, nesse período, ao desenvolvimento das forças produtivas nacionais. Nesse sentido, os sindicatos perdem a função que desempenharam na Era Vargas, de colaboração nos esforços de desenvolvimento, e conseqüentemente o prestígio e os espaços políticos privilegiados de que dispunham no interior da máquina estatal.

A nova prioridade da organização e regulação das relações de trabalho era a anulação completa da ação coletiva, que se multiplicara nos primeiros anos da década de

\footnotetext{
${ }^{51}$ Desde então, a negociação coletiva tornou-se obrigatória aos sindicatos, que podem ser convocados compulsoriamente no caso de recusa. Se ainda assim não se concretizar a negociação, instaura-se dissídio coletivo (art. 616 da CLT, inserido pelo Decreto-lei no. 229, de 28 de fevereiro de 1967). Instaurado o dissídio, a Justiça pode requisitar uso da força para manter a ordem (art. 682 da CLT).

${ }^{52}$ Os requisitos estabelecidos pelo art. $6^{\circ}$ da lei são muitos e encontram-se sintetizados em MARTINS, 1989, p. 118.
} 
1960, e a restituição da ordem ao mundo da produção. O novo regime não julgava necessário atrair a lealdade do operariado, mas apenas controlar os conflitos e, dessa forma, preferia inverter o vetor de controle dos sindicatos que se havia estabelecido pelo modelo corporativo: ao invés de aproximar os sindicatos do Estado, é este que se lança sobre aqueles, ocupando-os e utilizando brechas legais oferecidas pela CLT para intervir em seus rumos, impedir manifestações e garantir a eleição de lideranças comprometidas com a ordem. Ademais, o regime empregou as já mencionadas reformas legislativas e institucionais para esvaziar sindicatos e controlar militâncias. Os sindicatos, por sua vez, impedidos de apresentar demandas substantivas e defender os legítimos interesses dos trabalhadores, consolidaram-se como entidades assistenciais, especializadas na prestação de serviços de assistência médica, social e jurídica, bem como na proporção de espaços recreacionais, como clubes e colônias de férias, a seus filiados (CARDOSO, A. M., 2001).

A representação pela via corporativa foi anulada, com o único prejuízo para os trabalhadores. Fecharam-se os tradicionais canais de interlocução que, embora limitados, formaram-se no interior da estrutura burocrática para os sindicatos de empregados, e o Estado deixou de incorporar sindicatos e atrair suas lideranças para o interior de sua burocracia. O trabalho organizado, por mais dócil e obediente que houvesse se tornado, não tinha lugar reconhecido no projeto tecnocrático de desenvolvimento nacional, embora tenham sido as mãos que efetivamente fizeram o milagre econômico brasileiro e aquelas que mais se sacrificavam pela estabilização econômica nacional, tendo de aceitar duras políticas de controle salarial, baseadas em índices de inflação manipulados. O fato é bem ilustrado no editorial que Paulo Vidal ${ }^{53}$, presidente do Sindicato dos Metalúrgicos de São Bernardo, disposto a colaborar com o regime, redige no jornal do sindicato, dirigindo-o ao recém-empossado Geisel:

\footnotetext{
O sindicalismo sequer figurou nos planos, o que deixa prever a sua continua marginalização no atual processo. Não queremos nos contrapor ao Regime, Sistema Econômico ou às autoridades. O que queremos é ver reconhecido o direito de podermos participar no processo de desenvolvimento que a nação experimenta e do qual somos partes. [...] (apud SADER, 1988, p. 182)
}

A ausência de intermediação de interesses do trabalho nos governos militares foi compensada, no período, pelo recrudescimento da resposta repressiva, com a proibição de

53 Antecessor de Luis Inácio da Silva, eleito em 1974, Vidal assumiu a presidência do Sindicato dos Metalúrgicos em 1969, opondo-se à esquerda e procurando controlar a militância exaltada pela greve de Osasco do ano anterior. 
greves, a prisão de lideranças sindicais e a intervenção violenta em sedes. Na década de 1970, no auge da brutalidade da repressão militar, os esforços de desarticulação de todos os movimentos populares considerados subversivos passa a contar com um novo instrumento jurídico: a Lei de Segurança Nacional criminaliza a ação popular, considerando-a atentatória aos interesses nacionais (SADER, 1988)

O esvaziamento dos canais de interlocução de interesses próprios do aparato corporativo não representou, porém, significativos prejuízos à classe patronal. Rompendo com o padrão de cooptação das lideranças representativas do trabalho, próprio do período nacional populista, o regime militar restringiu os privilégios das oligarquias sindicais e passou a relacionar-se diretamente com a sociedade, por meio da cooptação de indivíduos e canalização de interesses privados. Em oposição aos canais corporativos de representação, passa a haver uma negociação direta e individual dos grupos interessados com o Estado (DRAIBE, 1994, p. 291), formando o que Fernando Henrique Cardoso denominou de anéis burocráticos (1975, p. 182). Por meio desses, estabeleciam-se laços entre a alta administração dos grandes conglomerados empresariais e a burocracia estatal, em especial aquela na administração das empresas públicas.

Por óbvio que essa estrutura, que fundia interesses públicos e privados, era mais propícia à promoção de interesses do capital, com maiores facilidades de transitar junto à administração. A estrutura administrativa estatal, em que proliferavam empresas públicas, órgãos de planejamento regional e autarquias, apresentava espaços para a representação ou cooptação apenas dos interesses empresariais (DRAIBE, 1994, p. 184). O papel que os empresários da construção e prestação de serviços de saúde e educação desempenharam na formulação e execução de obras e políticas sociais é revelador da manutenção de formas clientelísticas de alocação de recursos, agora como resultado da formação desses anéis burocráticos.

Se por um lado o projeto militar anulou a participação sindical e reprimiu duramente suas ações, por outro, a negligência e a manutenção de uma estrutura de representação arcaica, conjugadas com a política econômica praticada na década de 1970 criaram as condições para o ressurgimento da ação coletiva dos trabalhadores, na forma do novo sindicalismo. Considerando o sufocamento do potencial de ação do sindicato oficial e a regulação limitadora das greves, uma nova ação coletiva começa a surgir, impulsionada pelas próprias bases operárias no interior das empresas e distante, portanto, dos sindicatos integrantes da estrutura oficial de representação (MARONI, 1982; COSTA, M. S., 2005, p. 
117-8). Como toda manifestação dirigida à estrutura de representação oficial, cujo papel tornara-se o de conciliador entre trabalhadores e capital, tendia a se atrofiar, transformando-se em um litígio judicial, a ação era promovida quase sempre à margem dessa estrutura (MARTINS, 1989, p. 128-30). Os esforços mobilizatórios envolviam as oposições sindicais, que buscavam uma nova forma de ação sindical.

Os militantes que formavam a base desses movimentos também eram distintos, em razão de uma mudança no perfil do operariado nos grandes centros industriais do Sudeste. A concentração do desenvolvimento econômico nacional no Sul e Sudeste acentua, a partir da década de 1960, os fluxos migratórios provenientes de regiões menos dinâmicas, especialmente do Nordeste. A força de trabalho das grandes indústrias passa, portanto, por uma alteração, elevando-se o número de migrantes. Normalmente proveniente de regiões muito pobres e com fortes tradições, o trabalhador perde suas referências fundamentais de sentido nos grandes centros urbanos e sente-se deslocado diante das práticas e valores cosmopolitas (SADER, 1988). As promessas e os estímulos urbanos são muitos, mas o trabalho industrial garante muito pouco das expectativas e sonhos. Essa situação tende a agravar a situação de desalento diante da super-exploração e das péssimas condições de vida à que é condenado nas cidades.

As formas de ação também eram distintas. Como a repressão militar impedia qualquer manifestação pública do operariado, os trabalhadores passaram a organizar-se e agir no interior das fábricas. Os instrumentos de protesto incluíam formas de controle da produção, como operações tartaruga e metas restritas de trabalho, e até a interrupção do trabalho sem abandono dos postos de trabalho (MARONI, 1982; SADER, 1988). Outra inovação foi a constituição de comissões de fábrica, órgãos de representação interna e encaminhamento de demandas ao patronato, que visavam a driblar a ausência dos sindicatos no interior das empresas. Ao desenvolver um relacionamento íntimo e permanente com os colegas de trabalho e basear sua atuação diretamente nas demandas e necessidades vocalizadas no chão-de-fábrica, as comissões constituíram uma forma de representação alternativa dos trabalhadores. Contribuíram, também, para as lutas pela democratização do espaço produtivo, exigindo poderes de consulta e deliberação sobre práticas de trabalho (RODRIGUES, I. J, 1990) ${ }^{54}$.

Paulatinamente, os trabalhadores voltam a manifestar-se publicamente. As lideranças do novo sindicalismo, dentre as quais Luís Inácio da Silva tornar-se-ia o mais

\footnotetext{
${ }^{54} \mathrm{~A}$ obra de Jácome Rodrigues aborda com detalhes o histórico, desenvolvimento e principais características das comissões de fábrica, destacando-as como uma alternativa às organizações tradicionais dos trabalhadores.
} 
ilustre, revelavam um elevado poder de mobilização, produto do intenso trabalho realizado junto às bases, e uma postura mais combativa, ainda que profundamente pragmática, disposta a concessões. O pragmatismo seria, aliás, a característica mais duradoura desse novo sindicalismo, persistindo após a redemocratização.

Sader (1988, pp. 38-44) julga que os novos movimentos que eclodiram, sobretudo em São Paulo, no final da década de 1970, não tinham suas origens associadas a condições decorrentes do sistema social, isto é, a características estruturais do padrão de acumulação e suas dimensões social e geográfica. Nenhuma dessas condições objetivas, argumenta, seria capaz de explicar a emergência e a singularidade desses movimentos, o que só seria possível com a reconstrução da experiência subjetiva dos atores. Ainda que a singularidade do movimento resida na experiência das condições dadas pelos seus membros, não há como negar que as condições objetivas influam nessas experiências.

A política de arrocho salarial, o desenvolvimento econômico concentrado no Sul e Sudeste e a oligopolização da indústria foram todos fatores que influíram para a formação do novo sindicalismo. A perda do poder de compra pelos trabalhadores, motivada pela sustentada política de arrocho salarial e pela emissão inflacionária, fez eclodir um forte sentimento de insatisfação com o regime. O esgotamento do milagre econômico e a perda de valor dos salários, afetaram os assalariados e suas famílias e deterioraram as condições de vida da população. O aumento do custo de vida e a deterioração do salário real foram causas de diversas ações dos trabalhadores em busca de reposição salarial, às quais se uniram reivindicações de donas-de-casa em associações de bairro, movimentos de custo de vida e comunidades eclesiais de base.

A concentração do desenvolvimento econômico nos grandes centros urbanos do Sul e Sudeste também favoreceu a organização dos trabalhadores. A concentração espacial de um grande número de trabalhadores facilitava a formação de uma identidade comum e a mobilização coletiva (STEPAN, 1985). Considerando que alguns setores eram conformados por poucas indústrias, com plantas de amplas dimensões e elevado número de funcionários nas regiões metropolitanas, a formação de laços oriundos da experiência comum das condições de trabalho e dos salários era inevitável. Foi nas empresas pertencentes aos setores mais dinâmicos e modernos da indústria que emerge uma nova forma de ação sindical, mais combativa e próxima dos trabalhadores no chão-de-fábrica.

Ademais, o dinamismo das indústrias, juntamente com a estrutura oligopolizada do capital, ampliava os custos econômicos da aplicação de práticas restritivas da produção 
pelos trabalhadores. Por essa razão, os sindicatos tinham, em suas mãos, o poder de paralisação de setores econômicos dinâmicos, dos quais dependia a economia. O impacto era, portanto, elevado e ambos os lados, consciente do poder aumentado que a situação conferia aos trabalhadores, adaptou suas ações. Por um lado, o novo sindicalismo soube empregar a ameaça de sanção nas negociações que estabeleceu com o patronato, por outro lado este se mostrou mais disposto a dialogar. Na medida em que os recursos à intervenção estatal nos conflitos e a seus mecanismos de controle sindical haviam se tornado ineficientes para evitar as greves, muitos empresários preferiam negociar (OLIVEIRA, M. A., 2003, p. 273). As elevadas taxas de lucro e a ausência de concorrência, interna ou externa, permitiam à gerência das empresas envolvidas em disputas com os sindicatos acatar demandas e conceder aumentos, buscando atrair a lealdade dos trabalhadores e evitar a interrupção da produção. Em certa medida, os empresários desses setores conferiram voz aos trabalhadores, em troca da lealdade a metas de produtividade (HIRSCHMAN, 1973) ${ }^{55}$.

Contudo, a política salarial implementada com finalidade de controle inflacionário regulava legalmente os salários e, desse modo, limitava a negociação entre as partes e a capacidade dos empresários de atender às demandas formuladas pelos trabalhadores. A expressão das demandas era tolerada por indústrias, muitas vezes, para que servissem como uma demonstração de sua impotência para administrar os conflitos e implementar formas mais modernas de gestão do trabalho em razão da forte intervenção estatal (STEPAN, 1985).

As primeiras manifestações públicas dos trabalhadores no início da distensão política, ainda na década de 1970, constituíam greves econômicas, em que se buscava superar a super-exploração do trabalho e garantir aumentos salariais reais (ANTUNES, 1988). Ao final da década de 1970, entretanto, as demandas passaram a incluir uma atenuação dos controles exercidos sobre o trabalho, mas também a ampliação dos direitos de cidadania, com incremento da participação na política (MARONI, 1982). Em realidade, as demandas pela atenuação dos controles sobre o trabalho e por reajustes e benefícios que representassem uma parcela mais justa da riqueza social reuniam, a um só tempo, dimensões políticas e econômicas. Eram produto de condições de trabalho que lhes eram

\footnotetext{
${ }^{55}$ Os conceitos de Hirschman não compõem o marco analítico desta pesquisa, mas são em tudo compatíveis com o institucionalismo histórico e as teorias das oportunidades políticas que o integram. Para essas vertentes teóricas, a ação também é o produto de uma escolha entre rumos possíveis, a partir da consideração das oportunidades e recursos disponíveis, além dos constrangimentos.
} 
impostas pelo patronato, mas também refletiam as políticas e diretrizes do regime. Criticar os baixos salários, defasados em relação à inflação, representava, por exemplo, questionar a política salarial, um dos pilares da política econômica praticada pelos militares e sua capacidade de administrar a inflação sem impor condições que ameaçassem a reprodução da força de trabalho (OLIVEIRA, M. A., 2003, p. 273). As condições rígidas de trabalho e a super-exploração à qual eram submetidos os trabalhadores, por sua vez, eram um reflexo da debilidade da estrutura sindical, sua ausência do interior das empresas e sua incapacidade de resistir à imposição de controles, bem como negociar condições mais benéficas. Os controles rígidos sobre os sindicatos praticados pelo regime impediam que as ações, no interior do sistema oficial de representação, assumissem padrões diferentes. Por essa razão, lutar contra controles e condições precárias de emprego ganhava, também, uma conotação de demanda dirigida ao governo pelo resgate das liberdades elementares e das prerrogativas de ação sindical (idem, p. 275).

O ressurgimento da ação coletiva ao final da década de 1970 e o endividamento crescente aceleraram o esgotamento da capacidade de gestão social e econômica do regime militar. Baseado no princípio contributivo e vinculado à inserção no mercado formal de trabalho, o modelo de intervenção social dependia de um amplo assalariamento como base de financiamento. A redução drástica da quantidade de trabalho necessário na produção, compensada pela intensificação do capital fixo, comprometia as condições de disponibilidade e a capacidade de acessar recursos privados para financiar a ação social governamental. O próprio modelo de modernização, ao qual a intervenção social era instrumental, entrava em colapso com a redução da capacidade de investimento interno e o movimento generalizado de abertura de mercados.

Ademais, como produto autoritário completado pelos militares, os modelos de intervenção social no geral, e de regulação do trabalho em particular, passaram a ser questionados pelo conjunto de forças que pressionavam pela democratização. Draibe aponta, nesse sentido, que o modelo teve de enfrentar, desde o final da década de 1970, um forte questionamento de seus alicerces pelas oposições políticas e movimentos populares, que cobravam uma reestruturação do sistema de proteção social com a finalidade de superar o perfil excludente e autoritário que o tornara impermeável às demandas e pressões sociais (1994, p. 304). A emergência de novos movimentos sociais e, em especial do novo sindicalismo, criava grandes expectativas de reforma do aparato de regulação do trabalho e de restauração da autonomia para a organização e mobilização dos trabalhadores. Essas 
expectativas, porém, não se concretizaram. A incorporação de alguns setores desses movimentos ao Estado e as transformações na organização da produção no país limitariam a capacidade de transformação de expectativas e reivindicações em reformas substantivas no modelo de regulação jurídica do trabalho, em prejuízo, especialmente, dos trabalhadores.

\subsection{De 1988 aos dias de hoje: permanência do modelo e precarização das relações de trabalho}

Ao longo do período analisado, a intervenção estatal na questão social, notadamente nas relações de trabalho e na proteção contra os seus riscos, parece inscreverse na trajetória de crescente racionalização burocrática das relações estabelecidas entre os atores coletivos do mundo do trabalho, o capital e o Estado, por meio da gestão dos conflitos pela administração pública e subordinação da ação sindical à lógica racional da acumulação (MARTINS, 1989). A regulação jurídica do trabalho, em conjunto com o aparato de intervenção social, enquanto mantidas as condições de fundo socioeconômico que a alimentavam, logrou racionalizar o conflito industrial e reduzir o número de interrupções do processo produtivo, bem como as erupções violentas do operariado, por meio da criação de uma forma administrativa legal de processamento e neutralização dos conflitos. Em um círculo virtuoso de crescimento, o modelo logrou reproduzir-se porque, por um lado, a provisão de serviços sociais reduziu progressivamente os riscos e, por outro, o crescimento econômico manteve a demanda por trabalho e, conseqüentemente, uma base tributária de sustentação igualmente crescente, reduzindo a pressão sobre os programas, em especial aqueles destinados às parcelas da população desprovidas de emprego.

O cenário socioeconômico que alimentava esse ciclo transforma-se, entretanto, a partir do final da década de 1970 e erode as condições de sustentação do modelo. Simultaneamente, a redemocratização brasileira e a discussão em torno de uma nova Constituição abrem espaços para novos caminhos de intervenção social. Sendo o movimento impulsionado também pela ação de setores da classe trabalhadora, surgem expectativas de transformações que garantissem maior autonomia à ação sindical, universalização dos benefícios sociais e ampliação da participação na gestão dos rumos dos programas de proteção social. 
Embora algumas alterações tenham se processado no novo texto constitucional, o mesmo não refundou o sistema brasileiro de intervenção social (CARDOSO JR; JACCOUD, 2005, p. 183) e tampouco o aparato de regulação das relações de trabalho. Embora se pudessem esperar alterações sensíveis pela participação do novo sindicalismo, promotor de uma nova forma de ação coletiva, na arena política, esse não se mostrou menos inflexível em sua defesa da estrutura atual, à qual foi incorporado e cuja lógica passou a reproduzir. Venceram, então, as forças que desejavam a manutenção do padrão corporativista como modo predominante de organização das relações de trabalho e de reconhecimento da ação coletiva dos trabalhadores.

Por certo que houve alterações pontuais, mais tímidas do que prometia a forte organização dos trabalhadores na década de 1980. Finalmente foi assegurada a isonomia entre trabalhadores urbanos e rurais ao estenderem-se para os segundos os direitos há muito garantidos para os primeiros. A regulação expandiu-se, ainda, para proteger o trabalho doméstico e, sempre preservando o status diferenciado dos funcionários públicos, para garantir a esses o direito de associação e, embora de modo abstrato ${ }^{56}$, o de greve, revogando a antiga proibição da $\mathrm{CLT}^{57}$.

No que tange à constituição e organização dos sindicatos, as inovações da Constituição de 1988 também foram tímidas. A Carta, é verdade, proclama a autonomia formal das agremiações, ao vedar a interferência na organização sindical em seu artigo $8^{\circ}$, I. Entretanto, essa autonomia, se a situação permite empregar de fato esse termo, é muito mitigada pela manutenção das características próprias do sindicato oficial. O corpo de dispositivos constitucionais relativos aos sindicatos representa um paradoxo insolúvel. Ele proíbe a exigência de autorização estatal para a fundação do sindicato, mas mantém a obrigatoriedade do registro no órgão competente, a unicidade sindical (art. $8^{\circ}$, II) e a contribuição sindical obrigatória (art. 8, IV). O registro tornou-se, em um regime democrático, um ato mecânico da administração, que não exige grande consideração. Ainda assim, a exigência do registro mantém a dependência e o atrelamento dos sindicatos à burocracia estatal, da qual depende para existir e agir, direito que é limitado a uma única organização sindical por categoria em uma dada base territorial, não importando sua

\footnotetext{
${ }^{56}$ Diz-se de modo abstrato porque o dispositivo constitucional delega à lei a função de disciplinar as condições em que se pode realizar a suspensão das atividades produtivas e os padrões mínimos de funcionamento dos serviços públicos nessas situações. Desse modo, o Supremo Tribunal Federal interpretou o texto assumindo que as obrigações dos servidores públicos grevistas são as mesmas dos funcionários do setor privado, exigindo a manutenção dos serviços essenciais.

57 A CLT, em seu art. 566, proibia a sindicalização de servidores públicos, excetuando os funcionários de sociedades de economia mista, fundações constituídas pelo Estado e caixas econômicas (bancos públicos).
} 
representatividade real. Ao Estado ainda cabe, portanto, decidir qual organização deverá representar sua categoria e conferir-lhe status público, interferência nada trivial.

A Constituição também assegura o direito à greve (art. $9^{\circ}$ ), ampliado em relação ao marco legal anterior que, como visto, praticamente inviabilizava a interrupção legal da produção, introduzindo uma série de condições. Contudo, foram mantidas a distinção entre greves legais e ilegais, a responsabilidade de sindicatos e seus membros por abusos (art. $9^{\circ}, \S 2^{\circ}$ ) e a obrigatoriedade de arbitragem judicial para os conflitos trabalhistas (art. 114). A lei reguladora da greve (7.783/1989), ao tratar desse último dispositivo, manteve a obrigatoriedade de tentativa de acordo judicial prévio à interrupção do trabalho, sob pena de multa. A ação sindical em perseguição a demandas e interesses de seus representados continua, pois, sujeita ao controle judicial.

Mais notável foi o reconhecimento das centrais sindicais, que até 2007 permaneceram à margem do aparato de organização do trabalho, embora tenham se mostrado os mais ativos atores sindicais nas últimas décadas. Todavia, esse reconhecimento deu-se por meio da incorporação das centrais ao sistema oficial de representação, como beneficiárias de parcela das contribuições sindicais compulsórias.

Contudo, a vetusta CLT permanece em vigor, buscando inutilmente regular por meio de regras imutáveis gerais e homogêneas a enorme diversidade de formas de disposição da força de trabalho e relações estabelecidas entre empregados e empregadores, em um contexto produtivo flexível e dinâmico. O cenário econômico de reestruturação produtiva, abertura do mercado nacional e aumentada competição internacional, assim como a redução da quantidade de trabalho socialmente necessário, de um lado, e as dificuldades políticas de se conduzir uma reforma sistemática e abrangente, de outro, conduziram os governos recentes a produzir uma legislação específica, visando a relativizar a inflexibilidade da CLT e compensar a falta de espaço de negociação. Os interesses em torno da modernização do aparato de resolução de conflitos trabalhistas lograram eliminar a figura dos juízes classistas, representantes sindicais que integravam a Justiça do Trabalho, e criar as comissões de conciliação prévia (art. 625-A da CLT) como possível alternativa à solução das causas pela Justiça especializada. Foram, ainda, regulamentados novos regimes de trabalho. A Medida Provisória 2.164-41 de 2001 acrescentou a modalidade do trabalho em regime parcial, assim definido aquele cuja duração não excede 25 horas semanais (art. 58-A da CLT). A Medida, ainda, introduziu a possibilidade de suspensão temporária do contrato de trabalho para requalificação 
profissional, por dois a cinco meses, como forma de prevenir demissões em massa em conjunturas de baixa demanda. A lei 9.601/1998, por sua vez, introduziu a modalidade do trabalho por tempo determinado, para a ampliação dos postos de trabalho, dependente de acordo entre sindicatos e empresas que deve ser formalizado em acordos ou convenções coletivas de trabalho. O diploma também disciplinou a figura do banco de horas, importante para adaptar o contrato de trabalho a flutuações sazonais de demanda, permitindo a compensação de horas trabalhadas em excesso em momentos de alta demanda, pela redução da jornada de trabalho. Essas alterações, ainda que pontuais, demonstram que a os governos recentes têm cedido às demandas por maior flexibilidade provenientes do empresariado.

Resta evidente que os pilares do modelo corporativo de representação profissional permaneceram praticamente intocados, mantendo-se a estrutura vertical, a unicidade sindical, o imposto sindical e a supervisão do Ministério do Trabalho que mantém a heteronomia dos sindicatos. Mas como explicar a entronização do modelo, a incorporação de lideranças ligadas ao novo sindicalismo que buscavam vias mais autônomas de ação e, no geral, a manutenção do modelo em condições democráticas, mesmo após uma completa transformação do cenário social, político e econômico que lhe deu sustentação e até mesmo do projeto nacional que o ensejou?

Os motivos da entronização do modelo parecem ser a autonomização de seu funcionamento e a formação de clientelas fiéis. O amplo apoio ao modelo oficial de organização e regulação do trabalho pode ser explicado pela formação de um grupo de apoio formado por beneficiários, empregados públicos e os dependentes de ambos, além daqueles que esperam ser, no futuro, incluídos. Ademais, seu suporte popular não é apenas motivado por interesses próprios, já que sua legitimidade deriva também de seu reconhecimento como uma fonte de estabilidade social e garantia dos direitos básicos de cidadania que logrou enfrentar as mais graves crises socioeconômicas do século XX (PIERSON, 2001, p. 412-3). Com efeito, o modelo corporativo foi responsável pela geração de muitos benefícios e empregos ao longo de seus organismos: na estrutura da Justiça do Trabalho, que demanda ademais funcionários para o Ministério Público do Trabalho e advogados; no interior do Ministério do Trabalho e nos sindicatos, federações e confederações. Há, na estrutura, espaço para indivíduos de todos os níveis de qualificação e origem social (RODRIGUES, L. M., 1990, p. 65). 
Além de amplo, o apoio aos programas sociais é intenso, porque enquanto o interesse das clientelas que lutam pela manutenção do modelo é concentrado, os seus opositores possuem propostas e interesses múltiplos e difusos (PIERSON, 2001, p. 413). No caso da organização do trabalho, prefere-se manter a unicidade sindical, a contribuição oficial e a estrutura vinculada do que correr os riscos de ver o poder dos sindicatos pulverizado e fragmentação ainda maior dos trabalhadores. Os interesses envolvidos em sua manutenção, portanto, são mais fortes e amplos.

O interesse na manutenção da estrutura sindical, ou, ao menos, a oposição a reformas importantes, extravasa o corpo de funcionários envolvidos no sistema de regulação do trabalho. A clientela criada por esse sistema inclui ainda os trabalhadores, muitos dos quais se beneficiam com os serviços assistenciais prestados pelos seus sindicatos. Ao longo das décadas, a impossibilidade de uma ação mais combativa e da formulação de demandas substantivas de conteúdo político ou econômico conduziu a uma acomodação dos trabalhadores a um padrão de sindicalismo fortemente assistencialista. Consagrou-se no imaginário popular uma visão dos sindicatos como entidades não apenas altamente burocratizadas, mas também essencialmente prestadoras de serviços de interesse de seus representados. A qualidade e prestígio de um sindicato passaram a ser auferidos com referência à eficiência, qualidade e variedade dos serviços oferecidos à sua base. Desse modo, o padrão de sindicalismo efetivamente praticado determinou as expectativas futuras a respeito da atuação dessas organizações e passou a orientar os valores dos atores, que não conseguem imaginar um padrão diverso.

Algumas evidências dessa acomodação e da consagração dos sindicatos como entidades assistencialistas podem ser encontradas em uma pesquisa que o IBGE realizou em abril de 1996 como suplemento à sua Pesquisa Mensal de Emprego, que abrange as seis maiores áreas metropolitanas do país ${ }^{58}$, representando, naquele então, cerca de $25 \%$ da população nacional. O suplemento versava sobre associativismo e representação de interesses e é a mais recente fonte de dados nacionais a respeito da opinião da população nacional com relação a sindicatos e outras entidades de representação. Os dados coletados permitem verificar que os sindicatos gozam de um significativo prestígio, especialmente quando comparados a outras entidades públicas do governo ou da sociedade civil. Ao serem indagados a respeito das entidades que melhor defendem seus interesses, $23 \%$ dos respondentes que apontaram ao menos uma entidade mencionaram os sindicatos, que

\footnotetext{
${ }^{58}$ São elas São Paulo, Rio de Janeiro, Belo Horizonte, Salvador, Porto Alegre e Recife.
} 
foram considerados a segunda entidade que melhor representa os interesses, atrás apenas das igrejas e cultos religiosos, apontados por $29 \%$ dos respondentes como entidade que melhor defende seus interesses (Tabela 2).

Tabela 2: Entidades que melhor defendem os interesses da população

\begin{tabular}{|l|r|r|}
\hline \multicolumn{1}{|c|}{ Entidades } & $\begin{array}{c}\text { Total de } \\
\text { respondentes }\end{array}$ & \multicolumn{1}{c|}{ \% } \\
\hline Apontaram alguma entidade (1) & $\mathbf{8 . 6 5 1 . 4 8 7}$ & $\mathbf{1 0 0}$ \\
\hline Políticos & 1.175 .969 & 14 \\
\hline Presidente da República & 1.180 .614 & 14 \\
\hline Juizes & 969.280 & 11 \\
\hline Sindicatos & $\mathbf{2 . 0 2 4 . 3 1 6}$ & $\mathbf{2 3}$ \\
\hline Associações profissionais & 1.004 .235 & 12 \\
\hline Associações de bairro & 1.445 .634 & 17 \\
\hline Igrejas ou cultos religiosos & 2.466 .817 & 29 \\
\hline
\end{tabular}

Fonte: elaboração a partir de IBGE - Pesquisa Mensal de Emprego - Tema Representação de Interesses e Intermediação Política (IBGE, 1996).

(1) O total não é a soma das parcelas por tratar-se de quesito de múltipla marcação.

Além disso, a consagração dos sindicatos como entidades prestadoras de serviços é claramente demonstrada quando se verifica as razões da filiação. A pesquisa do IBGE demonstra que os principais motivos de filiação são a busca de serviços de assistência jurídica (33,13\% dos respondentes), assistência médica (26,66\%) e equipamentos para a realização de atividades culturais, esportivas ou recreativas (11,25\%), sendo que apenas 9,42\% dos entrevistados afirmaram haver se associado ao sindicato para realizar alguma atividade política (Tabela 3).

Tabela 3: Motivo da filiação sindical

\begin{tabular}{|l|r|r|}
\hline \multicolumn{1}{|c|}{ Motivo } & $\begin{array}{c}\text { Total de } \\
\text { respondentes }\end{array}$ & \multicolumn{1}{c|}{ \% } \\
\hline Total (1) & $\mathbf{3 . 2 7 4 . 2 7 4}$ & $\mathbf{1 0 0 , 0 0}$ \\
\hline Assistência jurídica & 1.084 .895 & 33,13 \\
\hline Assistência médica & 872.955 & 26,66 \\
\hline Esporte, cultura ou lazer & 368.499 & 11,25 \\
\hline Atividade política & 308.314 & 9,42 \\
\hline Outros & 1.548 .051 & 47,28 \\
\hline
\end{tabular}

Fonte: elaboração a partir de IBGE - Pesquisa Mensal de Emprego - Tema Associativismo (IBGE, 1996).

(1) O total não é a soma das parcelas por tratar-se de quesito de múltipla marcação.

O segundo fator de explicação da manutenção do padrão corporativo é a ampliação da autonomia da burocracia ao longo do período analisado, que levou ao seu próprio alargamento e ao reforço de suas posições (RODRIGUES, L. M., 1990, p. 65). As burocracias ministerial e sindical, clientelas específicas desse modelo, sempre possuíram 
enorme poder para dirigir os rumos da política de organização do trabalho no país, dificultando as transformações de propostas que emergem na sociedade civil, em políticas efetivas. Além disso, ao tomar as escolhas que culminaram no modelo corporativo, essas burocracias restringiram as opções futuras de políticas, gerando efeitos de path dependence. Os elevados custos de transformação, aprendizado e coordenação são inibidores de mudanças institucionais drásticas (PIERSON, 2001, p. 414). Mesmo os setores mais dinâmicos do sindicalismo nacional desenvolveram estruturas e estratégias para operar de acordo com a lógica própria do sistema, formular demandas em seu interior e arrecadar recursos financeiros e de poder a partir da estrutura vigente.

Houve também uma acomodação à falta de competitividade representacional decorrente da unicidade e ao financiamento público. A atração de filiados foi, em decorrência desses fatores, limitada, e não dependeu da demonstração de combatividade, bastando a oferta de estruturas assistenciais. Indícios apontam, inclusive, que os sindicatos empregaram formas de controle do número de filiados para evitar a concorrência eleitoral e garantir a manutenção das mesmas lideranças e para limitar o número de filados à capacidade de oferta de serviços. Esses mecanismos são comprovados pelo desestímulo à filiação quando o número de membros de um sindicato superava sua capacidade de oferecer os serviços assistenciais, bem como em períodos anteriores às eleições. Apenas o novo sindicalismo, em sua luta para alijar as lideranças tradicionais do poder sindical, promoveu esforços para a filiação, com o intuito de provocar surpresas eleitorais (CARDOSO, A. M., 2001). Ainda assim, mais da metade dos sindicatos no país congrega menos de 500 filiados e pouco mais de $5 \%$ dos sindicatos possuem mais de 5 mil filiados (IBGE, 2003, p. 118). Dessa forma, a eliminação da estrutura vigente de financiamento e representação de toda a categoria representaria elevados custos de reorganização e campanhas de atração de filiados para compensar os recursos provenientes do imposto sindical.

De qualquer forma, é mais importante refletir sobre as conseqüências da manutenção do modelo. Conformado a partir de propostas autoritárias, perpetuador de um padrão próprio de vida cívica e de direcionamento da ação coletiva e limitado pelo comprometimento de sua base de reprodução - o trabalho assalariado formal - o padrão não representou a possibilidade de uma ação social autônoma.

Pela regulação jurídica da existência, organização e possibilidades dos sindicatos, o Estado transformou essas associações, de uma unidade de ação coletiva dos trabalhadores, 
em um instrumento para a conformação das condições objetivas exigidas pela sociedade capitalista (MARTINS, 1989, p. 185). A conjugação de unicidade sindical, a contribuição oficial obrigatória, a extensão das conquistas da categoria para todos os seus membros, independentemente de sua filiação, a heteronomia perante o Ministério do Trabalho e os laços com a administração pública comprometeram os incentivos a uma ação sindical dinâmica e combativa. As lideranças sindicais tornaram-se burocratas e, contemporaneamente, gestoras de fundos públicos vinculados ao trabalho, concorrendo por recursos orçamentários (OLIVEIRA, F., 2006, p. 146). Sua tarefa é, tal qual a de Sísifo: conquistar os recursos financeiros e eleitorais para se manter no poder e, com isso, buscar mais recursos. Tem-se ai, portanto, outra razão para o apego dos trabalhadores à regulação jurídica das relações de trabalho. Preferem ter as condições de seu contrato definidas geral e abstratamente por lei do que comprometer seus direitos enfrentando duras negociações entre um patronato conservador, sob intensa pressão por ampliar a competitividade e interessado em ampliar seu poder discricionário sobre a forma de contratar, utilizar e demitir mão-de-obra, e líderes sindicais pouco combativos (CARDOSO, A. M., 1997).

Ao longo de mais de sete décadas de existência e consolidação, o modelo tem promovido e institucionalizado, como aponta Guilherme dos Santos (1979, p. 70), uma cidadania regulada. Trata-se de um padrão próprio de reconhecimento cívico e condicionado à ação e à estrutura do conflito social por meio do atrelamento da proteção social ao reconhecimento profissional. A constelação de direitos associados ao mundo do trabalho, instrumento de regulação jurídica e reprodução social da força de trabalho subordinou-se, no Brasil, ao reconhecimento oficial da ocupação profissional. O símbolo desse padrão de reconhecimento cívico é o emprego formal, registrado na carteira de trabalho, e seu produto a consagração jurídica e institucional das desigualdades ocupacionais. A ação, por sua vez, é corporativamente estruturada e depende da prévia legitimação do ator pelo Estado, perante o qual se processa.

Ademais, o modelo corporativo de intervenção social brasileiro determinou o modo de processamento dos conflitos pelo Estado, a partir do reconhecimento profissional, o que o tornou sistemicamente incapaz de lidar com movimentos e demandas que ocorrem à margem das relações de emprego formal. Em um momento em que essas relações perdem espaço para o subemprego e para o emprego informal, esse modelo perde em absoluto sua capacidade operacional e torna-se ainda mais excludente do que era na época do assalariamento maciço. A limitação da proteção ao trabalho formal, isto é, à relação de 
emprego e a conseqüente associação de todas as demais formas de trabalho com a marginalidade age como um mecanismo de dupla exclusão. Em primeiro lugar, exclui os trabalhadores sob condições diversas daquelas prescritas pela CLT da proteção conferida pela regulação jurídica das relações de trabalho. Em segundo lugar, exclui esses trabalhadores da proteção social.

$\mathrm{Na}$ análise formal, fundada nos elementos legislativos e institucionais que compõem o modelo, assim como nos registros oficiais, a exclusão sempre crescente dos trabalhadores das relações formais e a paralela ampliação de relações de trabalho diversas, que escapam à regulação estatal, é dado que passa, por vezes, despercebido. As análises da regulação do trabalho e da ação sindical comumente concentram-se na legislação, incluindo dados a respeito de seu desempenho, mas freqüentemente desconsiderando dados a respeito das práticas que transcendem os padrões legais e institucionais. As crescentes práticas de trabalho exercidas sob condições diversas daquelas estabelecidas na legislação continuam à margem das análises que, como afirma Adalberto Cardoso (1997, p. 99), julgam ser possível derivar a realidade da letra da lei.

Ainda que se trate de um fenômeno de difícil verificação empírica, o crescimento de outras formas de trabalho não cobertas pela legislação não pode ser negado. Há um número crescente de relações de trabalho e práticas negociais, envolvendo inclusive sindicatos, à margem da lei. Ademais, os atores têm cada vez mais prescindido do aparato jurídico para solucionar conflitos e regular suas relações. Atualmente, a Justiça do Trabalho não é o principal meio de negociação das condições de trabalho e as soluções negociadas pelas partes preponderam sobre acordos homologados e sentenças normativas de dissídios coletivos (CARDOSO, A. M., 1997, p. 99, 109; DIEESE, 2006, p. 8). De acordo com dados da Pesquisa Sindical, realizada pelo IBGE em 2001, 80,3\% (35.362) das negociações coletivas realizadas no Brasil naquele ano foram fruto de acordos e convenções coletivas, e apenas 12,4\% (5.471) foram realizadas por meio de dissídios, sendo os restantes 7,3\% (3.232) negociações não concluídas até o final do ano (IBGE, 2003, p. 163). O DIEESE, empregando base amostral diversa, apontou um índice ínfimo de intervenção da Justiça do Trabalho nas negociações coletivas em apenas 1,1\% dos casos em 2004 (DIEESE, 2006, p. 8).

A co-existência dessas práticas com relações formais de emprego e a permanência da CLT como pedra angular de regulação do trabalho inaugura um sistema híbrido, reflexo dessa dupla realidade. De um lado tem-se o sistema formalizado de emprego, que goza de 
proteção e regulação jurídica. Do outro, todas as práticas não reconhecidas por esse sistema rígido e, desse modo, reputadas como informais.

Apesar da manutenção dos pilares do sistema de regulação jurídica, todos os atores adaptam-se a essa nova realidade, cujo caráter híbrido conta com o apreço de, ao menos, alguns de seus representantes. Empresários vêem nele a oportunidade para empregar a força de trabalho com maior flexibilidade, o que atende às demandas de novos arranjos produtivos e uma demanda flutuante. Trabalhadores excluídos do mercado beneficiam-se com a expansão dos postos de trabalho e agradecem a oportunidade de obter novamente meios para subsistência. O governo, por fim, administra o desemprego sem o desgaste de uma reforma trabalhista. O sistema perdura, portanto, também porque os atores têm se movimentado à margem dele, prescindindo dele para engendrar e regular as relações cotidianas no mundo do trabalho. Mesmo alguns sindicatos têm sabido incorporar essa realidade em sua lógica de funcionamento e passam a negociar melhores condições para os trabalhadores nesses arranjos flexíveis e informais, além de incorporar trabalhadores sob regimes diversos daquele previsto na CLT a seu corpo de filiados (CARDOSO, A. M., 1997). Ainda assim, resta evidente que o marco regulatório existente não capacita os sindicatos a enfrentar os desafios representados pela flexibilização dos padrões de uso do trabalho. 


\title{
3. Unidos, Nós Perdemos: A Regulação Do Trabalho Na Grã- BRETANHA
}

\begin{abstract}
O negócio é realmente muito simples [...]. Deixe os trabalhadores e seus empregadores tanto quanto possível em liberdade para fazer suas próprias barganhas em seu próprio modo. Este é o meio de prevenir disputas... (Conselho de Francis Place ao parlamentar Joseph Hume, em meio ao debate sobre a revogação do Combination Act, em 1824, apud THOMPSON, 1966, p. 519. Traduz-se ${ }^{59}$ ).
\end{abstract}

Nenhum estado, ainda que benevolente, pode desempenhar a função dos sindicatos de permitir aos trabalhadores decidirem por si próprios como seus interesses podem ser melhor salvaguardados. É onde os sindicatos não são competentes, e reconhecem que eles não são competentes para desempenhar uma função, que eles aceitam o Estado desempenhando um papel de ao menos garantir padrões mínimos, mas na Grã-Bretanha esse papel é reconhecido como a segunda melhor alternativa (Depoimento do Trades Union Congress à Comissão Real sobre Sindicatos e Associações de Empresários em 1966, apud HYMAN, 2003, p. 46. Traduz-se ${ }^{60}$ ).

Francis Place ${ }^{61}$, o agitador político que defendia a revogação da legislação proibitiva das associações de trabalhadores na segunda década do século XIX, jamais conheceu o Trades Union Congress (TUC) e tampouco poderia imaginar que os movimentos operários atingiriam no século XX tamanho grau de influência política, social e econômica na Grã-Bretanha a ponto de mobilizarem, por três anos (1965-8), uma comissão real formada por políticos, sindicalistas, empresários e notáveis estudiosos das

59 No original: "The business is really very simple [...]. Leave workmen and their employers as much as possible at liberty to make their own bargains in their own way. This is the way to prevent disputes...” (THOMPSON, 1966, p. 519).

${ }^{60}$ No original: no state, however benevolent, can perform the function of trade unions in enabling workpeople themselves to decide how their interests can best be safeguarded. It is where trade unions are not competent, and recognise that they are not competent, to perform a function, that they welcome the state playing a role in at least enforcing minimum standards, but in Britain this role is recognised as the second best alternative (HYMAN, 2003, p. 46).

${ }^{61}$ Francis Place foi um agitador político do início do século XIX, um dos primeiros porta-vozes do sindicalismo britânico. Após envolver-se em greves da indústria de couro de Londres, não mais conseguiu empregar-se e decidiu educar-se por meio da leitura. Conseguiu retomar a vida profissional como alfaiate, mas nunca abandonou as campanhas por reformas políticas e sociais. Place era influente junto a alguns membros radicais do parlamento e costuma municiá-los de informações e argumentos para propor reformas (REID, 2005, pp 27-9). Era próximo dos círculos liberais radicais e acreditava fortemente nas benesses de um mercado livre. O papel de intermediação dos interesses dos trabalhadores perante a Câmara dos Comuns valeu-lhe grande apreço pela historiografia do movimento operário produzida no final do século XIX e início do século XX (especialmente pelos fabianos Beatrice e Sidney Webb), que o retratava como o herói solitário que, com suas forças e diante da apatia dos sindicatos, logrou mobilizar a opinião na Câmara dos Comuns e na sociedade contra a proibição legal às associações de trabalhadores. Sabe-se, atualmente, que Place não estava sozinho e que sua luta não tinha como particular objetivo fortalecer os sindicatos mas, na esteira de seus valores liberais, eliminar uma forma de repressão estatal e permitir que o mercado regulasse livremente as relações de trabalho o que conduziria, acreditava, ao desaparecimento das associações de trabalhadores (THOMPSON, 1966, pp. 516-9). 
relações de trabalho, como foi a Comissão Donovan, para a qual o depoimento acima foi oferecido como evidência. Ainda assim, Place e o TUC revelavam em suas afirmações a mesma convicção a respeito de como as relações, individuais e coletivas, estabelecidas entre empresários e trabalhadores, devem ser reguladas. Julgavam que a melhor forma de regulação dessas relações seria aquela produzida livre e coletivamente pelos próprios atores envolvidos - trabalhadores e empresários -, isto é, a auto-regulação coletiva. Por conseguinte, compartilhavam também a mesma visão a respeito do papel limitado e subsidiário da regulação estatal - incluindo a legislação - sobre as relações de trabalho. A segunda melhor solução, na acepção do TUC, não deveria jamais substituir a liberdade negocial dos atores e sua capacidade de regular coletivamente suas relações por meio de acordos.

A invocação dessa convicção nas duas afirmações, separadas por um século e meio, revelam sua permanência e força ao longo da história das relações de trabalho assalariado na Grã-Bretanha. Em realidade, essas declarações são apenas dois exemplos das inúmeras ocasiões em que, no debate público, os atores interessados reafirmaram a sua convicção no princípio estruturante da organização e regulação das relações de trabalho na Grã-Bretanha até o final da década de 1970 e que ganharia, na célebre formulação de Kahn-Freund, o título de “laissez-faire coletivo" (1954). Desse princípio derivavam, ao menos, dois corolários: o voluntarismo, expresso na preferência pela auto-regulação coletiva, em um grau elevado de autonomia em relação ao Estado e, em especial, no “abstencionismo legal” (HYMAN, 2003, p. 39); e a subjacente visão pluralista das relações de trabalho, expressa na postura de rivalidade que as partes assumiam, mesclada à disposição a concessões e acordos voluntários (idem, p. 49) ${ }^{62}$.

Esse princípio e seus corolários enraizaram-se de tal modo, que se tornaram uma convicção amplamente compartilhada entre trabalhadores e empresários, a ponto do mesmo Kahn-Freund (1956, p. 59) afirmar que a negociação coletiva havia se tornado um “costume cristalizado”, que nenhuma ação legislativa lograria modificar ${ }^{63}$. Com efeito, empresários, trabalhadores e suas associações representativas na Grã-Bretanha recorrem freqüentemente à tradição e aos costumes para justificar práticas e suas pretensões. Por força do próprio voluntarismo e da autonomia regulatória das partes, grande parte do quadro de regras que definem os direitos e obrigações de empresários e trabalhadores é

\footnotetext{
${ }^{62}$ Essa postura é o que tantos autores britânicos denominam de “adversarial tradition”.

${ }^{63}$ No original: “crystallised custom”. Kahn-Freund expressa claramente sua opinião sobre o papel que o direito pode exercer ainda em outro artigo de 1970 (Trade unions, the law and society).
} 
composto de normas informais, práticas toleradas e acordos (EDWARDS et. al., 1998, p. 3; HYMAN, 2003, p. 37).

Uma interpretação apressada poderia derivar da força e da permanência do princípio do laissez-faire coletivo algumas conclusões equivocadas sobre o sistema de regulação das relações de trabalho na Grã-Bretanha que devem ser desde já afastadas. Em primeiro lugar, a longa permanência da convicção na liberdade de negociação coletiva e o apego dos atores a costumes derivados de sua tradição negocial poderiam ser empregados para sugerir um sistema rígido, que não teria sofrido alterações. No início do século XXI, entretanto, é difícil encontrar entre as fileiras sindicais, patronais ou na burocracia estatal britânica essa mesma convicção que parecia, até a década de 1970, inabalável. Mesmo no longo período em que o princípio foi efetivamente estruturante da regulação das relações trabalhistas, houve uma série de inovações, mudanças incrementais que tardaram para se firmar, além de adaptações e concessões exigidas por situações conjunturais. O princípio era suficientemente amplo e plástico para permitir diferentes arranjos negociais e soluções regulatórias. A despeito do pluralismo e da autonomia em relação ao Estado, houve até mesmo uma curta e fracassada experiência de concerto corporativista (REGINI, 1984). De acordo com Howell (2005), o princípio comportou a estruturação de dois sistemas distintos de regulação estatal das relações de trabalho e foi influente mesmo na construção do terceiro sistema, durante o governo Thatcher, que escolheu como alvos da reforma conservadora a limitação das liberdades sindicais desenfreadas que o princípio teria produzido.

Em segundo lugar, a força desse princípio na retórica, no imaginário e nas práticas de sindicalistas e associações patronais não deve ser empregada para inferir que se tratava de uma convicção absolutamente consensual. A preferência pelo voluntarismo e o rechaço à legislação e à intervenção do Estado não eram unânimes em meio a sindicatos e empresários. A intransigente postura de afastamento do Estado foi, aliás, duramente criticada em alguns momentos. Houve críticos de ambos os lados: alguns defendiam maior atuação do Estado para garantir o reconhecimento sindical e a barganha coletiva, enquanto que outros defendiam maior responsabilidade por parte dos sindicatos, o que representava maior controle sobre sua ação. Foi justamente essa segunda crítica que, presente na narrativa dos meios de comunicação sobre a situação das relações de trabalho na década de 1970, conduziu a opinião pública a apoiar um projeto conservador de enfraquecimento dos sindicatos e erosão do laissez-faire coletivo. 
Ademais, esse princípio não determinou um único padrão de ação sindical, especialmente no que diz respeito à relação entre os sindicatos e o Estado. O sindicalismo britânico sempre foi extremamente fragmentado, reflexo primordial da economia diversificada e do choque entre associações com longa tradição histórica, ligadas a setores tradicionais e quase artesanais da produção, e os sindicatos vinculados a indústrias de produção de massa e setores de ponta da economia ${ }^{64}$. O sindicalismo emergiu na Grã-Bretanha a partir de sociedades de artesãos que abandonaram as guildas e corporações medievais em face da crescente diferenciação de interesses entre mestres e jornaleiros (REID, 2005). Ainda assim, o sindicalismo vinculado à indústria artesanal mantinha preocupações e demandas próprias das antigas associações, como os controles de qualidade dos produtos e de acesso ao mercado. No século XIX, porém, as sociedades de artesãos passam a conviver com novos sindicatos, vinculados a indústrias maiores, com processos padronizados de produção, além das organizações de trabalhadores da indústria de extração mineral e da agropecuária (THOMPSON, 1966; HYMAN, 2003; HOWELL, 2005). Essa diversificação determinou, como não poderia deixar de ser, uma multiplicidade de pretensões e formas de ação.

Contudo, a posição daqueles que defendiam a negociação coletiva como modo privilegiado de regulação das relações foi predominante e, foi ela que acabou por determinar a atuação estatal nas relações de trabalho. Mesmo em meio a essa diversidade, o corolário do voluntarismo permitiu construir uma lógica comum subjacente à relação entre sindicatos e a regulação estatal. Apresentá-la é fundamental para que se afaste uma terceira associação equivocada, entre a força do voluntarismo e do abstencionismo legal, de um lado, e ausência de um papel regulador do Estado nas relações de trabalho, de outro.

\footnotetext{
${ }^{64}$ Não se pode negar que também o sindicalismo brasileiro é diversificado e que todas as abordagens agregadas do sindicalismo, que o observam como um fenômeno único, tendem a privilegiar os movimentos operários vinculados às indústrias e serviços localizados nos grandes centros urbanos, mais organizados e com maior impacto em sua ação. Reconhecidamente esta pesquisa não é exceção. Contudo, o sindicalismo brasileiro teve sua origem vinculada ao processo de industrialização, como já sustentado. Até o final do século XIX, no país a mão-de-obra era predominantemente escrava e a relação assalariada só se generalizou como fundamento da produção na transição dos séculos. Esse período também assistirá as primeiras iniciativas industriais e, com elas, a formação das primeiras agremiações operárias. Pode-se afirmar com segurança que o sindicalismo só emergiu quando a atuação sistemática do Estado nacional passou a fomentar a industrialização e estabilizá-la. Até meados do século XX, aliás, o sindicalismo era fenômeno quase exclusivamente urbano e industrial. Portanto, o sindicalismo brasileiro compartilha experiências históricas comuns. Não é, como o britânico, cindido por tradições históricas absolutamente díspares, e esteve menos sujeito à persistência de costumes e pretensões como a demarcação de categorias profissionais e a exigência de qualificação como um meio de restringir o acesso a certos ofícios. Sua diversificação foi maior nas últimas décadas, quando se agregam ao quadro de sindicatos organizações vinculadas ao setor público e os sindicatos de categorias gerenciais.
} 
Para a maioria dos sindicatos, como afirma Hyman, “[...] o Estado não foi um foco importante de preocupação assim que o arcabouço legal básico dos 1870s foi assegurado” (2003, p. 47. Traduz-se ${ }^{65}$ ), mas a recíproca, como se buscará demonstrar, não é verdadeira. Os sindicatos foram um foco permanente de preocupação do Estado, produzindo diversas comissões parlamentares de investigação e gerando um amplo debate político sobre alternativas de intervenção e regulação das relações coletivas de trabalho.

Com efeito, os instrumentos primordiais da regulação do trabalho na Grã-Bretanha foram, até 1979, a negociação coletiva e os acordos por ela produzidos, celebrados entre sindicatos de empregados e associações patronais, ou entre aqueles e firmas. Mas o Estado, e em certa medida o direito, também tiveram seu lugar nesse sistema. A mais importante forma de intervenção estatal na regulação do trabalho foi na forma de promoção, ou às vezes até mesmo criação, de instituições permanentes e autônomas de solução de conflitos e negociação coletiva das condições de trabalho. Em alguns casos, a legislação foi além, criando direitos básicos e definindo salários, extensão da jornada de trabalho e condições básicas de trabalho. O Estado tinha, portanto, três opções de intervenção na regulação das relações de trabalho: promover instituições de negociação coletiva, criá-las ou, ainda, estipular legalmente padrões mínimos (HYMAN, 2003; HOWELL, 2005).

A opção entre essas três alternativas obedecia, como já afirmado, à uma lógica simples: a intervenção administrativa e legislativa do Estado foi inversamente proporcional à capacidade organizativa dos sindicatos e das associações patronais e, portanto, à capacidade dos atores de firmar acordos. Em nenhuma hipótese, como expressam as afirmações de Place e do TUC, a intervenção estatal deveria substituir os esforços negociais dos atores ou definir-lhes o resultado. A negociação deveria ser livre, embora em muitos casos o Estado tenha oferecido exemplos de concessões, direitos e obrigações das partes apelando para “melhores práticas” ou mesmo aplicando-as no serviço público (HOWELL, 2005, p. 43). Contudo, nos casos em que um aparato de negociação coletiva não se havia formado, em razão da deficiência organizativa das partes, dos conflitos entre sindicatos ou empresários ou da relutância destes, o Estado podia aproximar atores, persuadir empresários relutantes ou construir instituições permanentes de negociação coletiva, solucionando, assim, problemas de ação coletiva que impediam acordos. Em todos os casos, a prerrogativa sobre a definição das condições de trabalho permanecia com trabalhadores e empresários.

${ }^{65}$ No original: “[...] the state was not a major focus of concern once the basic legal framework of the 1870 s had been achieved” (HYMAN, 2003, p. 47). 
Em casos extremos, o Estado podia definir legalmente os salários e alguns padrões mínimos a serem observados na relação salarial. O emprego da legislação ocorria, habitualmente, em setores em que os trabalhadores eram muito fracos, os empresários negavam-se a negociar mesmo após a criação de aparatos pelo Estado, ou em que a competição entre firmas era muito acirrada, o que se traduzia em condições precárias e salários baixos. Nesses casos, aliás, os próprios sindicatos, impossibilitados de negociar, pressionavam o Estado para definir, por meio de leis, padrões mínimos que conferissem uma base sobre a qual negociar. A ameaça de definir legalmente salários e condições mínimas de salários foi, aliás, um instrumento eficaz para persuadir os atores a instituir mecanismos de negociação coletiva, empregado muitas vezes pelo Estado britânico (EDWARDS et. al., 1998; HOWELL, 2005).

Mas a força moral do voluntarismo não reconhecia um papel maior ao direito que o de completar os esforços dos atores para promover negociações coletivas. A fixação de condições e direitos para os trabalhadores era excepcional. Como conseqüência, até o recente governo trabalhista de Tony Blair, a existência e ação dos sindicatos esteve juridicamente fundada apenas na concessão de uma imunidade em relação ao direito consuetudinário (common $l a w^{66}$ ). Tratava-se de uma proteção meramente negativa: as ações sindicais, promovidas com o intuito de vocalizar demandas dos trabalhadores, constituíam uma esfera não sujeita ao controle e ao direito criado pelos juízes (DICKENS; HALL, 2003, p. 125). Mesmo essa imunidade geral não impediu, em diversos momentos, que juízes limitassem as possibilidades de ação ou impusessem responsabilidades sobre atos praticados por sindicatos em suas lutas cotidianas (HOWELL, 2005).

Os sindicatos não gozavam de nenhum direito ou procedimento que obrigasse as empresas a reconhecê-los diretamente como interlocutores, ou a engajar-se em negociações coletivas. Os trabalhadores, por sua vez, não tinham garantidos os direitos à filiação sindical ou à realização de greves, embora a filiação tenha se tornado, mais recentemente, uma causa injusta para demissão. Por fim, considerava-se que os acordos negociados geravam apenas uma obrigação moral, não sendo legalmente vinculantes, e que as condições negociadas só se incorporavam ao contrato individual de trabalho se as cortes assim determinassem, quando instadas nos casos concretos (HYMAN, 2003, pp. 38-9).

A regulação jurídica não foi mobilizada para criar direitos positivos para os sindicatos. Ainda assim, o sindicato era considerado peça fundamental ao funcionamento

${ }^{66}$ Sempre que o termo Common law for empregado, referir-se-á ao direito cuja fonte são os precedentes judiciais, isto é, ao direito criado pelos juízes no mundo Anglo-Saxão. 
do sistema, não apenas um órgão de colaboração com a ação administrativa do Estado ou auxiliar do Executivo. Quer pela função que o direito exerceu no aparato de regulação do trabalho na Grã-Bretanha, quer pelo papel que os sindicatos desempenhavam, o sistema construído é diametralmente oposto ao brasileiro.

Para compreender a força e permanência do laissez-faire coletivo britânico, o papel que o direito nele desempenhou e os padrões de ação sindical que produziu, é necessário reconstruir a sua trajetória de formação, apontando como o Estado o reforçou, fazendo dele a base de sua intervenção na regulação do trabalho. Todavia, antes mesmo de a convicção voluntarista formar-se e generalizar-se nos movimentos operários e nas associações patronais, o Estado Britânico já intervinha no mercado de trabalho de modo a regulá-lo. A própria formação de um mercado de trabalho assalariado contou com a ação intensa da Coroa e do Parlamento britânicos. A particular posição dos atores e, em especial dos trabalhadores, em relação ao direito e ao Estado só é explicada a partir dessa ação regulatória do Estado e de suas interferências sobre a formação da classe trabalhadora e de seus movimentos. Foi no duplo movimento dos trabalhadores e suas associações pela reforma política e pela revogação da legislação repressiva sobre ação sindical, bem representado pela figura de Francis Place, que a convicção voluntarista aparece pela primeira vez, embora o Estado só venha a adotá-la formalmente como princípio orientador de uma política sistemática e coerente de intervenção na regulação do trabalho em 1906, com a edição do Trades Dispute Act (EDWARDS et. al., 1998, p. 5; HYMAN, 2003, p. 59). Esse seria, aliás, o ponto de partida de uma longa ação regulatória do Estado no sentido de construir instituições de negociação coletiva (HOWELL, 2005). A seguir, para investigar as razões de sua erosão, é necessário compreender os ataques que ele sofreu nas últimas décadas, quais as iniciativas de reforma apresentadas e qual o modelo que veio efetivamente a substituí-lo.

\subsection{A regulação jurídica na produção do trabalho assalariado}

Na Grã-Bretanha, o marco inicial da regulação jurídica das relações de trabalho corresponde ao momento de formação de uma massa de assalariados e de construção do mercado em que seu trabalho é colocado à venda. É certo que, tão logo se forma um agrupamento que vive do trabalho, e do qual a produção depende, mecanismos regulatórios 
já devem estar em funcionamento para aproximar compradores e vendedores e, sobretudo, para processar os conflitos que emergem da relação conflituosa que estabelecem entre si trabalhadores e empresários. No caso britânico, contudo, as primeiras práticas e políticas regulatórias coincidiram com a própria constituição de um agrupamento que vive do trabalho e, assim sendo, antecederam a sua transformação em uma classe social. O direito foi empregado para promover os processos de formação da massa de assalariados. Por assim dizer, a regulação da oferta de trabalho constituiu a primeira ação estatal sobre o mundo do trabalho.

A ação estatal na formação de uma massa de assalariados e na conformação de um mercado de trabalho tem sido o objeto de excelentes relatos históricos (THOMPSON, 1966; MARX, 1975; POLANYI, 2000). Esses relatos descrevem como o Estado Britânico comandou, ou ao menos legitimou, os longos processos de expropriação de terras dos camponeses e os cercamentos de terras comunais, que tiveram início no reinado de Elizabeth, ganharam ímpeto após a Revolução Gloriosa e completaram-se apenas no início do século XIX, quando todas as reminiscências da legislação dos Tudors e dos primeiros reis Stuarts protegendo os camponeses contra a expulsão do campo, assim como as forças políticas que as sustentavam, foram finalmente repelidas. A resistência de forças políticas, majoritariamente vinculadas a uma nobreza da terra com feições paternalistas, a esses processos, foi fundamental ao êxito do mesmo, como argumenta Polanyi (2000), por reduzir a velocidade das transformações sociais. Assim, foi possível à sociedade britânica absorver as profundas mudanças pelas quais passava na direção de uma sociedade capitalista e evitar os efeitos catastróficos do despovoamento repentino do campo e o deslocamento das massas expropriadas para os centros urbanos.

Polanyi (2000) e Marx (1975) afirmam que, até o século XVIII, a expropriação foi um produto fundamentalmente da violência individual praticada pelos proprietários de terras. Diversos atos legislativos buscaram proteger as terras comunais, no intuito de evitar o despovoamento do campo e conter a formação do que se considerava uma massa de desocupados que ameaçavam a ordem pública perambulando pelas cidades. Entretanto, a legislação foi ineficiente para obstruir a ação voraz dos proprietários. A partir do século XVIII, a legislação inverteu sua orientação e passou a promover os cercamentos, refletindo a nova mentalidade da elite política britânica após a Revolução Gloriosa. Ao menos a partir desse período, a regulação jurídica desempenhou um papel importante nesse processo. 
Em seus relatos, Polanyi (2000) e Marx (1975) não deixam dúvidas sobre a centralidade dos cercamentos para a constituição das bases materiais do desenvolvimento capitalista das ilhas britânicas. Capital e trabalho foram produzidos por meio desse processo. Ao permitir a conversão de terras aráveis comuns em pastos, os cercamentos possibilitaram um incremento significativo da produção de lã e forneceram o capital excedente que, mais tarde, seria empregado no processo de industrialização. Constituíram, portanto, um dos fundamentos da acumulação primitiva. Ao expropriar os camponeses de seus meios independentes de subsistência, por sua vez, os cercamentos criaram um enorme exército que constituiria uma massa de proletários livres, garantindo a oferta de mão-deobra para as oficinas urbanas.

A medida foi apenas a primeira de uma série para eliminar as alternativas de subsistência dos camponeses independentes e pequenos proprietários agrícolas e, assim, assegurar a disponibilidade de trabalhadores nos centros industriais. Além de eliminar seus meios tradicionais de subsistência, era necessário discipliná-los para a relação salarial, fazê-los aceitar as condições degradantes de trabalho na incipiente manufatura britânica, e garantir a sua reprodução, regulando assim a oferta de trabalho no mercado. Por assim dizer, era necessário transformar a massa despropriada em proletários urbanos, um processo que Offe e Lenhardt (1990) denominam de “proletarização ativa”.

Foi com esse espírito que todo um edifício legislativo e regulatório foi produzido, disciplinando, no plano geral, os expropriados, e no plano específico, os pedintes que proliferavam nas cidades. A legislação contra a vadiagem e as Poor Laws (leis dos pobres) desempenharam o duplo papel de instilar a disciplina para o trabalho e de assegurar condições mínimas para sua reprodução, estabelecendo benefícios a serem distribuídos aos pobres pelas paróquias ${ }^{67}$. Essa legislação, que mesclava o paternalismo com a ética do trabalho, tratava os miseráveis que não tinham condições de sobreviver com seus próprios meios como incapazes, que necessitariam de orientação para se tornar sujeitos produtivos. Por essa razão, condenava-os ao confinamento em workhouses (casas de trabalho), onde os trabalhadores deveriam ser socializados nos valores do "trabalho, disciplina e moderação" (THOMPSON, 1966, p. 267. Traduz-se ${ }^{68}$ ). A lei dispunha que a condição dos pobres no

\footnotetext{
${ }^{67}$ A respeito do emprego da legislação de caráter penal contra a vadiagem e das Workhouses inglesas para regular a oferta de mão-de-obra no mercado e promover a disciplina do trabalho, ver Rüsche e Kirchheimer (1984).

${ }^{68}$ No original: “labour, discipline and restraint” (THOMPSON, 1966, p. 267).
} 
interior das workhouses deveria ser pior do que aquelas verificadas entre os trabalhadores exercendo as piores ocupações em seu exterior (idem, p. 267).

Essa legislação foi complementada por documentos legais que almejavam regular as relações de trabalho no campo e nas oficinas urbanas. Os legisladores tinham a difícil tarefa de conjugar a avidez dos empresários para aumentar a exploração do trabalho e, com ela, o lucro, com a necessidade de assegurar a subsistência dos trabalhadores, reduzindo a jornada de trabalho e criando padrões mínimos a serem observados pelos patrões. Essa legislação também pretendia regular a oferta de trabalhadores no mercado e contornar as flutuações populacionais causadas por epidemias, guerras e fluxos migratórios (MARX, 1975, cap. VIII). Quando essas circunstâncias conduziam a uma escassez de mão-de-obra, medidas protetivas eram editadas, juntamente com disposições que reduziam a mobilidade dos trabalhadores e definiam salários, para evitar que a baixa competição no mercado de trabalho gerasse salários muito elevados. Quando, ao contrário, havia excedente de mãode-obra no mercado, permitia-se a livre competição entre trabalhadores, ainda que isso representasse um considerável agravamento das condições de trabalho e redução dos salários. Entretanto, legislação também era produzida nessas ocasiões, sempre que os salários tornavam-se menores do que os necessários à subsistência dos trabalhadores, para garantir a reprodução da força de trabalho (STEINFELD, 2001, p. 88; REID, 2005, p. 15). A primeira lei dessa natureza foi editada no século XIV, como resposta à Peste Negra. O documento reduzia a jornada de trabalho para 12 horas, fixava salários máximos e restringia a mobilidade dos trabalhadores (REID, 2005, p. 14). Sucessivas leis modificaram a jornada máxima permitida, inicialmente aumentando-a e, mais tarde, reduzindo-a, primeiro para crianças, adolescentes e mulheres para, só então, incluir os homens. Contudo, a ausência de sanções e mecanismos que possibilitassem sua aplicação permitia ao empresariado definir as condições que melhor lhe aprouvesse, como demonstram os relatórios dos inspetores de fábricas, que protestavam em vão contra o desrespeito à legislação (MARX, 1975, cap. VIII). No que diz respeito à fixação dos salários, a solução preferida foi conferir aos juízes de paz dos condados o poder de determinar salários das categorias em cada localidade, evitando-se assim a rigidez da legislação nacional (REID, 2005, p. 14).

Em meio a essa legislação esparsa, produzida ao longo dos séculos de formação da sociedade capitalista britânica, um documento legal, editado pela Rainha Elizabeth em 1563, merece destaque. Trata-se do Statute of Artificers (Estatuto dos Artífices), que 
vigorou até a segunda metade do século XIX, contendo diversos dispositivos que regulavam a relação entre os mestres e os artesãos. Sua importância derivou não apenas do fato de ser um documento mais longevo, que estendeu seus efeitos sobre as relações de trabalho por quatro séculos, mas também por ser mais abrangente. O Statute era aplicável a todos os artesãos ${ }^{69}$ e regulava uma série de aspectos do contrato de trabalho que esses estabeleciam com os mestres. No período em que esteve em vigor, o termo "artesão" confundia-se com "trabalhador", já que as oficinas artesanais representavam a forma predominante de organização da produção até o século XIX, e perduraram em setores industriais britânicos mesmo no século XX (HOWELL, 2005, p. 50). Logo, a lei regulava a relação de trabalho típica até o século XIX, determinando os direitos e obrigações de mestres e artesãos, bem como conferindo aos juízes de paz dos condados a competência para dirimir disputas sobre salários (STEINFELD, 2001, p. 102).

Como um produto do Renascimento, emendado algumas vezes, a lei refletia uma organização do trabalho própria de seu tempo, com mestres, artesãos jornaleiros e aprendizes, desempenhando ofícios organizados em guildas e corporações que controlavam os mercados e a qualidade dos produtos. Nesse sentido, o Statute of Artificers incluía dispositivos de interesse dos artesãos, sendo os mais significativos e polêmicos as cláusulas que restringiam o aprendizado. Esses dispositivos limitavam o número de novos aprendizes nos ofícios e ampliavam a duração do aprendizado, reduzindo a futura competição que esses fariam aos artesãos e impedindo que essa categoria fosse empregada, pelo seu baixo custo, para substituir artesãos. Operacionalmente, as restrições criadas pela lei determinavam a duração do aprendizado em sete anos e a proporção entre artesãos e aprendizes foi fixada em três para um (REID, 2005, p. 15). Esses dispositivos mostraramse relevantes para a história do sindicalismo britânico por fixar juridicamente uma cisão entre dois grupos de trabalhadores - os qualificados para o exercício dos ofícios e os não qualificados - que perdia o sentido com o passar do tempo.

Ainda que o Statute atendesse ao interesse de preservação da demarcação ocupacional dos artesãos, uma análise geral do documento revela que, longe de criar condições benéficas aos trabalhadores, ele instituía um desequilíbrio de obrigações entre mestres e artesãos em favor dos primeiros. Quando a desigualdade não estava explícita na lei, a interpretação de suas regras pelos juízes assegurava aos mestres condições mais benéficas. Ao mestre, por um lado, era conferida a discricionariedade para extinguir o

${ }^{69} \mathrm{O}$ Statute of Artificers dos Tudors valia apenas para a Inglaterra, mas e Escócia adotou dispositivos legais semelhantes no século XVII (REID, 2005, p. 15). 
contrato, desde que saldasse os valores devidos ao trabalhador. Este, por outro lado, ficava impedido de terminar sua relação com o patrão, a menos que houvesse sido contratado por tempo determinado ou para executar um determinado número de peças. A legislação considerava que o trabalhador não podia deixar seu mestre antes de cumprir as obrigações definidas em contrato. Nos casos em que o trabalhador estabelecia um contrato por tempo determinado, sua obrigação genérica era executar seu ofício, sem prazo para terminar. Enquanto o mestre desejasse manter o trabalhador e pagasse seus salários, as obrigações desses não terminavam. Logo, se um artesão deixasse de trabalhar para seu mestre, por qualquer razão, estaria descumprindo seu contrato. Nas outras duas modalidades de contratação - por termo fixo ou por peças - a lei e a construção jurisprudencial asseguraram o direito do mestre de exigir a permanência do trabalhador durante o período acordado ou até que cumprisse a meta de produção estipulada (STEINFELD, 2001, pp. 967). A lei determinava punição penal, normalmente de trabalhos forçados, além da reparação civil, para os trabalhadores que deixassem seu trabalho (THOMPSON, 1966, p. 507).

Embora datasse do final do século XVI, o espírito liberal já se mostrava presente na legislação. A fixação do trabalhador a seu patrão estava fundada na obrigação de cumprir os termos acordados no contrato de trabalho e, desse modo, pressupunha que houvesse negociação livre dos termos contratuais. Sabe-se, porém, que as condições eram impostas. Algumas associações independentes de artesãos, fundadas desde o final do século XVIII, tornaram-se suficientemente fortes para negociar condições de trabalho e para dirigir aos juízes de paz reclamações sobre o descumprimento contratual pelos seus empregadores, especialmente no tocante a salários (REID, 2005, p. 9). Contudo, a lei impedia na prática quaisquer formas de manifestação e de demanda que representassem o abandono dos postos de trabalho, bem como a associação de artesãos, conferindo aos juízes de paz o poder de “[...] proibir ‘confederações e conspirações’ de trabalhadores em busca de seus interesses [...]” (idem, p. 15, Traduz-se ${ }^{70}$ ). Além disso, o Statute of Artificers foi interpretado de modo restritivo pelos juízes de paz, que, a despeito da permissão expressa pela lei, entenderam que não poderiam interferir em reclamações de trabalhadores sobre salários, quer pelo não pagamento, quer pelo pagamento de um valor diferente do que o fixado (STEINFELD, 2001, p. 102).

\footnotetext{
${ }^{70}$ No original: “[...] prohibit 'confederacies and conspiracies' of workmen in pursuit of their interest [...]" (REID, 2005, p. 15)
} 
Todos esses exemplos demonstram o importante papel que o direito desempenhou na formação da massa de assalariados e de seu mercado, bem como na regulação da relação de trabalho em seus primeiros momentos. Para tanto, valeu-se regularmente da produção legislativa. Entretanto, essa legislação não incluía entre seus objetivos explícitos a regulação dos conflitos de classe ou, simplesmente, da ação coletiva dos trabalhadores. É verdade que o Statute of Artificers assegurava a punição criminal e civil dos trabalhadores que, ao envolver-se em manifestações coletivas, estariam, simultaneamente, praticando conspirações e violando suas obrigações contratuais. Ainda assim, as primeiras organizações de trabalhadores conseguiram se formar, em meio à inconstante aplicação da lei pelos juízes de paz, nas diferentes partes da Inglaterra e contra diferentes associações de artesãos (REID, 2005, p. 15).

Além disso, até o início do século XVIII, nenhuma lei teve como objetivo primordial restringir a ação coletiva dos trabalhadores. Não havia necessidade de produzir uma legislação especifica endereçada aos conflitos coletivos emergentes da relação de trabalho porque, quando ocorriam, esses eram episódicos e isolados. Antes do século XVIII, de acordo com o célebre o marco fixado por Thompson (1966), não se pode dizer que se houvesse constituído um movimento operário ou uma classe trabalhadora, consciente de sua condição comum, e organizada para reivindicar o reconhecimento de seu lugar na sociedade industrial. Essa constituição inicia-se no final desse século, com a revolução industrial, mas só irá se completar no século XIX. Além de ocupar a mesma posição na estrutura de distribuição da riqueza social - um estado objetivo - a formação do operariado em classe exigia o reconhecimento coletivo dessa condição comum pelas consciências individuais - um estado subjetivo. A fragmentação dos trabalhadores e a orientação de suas associações para questões de interesse de cada profissão, como se abordará a seguir, impediam a emergência dessa consciência de classe e da percepção de propósitos comuns. Apenas na década de 1830, afirma Thompson, surgirá “a consciência de uma identidade de interesses entre todos os diferentes grupos de trabalhadores e contra o interesse de outras classes” (1966, p. 194. Traduz-se ${ }^{71}$ ).

Do conjunto de atos jurídicos produzidos pelo Estado para regular a oferta e as condições de trabalho destacam-se duas características que o tornam relevante para o período posterior: em primeiro lugar, o tratamento penal da violação ao contrato de trabalho e da ação coletiva dos trabalhadores; em segundo lugar, o estabelecimento de uma

\footnotetext{
${ }^{71}$ No original: "the consciousness of an identity of interests as between all these diverse groups of working people and as against the interests of other classes” (THOMPSON, 1966, p. 194).
} 
desigualdade jurídica que se materializava em um tratamento assimétrico, em prejuízo dos trabalhadores.

\subsection{A proibição da ação sindical e as duas frentes de batalha}

3.2.1. As primeiras associações de trabalhadores - o mercado como fator de fragmentação

A pesquisa histórica já demonstrou que as primeiras associações de trabalhadores originaram-se a partir da cisão de guildas. Com a evolução do sistema artesanal e, depois, o fabril, os interesses de mestres e jornaleiros tornavam-se cada vez mais diferenciados, sendo que os últimos buscavam formas de organização próprias. As primeiras associações independentes formadas apenas por jornaleiros de que se tem notícia foram formadas no século XVII, embora ainda predominassem, nesse período, as corporações e guildas reunindo todos os membros de um ofício em um espírito comum de camaradagem e controle do mercado e da qualidade dos produtos. No final do século seguinte, porém, as associações de artesãos já haviam se firmado permanentemente. A ruptura com seu passado era, porém, apenas limitada. Mantinham símbolos, procedimentos e demandas próprias das guildas. Inicialmente, assumiram papéis de sociedades de auxílio mútuo e de auto-regulação dos ofícios, com determinação das tarefas a serem exercidas no trabalho por diferentes membros segundo sua qualificação e idade (REID, 2005, pp. 9-14). Receosos da competição profissional, controlavam rigidamente o aprendizado, única forma de acesso ao mercado de trabalho e defendiam demarcações tradicionais na organização do trabalho Essa atitude os tornava pouco dispostos a aceitar mudanças no processo produtivo (HYMAN, 2003, p. 42).

Ainda assim, o convívio e o compartilhamento de tradições foram imprescindíveis para que emergisse um hábito de cooperação em torno de interesses comuns. Se, em um primeiro momento, essa cooperação era empregada para auxiliar membros em situação de necessidade ou para controlar as formas de execução do ofício artesanal, logo se torna um meio de pleitear melhores condições de trabalho e salários mais elevados. Afinal, além do ofício, também as relações de trabalho estabelecidas com o mestre eram comuns aos artesãos vinculados a uma associação. Esse convívio entre comuns constitui, portanto, a 
raiz do sindicalismo moderno, isto é, das organizações permanentes voltadas para a promoção de interesses econômicos de categorias profissionais. Duas evidências da paulatina transformação dessas associações no que se convencionará denominar sindicato são os registros de suas ações e das respostas de mestres e das autoridades que a elas se seguiram. Há, já no século XVII, inúmeros registros de ações próprias do sindicalismo, como greves e o abandono dos postos de trabalho, sempre acompanhadas de procissões em que se exibiam símbolos próprios. À medida que os mestres tornavam-se incapazes de controlar o comportamento de seus artesãos, também se organizavam para pressionar o Parlamento pela produção de uma legislação que reprimisse as associações dos artesãos e seus atos (REID, 2005, pp. 10-1).

A importância dessas associações de artesãos deve-se, ainda, à influência e longevidade e de suas formas de organização e demandas. A influência está associada à sua posição de pioneirismo. Como os primeiros trabalhadores organizados, suas tradições políticas e culturais constituíram uma referência para outros grupos de trabalhadores que desejavam perseguir propósitos semelhantes (THOMPSON, 1966, p. 193). Em especial, os sindicatos de profissões artesanais destacaram-se por desenvolverem estruturas organizacionais mais elaboradas e geograficamente abrangentes, além de liderarem movimentos políticos e a formação de ligas e confederações que almejavam coordenar esforços entre sindicatos nas difíceis disputas políticas e legais em que se viram envolvidos no século XIX (REID, 2005).

A longevidade, por sua vez, tem sua razão de ser na persistência das formas artesanais de produção na Grã-Bretanha. A marcha de industrialização na Grã-Bretanha transformou o país na “oficina mecânica do mundo” (HOBSBAWM, 1978), monopolista na produção e exportação de bens e capitais por algumas décadas. Contudo, essa posição não foi atingida por meio de uma produção fabril de larga-escala e com amplo emprego de capital fixo ou novas formas de tecnologia. Em realidade, foi o grande número de pequenas fábricas, empregando métodos artesanais, que promoveu a grande acumulação capitalista nos séculos XVIII e XIX (HYMAN, 2003, p. 41). O crescimento da produção era baseado na adição de novas unidades de trabalho ou capital, e não na utilização mais eficiente do capital ou trabalho existentes. Conseqüentemente, o desenvolvimento industrial britânico dependeu das qualificações tradicionais e da versatilidade dos artesãos (idem, p. 42).

Até o século XX, a maior parte da produção britânica provinha de indústrias rudimentares, com métodos artesanais e rígidas demarcações profissionais. Entretanto, a 
partir do século XIX, surgem novas indústrias na Grã-Bretanha destinadas à produção de bens padronizados em massa. Indústrias de bens duráveis, eletricidade e químicos constituíam grandes empresas com relativo controle de seus respectivos setores e poucos concorrentes. Essas empresas introduziram os primeiros sistemas de gerência científica e controle dos processos, ausentes na indústria rudimentar. O trabalho nessas novas indústrias diferia, completamente, das formas artesanais empregadas nas outras: a produção não dependia de saberes tradicionais dominados pelos trabalhadores e, por isso, a mobilidade era maior; os processos de trabalho não eram controlados pelos próprios produtores, e sim por gerentes; e os territórios ocupacionais menos rígidos (HOWELL, 2005, p. 50; HYMAN, 2003, p. 42).

A esses dois grupos de trabalhadores distintos, somam-se muitos outros, com tradições organizacionais próprias. Reid (2005, pp. ix-x), por exemplo, acrescenta às duas categorias apresentadas uma terceira, com formas e problemas de organização próprios. Trata-se de todos os trabalhadores que realizam tarefas manuais gerais, que não exigem qualificação, em áreas como a agropecuária, extração mineral ou serviços gerais. Além dessas, poder-se-ia acrescentar outras que surgiram com o desenvolvimento econômico da Grã-Bretanha, como os trabalhadores qualificados do setor de serviços que, desde o século XIX, com o início da perda da posição relativa da manufatura britânica no comércio mundial, vem se tornando a principal fonte de recursos da economia nacional (HOWELL, 2005).

A conclusão geral que pode se extrair desse quadro é que a organização produtiva na Grã-Bretanha tem sido marcada por uma considerável diversidade desde o início da revolução industrial. Como conseqüência, também os atores envolvidos estão sujeitos a condições diversas, o que gera problemas de organização, interesses, demandas e formas de ação próprias. Essa fragmentação crescente entre os trabalhadores é um dado característico do capitalismo avançado e estava presente mesmo no Brasil no século $\mathrm{XX}^{72}$. Entretanto, como algumas dessas categorias de trabalhadores, com interesses e formas de organização variável, já existiam na Grã-Bretanha antes mesmo da formação de uma consciência comum de classe, suas arraigadas tradições foram muito relevantes para a formação do sindicalismo moderno e seus padrões de ação (REID, 2005). De início, essa

\footnotetext{
${ }^{72}$ Portanto, a razão para explorar essa diversidade no caso britânico e não fazê-lo no Brasil não é a menor diversificação dos atores coletivos no Brasil, mas sim o fato de que nas circunstâncias que se desenvolveu o sindicalismo brasileiro, esse dado foi menos relevante para explicar padrões de relação dos sindicatos com o Estado.
} 
diversidade impedia a formação de uma consciência comum e a união de forças para superar o quadro legal e político adverso.

Um episódio específico demonstra a divisão dos interesses dos trabalhadores, já no século XIX. Em 1814, para fazer frente à demanda por mão-de-obra em setores essenciais à guerra, o Parlamento decidiu revogar as cláusulas de restrição de aprendizado do Statute of Artificers, que já não eram mais cumpridas com rigor. Imaginava, assim, eliminar o controle sobre o acesso ao mercado de trabalho e permitir a entrada imediata de tantos trabalhadores novatos nas oficinas quantos fossem necessários, sem os longos períodos de aprendizado ou o respeito a cotas. A medida foi bem recebida pelos empresários, que puderam, assim, contratar mais trabalhadores na qualidade de aprendizes, reduzindo os custos com mão-de-obra. Também os trabalhadores não qualificados, cujas oportunidades no mercado eram limitadas, festejaram a medida e a corrosão das demarcações profissionais. Os artesãos, porém, reagiram vigorosamente contra a medida, que corroia sua identidade e o valor de seu maior tesouro, a qualificação (THOMPSON, 1966, p. 258). Os clubes de artesãos organizaram uma vigorosa reação à medida, opondo-se a outros trabalhadores, sem treinamento, que se uniram aos empresários para garantir que a revogação fosse mantida no Parlamento.

Mesmo após a superação, entretanto, de um marco legal que restringia a ação sindical, essa diversidade de atores continuou criando importantes problemas de coordenação, tanto para trabalhadores, quanto para empregadores. Para ambos, os custos da ação coordenada para promover causas comuns têm sido elevados e, por isso, os sindicatos e associações de empresários associaram-se apenas para finalidades muito específicas, que não podem ser alcançadas por atores coletivos singulares. Por assim dizer, a organização centralizada só é acionada quando ela distribui os custos de mobilização, como é o caso da representação política dos segmentos trabalhadores. Essa especificidade, como se verá, é um dado relevante para compreender os padrões de relação entre Estado e sindicatos e as respostas que aquele oferece aos problemas encontrados na economia, na forma de regulação das relações de trabalho.

Considerando que a diversidade econômica dividia os trabalhadores em demandas setoriais mais estreitas, outro fator teve de uni-los. Esse fator, como se analisará a seguir, foi a experiência comum sob um ambiente legal repressivo, um sistema político excludente e o agravamento das condições de vida sob situações econômicas desfavoráveis. Como 
todos os trabalhadores enfrentavam essas mesmas condições, elas desempenhavam o papel de união necessário para o enfrentamento de sua posição (MARKS, 1989, p. 53).

\subsubsection{A proibição das associações - a repressão como fator de união}

Há um certo consenso na literatura a respeito da importância do período histórico que se prolonga de 1790, com o início da Revolução Francesa, até 1830, com o fim das Guerras Napoleônicas e o Concerto Europeu (THOMPSON, 1966; MARKS, 1989; REID, 2005). Nesse período, a conjunção da repressão política e legal com a super-exploração conduziu à formação de uma consciência de classe e, como decorrência lógica, à difusão e ao fortalecimento das associações sindicais. O impedimento da expressão pública e legal de seu descontentamento teria conduzido os trabalhadores a unir-se para lutar, por um lado, pelo reconhecimento de seu papel social e o direito de interferir nos rumos da política, e por outro, pela liberdade de associar-se e agir em defesa de seus interesses profissionais.

Esse foi o período da Revolução Francesa e de seus ecos em todo o Continente Europeu, além das guerras contra a causa revolucionária e, mais tarde, contra as campanhas de Napoleão. Politicamente, o período foi marcado pelo conservadorismo e repressão, justificados pelo risco de invasão estrangeira e de ameaça à ordem constituída por meio da contaminação pelos valores e ideais revolucionários. Até a reforma política de 1832, a nobreza e a aristocracia britânicas tinham controle absoluto sobre o Parlamento que, no período em questão, formou uma sucessão de governos Conservadores. Mas as guerras e os termos de conspirações intensificaram a repressão praticada pelas autoridades governamentais. Em 1794, o Habeas Corpus Act foi suspenso, após um período em que proliferavam acusações de conspiração contra o Rei e ventilação de idéias revolucionárias. Sob esse pretexto, associações são fechadas, suas publicações destruídas e seus líderes presos (THOMPSON, 1966, p. 132).

Economicamente, o período é igualmente drástico, com flutuações constantes decorrentes dos esforços de mobilização e desmobilização militar, além das dificuldades de manter o fluxo comercial com outras nações. Por um lado, foi um período de custos de vida elevados. Durante as Guerras Napolêonicas, isso se deveu à escassez resultante do bloqueio imposto à Grã-Bretanha. Quando os conflitos cessaram, as Corn Laws, leis protecionistas dos cereais, elevaram o custo dos alimentos. Por outro lado, foi um período 
de salários reduzidos. Tanto a mobilização militar, quanto a desmobilização tiveram esse efeito. No primeiro caso, os salários eram mantidos em níveis mínimos por meio de controle legislativo, embora a oferta de mão-de-obra fosse menor. No segundo caso, o controle não era necessário, pois a oferta aumentou consideravelmente, criando um exército de reserva que mantinha os salários baixos. Esse quadro era complementado, ainda, pelas condições degradantes do trabalho industrial, pelo rígido controle imposto aos trabalhadores de setores essenciais aos esforços de guerra e pela retração econômica que se seguiu a ela (THOMPSON, 1966; REID, 2005, pp. 60-1).

Se a repressão política e a crise econômica já bastavam para animar o fervor jacobino em alguns setores da população britânica (THOMPSON, 1966), os trabalhadores tinham ainda mais razões para organizar uma reação. Além dessas questões, estavam sujeitos a uma legislação que sancionava sua sujeição aos empresários e limitava a ação que poderia subverter essa condição, estipulando sanções criminais. Ao final do século XVIII, as relações de trabalho permaneciam reguladas pelo Statute of Artificers, ao qual se somava a legislação esparsa, produzida para setores específicos, com regulações sobre salários e condições de trabalho, além de alguns atos legislativos que proibiam a associação de trabalhadores. Em plena industrialização, a legislação sujeitava o trabalhador às obrigações impostas pelo seu mestre em uma relação duradoura que, na maioria dos casos, só podia ser terminada pelo último. O contrato de trabalho correspondia, desse modo, a uma figura transicional entre um contrato relativo ao status e um contrato determinado por sua finalidade (WEBER, 2004, p. 536). Ainda que o contrato fosse guiado por uma finalidade específica, a venda da força de trabalho por um salário, era uma relação duradoura que transformava a classificação das partes nela envolvidas: por meio do contrato, o comprador do trabalho transformava-se permanentemente em mestre e o vendedor, em subordinado. Sequer o direito e sua linguagem tratavam as partes contratuais como iguais.

Essa assimetria de poder juridicamente sancionada torna-se evidente aos trabalhadores à medida que o seu oposto, a igualdade jurídica, era proclamada no Continente Europeu. Juntamente com a repressão política e as condições econômicas, esse marco legal desigual e punitivo promovia a união dos trabalhadores em torno da luta pela dignidade que lhe era devida como homens livres. Havia um sentimento comum de ressentimento responsável pela eclosão de numerosas manifestações, movimentos e revoltas. O período das guerras foi de incomparável agitação política e social, com 
manifestações de grande vulto (Peterloo, $1819^{73}$ ), a proliferação da atividade sindical e dos movimentos radicais, o ludismo, no início da década de 1810, o owenismo, o movimento pela legislação de 10 horas e, por fim, o cartismo (THOMPSON, 1966, p. 191). Sob esse contexto, trabalhadores superaram suas divisões, observando compartilharem uma mesma condição política, econômica e legal, e passaram a organizar-se conjuntamente para alterar o estado de coisas.

O ápice desse estado de insatisfação coletiva com a repressão legal dá-se na transição para o século XIX, com a edição de "um ato para prevenir combinações ilegais de trabalhadores”, que passaria a ser conhecido como Combination Act (Atos de combinação). A lei foi motivada pelo fortalecimento das associações de trabalhadores e a crescente agitação promovida pelo descontentamento com as agruras da guerra, considerada impatriótica pelo governo. Como a agitação afetava setores vitais aos esforços da guerra revolucionária, foi sugerido que manifestações dos trabalhadores organizados estavam associadas a conspirações revolucionárias na Grã-Bretanha. Em decorrência, considerava-se necessário eliminar as associações de trabalhadores para evitar a contaminação da população britânica pelos ideais revolucionários franceses (THOMPSON, 1966; REID, 2005, p. 73)

O Combination Act representou uma condenação das associações de trabalhadores à ilegalidade durante um quarto de século, em um contexto já extremado de repressão política. Os Combination Acts não foram as primeiras peças legislativas proibindo a associação ou manifestação de trabalhadores organizados. Foram, também, apenas mais um exemplo de uma legislação que estatuía uma clara desigualdade jurídica entre empregadores e empregados. Já havia suficientes provisões legais antes dos Acts que tornavam qualquer forma de ação coletiva dos trabalhadores sujeita à punição criminal, quer por representar uma violação de contrato por deixar o trabalho sem terminar, sob o Statute of Artificers, quer porque o Common Law, isto é, o corpo de precedentes judiciais, considerava que tais ações correspondiam a conspirações (THOMPSON, 1966, p. 504). Ademais, leis específicas de combinação proibindo a associação dos trabalhadores já existiam em diversos setores em que os trabalhadores eram mais organizados (REID, 2005, p. 15). A nova lei foi, aliás, modelada em uma dessas leis, válida para os trabalhadores da indústria de papel - como modelo (idem, p. 73).

\footnotetext{
${ }^{73}$ O Massacre de Peterloo teve lugar em Manchester em 1819 e foi o resultado de um ataque da cavalaria contra a multidão que se reunira para demandar a reforma na representação parlamentar. 15 pessoas foram mortas e mais de 500 feridas no confronto.
} 
Desse modo, o Combination Act de 1799 apenas consolidava uma proibição que já se estendia aos setores mais ativos dos trabalhadores e generalizava-a. Mantendo o espírito penal da legislação relativa à associação sindical e às relações de trabalho existente, o Act cominava a associação para fins de promoção de interesses próprios e demanda de salários maiores com uma pena de três meses de prisão ou dois meses de trabalhos forçados. Diante da comoção provocada em um contexto de elevada tensão política, um novo Combination Act foi editado no ano seguinte, procurando conferir uma aparência de igualdade no tratamento de todas as associações baseadas em interesses econômicos, fossem elas de empresários ou de trabalhadores. Ainda assim, a pena cominada aos mestres que se engajassem em associações para reduzir salários era uma multa de vinte libras (REID, 2005, p. 74). Sua principal inovação, em relação à legislação precedente, foi a simplificação procedimental: as leis criavam um procedimento sumário para a condenação, presidido por um magistrado, de acordo com o Act de 1799, e dois magistrados, de acordo com o Act de 1800 (THOMPSON, 1966, p. 504; REID, 2005, p. 73).

Nesse sentido, os Combination Acts constituíram uma forma de racionalização e de simplificação da aplicação de toda a legislação anti-associação sindical que existia até o momento, algo que interessava tanto aos empresários, preocupados com o incremento da organização dos trabalhadores, quanto ao governo Conservador, preocupado com as conspirações políticas e a possível transferência dos valores revolucionários continentais. Com efeito, sua aprovação legislativa foi o resultado de uma associação entre esses dois grupos, preocupados com suas respectivas conspirações, que se repetiria anos mais tarde quando da revogação de leis que regulavam salários e condições da indústria em setores específicos e o dispositivo do Statute of Artificers que restringia o aprendizado. O Governo angariava, assim a lealdade da classe capitalista ao regime, aos esforços de guerra e sua anuência com a repressão praticada contra os movimentos radicais de matriz jacobina. $\mathrm{O}$ empresariado, por sua vez, ampliava sua liberdade de contratar com uma massa de trabalhadores, aos quais a defesa coletiva dos interesses era interditada (THOMPSON, 1966, p. 197-8).

Ainda assim, nem todos os empresários seduziram-se pelos Acts of Combination e a voracidade com que podiam desarticular o crescente movimento dos trabalhadores. A pesquisa histórica impecável de Thompson (1966, pp. 505-7) e Reid (2005, pp. 74-5) demonstra que ele não foi tão empregado quanto se podia esperar e aponta algumas razões. Em primeiro lugar, a lei conferia aos empregadores o ônus de apresentar a denúncia e 
processar as associações de trabalhadores. Esse ônus representava custos significativos, com os quais nenhum empresário queria arcar sozinho. Contudo, a competição entre empresários do mesmo setor - sujeitos, portanto, às mesmas associações de trabalhadores era muito grande para permitir que organizassem uma reação coordenada. O processo contra as associações envolvia também dificuldades consideráveis. Era necessário obter duas testemunhas que atestassem a existência das associações sindicais entre os trabalhadores. Em segundo lugar, se os empregadores conseguissem demonstrar essa associação, perderiam seus melhores trabalhadores, que seriam condenados a três meses de trabalhos forçados. Mostrava-se mais efetivo, portanto, quando desejavam reprimir as associações de trabalhadores, recorrer aos outros instrumentos legais disponíveis: o Statute of Artificers, que penalizava os trabalhadores por deixar seu trabalho sem finalizar ou as provisões do Common Law sobre as conspirações criminais. O primeiro documento conferia às autoridades o ônus de processar os implicados, permitia que fossem punidos apenas os líderes das organizações, sem comprometer a força de trabalho da empresa, e que fossem apreendidos fundos e publicações, prevenindo futuros problemas. O entendimento jurisprudencial relativo às conspirações criminais, por sua vez, tinha a vantagem de dispensar a necessidade de testemunhas quando greves estivessem em andamento, julgando que o movimento em si era prova da associação de trabalhadores.

O Combination Act tampouco constituiu a mais rigorosa proibição contra a associação de trabalhadores. O que a lei proibiu eficazmente foram as manifestações públicas, incluindo as greves. Entretanto, a lei não revogou dispositivos anteriores, como os do Statute of Artificers que permitiam aos trabalhadores levar a juízes de paz reclamações sobre salários, que caberia a eles arbitrar. Essa prerrogativa era somada ao direito dos trabalhadores de, em certas ocasiões, encaminhar petições ao Parlamento. Ambos exigiam um grau de organização dos trabalhadores, ao menos para selecionar representantes, que era legalmente tolerada. Além disso, muitos sindicatos constituíam-se naquele período como sociedades de benefício mútuo ou clubes reunidos em tavernas, aos quais bastou adotar uma postura mais discreta para que pudessem continuar a reunir-se e discutir pautas comuns dos trabalhadores (THOMPSON, 1966, pp. 181, 505).

Ainda que não fosse mais rigoroso ou eficiente do que a legislação pretérita para coibir o direito de ação coletiva dos trabalhadores, o impacto que causou nas consciências dos trabalhadores foi intenso. As leis surgiam em clara contradição com o espírito geral que se espalhava pela população britânica, como um contra-senso revolucionário, que ia de 
encontro ao crescimento da consciência de classe e aspirações mais amplas de liberdade, que se espalhavam pela população britânica, além do incremento do número de trabalhadores industriais e do grau de sua organização. Somavam-se a intensificação da exploração no trabalho, a deterioração das condições de vida pelas Guerras Napolêonicas e a opressão política praticada para conter as conspirações revolucionárias em uma só sensação profunda de ressentimento com o regime que conduziu os trabalhadores a radicalizarem sua luta (THOMPSON, 1966, pp. 198-9; REID, 2005, p. 76).

Longe de desaparecer, os sindicatos e clubes de trabalhadores passaram a operar na clandestinidade e adaptaram-se a esse quadro (THOMPSON, 1966, p. 503). Operando contra o marco legal vigente e as autoridades políticas, a hostilidade em relação a ambos era intrínseca. Por esse forte sentimento de injustiça, a legislação teve o efeito adverso do pretendido: durante os vinte e cinco anos em que esteve vigente, o sindicalismo não apenas continuou vivo, como também registrou grandes avanços. Prosperou nos setores dos ofícios tradicionais, mas também se difundiu em novos ofícios, especialmente os que surgiam com o crescimento industrial (THOMPSON, 1966, pp. 503-4). Considerando a pouca disposição de alguns empregadores em fazer uso da legislação e o interesse de estabelecer relações mais cordiais com seus funcionários, houve até mesmo negociações, acordos e arbitragens sobre salários e condições de trabalho no período (REID, 2005, p. 56). Quando, aliás, o Parlamento formou um Comitê para rever as desigualdades e inconsistências da legislação proibindo a associação sindical, muitos empresários que ofereceram seus depoimentos expressaram a opinião de que a lei era inócua, injusta e servia somente para agravar as relações entre empregadores e empregados (idem, 76).

Mas o marco legal e a repressão política impediam essas associações de se firmar como interlocutores legítimos na negociação e regulação das condições de trabalho. A via da luta sindical estava interditada e era necessário desobstruí-la, para o que seria necessário promover reformas políticas e legislativas. O desejo de reformar uma legislação injusta e punitiva uniu diferentes grupos de trabalhadores, antes divididos por demandas específicas (MARKS, 1989, pp. 51, 53). Organizados em associações representativas militantes, preocupadas com a promoção dos interesses de toda a classe, os trabalhadores decidem tomar um curso de ação política. Haviam desenvolvido uma consciência própria sobre a sua contribuição positiva para a sociedade e pretendiam ser reconhecidos como uma força social. Entretanto, seus interesses eram ignorados por um sistema político considerado elitista, parasitário e corrupto, e por um marco legal que sancionava a sua inferioridade de 
direitos em relação a seus mestres e punia criminalmente a sua organização independente, direito que julgavam natural do homem livre. Para alterar essa condição, julgavam necessário obter voz e direitos políticos, sem os quais seus interesses continuariam a ser ignorados pelo sistema político. A conquista do sufrágio universal masculino tornava-se para os trabalhadores do século XIX o remédio fundamental para todos seus problemas (REID, 2005, pp. 65- 69).

Esse sentimento colocou, lado a lado, associações sindicais e grupos reformistas (THOMPSON, 1966, p. 500) e, a partir da terceira década do século XIX, os trabalhadores assumiram consistentemente duas frentes de batalhas. Juntamente com a luta pela liberdade de associação e negociação, perseguiram um programa de reforma política que visava à expansão do sufrágio. Para operacionalizar esses planos, os sindicatos passam, então, a constituir organismos de coordenação de esforços, tanto na arena política e de pressão parlamentar, quanto na luta por melhores condições de trabalho. Esses organismos podiam fornecer assistência e conselhos a trabalhadores menos organizados, promover campanhas legislativas para regular as condições de trabalho de grupos mais fracos e patrocinar a campanha de candidatos alinhados com os interesses trabalhistas (REID, 2005, pp. 105-6).

Dois caminhos distintos de luta abriam-se para os trabalhadores nesse período. De um lado, havia a proposta de radicais jacobinos de uma luta com o emprego da força física, inspirada pelo método revolucionário francês. De outro, organizações de trabalhadores criadas para a específica finalidade de promover reformas políticas defendiam o uso de métodos pacíficos de pressão política, baseados na "força moral" das massas e de suas manifestações não violentas (REID, 2005, p. 143). Thompson ocupa-se longamente em sua pesquisa histórica de demonstrar a força do movimento jacobino britânico nessas décadas de intensa agitação na Europa. A despeito da dura repressão do governo a ações que considerava subversivas, ousadas organizações jacobinas continuavam operando na clandestinidade. Contudo, o movimento de caráter mais radical não obteve muito êxito e conquistou limitado apoio social. A maioria dos trabalhadores e suas organizações eram reticentes em empregar a violência como meio de luta.

Reid (2005, p. 58) demonstra que, a despeito da notoriedade de alguns casos célebres de ação violenta dos trabalhadores, práticas como a destruição patrimonial, incluindo a quebra de máquinas, e formas violentas e coercitivas de manifestação, foram raras. A mais célebre onda de radicalismo dos trabalhadores na indústria foi, sem dúvida, o ludismo, denominação derivada do personagem Ned Ludd, ou General Ludd, pretenso 
autor criado pelos ludistas para dirigir anonimamente ameaçadoras cartas aos empresários. O ludismo não constituiu um movimento único, mas levantes simultâneos de sabotagem industrial em várias partes da Grã-Bretanha em 1811 e 1812 com táticas comuns e um formidável nível de coordenação. O movimento não foi bem sucedido em sua revolta contra o governo e as guerras por ele praticadas, nem foi atendido em suas demandas de melhores salários e condições de trabalho (idem, p. 60).

Ao condenar à ilegalidade as associações trabalhistas, a legislação contribuiu para aproximar trabalhadores e radicais jacobinos (THOMPSON, 1966, p. 500). Ainda assim, os trabalhadores mais radicais não se identificavam e sentiam-se até intimidados pelos jacobinos egressos da burguesia. Por essa razão, mesmo quando desejavam empregar a força física, os trabalhadores acabaram por desenvolver formas próprias de ação.

Em suma, os maiores legados do jacobinismo não foram o êxito de sua ação ou os métodos propostos, mas os valores liberais que transmitiu aos demais movimentos populares e o incentivo à organização para reforma política (THOMPSON, 1966, p. 181). Nas primeiras décadas de século XIX houve um amplo debate sobre noções como independência pessoal, patriotismo e direitos naturais do homem livre, que recebeu considerável influência dos radicais. Contra o patriotismo invocado pelo governo para justificar medidas repressivas de proteção da ordem e da integridade territorial, os liberais proclamavam o patriotismo de sua luta de resgate da nação contra o conservadorismo corrupto.

Ao longo do século XIX, o liberalismo das idéias de Paine e Locke passou a dominar as mentes e corações do operariado britânico, (THOMPSON, 1966). A luta dos sindicatos no século XIX pela liberdade de associação e pela reforma política assumiram gradativamente uma retórica liberal, empregando noções como a de independência pessoal dos trabalhadores, de direitos políticos e de liberdade para negociar os termos de seu contrato de trabalho em condições de igualdade e de liberdade de associação (REID, 2005, p. 67).

Todos os males da classe trabalhadora eram associados à ausência de poder político. Na época, o voto era restrito a homens adultos com propriedade e a distribuição de cadeiras no Parlamento definida por critérios antiquados, que não consideravam o aumento da população em condados industriais. Como não tinham voz para interferir na produção de políticas e leis, eram dependentes dos desígnios de uma aristocracia que não reconhecia seus direitos de liberdade de ação e contratação. A despeito do importante papel 
social que exerciam para o progresso da nação britânica, era-lhes interditada a expressão de seus interesses. Se quisessem modificar o quadro legal e melhorar sua participação na distribuição das riquezas sociais, acreditavam, deveriam conquistar o poder de eleger representantes alinhados com seus interesses (REID, 2005, p. 69).

A luta de Francis Place, cuja citação abre o capítulo, de alguns parlamentares liberais e dos movimentos populares pela revogação do Combination Act constituem um episódio relevante para compreender quais os rumos da ação política iniciada pelos trabalhadores e verificar sua preferência pelos valores liberais. A revogação do Combination Act em 1824 constituiu a primeira vitória dos trabalhadores desde sua entrada na esfera política. A nova lei de 1824 (Combination Laws Repeal Act), conquistada pela mobilização das associações operárias, com o apoio dos liberais no Parlamento, revogou as leis de combinação existentes (trinta e cinco, no total) e, explicitamente, impediu que o Judiciário considerasse a ação sindical uma conspiração perante o Common Law (THOMPSON, 1966, p. 514; REID, 2005, p. 77).

A revogação das leis foi defendida sob as bases da proclamação da liberdade do trabalho para agir e negociar suas condições de trabalho. No debate público apelava-se para a idéia de que em uma sociedade justa os homens devem ser livres e independentes, inclusive para organizar-se, mas Place também invocava a racionalidade das leis de mercado que estariam sendo deturpadas pela proibição da associação sindical. A liberdade de negociação e contratação coletiva, acreditava Place, era uma forma mais racional e amigável de conduzir as relações de trabalho, adequada à realidade de mercado. Somente em condições de plena liberdade as leis da oferta e da procura poderiam regular o preço do trabalho sem interferências externas (THOMPSON, 1966, p. 518). Ademais, argumentava, a restrição legal criaria um desnecessário antagonismo entre empresários e seus trabalhadores que potencializava os conflitos e as greves (REID, 2005, p. 75). A posição de Place refletia, de acordo com Steinfeld, de: "um compromisso com uma visão particular de laissez-faire, uma visão que eles acreditavam iria ajudar a restaurar a harmonia às relações de trabalho” (2001, p. 95. Traduz-se ${ }^{74}$ ). De fato, essa visão, ainda em seu estado nascente, será o pilar do voluntarismo e, assim, de uma atuação mais sistemática do Estado na regulação dos conflitos de classe no futuro.

A revogação dos Combination Acts representou uma vitória limitada e efêmera, apenas a primeira de muitas lutas para eliminar a legislação que restringia a ação sindical.

\footnotetext{
${ }^{74}$ No original: “[...] a commitment to a particular vision of laissez-faire, a vision they believed would help to restore harmony to labor relations” (STEINFELD, 2001, p. 95).
} 
A revogação da proibição das associações em um contexto econômico muito desfavorável aos trabalhadores levou, em 1824, a uma onda de agitação, incluindo greves e demandas que haviam sido contidas por um quarto de século. O Parlamento, sob as ordens de Lord Liverpool, logo se dispôs a promover uma revisão legislativa, em 1825, que tinha o claro intuito de restaurar a ordem anterior. Contudo, a proposta de retornar ao estado anterior apenas aguçou “[...] a tempestade de protestos, petições, reuniões e representações de cada ofício” (THOMPSON, 1966, p. 520. Traduz-se ${ }^{75}$ ). Organizações de pressão no parlamento conseguiram assegurar uma legislação menos prejudicial do que os Combination Acts, mas menos benéfica que o Combination Laws Repeal Act. A lei de 1825 manteve o dispositivo que isentava os trabalhadores de acusações de conspiração por juízes com base no Common Law e a permissão à greve, desde que as ações dos trabalhadores fossem restritas a pretensões salariais e relativas à extensão da jornada de trabalho (REID, 2005, p. 77). A legislação conseguia, desse modo, restringir o escopo da negociação a temas de restrito alcance político. No entanto, essa não foi a principal limitação criada às associações sindicais por essa lei, mas sim a inclusão da proibição do emprego de “ameaças, intimidações, molestamento e obstrução” (MARKS, 1989, p. 64. Traduz-se ${ }^{76}$ ). O uso de expressões vagas, como “molestamento” e “obstrução”, permitiu ao Judiciário construir interpretações ampliativas, transformando praticamente todas as ações de reivindicação dos trabalhadores em formas de molestamento ou obstrução do trabalho. Essas expressões foram empregadas, sobretudo, para proibir as greves, consideradas uma forma de obstrução do trabalho.

Mesmo que a revogação dos Combination Acts houvesse sido mantida em sua integridade, permanecia em vigor, como já analisado, uma série de outros dispositivos que penalizavam a ação sindical e instituíam uma relação desigual entre trabalhadores e seus empregadores. A eles veio se somar, um ano antes da revogação dos Combination Acts, em 1823, outra peça legislativa que contrariava os espíritos de liberdade individual e igualdade jurídica, predominantes na população britânica. Trata-se do Master and Servants Act (Lei do Mestre e dos Servos). A lei buscava regular de modo mais abrangente as relações estabelecidas entre empregadores e empregados, especialmente com vistas ao trabalho que era exercido nas oficinas industriais, atualizando alguns dispositivos já encontrados no

\footnotetext{
75 No original: “[...] the storm of protests, petitions, meetings, and deputations from every trade" (THOMPSON, 1966, p. 520).

76 No original: “threats, intimidation, molestation and obstruction” (MARKS, 1989, p. 64). Essa era exatamente a redação empregada pela lei.
} 
Statute of Artificers. O Master and Servants Act também estabelecia sanções criminais pelo descumprimento do contrato pelo trabalhador, tratado como servo pela lei. O descumprimento, mais uma vez, podia ser simplesmente uma troca de emprego, já que o trabalhador não tinha liberdade para terminar sua relação com o patrão sem a autorização desse e sem que houvesse terminado seu serviço (STEINFELD, 2001, p. 97).

Do ponto de vista de sua justificação, mas também do momento em que foi promulgada, a nova legislação era uma aberração. Em meio ao movimento pela liberdade de associação e pelo reconhecimento dos trabalhadores como uma força social com iguais direitos formais, a lei reforçava a sujeição dos trabalhadores, empregando uma linguagem obsoleta que fazia referência à relação feudal entre servo e senhor. Embora criada com o argumento liberal de que nada pode limitar a livre iniciativa do empresário e sua liberdade de gerir seu negócio, ela impunha graves limitações à livre negociação entre as partes contratuais. O empregado não tinha nenhuma liberdade para decidir como dispor de seu trabalho e sua mobilidade era integralmente controlada pelo patrão. Era, portanto, um liberalismo de via única. A lei reforçava a prerrogativa do empresário de gerir seu negócio sem intervenções, mas extinguia qualquer liberdade do trabalhador, que devia lealdade e obediência cega às ordens patronais. Novamente, as violações contratuais do empregado recebiam tratamento penal. Qualquer servo que descumprisse o seu contrato, deixando seu mestre, por exemplo, podia ser preso por três meses. Os mestres, por sua vez, recebiam apenas uma multa pelo descumprimento contratual. A ação coletiva também era limitada pela lei, que considerava quebra contratual toda ação restritiva ao comércio. Se a lei de 1825 deixava dúvidas sobre a legalidade da greve e outras ações que contemplassem a interrupção da produção ou o abandono do posto de trabalho, o Master and Servant Act oferecia aos juízes desejosos de reprimir a ação sindical dois valiosos fundamentos jurídicos: as proibições da "restrição ao comércio" e do “abandono do trabalho" (STEINFELD, 2001, p. 93; REID, 2005, p. 154).

Em decorrência da manutenção desse tratamento desigual e punitivo, as organizações de coordenação de sindicatos continuavam a pressionar por uma reforma política. Essa luta foi marcada por seu lento avanço e vitórias paulatinas, intercaladas com alguns reveses. No início de 1830, diante da comoção causada pela derrubada da monarquia na França, o governo liberal recém-formado introduziu uma reforma ampliando o sufrágio e a representação parlamentar dos distritos fabris. A reforma foi, porém, rejeitada pela Câmara dos Lordes, à época ainda com poder de veto. Grandes 
manifestações com ampla participação dos sindicatos foram organizadas em resposta ao que consideravam a obstrução de uma classe parasitária - a nobreza - aos direitos do homem livre ${ }^{77}$. A reforma foi finalmente aprovada em 1832, mas foi acompanhada de medidas repressivas para desmobilizar a organização popular que havia se formado em torno da reforma e restaurar a ordem, além da edição de uma nova Poor Law em 1834, reforçando ironicamente as noções de dependência e incapacidade dos mais pobres.

A desilusão com a tímida reforma de 1832, alimentou mais uma vez a mobilização popular. Nessa ocasião, amplos setores populares organizam-se em torno da adoção da Carta do Povo, um documento de reivindicações com seis pontos de reforma política: “parlamentos anuais, distritos eleitorais com igual peso, sufrágio universal masculino, voto por cédulas, a abolição de qualificações de propriedade para candidatos e a remuneração dos Membros do Parlamento” (REID, 2005, p. 139. Traduz-se ${ }^{78}$ ). O cartismo, como ficou conhecido, pretendia conquistar a igualdade dos direitos políticos promovendo grandes manifestações pacíficas que emergiram em ondas. Fomentado por trabalhadores, indicava a maciça entrada dos trabalhadores na arena política, a centralidade da reforma política em sua estratégia e a preferência por formas de ação que apelassem para a força moral das massas, evitando-se o uso da violência (idem, p. 143).

Em 1867, na última onda de manifestações cartistas, uma reforma política limitada é promovida por Disraeli. A reforma concedia o sufrágio a aproximadamente $30 \%$ dos trabalhadores do sexo masculino. Mesmo com essa tímida expansão, os trabalhadores obtiveram meios de influenciar políticas e eleger candidatos alinhados a seus interesses, especialmente entre os membros mais radicais do Partido Liberal (REID, 2005, p. 148). Desde a primeira metade do século os sindicatos vinham reunindo-se para formar grupos de pressão política. Coordenavam suas atividades para lograr reformas políticas que lhes permitissem agir em defesa de seus interesses. A primeira associação expressiva foi o London Trades Council, criada em 1859 por lideranças sindicais de setores artesanais da produção (idem, p. 144). Em 1868, por sua vez, duas organizações de expressiva importância para o movimento foram formadas: a Labour Representation League (Liga da Representação Trabalhista) e o Trades Union Congress (Congresso dos Sindicatos). A

\footnotetext{
${ }^{77}$ Nem todas as organizações sindicais apoiaram a reforma. Os setores mais radicais do movimento operário julgavam que a lei beneficiaria apenas a classe média e não alterava substancialmente o establishment (REID, 2005, p. 138).

${ }^{78}$ No original: "annual parliament, equal electoral districts, universal male suffrage, vote by ballot, the abolition of property qualifications for candidates, and the payment of MPs” (REID, 2005, p. 139).
} 
primeira tinha por objeto coordenar o apoio a candidatos do movimento sindical e ampliar a independência dos trabalhadores em relação ao Partido Liberal (idem, p. 145).

O Trades Union Congress (TUC) tornar-se-ia a única organização de cúpula do movimento sindical, coordenando a ação sindical em temas de interesse comum. Em suas origens, contudo, o TUC era uma sociedade em que sindicalistas podiam debater condições políticas, econômicas e sociais do trabalho em um congresso realizado anualmente (MARKS, 1989, p. 65). Sua finalidade era encontrar formas de pleitear o reconhecimento da classe trabalhadora na sociedade britânica vitoriana. Para tanto, desenvolvia estratégias de ação em pautas comuns do sindicalismo e pressionava políticos por reformas legislativas. O TUC não foi criado, portanto, para substituir os sindicatos em negociações coletivas sobre salários ou condições de trabalho, mas para coordenar uma resposta às ameaças do marco legal à ação sindical, isto é, para remover os obstáculos que impediam os sindicatos de perseguir suas estratégias próprias (MARKS, 1989, p. 51). Nunca assumiu posições de forma autônoma e continua, até os dias de hoje, dependente das resoluções dos sindicatos que o integram (idem, p. 65).

Em 1870, com a finalidade de fiscalizar a atuação do Parlamento e pressionar políticos por uma reforma da legislação trabalhista, o TUC formou um Comitê Parlamentar. Mais tarde, com a eleição de candidatos das fileiras sindicais, esse comitê tornou-se autônomo, formando juntamente com o International Labour Party, federação formada principalmente por organizações de trabalhadores do Norte da Inglaterra e Escócia, o Labour Representation Committee (Comitê de Representação Trabalhista), órgão parlamentar de apoio às causas dos trabalhadores que, em 1900, dará origem ao Labour Party.

Essa ampla mobilização política da classe trabalhadora conduziu a uma progressiva incorporação dos sindicatos à sociedade britânica no último quartel do século XIX. A despeito das leis desfavoráveis, os sindicatos passaram a ser vistos como organizações legítimas, que reuniam trabalhadores esforçados e respeitáveis, que apenas buscavam com meios pacíficos e legítimos sua independência e igualdade de direitos. Havia, certamente, manifestações violentas dos operários, mas eram elas obscurecidas por movimentos moderados de pressão política e melhoria das condições de trabalho.

Ademais, por meio de sua representação parlamentar, os trabalhadores haviam transformado a opinião dos demais políticos em seu favor, convencendo-os de sua respeitabilidade e da justiça de sua pretensão por um tratamento equânime perante a lei. 
Um compromisso de classes era, dessa forma, firmado ${ }^{79}$ : a elite política reconhecia os sindicatos como uma recompensa pelo abandono do radicalismo (HOWELL, 2005, p. 60). O relaxamento na aplicação das leis restritivas da ação coletiva, por sua vez, reforçava a rejeição a radicalismos e a moderação dos movimentos sindicais (GEARY, 1981). Assim, embora a repressão legal elevasse o custo de organização sindical, o amplo apoio social às suas demandas e a simpatia de setores do parlamento com sua causa criavam uma situação de tolerância e uma disposição para reforma do marco regulatório. Em um claro exemplo do chamado efeito do flanco radical proposto por McAdam, McCarthy e Zald (1996, p. 14), os sindicatos atraíam grande apoio da sociedade com suas propostas moderadas e ações pacíficas.

Todavia, a conquista de uma opinião parlamentar mais favorável à causa sindical não representava o fim os problemas de organização da ação sindical. Algumas leis atenuaram a proibição das associações e suas greves, mas um crescente ativismo judicial limitou as conquistas legislativas e restava, ainda, eliminar a vetusta legislação que regulava as relações de trabalho de modo desigual e punitivo. Em 1859, o Molestation of Workmen Act foi promulgado para esclarecer o sentido da expressão "molestamento" que era empregado como fundamento para proibir as greves de acordo com a lei de 1825. A lei expressamente permitiu o emprego de “formas 'pacíficas e razoáveis' de persuasão de outros trabalhadores durante uma disputa industrial” (REID, 2005, p. 150. Traduz-se ${ }^{80}$ ).

Na década seguinte, porém, uma série de decisões judiciais passaram a invocar outros fundamentos para proibir a ação dos sindicatos. Primeiro, consideraram as greves e as negociações relacionadas como uma ameaça de dano econômico ao empresário. Depois, passaram a empregar o conceito de "restrição do comércio" (restraint of trade) ${ }^{81}$. O Judiciário e o direito por ele produzido sob o regime de Common Law revelavam preferências ideológicas por um liberalismo individualista e um viés anti-trabalhador. Os juízes expressavam uma crença no indivíduo e em sua capacidade de assumir compromissos e agir sem as interferências, inclusive, de associações como sindicatos. Além disso, o receio com o declínio relativo da economia britânica desde o final do século

\footnotetext{
${ }^{79}$ Costuma-se denominar esse compromisso de gladstoniano, em alusão ao líder liberal que ocupou longamente o cargo de Primeiro-Ministro no século XIX e sob o governo do qual se firmou.

${ }^{80}$ No original: "“peacable and reasonable' forms of persuasion of other workmen during industrial dispute” (REID, 2005, p. 150).

${ }^{81}$ Originalmente, o instituto era empregado na legislação comercial para impedir a concorrência por um vendedor de um negócio (REID, 2005, p. 150).
} 
XIX e a associação desse fenômeno à força do trabalho organizado conduziam o Judiciário a assumir posições favoráveis aos empresários (WEDDERBURN, 1995, p. 31).

A despeito do crescente reconhecimento público, portanto, a situação dos sindicatos era ainda juridicamente precária. Tendo de enfrentar um Judiciário hostil, além de leis que estabeleciam um tratamento desigual aos trabalhadores, a completude de sua luta pela igualdade jurídica e a liberdade de ação exigia, ainda, uma reforma no marco regulatório que, a um só tempo, abolisse a legislação antiga e impedisse o Judiciário de interferir no funcionamento dos sindicatos. A oportunidade para tanto surgiu, ironicamente, quando trabalhadores organizaram uma violenta manifestação em Sheffield, que incluiu atos de sabotagem e até a destruição da casa de um colega que se recusava a colaborar (REID, 2005, p. 150). A reação dos sindicatos foi rápida e muito perspicaz: para evitar que esse fato isolado contaminasse a percepção coletiva sobre a ação pacífica dos sindicatos na sociedade britânica, apoiaram os empresários afetados e as autoridades locais em sua demanda pelo estabelecimento de uma investigação governamental. As preocupações do Parlamento com o crescente poder dos sindicatos transformaram essa comissão de investigação em uma ampla Comissão Real para rever o status legal dos sindicatos, em 1867 (idem, p. 151). Alguns sindicatos, decididos a aproveitar a oportunidade para conquistar um marco legal mais benéfico, organizaram uma resposta conjunta e solicitaram a nomeação de dois membros do movimento sindical para a Comissão. Apenas um membro foi autorizado a integrar a Comissão, mas por meio dele os sindicatos puderam expressar o seu ponto de vista. Coordenaram uma resposta que descrevia as associações sindicais como organizações de auxílio mútuo entre trabalhadores e de encaminhamento pacífico de demandas exclusivamente sobre salários e jornadas de trabalho (idem, p. 152).

Persuadidos por essa imagem, a Comissão adotou uma visão em que os sindicatos eram considerados organizações pacíficas e a negociação coletiva por eles praticada um meio eficiente de regular as relações de trabalho e evitar conflitos. Contudo, os sindicatos obtiveram apenas a proteção de seus fundos de bem-estar, pois somente a minoria dos membros recomendou a proteção dos sindicatos da doutrina judicial da "restrição ao comércio” e das acusações de conspiração criminal (REID, 2005, p. 152).

Não obstante a limitada vitória, o relatório redigido pela minoria tornou-se um respeitável manifesto empregado pelo TUC para exigir reformas legislativas. Referendadas por dois membros de uma Comissão Real, as pretensões dos sindicatos ganhavam maior legitimidade e foram logo atendidas. Em 1871, dois atos modificaram a posição legal dos 
sindicatos: o Trade Unions Act (Lei dos Sindicatos) e o Criminal Law Amendment Act (Ato de Emenda do Direito Penal). O primeiro eliminou o conceito de "restrição ao comércio" e conferiu proteção aos fundos dos sindicatos, antes passíveis de seqüestro judicial. O segundo, alterou a definição legal do crime de ameaça ou intimidação, no qual era enquadrada a ação sindical. Determinou que apenas pessoas, e não bens ou o negócio, podiam ser alvo da prática criminosa, impedindo assim a acusação dos sindicatos por “ameaça de dano econômico”. Entretanto, ampliou as práticas consideradas intimidatórias com a inclusão das categorias "vigiar” e "assediar” (“watching” e "besetting”). Esses termos vagos permitiram, mais uma vez, que o Judiciário restringisse a ação sindical, proibindo uma série de táticas associadas aos atos de vigiar e assediar, como o piquete (HOWELL, 2005, p. 60; REID, 2005, p. 153).

Quatro anos depois, em 1875, os sindicatos conseguiram outra vitória com a edição do Employers and Workmen Act, revogando o Master and Servants Act ${ }^{82}$. O novo documento legal finalmente reconheceu a igualdade jurídica na relação de trabalho, ao menos formalmente. Na retórica, adotou uma linguagem apropriada para as relações de trabalho assalariadas, removendo os termos "servo" e “mestre”. Na prática, equiparou as sanções por descumprimento de contrato previstas para empregados e empregadores e substituiu as sanções penais pela responsabilização civil (REID, 2005, p. 155).

O contexto de relativa liberdade de ação permitiu o florescimento dos sindicatos não apenas nos setores da indústria artesanal, em que já estava cristalizado, mas também em setores em que os trabalhadores não estavam ainda organizados, como na indústria de produção em massa. O fortalecimento dos sindicatos na década de 1880 não foi, entretanto, bem recebido pela elite e pela imprensa tradicional. Havia crescentes receios de que o conflito industrial estaria promovendo o declínio econômico da Grã-Bretanha registrado no período, ou ao menos impedindo a sua recuperação. A perda da posição monopolista na produção mundial de bens e serviços financeiros, com a crescente concorrência de outras nações européias e dos Estados Unidos, conduzia o país a uma longa depressão e exigia respostas estatais. Uma dessas respostas foi a promoção do imperialismo, com a finalidade de escoar a produção a novos mercados e manter as taxas de lucro (HOBSBAWM, 1978).

Como se tornara comum associar a crise a comportamentos do poderoso movimento trabalhista que desorganizariam a produção, também se exigia do Estado uma intervenção para controlar o conflito industrial. Em 1894, uma nova Comissão Real sobre

${ }^{82}$ Embora abolida em 1875 na Grã-Bretanha, a lei continuou em vigor em outras regiões que pertenceram ao Império Britânico durante o século XX. 
Trabalho era organizada para investigar as causas do conflito industrial e, assim, subsidiar uma resposta estatal. A comissão contou com ampla colaboração de sindicalistas, expertos das relações de trabalho e empresários, que forneceram longos depoimentos e geraram um corpo de evidências que conferia ao relatório final grande robustez e a suas prescrições considerável legitimidade. Ao contrário do que se poderia esperar diante do contexto de relativa hostilidade do governo, o relatório afirmou a utilidade estratégica dos sindicatos para construir relações harmônicas de trabalho e as vantagens da negociação coletiva para regular de modo durável essas relações. Os sindicatos eram entendidos como veículos de organização dos trabalhadores, moderação de suas demandas e negociação de condições comuns a setores da economia. Além da definição de padrões setoriais, a negociação coletiva permitiria a criação de métodos voluntários de conciliação e arbitragem de conflitos, evitando o conflito aberto, e seria benéfico até mesmo para empresas, por limitar a concorrência predatória baseada em salários baixos. O relatório concluiu, ainda, que a legislação regulando as relações de trabalho deveria ser mínima, assegurando a disponibilidade de mecanismos de negociação e arbitragem de conflitos, mas não impondo a arbitragem compulsória, como desejava a minoria dos relatores (HOWELL, 2005, pp. 64-5).

Em suma, o relatório afirmava a convicção no voluntarismo coletivista como a melhor forma de regular as relações de trabalho e os conflitos que dela emergem e seu desprezo pela legislação, que não poderia remediar os problemas de conflito na indústria, por não representar a vontade dos atores (HOWELL, 2005, p. 65). Setenta anos após a proclamação de Place, o voluntarismo era reconhecido por um relatório oficial e proposto como princípio orientador da ação estatal na regulação do trabalho. Além de proclamar o voluntarismo, o reconhecimento do papel dos sindicatos na organização das relações de trabalho serviu para moldar as impressões e o discurso público sobre os sindicatos. Porque a Comissão conferiu argumentos de autoridade que demonstravam que, ao invés de produzir o conflito e o declínio econômico, os sindicatos eram uma peça-chave para solucionar esses problemas.

Enquanto se discutia como operacionalizar as prescrições da Comissão, em um debate que opôs setores do governo, o Judiciário, mais uma vez, respondeu de modo hostil à ação sindical. Inúmeras decisões judiciais limitaram a aplicação da nova legislação e criaram, sob o regime do Common Law, uma série de mecanismos de responsabilização civil dos sindicatos por atos que constituíam as formas fundamentais de protesto 
empregadas para pressionar empresários a acatar demandas (HOWELL, 2005, pp. 60-1). Os juízes argumentavam que, como líderes de poderosas organizações, membros da direção dos sindicatos deveriam ser responsabilizáveis civilmente, especialmente em casos de danos envolvendo terceiros não envolvidos na disputa (REID, 2005, p. 256). Aproveitando esse entendimento jurisprudencial, empresários recorreram freqüentemente ao Judiciário para evitar, por meio de medidas cautelares, conflitos industriais na última década do século XIX. Por sua vez, o uso do Judiciário como forma de controle da ação sindical intensificava a produção de entendimentos desfavoráveis aos trabalhadores.

Em meio ao ativismo judicial do final do século XIX, um caso destaca-se pelas suas conseqüências. Em agosto de 1900, os funcionários da Taff Vale Railway Company de Gales realizaram uma greve de protesto contra a relutância da empresa em reconhecer o sindicato e negociar melhores salários. O conflito terminou com um acordo em que se garantiam os empregos dos grevistas, mas não o reconhecimento do sindicato. Mesmo vitoriosa, a companhia decidiu processar o sindicato, alegando sua responsabilidade por danos e pleiteando o ressarcimento por meio de todos os fundos sindicais. O caso arrastouse por um ano e, ao final, a decisão reconhecendo a responsabilidade civil dos sindicatos e a possibilidade de utilização dos fundos para ressarcimento foi confirmada pela Câmara dos Lordes. A decisão condenou o sindicato dos ferroviários a pagar 23 mil libras esterlinas. A resposta imediata do TUC foi pressionar o governo para uma ampla investigação a respeito das implicações da responsabilização civil dos sindicatos que conduzisse a uma nova lei que protegesse os fundos de bem-estar dos sindicatos. $\mathrm{O}$ fracasso desse intento conduziu a uma mudança de estratégia. O TUC canalizou a comoção gerada pela responsabilização dos sindicatos em uma campanha para o aumento do número de parlamentares vinculados ao movimento sindical (REID, 2005, pp. 259-60). Receoso dos efeitos políticos, o governo organizou uma nova comissão real, mas sem a participação de sindicalistas. O relatório da comissão referendava as posições judiciais, mas sugeria que fossem os sindicatos transformados em associações legais e que o direito de greve fosse reconhecido.

Essas propostas não pareciam, ao trabalho organizado, uma solução. Afinal, avanços legislativos já haviam sido conquistados e, ao menos perante o marco legal, os sindicatos gozavam de uma relativa liberdade de ação. A Comissão Real sobre Trabalho de 1894 já havia reconhecido publicamente a função dos sindicatos na organização das relações de trabalho, na moderação dos trabalhadores e na solução dos conflitos. O maior 
obstáculo à ação era o Judiciário, com suas interpretações enviesadas dos textos legais e com a produção jurídica própria. Considerando o comportamento do Judiciário, nem mesmo o direito positivo à associação sindical poderia, acreditava o TUC, proteger a ação sindical dos juízes (HOWELL, 2005, p. 63).

A única forma de proteção seria o reconhecimento da imunidade dos sindicatos perante o direito produzido por juízes. Essa proteção seria conquistada com a edição do Trades Dispute Act, de 1906. O prestígio que os sindicatos gozavam perante o governo, em certa medida resultado das opiniões ventiladas no relatório da Comissão Real sobre Trabalho, serviu-lhes para conquistar uma proteção sui generis: não um direito de existir e agir, mas tão somente a garantia de não haver intervenções do direito em sua ação. Era um direito a não ser objeto da regulação jurídica.

A partir desse momento, a ação sindical pôde mover-se com limitados constrangimentos legais até 1979. Afastada a velha legislação que sujeitava o trabalhador aos ditames do empresário e responsabilizava criminalmente aqueles pelo descumprimento contratual, as partes puderam negociar as condições de trabalho e salários. Conseqüentemente, a negociação coletiva floresceu, como resultado da atuação dos sindicatos e das associações patronais e tornou-se o principal instrumento de regulação das relações de trabalho. O único empecilho que ainda afetará a ação sindical será o episódico ativismo judicial. Esse comportamento, aliás, manter-se-á praticamente inalterado até o final do século XX, conduzindo a uma constante disputa institucional entre Legislativo e Judiciário. Quase sempre que os magistrados ingleses - e também seus pares escoceses, a despeito da divisão funcional do Judiciário na Grã-Bretanha - eram instados a decidir sobre a aplicação de direitos relativos à organização e ação sindical, restringiam o alcance das garantias e ampliavam as limitações e obrigações. Em reação, novos atos legislativos eram editados, restringindo as interpretações que os juízes poderiam oferecer aos dispositivos.

A vitória nas duas frentes de batalha, pela reforma política e pelo direito de associação e ação sindicais, permitiu aos sindicatos concentrar seus esforços na negociação de condições de trabalho e salários, deixando as questões e demandas políticas para o Partido Trabalhista e o TUC. A despeito da significativa participação de sindicatos na composição do Partido Trabalhista e de seu peso nas decisões da organização partidária extra-parlamentar, os sindicatos e o partido desenvolveram atuações próprias e paralelas, 
com relativa independência. Não havia controle sindical sobre a atuação parlamentar do Partido Trabalhista, nem controle partidário sobre a atuação sindical.

A repressão praticada contra o sindicalismo britânico em seus primeiros momentos foi responsável por produzir novas formas de organização, fortalecer movimentos, criar órgãos de coordenação e pressão política e, sobretudo, os valores orientadores de sua relação com o Estado e o direito. Embora aumentasse os custos de organização, a repressão praticada pelas instituições e políticas estatais na regulação das relações de trabalho gerou grande solidariedade entre setores sociais e ressentimento, efeito previsto pela literatura para essas condições (TARROW, 1998, p. 24). Para lidar com os desafios de um marco legal desfavorável, os sindicatos criaram estruturas organizacionais mais complexas e com ampla cobertura nacional, com órgãos de assessoramento e pressão política e comitês executivos nacionais. Muitos sindicatos ganharam dimensões nacionais, ainda que permanecessem, por meio de escritórios locais, muito próximos dos trabalhadores.

A formação da classe operária e suas lutas em favor da reforma política e das liberdades de associação e ação legaram aos sindicatos britânicos uma profunda aversão pela regulação jurídica, a desconfiança na intervenção do Estado e o temor do controle judicial da ação coletiva. A leitura específica da condição histórica de repressão legal, exploração econômica e exclusão política dos trabalhadores, inspirada em um liberalismo igualmente específico, que conferia grande valor à ação coletiva, lega a preferência pelo laissez-faire coletivo. Parece natural que a decorrência de séculos de intervenções repressivas do Estado, nas formas administrativa, policial, judicial e legislativa, seja a defesa do voluntarismo, do abstencionismo estatal e das imunidades contra o controle judicial, deixando aos sindicatos espaço livre para regular coletivamente as relações de trabalho.

O raciocínio que conduz à defesa pelos sindicatos do voluntarismo coletivista é a regra de ouro do sindicalismo britânico até o final do século passado: o que o Estado não deu, ele não pode tirar; o que ele dá, inclusive na forma de legislação, pode ser retirado. Contudo, a reprodução dessa regra conduziu os sindicatos a negligenciar os recursos organizacionais que provinham do Estado ou os obstáculos para promover reformas legislativas. Esse erro de cálculo, como se verá, mostrou-se fatal quando os Conservadores, a partir de 1979, eliminaram os recursos com os quais os sindicatos contavam. Ainda assim, essa regra é importante para compreender as posturas assumidas pelo sindicalismo até o final do século passado, as políticas estatais de regulação das relações de trabalho e, 
em especial, o sentido específico da política de desregulação do mercado de trabalho, promovida pela Baronesa Thatcher.

A interpretação própria dos problemas de conflito industrial, inspirada pelos mesmos valores subjacentes à concepção do laissez-faire coletivo, condicionou respostas estatais que o reforçaram e reproduziram. Por assim dizer, essa concepção, fruto da experiência histórica do operariado britânico, moldou não apenas a ação sindical e suas preferências, mas também as políticas e instituições estatais de regulação do trabalho. O valor dos sindicatos para organizar os trabalhadores e regular conflitos e da negociação coletiva desimpedida tornaram-se consensuais e passaram a orientar as políticas e instituições, assim como a ação sindical. A partir de então, com esses valores como pressuposto, a regulação jurídica do trabalho foi mobilizada para responder aos desafios da economia britânica. O período que se estende da aprovação do Trades Dispute Act, de 1906, até o início da década de 1970, foi de limitada produção legislativa na área das relações de trabalho, mas nem por isso o Estado deixou de intervir e regular - inclusive juridicamente - nessas relações e na vida dos sindicatos. O Estado distribuiu recursos organizacionais aos sindicatos até 1979 e, posteriormente, enfraqueceu-os, para facilitar o controle gerencial sobre os processos produtivos e enfraquecer a resistência a alterações nos processos produtivos de bens e serviços.

\subsection{O sistema de laissez-faire coletivo}

\subsubsection{O período de negociação setorial ${ }^{83}$}

O final do século XIX corresponde a um momento de uma importante viragem na atuação estatal na regulação das relações de trabalho, ainda que mantendo e promovendo os princípios orientadores que haviam se desenvolvido no período anterior. Para Howell, o período assiste à emergência da primeira intervenção sistemática do Estado com pretensões de articular um modelo de regulação das relações do trabalho (2005, p. 46). Até então, o Estado havia disposto sobre a posição legal dos sindicatos e sobre as conseqüências de sua ação, sobre algumas condições de trabalho e buscara intervir nos conflitos e greves para

${ }^{83}$ Embora se valha de idéias e informações contidas em diversos autores, a fonte fundamental das informações e argumentos desta seção são de Howell (2005), que conduziu um estudo exaustivo sobre os sistemas de negociação coletiva incentivados pelo Estado Britânico no século XX. 
garantir a ordem e a propriedade. Após reconhecer o direito de associação e ação, pelo Trade Union Act, em 1871, e conferir imunidade às ações sindicais perante o Common Law no Trades Dispute Act, de 1906, contudo, a intervenção do Estado ganhou novas dimensões e objetivos.

Conforme afirmado, foram os desafios econômicos que a Grã-Bretanha teve de enfrentar que orientaram as intervenções regulatórias do Estado, imaginadas sempre como respostas a esses mesmos desafios. Desde o final do século XIX, com a Longa Depressão, a opinião pública britânica associava com freqüência condições de declínio econômico com a força dos sindicatos e sua capacidade de impor limites à produção (HOWELL, 2005, p. 60). Desse modo, a intervenção do Estado na forma de regulação das relações de trabalho e da ação sindical ganhava especial relevância na superação dos desafios econômicos. A transformação na intervenção estatal nas relações de trabalho é produto do reconhecimento dos efeitos econômicos dos conflitos emergentes dessas relações. A partir desse reconhecimento, o Estado assumiu a função de promover instituições que reduzissem os conflitos nas relações de trabalho e permitissem reestruturações necessárias nas empresas (idem, p. 47).

O primeiro desafio econômico a produzir uma resposta estatal na forma de um modelo de regulação das relações de trabalho estava relacionado justamente à Longa Depressão e ao declínio da indústria mais rudimentar, que ainda empregava métodos artesanais de produção, na transição entre os séculos XIX e XX. As dificuldades econômicas provocadas pelo incremento da competição nos mercados internacionais, com a emergência de novas potências industriais como a Alemanha e os Estados Unidos, acirraram a já elevada concorrência entre as pequenas firmas que conformavam essa indústria rudimentar. A estratégia adotada por essas pequenas empresas para fazer frente a essa condição era reduzir custos, oferecendo salários muito baixos e condições de trabalho precárias. A competição por salários menores gerava, por óbvio, insatisfação entre os trabalhadores, o que se traduziu em maior conflito industrial (HOWELL, 2005, pp. 49-51; REID, 2005, p. 165).

Além dos baixos salários, a elevação dos conflitos trabalhistas e das greves no final do século XIX tinha como causas as iniciativas empresarias de intensificar os controles sobre o trabalho e a resistência de alguns setores em reconhecer os sindicatos. Em razão da intensificação da concorrência, os empresários procuraram introduzir novas formas de controle sobre o trabalho para reduzir os custos e adotar métodos tradicionais de 
intensificação da exploração do trabalho o que encontrou forte resistência dos trabalhadores que, até então, detinham um relativo controle sobre os processos artesanais de produção (HOWELL, 2005, p. 53; HYMAN, 2005, p. 42). Além disso, pressionados pela concorrência, muitos empresários recusavam-se a reconhecer sindicatos, negociar condições de trabalho ou aceitar procedimentos para solução de disputas (HOWELL, 2005, p. 54).

Esse conjunto de fatores constituía os problemas que teriam de ser superados por um novo sistema de regulação das relações de trabalho, assim como o papel que o Estado teria de exercer para a sua implementação. Para permitir a racionalização das relações de trabalho, a solução dos conflitos trabalhistas e a recuperação econômica, a regulação teria de administrar a concorrência entre as empresas para impedir a depressão de salários, mas também garantir aos empresários sua prerrogativa de organizar os processos de trabalho sem a resistência dos sindicatos e, a esses, o reconhecimento pelas empresas, sem o qual, aliás, um sistema regulatório fundado na negociação coletiva não seria possível.

As indústrias mais rudimentares em crise não representavam a integridade do parque industrial britânico. Havia já empresas mais modernas, que adotavam processos de produção padronizada em massa e estavam voltadas para o mercado interno. A realidade econômica dessas indústrias mais dinâmicas era absolutamente diversa, já que além de serem menos dependentes dos mercados internacionais, dominavam os setores econômicos em que atuavam, nos quais o capital era muito concentrado em poucas empresas. Não apresentavam os problemas relacionados ao acirramento da competição. Ainda assim, a resposta estatal foi orientada para solucionar esses problemas e, assim, promover a recuperação das indústrias mais tradicionais. As razões para essa orientação eram claras: em primeiro lugar, eram as indústrias tradicionais que estavam em crise e enfrentavam maior grau de conflito industrial. Em segundo lugar, a intervenção estatal era mais relevante nessas indústrias já que, como havia muito mais atores concorrentes entre si do que nas cartelizadas indústrias de produção em massa, os problemas de coordenação eram mais graves e soluções negociadas improváveis. Por fim, a despeito de seu declínio, as indústrias rudimentares eram ainda muito relevantes para a economia do país, o que fazia com que a intensificação dos conflitos em seu interior fosse muito custosa (HOWELL, 2005, p. 52).

A realização da já comentada Comissão Real de 1894 foi justamente uma resposta aos receios pelos efeitos econômicos da intensificação da ação sindical e dos conflitos nas 
indústrias rudimentares nas últimas décadas do século XIX, relacionada aos baixos salários que as empresas ofereciam para baixar custos e enfrentar a concorrência. No ano anterior, pela primeira vez, o Estado interveio em uma greve, não para coibi-la, mas para promover um acordo entre sindicatos e empresários do setor carvoeiro (HOWELL, 2005, p. 47). A onda de greves e as dificuldades relacionadas à recuperação econômica criavam a opinião entre as elites e membros do governo de que novas formas de regular as condições de trabalho eram necessárias, assim como a convicção de que caberia ao Estado fomentá-las (idem, p. 48).

A proposta da Comissão Real para enfrentar os desafios econômicos e reduzir o conflito nas relações de trabalho era o incentivo à criação de mecanismos permanentes de negociação coletiva e resolução de conflitos em nível setorial, especialmente sobre salários. O relatório da comissão julgava que a definição de condições setoriais comuns teria o duplo resultado de reduzir os conflitos entre trabalhadores e empresários e estabilizar a concorrência entre firmas.

A opção por incentivar um sistema de negociação coletiva setorial, em que os atores coletivos do trabalho e do capital, não representou, porém, a não-interferência do Estado ou a ausência de mecanismos estatais de regulação das relações de trabalho. No início do século XX, após a conquista da imunidade de ação sindical, o propósito dos governos era produzir estruturas permanentes de negociação em todos os setores da economia e sua atuação concentrou-se naqueles em que os próprios atores não haviam criado, por uma série de razões, essa estrutura e nos quais o conflito nas relações era mais agudo, prejudicando a produção. Com efeito, a regulação direta das relações de trabalho era limitada. Ainda assim, como assevera Howell, “ao invés de legislar sobre salários, condições e estruturas de negociação o Estado agiu para prover serviços de arbitragem e conciliação, para intervir em greves para gerar acordos, e para aprovar legislação auxiliar para suportar e encorajar negociações setoriais” (2005, p. 47. Traduz-se ${ }^{84}$ ).

Essa ação fazia-se necessária em virtude dos problemas de coordenação de atores no interior de cada classe e, conseqüentemente, as dificuldades para promover ações coletivas. As cisões no interior das classes, como já afirmado, eram agudas, e havia intensa competição entre organizações. Ademais, havia em alguns setores relutância em reconhecer sindicatos e aceitar negociações coletivas. Por essas razões, parecia claro a

${ }^{84}$ No original: "instead of legislating wages, conditions, and bargaining structures the state acted to provide arbitration and conciliation services, to intervene in strikes to bring about a settlement, and to pass auxiliary legislation to underpin and encourage industry bargaining” (HOWELL, 2005, p. 47). 
setores do Estado que sua intervenção seria necessária para superar os problemas de ação coletiva dos atores e a relutância em negociar (HOWELL, 2005, p. 48).

O Estado deveria fomentar essa forma de regulação das relações de trabalho por meio de incentivos. Desse modo, o sistema regulatório baseado em negociações setoriais foi construído por meio da progressiva formação de capacidade estatal de promoção de instituições setoriais permanentes de barganha coletiva e arbitragem de conflitos. Não caberia ao Estado impor as condições a serem observadas na relação de trabalho, mas criar condições para permitir que os atores negociassem coletivamente em cada setor sobre salários, mecanismos de reajustes e jornadas (HOWELL, 2005, pp. 47 e 59). O papel fundamental da regulação jurídica não foi legislar sobre as condições da relação de trabalho em si, mas fomentar as instituições pelas quais os próprios atores regulassem as suas relações. O direito exerceu o papel de prover incentivos e sanções que permitissem superar problemas de organização e conduzissem os atores a adotar mecanismos de negociação coletiva e arbitragem de conflitos. Em setores que relutavam em instituir formas permanentes de negociação ou nos quais a organização dos atores era muito fraca, o direito permitia a intervenção do Estado para construir instituições embrionárias ou definir legalmente pisos salariais. Em nenhuma hipótese, portanto, o direito substituía a capacidade de negociação das partes.

O início desse processo deu-se pela edição da Conciliation Act (Lei de Conciliação) de 1867 que conferiu ao Home Office ${ }^{85}$, a competência para promover formas voluntárias de conciliação e arbitragem. Centrado na manutenção da ordem interna, o órgão não fez uso de sua competência e recusou-se a intervir em conflitos, senão com esse intuito. Como resultado das prescrições da Comissão de 1894 e o reconhecimento do êxito de experiências de negociação setorial, foi aprovada em 1896 o Conciliation (Trade Disputes) Act (Lei de Conciliação (Disputas de trabalho)) (REID, 2005, p. 166). Essa nova lei mantinha o caráter voluntário e a permissão ao governo de mediar conflitos se ambas as partes autorizassem, mas transferiu a competência ao Board of Trade (Conselho de Comércio), órgão encarregado da regulação do comércio. Ao contrário do Home Office, reconhecendo os efeitos econômicos dos conflitos trabalhistas o Board of Trade fez largo uso da prerrogativa e criou estruturas específicas para essa função. Primeiro, desenvolveu o Labour Statistics Bureau (Burô de Estatísticas do Trabalho) para melhor compreender os conflitos e, depois, o Labour Department (Departamento do Trabalho), que contava com

${ }^{85}$ O Home Office é órgão que compõe o gabinete Executivo do governo britânico e tem por missão manter a ordem interna. Equivale aos ministérios do interior. 
negociadores e árbitros profissionais para a promoção de mecanismos de solução de conflitos para racionalizar as relações de trabalho (idem, p. 266). No período imediatamente anterior à Primeira Guerra Mundial, o órgão interveio em muitos conflitos de maior monta, sempre recomendando que se negociasse setorialmente a criação de instrumentos permanentes de solução de disputas e definição de condições gerais de trabalho para prevenir conflitos futuros (HOWELL, 2005, p. 66).

Nessa atuação ainda incipiente, o órgão reconheceu que o maior empecilho para a adoção desses mecanismos não era a falta de interesse, mas a incapacidade organizacional dos atores para produzir entendimentos de modo autônomo, sem a participação do Estado. Daí porque, em suas intervenções em conflitos, concentrou esforços em recomendar e facilitar acordos sobre a formação de aparatos de negociação, o reconhecimento dos sindicatos e procedimentos de solução de controvérsias (HOWELL, 2005, p. 67). "Entre 1906 e 1914 o Board of Trade interveio em mais de 85\% das disputas industriais principais, resolvendo 75\% dessas” (idem, 2005, p. 68. Traduz-se ${ }^{86}$ ).

Como forma de incentivar os atores a adotar mecanismos de negociação setorial, o governo empregou constantemente a ameaça de produção legislativa, impondo formas compulsórias de arbitragem e órgãos que definiriam pisos salariais setoriais. O fundamento para essa ameaça o Trade Boards Act de 1909, que permitia à administração criar órgãos de negociação incluindo representantes das empresas, dos sindicatos e do governo, em setores nos quais os salários eram muito baixos e os atores não suficientemente organizados (HOWELL, 2005, p. 69). Nesses setores, em que acordos não podiam ser produzidos, o Estado utilizou sua prerrogativa de criar órgãos denominados trade boards, que podiam definir condições e salários mínimos que possuíam caráter legal e, desse modo, eram vinculantes. Em suma, nos setores em que os atores eram organizados, o Estado apenas necessitava persuadi-los a criar mecanismos de negociação coletiva. Já naqueles em que os atores eram debilmente organizados, o Estado criou embriões de instituições permanentes de negociação de salários e condições, permitindo que chegassem a acordos autônomos.

Certamente o emprego do direito na regulação das relações trabalhistas foi mais intenso durante a Primeira Guerra Mundial, quando o potencial de danos advindos de disputas trabalhistas e interrupções na produção era mais elevado e a mobilização nacional exigia ordem absoluta no local de trabalho. Ainda assim, a administração não alterou a

${ }^{86}$ No original: "Between 1906 and 1914 the Board of Trade intervened in over 85 percent of major industrial disputes, resolving 75 percent of them” (HOWELL, 2005, p. 68). 
trajetória de sua intervenção regulatória, apenas aproveitando o controle mais intenso que exercia sobre a produção para promover instituições de negociação setorial (HOWELL, 2005, p. 75). Era necessário garantir eficientes procedimentos de solução de conflitos emergentes das relações de trabalho. As medidas tomadas, especialmente, por meio do Munitions Act (Lei de Munições) de 1915, proibiram as greves e os lockouts, impuseram o reconhecimento dos sindicatos, tornaram compulsória a arbitragem de conflitos e estenderam mecanismos de negociação salarial para atingir mais de um terço da força de trabalho (idem, p. 70). Outra medida para facilitar negociações entre atores, foi o incentivo à centralização das organizações representativas de trabalhadores e empresários. O deslocamento do foco da negociação para o nível setorial nacional conferiu poder a negociadores profissionais dos sindicatos.

Ao final da Guerra o receio que o relaxamento dos controles sobre o trabalho pudesse conduzir a um incremento dos conflitos trabalhistas motivou a formação do Comitê Whitley. Esse, como reconhece Howell (2005, p. 71), compartilhou as conclusões da Comissão Real de 1894, reforçando a convicção do Estado na utilidade da negociação coletiva setorial, dos sindicatos e no voluntarismo. A intervenção do Estado na regulação das relações de trabalho deveria ser acessória, limitada às hipóteses em que atores não produziam acordos próprios.

A adoção do relatório da comissão pelo gabinete governamental conduziu à edição de leis criando dois novos órgãos de regulação das relações trabalhistas. Antes deles, porém, o governo criou, em 1918, o Ministério do Trabalho, desenvolvendo uma burocracia específica para lidar com os temas relacionados às relações de trabalho e separando-os dos assuntos comerciais. O primeiro desses órgãos foi produto da edição de um novo Trade Boards Act, no mesmo ano. Referida lei autorizava recém-criado Ministério do Trabalho a persuadir atores a criar Joint Industrial Councils (JIC Conselhos Industriais Conjuntos). Os JICs deveriam ser voluntariamente criados para promover a negociação coletiva setorial. A lei também estendeu a competência do Ministério do Trabalho de criar trade boards, não apenas em setores nos quais os salários eram baixos, mas também naqueles em que o baixo grau de organização dos atores impedia a formação de acordos (HOWELL, 2005, p. 72). O intuito da lei era que a negociação florescesse em todos os setores, quer por meio de um JIC, quer por meio de trade boards. Mais uma vez, a ameaça de criação de trade boards, cujos acordos eram legalmente vinculantes, era utilizada como instrumento para persuadir setores a formar 
voluntariamente JICs. Outro argumento empregado no período foi o de que apenas os JICs e os trade boards seriam considerados interlocutores legítimos em negociações com o governo, ou autores de demandas (idem, p. 73).

A Comissão Whitley também produziu os tribunais industriais, fruto do Industrial Courts Act (Lei dos Tribunais Industriais), de 1919 (HOWELL, 2005, p. 72). A lei autorizava o Ministro do Trabalho a criar tribunais industriais para arbitrar os conflitos trabalhistas mais graves, assim considerados os que provavelmente gerariam mobilizações nacionais ou que causassem prejuízos mais significativos à economia e à sociedade (idem, p. 75). Esses tribunais deveriam ser compostos por três membros, sendo um neutro, um representando os empresários e o outro os trabalhadores do setor em que a disputa se desenvolvia.

A Segunda Guerra Mundial constituiu, como a Primeira, mais uma oportunidade de empregar controles mais rígidos sobre a produção orientada para os esforços bélicos como instrumento para a construção de instituições permanentes de negociação coletiva e solução de conflitos. No período de guerra, 55 novos JICs foram criados e mesmo instituições de negociação das condições de trabalho no interior das empresas foram incentivadas (HOWELL, 2005, p. 90). Novamente, a legislação assumiu um papel mais ativo de regulação. A Ordem 1305 proibiu as greves e os lockouts, tornando a arbitragem compulsória e autorizou oficiais do Ministério do Trabalho a utilizar seu dever de intervenção em disputas trabalhistas coletivas para promover o reconhecimento sindical e mecanismos de negociação conjunta (idem, p. 92).

A inovação mais significativa do documento foi, porém, a criação do Tribunal Nacional de Arbitragem (National Arbitration Tribunal), ao qual o Ministro do Trabalho poderia submeter disputas trabalhistas coletivas. Esse tribunal deveria, nos casos concretos, observar os termos e condições reconhecidas pelo setor cujos atores estavam em conflito, o que equivalia a um acordo setorial. Ademais, suas decisões eram consideradas vinculantes e incorporadas aos contratos dos trabalhadores envolvidos na disputa. Essas duas determinações do documento tinham conseqüências expressivas para a regulação do trabalho: em primeiro lugar, tornava os acordos setoriais vinculantes, já que o seu descumprimento podia ser invocado pela parte lesada e suprido por determinação judicial. Em segundo lugar, fomentava a negociação setorial, pois exigia que as decisões estivessem fundamentadas nos termos e condições reconhecidas pelo setor cujos atores estavam em conflito, o que equivalia a um acordo setorial. Em terceiro lugar, estendia as condições e 
termos negociados para todos os trabalhadores de um setor, mesmo que seus patrões não houvessem participado da negociação, uma vez que, bastava que o setor possuísse um acordo para que os trabalhadores pleiteassem a incorporação de seus termos a seus contratos. Esse último efeito representava, ainda, um reconhecimento indireto dos sindicatos pelos empresários que não haviam participado da negociação e, ao submetê-los ao acordo, incentivava-os a participar para que seus interesses fossem considerados (HOWELL, 2005, p. 91).

Esses dispositivos são ainda mais relevantes porque foram adotados pela legislação posterior. A Ordem 1305 permaneceu em vigor até 1951 e a legislação que a substituiu - a Ordem 1376, até 1959, e o Terms and Conditions of Employment Act (Ato dos Termos e Condições de Emprego) a partir desse ano - manteve esses dispositivos, apenas alterando a denominação do órgão jurisdicional responsável por garantir a aplicação das condições e termos acordados, primeiro para Tribunal de Disputas Industriais (Industrial Disputes Tribunal), e depois para Corte Industrial (Industrial Court) (HOWELL, 2005, p. 91).

Em 1945, o Wages Councils Act (Lei dos Conselhos de Salários) substituiu os trade boards pelos wage councils (conselhos de salários). Wages councils constituíam uma “forma híbrida entre a regulação legal de salários e a negociação coletiva” (HOWELL, 2005, p. 92), já que o resultado da negociação entre as partes, um piso salarial setorial, era legalmente vinculante. Como seus antecessores, os wage councils foram imaginados como o mecanismo regulatório de salários nos setores em que aparatos de negociação não existiam, mas o Estado podia criá-los também em casos em que a negociação era inadequada ou seria provável que deixasse de existir (idem, p. 92).

A nacionalização de indústrias estratégicas no período posterior à Segunda Guerra conduziu à adoção nesses setores de instituições permanentes de negociação nacional pelo empregador estatal, promovendo uma extensão do sistema de negociação para setores em que não existia e para empregados que assumiam funções de administração e gerência, ocupações ainda com pouca tradição organizacional (HOWELL, 2005, p. 90).

Pode-se observar, portanto, que essa forma de regulação das relações de trabalho e seus incentivos estatais perduraram com vigor até o período posterior à Segunda Guerra Mundial. A cobertura dos acordos nacionais sobre salários atingiu mais de $70 \%$ dos trabalhadores em 1950, crescimento resultante tanto da expansão de mecanismos de negociação coletiva adotados por atores representativos de setores da economia, quanto da definição legal de salários em setores em que esses mecanismos não existiam e os salários 
eram muito baixos. A cobertura desses acordos era 30\% maior do que a densidade sindical no mesmo período, o que indicava que o sistema de regulação das relações de trabalho incentivado pelo Estado havia estendido sua influência além dos trabalhadores sindicalizados (HOWELL, 2005, pp. 89-90).

A utilidade do sistema de negociação setorial tornou-se consensual e o apoio dos atores à sua continuidade foi intenso. Em parte, esse apoio era explicado pelo êxito do sistema em solucionar os problemas mais comuns das indústrias rudimentares, limitando a concorrência baseada em redução de custos e reduzir os conflitos entre sindicatos e empresários (HOWELL, 2005, p. 80). As relações puderam ser reguladas voluntariamente pelos atores com mínima intervenção legal. Não havia obrigatoriedade legal de reconhecer sindicatos, submeter-se à arbitragem de conflitos ou garantias para o cumprimento dos termos acordados pelas partes. Ainda assim, o papel do direito foi relevante: coube à legislação oferecer incentivos para a negociação setorial e fornecer recursos organizacionais aos setores mais fracos, por meio da criação de embriões de instituições de negociação. Ademais, ele protegeu os sindicatos do direito produzido pelos juízes, garantindo a imunidade dos sindicatos em relação ao Common Law.

No caso dos empresários, esse apoio também era motivado pelas vantagens do modelo. Além de regular a concorrência entre as firmas do mesmo setor, o sistema mantinha a liberdade de negociação das condições de trabalho, o que era preferível à imposição legislativa de condições homogêneas e permanentes. Uma das qualidades do sistema negocial era, com efeito, permitir alterações conforme as circunstâncias e a correlação de forças entre as partes (HOWELL, 2005, p. 55). Ademais, a negociação em nível setorial mantinha intocada a prerrogativa dos empresários de organizar os processos de trabalho no interior da firma como melhor entendessem, não interferindo em assuntos internos. O deslocamento das negociações do local de trabalho reduziu a influência dos sindicatos nas empresas (HOWELL, 2005, p. 56; REID, 2005, p. 165), o que garantia aos empresários maior controle sobre a produção. Por fim, a negociação setorial envolveu freqüentemente a criação de procedimentos de solução de disputas, quer de arbitragem, quer de conciliação, que limitavam a capacidade dos sindicatos de fazer greves e interromper a produção.

Para os trabalhadores, a principal vantagem do sistema era o reconhecimento indireto dos sindicatos, possibilitado pelas negociações setoriais, que necessitavam de um representante definido para os trabalhadores. O sistema não garantia um procedimento 
específico para o reconhecimento sindical, mas ao incentivar a negociação, também promovia o reconhecimento dos sindicatos como interlocutores legítimos (HOWELL, 2005, p. 81). Além disso, o sistema solucionou, em diversos casos, problemas de organização, que impediam o estabelecimento de canais de negociação e acordo com os empresários, estabelecendo instituições para tanto.

Em termos gerais, o êxito do sistema reforçou a convicção no laissez-faire coletivo e a preferência por um sistema voluntário de regulação das relações de trabalho. Para os sindicatos, o modelo reforçou a preferência pelas imunidades e o rechaço de direitos positivos (HOWELL, 2005, p. 84). Alterou, ademais, as estruturas e padrões de ação das organizações sindicais. O deslocamento dos esforços negociais para o nível setorial conduziu à fusão de sindicatos menores, por meio da formação de federações nacionais (HYMAN, 2003; REID, 2005, p. 165), à formação de negociadores profissionais que atuam em âmbito nacional e a um distanciamento entre as lideranças sindicais e as bases. Esse movimento retirou a capacidade dos sindicatos de negociar assuntos internos às empresas, concentrando-se em demandas comuns aos trabalhadores do setor e, notadamente, por aumentos salariais. Por outro lado, os trabalhadores e seus representantes no interior das empresas permaneciam livres para encaminhar demandas específicas, sobre as quais os sindicatos não tinham capacidade de controle (HOWELL, 2005, p. 58).

\subsubsection{A crise, sua narrativa e seu diagnóstico pela Comissão Donovan}

O apreço e o consenso, tanto dos atores das relações de trabalho, quanto da sociedade como um todo, em torno do sistema voluntário de negociação coletiva setorial permaneceram inabalados até a metade da década de 1950, quando novos desafios econômicos expuseram as limitações desse sistema. A transição da indústria britânica das formas de produção artesanais para métodos de produção massificada havia se completado, com o declínio das primeiras e o aumento da centralidade das últimas para a economia britânica. Essas grandes indústrias pertenciam a setores com menos agentes econômicos e, por isso, a concorrência e seus efeitos sobre salários e condições de trabalho não estavam entre os problemas que tinham de enfrentar (HOWELL, 2005, p. 94). Embora mais modernas que as indústrias rudimentares que ainda adotavam métodos de manufatura desenvolvidos na revolução industrial, as empresas britânicas destinadas à produção em 
massa de bens padronizados tinham desvantagens em relação a suas concorrentes de outros países, menor intensidade tecnológica e grau de organização científica da produção (HYMAN, 2003, p. 42). A grande preocupação dessas empresas era, portanto, recobrar a competitividade, por meio de uma modernização dos processos produtivos que permitisse um incremento da produtividade. Essa modernização no interior das firmas pressupunha a modificação das rotinas, funções e práticas dos trabalhadores de acordo com interesses da gerência e, sobretudo, o abandono pelos trabalhadores de práticas que limitassem a produtividade. Por um lado, portanto, esse processo exigiria que a gerência mantivesse ou recobrasse suas prerrogativas de organizar a produção e o trabalho. Por outro, demandaria o envolvimento e o consentimento dos trabalhadores, uma vez que qualquer iniciativa unilateral encontraria resistência por parte dos trabalhadores (HOWELL, 2005, p. 87). Em suma, seriam necessárias novas instituições para negociar as mudanças ou, ao menos, eliminar a resistência dos trabalhadores a elas.

Diversos aspectos do sistema de negociações setoriais sobre salários e condições gerais de trabalho incentivado pelo Estado tornavam-no inapropriado para permitir a negociação dessas mudanças produtivas. Os acordos setoriais não versavam sobre aspectos internos das empresas, como a organização do trabalho, uma das razões, aliás, pelas quais contavam com o apoio dos empresários. Esse sistema buscara, em favor do empresariado, “neutralizar” a presença dos sindicatos do local de trabalho, retirando dele a negociação. Por essa razão, excluira aspectos de organização do trabalho das negociações e deslocara a presença e os recursos das organizações representativas dos trabalhadores para negociações nacionais. A organização e a regulação dos processos produtivos eram definidas unilateralmente pela gerência, negociadas informalmente entre trabalhadores e gerentes em setores em que a organização daqueles era mais forte, ou até mesmo controladas pelos próprios trabalhadores (HYMAN, 2003, pp. 42-3; HOWELL, 2005, pp. 88, 96).

Com o fortalecimento da organização dos trabalhadores no interior das empresas, que agiam paralelamente a seus sindicatos, a habilidade da gerência de controlar os processos produtivos e promover mudanças era cada vez menor. Suas tentativas de recobrar esse controle enfrentavam, obviamente, grande resistência dos trabalhadores, que temiam demissões e alterações nas demarcações profissionais. Portanto, as estruturas de negociação vigentes não se mostravam mais capazes de neutralizar o local de trabalho, assegurando o controle sobre a produção e sobre os trabalhadores ou reduzir a resistência desses às alterações na produção. Os sindicatos mantinham-se, com efeito, distantes das 
empresas, mas também dos trabalhadores que constituíam suas bases, oferecendo espaço para que esses agissem por si só. Não tinham como controlar suas bases ou garantir a observância aos termos acordados setorialmente que, aliás, não eram vinculantes. Também não havia mecanismos legais que assegurassem o cumprimento dos acordos, já que tanto empresários quanto trabalhadores eram contrários a imposições legislativas (HOWELL, 2005, p. 96; REID, 2005).

Essa circunstância permitia aos trabalhadores organizar ações no interior das firmas com demandas para além daquelas negociadas setorialmente e organizar a resistência a iniciativas de mudanças produtivas (TURNER, 1969, p. 4). Na prática, as condições salariais em muitos casos eram definidas no interior de cada empresa e como resultado de pressões de seus trabalhadores e do interesse dos empresários de oferecer concessões em troca da aceitação de alterações nos processos de trabalho. Em decorrência, os salários eram reajustados sem refletir aumentos da produção ou do custo de vida, o que provocava pressões inflacionárias.

Ademais, as estruturas existentes de negociação setorial não eram adequadas para discutir formas de organização do trabalho que elevassem a produtividade, já que essas constituem aspectos específicos de cada empresa. Pelo contrário, essas negociações, ao definir condições homogêneas para todas as empresas, ainda que limitadas a salários, jornadas de trabalho e mecanismos de solução de controvérsias, constituíam um empecilho à adoção de políticas salariais particulares que funcionassem como incentivo à produção, assim como à emergência de procedimentos de negociação no interior da firma, por consumir os recursos organizacionais das associações de empresários e de trabalhadores.

Outro problema associado a essas estruturas era o baixo peso relativo dos setores mais dinâmicos da indústria, justamente os que requeriam novas formas de negociação dos processos produtivos para manter suas condições de competição, nas associações de empresários. As condições impostas não consideravam, portanto, os anseios das grandes empresas (HOWELL, 2005, p. 95).

Embora algumas das inadequações do sistema de negociação setorial estivessem relacionadas ao fortalecimento de seu poder de barganha, também para os trabalhadores havia nele limitações. A principal delas era a ausência de um mecanismo que garantisse o reconhecimento sindical pelos empresários. Como analisado anteriormente, o reconhecimento era uma decorrência da constituição de aparatos de negociação coletiva. Em setores em que os empresários eram mais resistentes à negociação, os sindicatos não 
tinham como obter o reconhecimento. Ocorre que, em meados do século passado, as alterações na estrutura ocupacional conduziam a um aumento sustentado dos empregos nos setores de serviços, justamente nos quais os empresários mostravam-se mais resistentes a negociar coletivamente as condições de trabalho ou reconhecer sindicatos. Essa resistência produzia conflitos nos setores, os quais não podiam ser solucionados por ausência de instrumentos regulatórios (HOWELL, 2005, p. 97).

Essa inadequação, reconhecida pelos atores na década de 1960, provocou um significativo incremento do conflito trabalhista. As causas do conflito não estavam relacionadas às negociações setoriais e, por isso, não havia nenhum mecanismo regulatório capaz de solucioná-los. Em realidade, três eram as principais causas da forte mobilização dos trabalhadores no período, que ocorria sob um contexto de fortalecimento dos sindicatos e da organização dos trabalhadores no interior das firmas, todas relacionadas às inadequações já mencionadas. A primeira delas corresponde às tentativas de recuperar a produtividade empresarial por meio de alterações nos processos produtivos e de subordinar reajustes salariais a ganhos de produtividade, que geravam grande resistência. A segunda das causas era a impossibilidade de alguns trabalhadores, especialmente aqueles que desempenhavam atividades gerenciais e administrativas e ocupações no setor de serviços, obterem o reconhecimento de seus sindicatos pela relutância dos empresários. A última era o conjunto de políticas salariais adotadas pelos governos nas décadas de 1960 e 1970, como forma de impedir ajustes salariais excessivos e controlar a inflação. Esses conflitos tornavam-se mais prejudiciais à economia porque não havia instituições, capazes de processá-los de modo eficaz (HOWELL, 2005; REID, 2005).

Diante dessas inadequações e da nova onda de conflitos e greves, grandes empresas passaram a buscar alternativas às negociações informais. Algumas dessas empresas abandonaram as associações empresariais setoriais e passaram a desenvolver acordos de produtividade independentes com seus funcionários. Esses acordos envolviam freqüentemente o compromisso dos trabalhadores de elevar a produtividade, aceitando novas condições de trabalho mais flexíveis e abandonando práticas restritivas e greves como forma de expressão de demandas, em troca de melhores salários e condições de trabalho (HOWELL, 2005, p. 95; REID, 2005, p. 303). As empresas estavam dispostas a negociar concessões em troca do consentimento com as inovações produtivas.

Além da inadequação do sistema vigente para negociar as mudanças necessárias na produção, o questionamento do modo como o Estado vinha regulando as relações de 
trabalho, meramente incentivando a formação de instituições de negociação setorial, também é produto de uma narrativa de crise nas relações de trabalho que proliferava na sociedade, promovida pela grande imprensa. Essa narrativa constituía uma hipérbole dos conflitos nas relações coletivas de trabalho na década de 1960 em alguns setores específicos. Centrava sua atenção na figura dos representantes dos trabalhadores no interior das empresas, os shop stewards, que coordenavam práticas restritivas, assim como no grande número de greves não-oficiais, isto é, realizadas por trabalhadores de companhias específicas sem a aprovação dos sindicatos. Essa hiperbólica narrativa exagerava os aspectos prejudiciais para a economia do conflito industrial e responsabilizava a excessiva liberdade de ação sindical, materializada na imunidade em relação ao controle judicial. Essa imunidade era compreendida como um privilégio que colocava os sindicatos acima da lei (TURNER, 1969, p. 5; HOWELL, 2005, pp. 100-1; REID, 2005, p. 299). Conseqüentemente, essa narrativa da crise era acompanhada da proposta de estabelecimento de responsabilidades legais para os sindicatos.

Com efeito, o pleno emprego e os recursos organizacionais que as instituições de negociação coletiva ofereceram aos sindicatos haviam fortalecido os sindicatos e seu poder de restringir e interromper a produção. Todavia, os prejuízos ocasionados pela ação sindical estavam relacionados à ausência de instituições regulatórias para processar os conflitos. Ademais, essa narrativa, que apontava que mecanismos informais nos locais de trabalho de encaminhamento de demandas provocada desordem e constantes interrupções da produção, era válida apenas para alguns poucos setores, especialmente o automobilístico, em que os conflitos haviam ganhado significativa visibilidade pública (HOWELL, 2005, p. 98; REID, 2005, p. 294). Ainda assim, o problema foi definido como sendo o excesso de greves não-oficiais e a ausência de mecanismos de responsabilização dos sindicatos por sua ação (HOWELL, 2005, pp. 99-100).

Assim, diante do crescimento da consciência sobre o declínio da indústria britânica e da assunção de responsabilidade aos sindicatos, reformas para limitar seu poder e implementar novas formas de regulação das relações de trabalho são propostas (HOWELL, 2005, p. 87; REID, 2005, p. 299). A polêmica sobre o poder dos sindicatos e os custos dos conflitos precipitou, mais uma vez, uma onda de ativismo judicial. Em 1964, ao decidir o caso Rookes v. Bernard, a Câmara dos Lordes limitou seriamente a imunidade em relação ao controle judicial de que gozavam os sindicatos em suas manifestações (TURNER, 1969, p. 1). A decisão determinou que os sindicatos seriam responsáveis pela ameaça ou violação 
efetiva do contrato de trabalho e estipulou uma sanção pelos danos provocados (punitive damages). Dessa forma, um dos pilares do laissez-faire coletivo, existente desde 1906, era eliminado.

O governo trabalhista que assumiu o poder no mesmo ano estava decidido a restaurar a situação legal anterior dos sindicatos (TURNER, 1969, p. 1). Em 1965, um novo Trade Disputes Act foi aprovado para reafirmar a isenção de responsabilidade dos sindicatos em ações de dano propostas por trabalhadores excluídos de closed shops ${ }^{87}$, isto é, demitidos por não serem filiados ao sindicato reconhecido pela empresa, anulando o entendimento esposado na decisão da Câmara dos Lordes (REID, 2005, p. 386).

Contudo, era necessário também responder aos anseios relativos aos custos dos conflitos trabalhistas e a inadequação das instituições regulatórias, bem como propor novas formas de processar esses conflitos (HOWELL, 2005, p. 101). Para fundamentar ações futuras e determinar as melhores formas de solucionar a crise regulatória, o governo decidiu convocar uma Comissão Real sobre Sindicatos e Associação de Empregadores em 1965, coordenada por Lord Donovan, cujo nome passou a designar a comissão. O propósito era proceder a um exaustivo estudo do estado das relações de trabalho na GrãBretanha e, a partir de uma pesquisa abrangente, propor desenvolvimentos para a regulação das relações de trabalho. Por essa razão, a Comissão contou com a participação de notáveis acadêmicos, além de políticos e representantes de trabalhadores e empresários. Esses acadêmicos, fundadores do campo das relações industriais na universidade britânica como Kahn-Freund, Hugh Clegg e Allan Flanders, produziram pesquisas que embasaram o relatório final da Comissão (REID, 2005, p. 300).

Em seus 1.112 parágrafos, o relatório final produzido pela Comissão reafirmou a convicção no voluntarismo, na utilidade dos sindicatos e da negociação coletiva para regular as relações de trabalho e, em resposta às pressões da sociedade e de alguns políticos por maior intervenção legislativa, na limitação do papel do direito para regular os conflitos e responsabilizar com sanções a ação sindical (HOWELL, 2005, p. 104; REID, 2005, p. 300). Nesse sentido, vale citar Kahn-Freund, quem sintetiza na seguinte afirmação a convicção da maioria dos relatores da Comissão na ineficácia de uma legislação punitiva para limitar a ação sindical:

87 Closed shops (oficinas fechadas) são estabelecimentos empresariais em que a filiação sindical é considerada uma condição para o emprego. Essa condição é fruto de um acordo entre o sindicato e a empresa, pelo qual esta concorda em contratar apenas membros do sindicato que reconhece como interlocutor. Assim sendo, esse arranjo permite aos sindicatos controlar a seleção dos empregados. Esses acordos eram permitidos na Grã-Bretanha até a década de 1980. 
Certos aspectos das relações de trabalho não podem ser controlados pelo direito. O direito provavelmente será um fracasso sempre que ele procurar neutralizar hábitos de ação ou inação adotados por um número elevado de homens e mulheres em observância a costumes sociais estabelecidos, normas de conduta ou convicções éticas ou religiosas. Políticas para controlar movimentos espontâneos de greves por meio de ameaças de penalidades ou responsabilização civil estão condenadas a falhar [...] $(1970 \text {, p. 241) })^{88}$

O relatório não sucumbia por completo à difundida narrativa da crise regulatória e da desordem no trabalho. Seu diagnóstico reconhecia a desfuncionalidade do sistema voluntário que o Estado havia promovido desde o início do século XX, assim como a "baixa produtividade, práticas de trabalho restritivas, greves não-oficiais e a deriva salarial com conseqüências inflacionárias” (HOWELL, 2005, p. 102. Traduz-se ${ }^{89}$ ). Contudo, exonerava os trabalhadores e os sindicatos da responsabilidade pelas anomalias das formas como as relações de trabalho eram determinadas.

A tese central de seu diagnóstico, repetido insistentemente sempre que a Comissão Donovan é analisada, é o reconhecimento da convivência de dois sistemas de regulação das relações de trabalho: um sistema formal representado por acordos coletivos firmados por instituições formais de negociação setorial; e um sistema informal que consiste em entendimentos no interior do local de trabalho entre trabalhadores, seus representantes, gerentes, sindicatos e associações de empresários (Report of the Royal Commission on Trade Unions and Employers' Associations, par. 46). A causa dos problemas residiria, de acordo com o relatório, no conflito entre ambos os sistemas. O sistema informal teria se tornado o lócus mais importante de regulação das relações, pois nele ocorreria a negociação mais substantiva (idem, par. 154), comprometendo os efeitos regulatórios do sistema formal. Os entendimentos informais e a autoridade dos gerentes e dos representantes dos trabalhadores no interior das firmas, os shop stewards, haviam sido promovidos por esses mesmos atores, que preferiam negociar entre si e não encontravam meios de vocalizar suas demandas no sistema formal. Entretanto, as condições definidas por meio desse sistema invalidavam os termos acordados setorialmente (TURNER, 1969,

\footnotetext{
${ }^{88}$ No original: "Certain aspects of labour relations cannot be controlled by law. The law is likely to be a failure whenever it seeks to counteract habits of action or of inaction adopted by large numbers of men and women in pursuance of established social custom, norms of conduct or ethical or religious convictions. Policies to control spontaneous strike movements by threats of penalties or civil
} liabilities are doomed to failure [...]” (KAHN-FREUND, 1970, p. 241).

89 No original: "poor productivity, restrictive labor practices, unofficial strikes, and wage drift with inflationary consequences” (HOWELL, 2005, p. 102). 
p. 4). Desse modo, os sindicatos não podiam ser responsabilizados pelo conflito, já que, relativamente ausentes do local de trabalho, tinham limitado controle sobre as bases e participação nesses entendimentos informais.

Considerando a importância das negociações intrafirmas e a preferência dos atores por essas, o relatório da Comissão Donovan propõe a institucionalização da negociação coletiva no interior das empresas. A negociação setorial deveria continuar em operação para definir padrões gerais mínimos, enquanto que a negociação no interior das empresas deveria ser promovida com o intuito de regular salários reais, procedimentos de solução de conflitos e práticas de trabalho. O conteúdo dos acordos, portanto, deveria ser estendido para além de salários, jornada de trabalho e procedimentos de solução de conflitos, de modo a incluir aspectos da organização dos processos de trabalho que ampliassem a produtividade (HOWELL, 2005, p. 88; REID, 2005). A proposta era promover uma transformação negociada dos processos produtivos, compartilhando o controle sobre os mesmos para retomá-lo, e estava fundada no pressuposto de que esses mecanismos de negociação interna permitiriam superar a resistência dos trabalhadores (HOWELL, 2005, p. 104).

Os sindicatos são instados a formalizar o papel dos representantes dos trabalhadores no interior das empresas e facilitar sua atuação. As associações de empresários, por sua vez, a deslocar sua ênfase para o interior das empresas e auxiliá-las a desenvolver mecanismos de negociação, assim como a reconhecer sindicatos. Como forma de evitar as pressões inflacionárias e práticas restritivas, o relatório recomendava a adoção de acordos de produtividade, associando ganhos salariais a aumento na produção. (HOWELL, 2005, pp. 104-5). Ao Estado, por fim, caberia fornecer incentivos para a formalização de mecanismos de negociação no interior das empresas.

Uma posição minoritária na Comissão defendia uma postura mais interventiva do Estado, que garantisse o cumprimento dos acordos coletivos e ampliasse o corpo de direitos positivos individuais dos trabalhadores. Também havia críticos da posição adotada pela Comissão, tanto entre os conservadores, quanto entre analistas mais radicais. Os primeiros consideravam as conclusões muito brandas e propunham a adoção de sanções legais para as ações sindicais e novos (HOWELL, 2005). Os segundos apontavam que a Comissão apontava como anomalia era, em realidade, o mero reflexo do fortalecimento dos trabalhadores e de suas organizações, assim como de seu esforço para recobrar o controle sobre os processos produtivos e aprofundar a democracia nos locais de trabalho. 
Desse modo, a racionalização da negociação no interior das empresas seria uma forma de garantir o controle gerencial e limitar a força dos trabalhadores (TURNER, 1969; GOLDTHORPE, 1974).

Não obstante o notável valor analítico e os méritos do relatório, suas conclusões não refletiam o sentimento coletivo e o ânimo político, razões pelas quais muitas de suas propostas não foram implementadas. A reação do público é de descrédito, considerando as medidas tímidas para reduzir as greves que paralisavam a economia nacional (HOWELL, 2005, p. 108). Julgando necessárias respostas mais incisivas, os governos iniciaram uma era de experimentos de intervenção legislativa na ação sindical. Ainda assim, as propostas de descentralizar as negociações e estender seu escopo para incluir questões relacionadas aos processos de trabalho e acordos de produtividade foram adotadas por inúmeras empresas e sindicatos (idem, p. 109).

\subsubsection{Tentativas de reforma negociada}

Ao relatório final da Comissão Donovan seguiram-se três tentativas de reforma do sistema de regulação das relações de trabalho, todas atribuindo um papel mais ativo ao direito no controle da ação sindical. As tentativas buscavam incluir os sindicatos no processo de reforma, condição que era julgada necessária para superar a resistência e possibilitar a adoção de novos processos produtivos nas empresas. Em consonância com as propostas do relatório Donovan, essas tentativas de reforma reconheciam a necessidade de promover a construção de novos mecanismos regulatórios no interior das empresas e, para tanto, oferecer recursos organizacionais para reforçar a presença dos sindicatos nesse âmbito. Por esse meio, julgava-se, seria possível disciplinar o trabalho no interior da firma e negociar as reformas necessárias nos processos produtivos.

Mais uma vez, a intervenção em conflitos episódicos era empregada pela administração estatal como pretexto para persuadir as partes a criar mecanismos de negociação no interior das firmas. Contudo, os propósitos estreitos de controlar as greves e impor restrições às pretensões salariais para impedir pressões inflacionárias minavam o potencial de reformas mais abrangentes (HOWELL, 2005, p. 110).

A Comissão Donovan já ocorrera em um contexto de maior intervenção estatal nas relações de trabalho. Desde o início da década de 1960, os governos vinham empregando 
com maior intensidade o direito como um mecanismo de regulação das relações de trabalho e um corpo de direitos trabalhistas individuais vinha sendo produzido, a despeito do pouco interesse de sindicatos e empresários por essa forma de regulação. Considerando imperativa para reduzir a resistência à modernização dos processos produtivos e à recuperação econômica, a administração editou leis que promoviam a mobilidade do trabalho, facilitando a transição entre empregos. Com o intuito de melhor a qualificação da mão-de-obra britânica e solucionar problemas de ação coletiva na área de treinamento, foi promulgada em 1964 o Industrial Training Act (Ato de Treinamento Industrial). No campo da seguridade social, foi introduzido o salário-desemprego por meio do Redundancy Payments Act (Ato de Pagamentos por Desemprego), de 1964, e um seguro social nacional, dois anos depois, pelo National Insurance Act (Ato do Seguro Nacional) (HOWELL, 2005, p. 111).

Além dos direitos individuais criados na primeira metade da década, a administração havia edificado um fórum nacional para a discussão de estratégias de reestruturação econômica e solução de problemas comuns. O National Economic Development Council (Conselho de Desenvolvimento Econômico Nacional) era formado por representantes do governo, do empresariado e dos trabalhadores e visava igualmente a facilitar os processos de transformação da produção por meio da negociação (HOWELL, 2005, p. 111; REID, 2005, p. 381). O órgão também integrava os esforços, ainda incipientes, de facilitar a aceitação de uma política de rendas que fosse capaz de controlar a inflação.

As iniciativas de reforma após a Comissão Donovan também procuravam ampliar os direitos trabalhistas individuais como meio de regulação das relações de trabalho e a coordenação de esforços em torno da planificação econômica. A primeira resposta estatal após a publicação do relatório foi delineada pelos trabalhistas a partir de um documento propositivo, intitulado No Lugar do Conflito (In the Place of Strife), de 1969. Por um lado, o documento adotava algumas das propostas do Relatório Donovan, dentre as quais a criação de uma Comissão de Relações Industriais (Commission on Industrial Relations, CIR), perante a qual seriam registrados os acordos coletivos. Ao órgão também deveria ser concedida a competência para intervir nos casos em que o reconhecimento sindical era recusado pelo empresariado. Por outro, contraditava o mesmo relatório ao impor limites à ação sindical, exigindo votação prévia à realização de greves e prevendo o direito da administração estatal de impor uma pausa conciliatória em casos de greves não-oficiais, 
assim consideradas as que não eram realizadas de acordo com as regras dos sindicatos (HOWELL, 2005, p. 111).

O documento foi empregado pelo Primeiro-Ministro Harold Wilson como base de uma curta proposta legislativa que oferecia aos sindicatos um intercâmbio: o direito de pertencer a um sindicato e o poder da CIR de impor o reconhecimento do sindicato aos empresários eram concedidos em troca de limitações ao direito de greve, tais como o direito da administração de fixar uma pausa em greves não-oficiais de 28 dias para negociação e de definir uma solução para greves produzidas por disputas entre sindicatos. O TUC rejeitou a proposta, e diante de sucessivos congelamentos salariais determinados por políticas de rendas, abandonou o Partido Trabalhista à sua própria sorte, conduzindo à eleição do Conservador Edward Heath em 1970 (HOWELL, 2005, p. 112; REID, 2005, p. 386).

Informado pelas pressões conservadoras por maior intervenção e controle nas relações de trabalho, o novo governo aprovou já em 1971 uma lei que reorganizava substancialmente as relações coletivas de trabalho na Grã-Bretanha, relativizando o princípio do laissez-faire coletivo. O Industrial Relations Act (Lei das Relações Industriais, IRA) revogou toda a legislação precedente que tratava dos sindicatos. A despeito de sua extensão, o fulcro da lei era o mesmo da proposta fracassada do governo anterior: em troca de um procedimento legal para garantir o reconhecimento sindical, a lei impunha limites às greves. Inspirada no modelo regulatório estadunidense, a lei incluía um procedimento para o reconhecimento de sindicatos, que seria operado pelo mesmo CIR, mas também previa um período de pausa durante disputas trabalhistas coletivas e introduzia uma nova categoria de práticas de trabalho injustas (“unfair labour practices”), que seria objeto de análise da nova Corte Nacional de Relações Industriais (National Industrial Relations Court - NIRC). A lei trazia inúmeras disposições que buscavam limitar as ações sindicais interruptivas da produção: restringia as imunidades sindicais, tornando os sindicais responsáveis por suas ações relacionadas a conflitos intersindicais e manifestações secundárias, em apoio a outros setores; conferia poderes emergenciais ao Estado de intervir em greves consideradas danosas à comunidade ou à economia e o direito de exigir uma votação para verificar o apoio dos trabalhadores à greve; tornava os acordos coletivos legalmente vinculantes e, portanto, executáveis judicialmente, a menos que as partes explicitamente determinassem de modo diverso, bem como incentivava a criação de procedimentos obrigatórios de solução de conflitos que evitassem as greves; por fim, 
introduzia o direito individual de proteção contra a demissão injusta, criando um remédio alternativo às greves para contestar o encerramento da relação de emprego (HOWELL, 2005, pp. 112-3).

Novamente os sindicatos rejeitaram a reforma legislativa e ignoraram o procedimento previsto para o reconhecimento sindical oferecido pelo IRA. Os trabalhadores não estavam dispostos a se submeter ao controle estatal e aos elementos coercitivos associados em troca desse reconhecimento. Ademais, reconhecendo a sua incapacidade, pela limitada capacidade organizacional, de controlar seus membros para garantir o cumprimento dos termos acordados, os sindicatos recusaram-se a se engajar em negociações vinculantes, acrescentando cláusulas que expressamente determinavam que os acordos não teriam essa natureza. Os empregadores também se negaram a empregar a legislação, pois punições não solucionavam os conflitos, não reduziam a resistência dos trabalhadores, nem tampouco conquistava a lealdade dos mesmos. E, por fim, a própria administração passou a negligenciar a existência da lei, não fazendo uso dos poderes e mecanismos de controle que a mesma os oferecia, assim que necessitou do apoio dos trabalhadores para uma nova política salarial (HOWELL, 2005, p. 113).

Em 1974, um novo governo trabalhista assumiu o poder com amplo apoio sindical. Sua plataforma na área da regulação das relações de trabalho havia sido conjuntamente deliberada com os sindicatos, que ofereciam apoio ao governo e suas políticas de restrição salarial em troca da revogação do IRA e da promulgação de uma nova legislação que promovesse os direitos coletivos e a democracia industrial. Ao invés de adotar políticas salariais compulsórias, a administração preferira um sistema voluntário de moderação das pretensões salariais, negociado com o TUC (REID, 2005, p. 387). Ao contrário do que ocorrera no período anterior, os sindicatos aceitaram os custos de controle de seus membros em virtude de um pacote de benefícios oferecidos pelo governo trabalhista que incluía, além de alterações legislativas, subsídios para alimentos, o congelamento dos preços dos aluguéis, controles de preços e mudanças no imposto de renda. Esse acordo, conhecido como o Contrato Social (Social Contract), foi a única iniciativa de concerto continuado, ainda que breve, entre sindicatos e governo (REGINI, 1984, pp. 136-7).

No que se refere, à regulação do trabalho, a aliança entre o Partido Trabalhista e o TUC, desenvolvera um programa de reformas legislativas que tinha como ato inaugural a revogação do IRA e sua substituição pelo Trade Union and Labour Relations Act (TULRA - Ato das Relações de Trabalho e dos Sindicatos) em 1974. A nova lei não representou 
uma inovação, senão uma restauração do status legal anterior às tentativas de reformas e à decisão no caso Rookes v. Barnard. O documento reeditou a imunidade ilimitada de ação conferida aos sindicatos em relação à intervenção judicial pela legislação em 1906, reafirmando o princípio do laissez-faire coletivo. É certo que o restabelecimento da imunidade sindical possibilitou à lei limitar o direito dos empresários de recorrer a medidas cautelares contra greves. Não obstante, revelando o grande apego dos sindicatos, que contribuíram com a redação da lei, pelo voluntarismo e sua reticência de adotar formas legais de regulação, a lei não estabeleceu um direito positivo à greve (HOWELL, 2005, p. 114).

A segunda iniciativa foi a aprovação, em 1975, do Employment Protection Act (Ato de Proteção do Emprego - EPA). Ao contrário do documento anterior, o EPA trouxe inovações e sua redação contou com amplo apoio do TUC (REID, 2005, p. 386). Dentre todas as iniciativas legislativas da década de 1970, o EPA foi aquela que mais se aproximou das prescrições e do espírito da Comissão Donovan, assumindo como objetivo primordial a extensão e formalização dos mecanismos de negociação coletiva no interior da empresa, descentralizando a atuação das entidades representativas dos trabalhadores (HOWELL, 2005, p. 115).

Para tanto, criou um conjunto de direitos trabalhistas individuais, imaginados não como um meio de regulação substantiva das condições de trabalho e redução do espaço negocial dos atores mas, ao contrário, como instrumentos de fortalecimento da negociação coletiva no interior das empresas. Esses direitos reforçavam as capacidades de organização e ação coletiva dos sindicatos no interior das empresas, constituindo uma singular inovação do sistema regulatório britânico. Dentre os direitos concedidos incluía-se: o financiamento público para o treinamento de representantes sindicais no interior das empresas, licença para exercício de atividades sindicais, consulta prévia sobre demissões e disponibilização de informações relevantes para a negociação coletiva (HOWELL, 2005, p. 115). Em realidade, tratava-se de recursos organizacionais pelos quais a administração procurava incentivar os sindicatos a concentrarem seus esforços no interior do local de trabalho, reduzindo os custos da adaptação de suas estruturas centradas na negociação setorial. Além de constituir um uso singular dos direitos trabalhistas individuais como forma de promover a negociação coletiva, esses mecanismos revelavam uma mudança da posição tradicional dos sindicatos de rechaçar toda forma de legislação. A partir desse momento, essa defesa 
seletiva da legislação como meio de fomento ao espaço negocial tornou-se um elemento central das estratégias dos movimentos sindicais (idem, p. 115).

À parte desses recursos organizacionais, o EPA também concedeu direitos individuais tradicionais, como a licença-maternidade de seis semanas, estendeu a proteção contra a demissão injusta, já presente no IRA. Esses direitos foram acompanhados de outros conferidos por outras leis, como a proibição da demissão de gestantes e a proibição da discriminação no trabalho com base no sexo e na raça (HOWELL, 2005, p. 115; REID, 2005, p. 387).

Como incentivo à negociação no interior das empresas e ao reconhecimento sindical, o EPA estendeu a validade dos termos e condições que regulavam o contrato de empregados semelhantes no mesmo setor a trabalhadores que alegassem estar subordinados a condições menos favoráveis. O direito podia ser pleiteado perante o Advisory, Conciliation and Arbitration Service (ACAS - Serviço de Aconselhamento, Conciliação e Arbitragem), um novo órgão criado com o intuito de facilitar a negociação coletiva, mesmo nas hipóteses em que não havia um acordo coletivo. Nesses casos, a pretensão basear-se-ia em condições gerais de trabalho observadas no setor. O mecanismo foi eficiente para garantir o reconhecimento a setores em que não havia instituições de negociação coletiva, como o de serviços, pois o empresário preferia definir condições com seus empregados do que aceitar a imposição de condições determinadas pelo ACAS (HOWELL, 2005, p. 116). Ainda assim, não era suficiente para garantir o reconhecimento dos sindicatos perante algumas empresas que se recusavam a participar de negociações.

Nesse sentido, o EPA estabeleceu o direito legal ao reconhecimento dos sindicatos. Se resistida a pretensão, os sindicatos podiam recorrer ao ACAS, que deveria investigar, intentar uma conciliação e, se necessário, determinar a legitimidade da pretensão pelo reconhecimento. Contudo, o dispositivo não contava com uma sanção ou outro meio de impor o cumprimento da determinação, compelindo o empresário a reconhecer o sindicato. Assim como ocorria com a Ordem 1376, a única conseqüência para os empresários da relutância em reconhecer o sindicato era a alteração dos termos e condições que regulavam os contratos de seus empregados (HOWELL, 2005, p. 115). Desse modo, o descumprimento tinha um custo relativamente baixo e se tornou comum. O ACAS logo reconheceu que a falta de cooperação dos empresários tornava suas decisões ineficazes, o que levou à revogação do procedimento e da competência do ACAS para auxiliar no reconhecimento dos sindicatos (idem, p. 118). A ineficácia do procedimento promovido 
pelo ACAS tornou-se ainda mais ineficiente após decisões judiciais em casos que questionavam decisões do ACAS pelo reconhecimento sindical, o Judiciário reconheceu o direito das empresas de não participar em negociações e a impossibilidade de imposição do reconhecimento (HOWELL, 2005, p. 125).

Como o reconhecimento sindical era a condição sine qua non da negociação coletiva no interior das empresas e de uma solução negociada para os desafios de reestruturação produtiva na Grã-Bretanha, essa relutância representava o fracasso do projeto. Nem todos os empresários mostravam-se sem disposição para engajar-se em negociações coletivas no local do trabalho. Alguns deles haviam sido os pioneiros na construção de instituições para fomentar acordos no local de trabalho sobre a produção, que serviram de base para as conclusões do Relatório Donovan. Outros reconheceram o valor dessas conclusões e, dispostos a solucionar os conflitos relacionados às transformações nos processos produtivos, havia promovido mecanismos de diálogo e negociação (HOWELL, 2005, p. 125). Contudo, não havia um consenso em torno desse sistema e alguns empresários recusavam-se a compartilhar o controle das rotinas de trabalho com os sindicatos. A negociação em nível setorial mantinha sua prerrogativa de organizar a produção, mas a negociação no interior das empresas, versando justamente sobre processos produtivos, limitava essa prerrogativa. Ademais, alguns empresários temiam que, com a formalização do diálogo no interior das empresas, os empregados que representavam os sindicatos - os shop stewards - seriam fortalecidos e ganhariam o controle sobre a produção (HOWELL, 2005, p. 118). A opinião de que seria necessário negociar as mudanças produtivas com os trabalhadores para superar sua resistência e evitar conflitos tornou-se ainda mais rara ao final da década de 1970, diante do fracasso das reformas legislativas, da manutenção de níveis elevados de conflito trabalhista e, sobretudo, de transformações socioeconômicas que exigiam dos empresários maior flexibilidade e dinamismo na produção. A decorrência lógica da percepção de que os acordos enrijeciam as condições de produção era o desejo de recobrar o controle absoluto da produção para promover essa flexibilidade.

Outra razão para o fracasso do projeto de reforma das instituições de regulação do trabalho do Contrato Social foi a ruptura do próprio, ao final de 1977, diante da incapacidade do TUC e dos sindicatos de manter a disciplina no local de trabalho e a moderação salarial (REGINI, 1984, p. 138). A política salarial praticada tornava, desse modo, também o apoio dos trabalhadores às iniciativas governamentais frágeis o que se 
traduzia, por sua vez, na fraqueza da administração que fora eleita identificando-se com os interesses dos trabalhadores. Em realidade, a retirada de apoio dos trabalhadores às políticas de controle salarial revelava a contradição entre a iniciativa de centralização da definição de salários, por meio dessas políticas e a proposta de descentralização da estrutura sindical e de negociação coletiva (HOWELL, 2005, p. 125). Por fim, a manutenção de um elevado nível de conflitos trabalhistas fomentava na opinião pública o diagnóstico da desordem no mundo do trabalho e os receios sobre seus efeitos sobre a economia. O consenso social em torno da utilidade dos sindicatos como meios de organização e disciplina dos trabalhadores era relativizado à medida que a imprensa destacava alguns conflitos específicos, paralisações de serviços públicos por melhores salários que foram notabilizadas como o Inverno do Descontentamento (Winter of Discontent), na passagem de 1978 para 1979, como se houvessem mobilizado toda a classe trabalhadora (REID, 2005, p. 384). A falta de suficiente consenso político e apoio às reformas trabalhistas pelos atores envolvidos e a sociedade abria espaço para uma nova forma de abordar o problema da regulação das relações de trabalho e da transformação de processos produtivos sem a participação ou consulta dos sindicatos (HOWELL, 2005, p. 123).

A despeito da pouca longevidade da proposta do Contrato Social, ele produziu alguns efeitos significativos nas relações de trabalho e na ação sindical. Houve, em primeiro lugar, uma expansão da negociação coletiva como meio de regulação das relações de trabalho para novos setores da economia, para o interior da empresa, e de modo a abarcar novos temas, incluindo o processo de modernização dos processos produtivos e o incremento da produtividade (HOWELL, 2005, p. 119). Essa expansão representou, em especial, a emergência de uma estrutura descentralizada de negociações, para a qual era necessário o fortalecimento da capacidade de organização dos sindicatos no interior das empresas (idem, p. 120). A legislação subsidiou a criação dessa capacidade, preparando os sindicatos para essa nova forma de negociação (idem, p. 121). Essa descentralização da negociação, por sua vez, teve como efeitos o reforço dos vínculos entre os sindicatos e suas bases por meio da proliferação de representantes sindicais no interior dos locais de trabalho, os shop stewards, e uma descentralização também da estrutura burocrática e de poder. A atuação pulverizada exigia maior abertura da burocracia a diversas demandas de trabalhadores de empresas específicas. Além disso, o deslocamento da negociação para o interior da empresa fomentou um maior ativismo por parte dos filiados e uma maior 
capacidade de perseguir interesses próprios com maior independência. O aumento do número de negociantes fomentou, ainda, o debate interno e a disputa pelo poder nos sindicatos. Por outro lado, a representação sindical no interior da empresa formalizou-se e profissionalizou-se (idem, p. 123). Um último efeito da regulação no período foi permitir a expansão do sindicalismo e das negociações coletivas para novos setores, incluindo ocupações gerenciais, funcionários públicos e do setor de serviços (idem, p. 121). Esse fenômeno traduziu-se no maior nível de densidade sindical já registrado, de 55,4\% da população trabalhadora em 1979 (idem, p. 122).

De um modo geral, o período testemunhou uma grande força mobilizadora dos sindicatos e uma capacidade elevada de agir em busca de seus interesses, aplicando sanções ao empresariado se necessário, na forma de limitações ou interrupções da produção. Esse poder também se manifestava no interior das empresas, onde os trabalhadores possuíam significativo poder sobre a produção e, desse modo, eram capazes de resistir a transformações. A base desse fortalecimento era não apenas a imunidade de ação, mas também o conjunto de recursos organizacionais que o Estado conferiu, por meio de instrumentos legais e administrativos aos sindicatos, o que não era reconhecido pelo sindicalismo naquele então (HOWELL, 2005). Por essa razão, ao mesmo tempo em que os sindicatos eram fortalecidos pelo laissez-faire coletivo e pela promoção da negociação coletiva pelo Estado, a ausência de garantias legais na forma de direitos positivos tornava os sindicatos vulneráveis a ataques políticos. O período posterior evidenciou essa realidade.

\subsection{A descoletivização da regulação do trabalho}

A narrativa da crise e da desordem nas relações de trabalho atinge seu ápice no inverno de 1978, quando as imagens dos serviços públicos suspensos por greves no setor público percorreram a Grã-Bretanha causando enorme indignação. O fracasso do Contrato Social e a retirada do TUC e dos sindicatos de seu apoio às políticas de controle salarial, pela incapacidade de controlar o descontentamento dos trabalhadores com as mesmas, havia enfraquecido o governo trabalhista de James Callaghan e abria espaço para as pesadas críticas da liderança conservadora à pretensamente desenfreada liberdade sindical que equivaleria a uma tirania. Disputando a eleição com um programa de reforma das 
instituições de regulação das relações de trabalho que incluía uma forte intervenção na ação sindical, Margareth Thatcher soube capitalizar o sentimento coletivo e venceu as eleições de 1979 com um respeitável apoio.

O fracasso das tentativas de reforma das instituições de regulação das relações de trabalho na década de 1970 e a conseqüente manutenção do nível elevado de conflitos trabalhistas apenas reforçaram a convicção da liderança conservadora de que a responsabilidade pela estagnação econômica e pelas dificuldades de promover uma reestruturação nos processos produtivos era dos sindicatos e das instituições de negociação coletiva. Os primeiros representariam uma força desmesurada na sociedade, porquanto ilimitada pela lei, e as últimas, uma rigidez inaceitável que limitava a capacidade de resposta dos atores econômicos á dinâmica econômica, obstaculizando o crescimento da Grã-Bretanha (JESSOP, 1994; HOWELL, 2005).

Conseqüentemente, quando os conservadores assumiram o poder em 1979, a estratégia adotada para reestruturar a produção, agora com destaque no incremento da flexibilidade dos processos e usos do trabalho, foi radicalmente diferente daquelas que a antecederam. Thatcher e seus ministros consideravam que as forças de mercado e incentivos estatais seriam suficientes para restaurar a competitividade na Grã-Bretanha (JESSOP; SUM, 2006, p. 211). Mas para que fosse assim, era necessário eliminar os constrangimentos ao pleno desenvolvimento dessas forças. O trabalho organizado era reputado como o principal o maior desses obstáculos.

No período anterior julgava-se que era necessário promover uma forma negociada de modernização dos processos e rotinas produtivas para recuperar a competitividade do produto britânico. Argumentava-se que sem obter o consentimento e colaboração dos trabalhadores, não seria possível superar sua resistência a essas alterações, razão pela qual o aparato regulatório deveria fomentar essa negociação. A liderança conservadora tinha uma opinião contrária, de acordo com a qual seria a negociação sobre os rumos da produção que impediria a reestruturação, que demandaria a retomada da prerrogativa gerencial de organizar sem interferências os processos produtivos. A modernização desses só poderia ocorrer se o poder dos sindicatos fosse neutralizado. Logo, a estratégia adotada pelos conservadores para assegurar formas mais flexíveis da produção de bens e serviços para formas mais flexíveis consistia na promoção de uma guerra contra os sindicatos, com o intuito de promover a descoletivização das relações de trabalho e reduzir a resistência a mudanças (HOWELL, 2005). 
Essa estratégia de debilitação dos sindicatos envolveu a criação de uma miríade de disposições legais limitando suas ações e eliminando a imunidade que havia imperado, a despeito dos ataques judiciais, desde 1906. Essas disposições integravam nada menos que sete leis promulgadas entre 1980 e 1993. As leis e as principais limitações introduzidas são elencadas na tabela a seguir:

Tabela 4: A reforma legislativa conservadora e os limites à ação sindical

\begin{tabular}{|c|c|}
\hline Documento legal & Principais determinações \\
\hline $\begin{array}{l}\text { Employment Act } \\
1980\end{array}$ & $\begin{array}{l}\text { Introduz obrigatoriedade de realização de votação entre os filiados para: } \\
\text { - } \quad \text { Iniciar ou terminar uma ação que represente interrupção da produção, tal } \\
\text { como greves; } \\
\text { - } \quad \text { Emendar regras da constituição dos sindicatos; } \\
\text { - } \quad \text { Eleger lideranças e decidir se sindicato irá se engajar em acordos do tipo } \\
\text { closed shop, requerendo para sua aprovação 80\% de aprovação. } \\
\text { Restringe piquetes legais: } \\
\text { - } \quad \text { Ao local de trabalho do empregado envolvido; } \\
\text { - Ao propósito exclusivo de pacificamente obter ou comunicar informação, } \\
\text { ou ainda persuadir qualquer pessoa a trabalhar ou abster-se de trabalhar, } \\
\text { também pacificamente; } \\
\text { Todos os atos realizados no curso de um piquete são passíveis de } \\
\text { responsabilização legal. }\end{array}$ \\
\hline $\begin{array}{l}\text { Employment Act } \\
1982\end{array}$ & $\begin{array}{l}\text { Considera injusta a demissão em decorrência da não-filiação sindical de um } \\
\text { empregado em uma empresa com acordo de closed shop. Prevê compensação } \\
\text { pecuniária ao demitido nessas circunstâncias; } \\
\text { Proíbe cláusulas de exigência de filiação sindical em contratos; } \\
\text { Restringe a imunidade dos sindicatos, permitindo sua responsabilização por } \\
\text { danos provocados em suas ações. }\end{array}$ \\
\hline $\begin{array}{l}\text { Trade Union Act } \\
1984\end{array}$ & $\begin{array}{l}\text { Introduz a necessidade de escrutínios secretos periódicos para: } \\
\text { - } \quad \text { Eleger os membros dos principais comitês executivos; } \\
\text { - } \quad \text { Promover ações que representem interrupção da produção, tal como } \\
\text { greves; } \\
\text { - } \quad \text { Manter ou estabelecer fundos de financiamento a políticos; } \\
\text { Estabelece responsabilidade para empregados e empregadores pela realização } \\
\text { de ações não-oficiais, isto é, não precedidas de uma votação válida. }\end{array}$ \\
\hline $\begin{array}{l}\text { Employment Act } \\
1988\end{array}$ & $\begin{array}{l}\text { Proíbe ações para obrigar a filiação sindical. Essas ações são passíveis de } \\
\text { responsabilização. } \\
\text { Aumenta controles e interferências sobre a administração dos sindicatos, } \\
\text { pretensamente para assegurar maior transparência, incluindo entre os }\end{array}$ \\
\hline
\end{tabular}




\begin{tabular}{|c|c|}
\hline & $\begin{array}{l}\text { instrumentos: } \\
\text { - Direito de inspecionar os registros contábeis dos sindicatos; } \\
\text { - Direito de requerer ao empregador que suspensa as deduções de } \\
\text { contribuições devidas ao sindicato; } \\
\text { Cria o Comissário para os Direitos dos Membros de Sindicatos, funcionário } \\
\text { encarregado de investigar reclamações contra a gestão sindical. }\end{array}$ \\
\hline $\begin{array}{l}\text { Employment Act } \\
1990\end{array}$ & $\begin{array}{l}\text { Torna ilegal recusar o emprego, ou qualquer serviço de uma agência de } \\
\text { emprego, em virtude da não-filiação sindical (ou da filiação); } \\
\text { Autoriza os empregadores a demitir funcionários que participaram de greves } \\
\text { não-oficiais. }\end{array}$ \\
\hline $\begin{array}{l}\text { Trade Union and } \\
\text { Labour Relations } \\
\text { (Consolidation) Act } \\
1992\end{array}$ & $\begin{array}{l}\text { Consolida as regras anteriores; } \\
\text { Aumenta as hipóteses de responsabilidade dos sindicatos; } \\
\text { Cria o dever de manter registros contábeis e realizar auditorias; } \\
\text { Estabelece o direito de qualquer trabalhador de desfiliar-se e requerer que o } \\
\text { empregador deixe de deduzir de seus salários a contribuição sindical. }\end{array}$ \\
\hline $\begin{array}{l}\text { Trade Union Reform } \\
\text { and Employment } \\
\text { Rights Act } \\
1993\end{array}$ & $\begin{array}{l}\text { Introduz votação por correio para incluir membros não militantes nas eleições; } \\
\text { Cria os tribunais industriais, responsáveis por dirimir conflitos envolvendo } \\
\text { relações individuais e coletivas de trabalho; } \\
\text { Cria o Tribunal de Apelação do Emprego, órgão de revisão das decisões. }\end{array}$ \\
\hline
\end{tabular}

É fácil identificar nesses documentos legais múltiplas restrições à ação sindical, bem como a introdução de controles à administração interna dos sindicatos. O conjunto desses dispositivos promovia um controle efetivo sobre a ação sindical, não verificado nas tentativas anteriores. O caráter distintivo que garantia essa eficácia era o caráter civil das sanções aplicáveis aos sindicatos. Ao contrário das sanções penais, a responsabilização civil desperta menos ressentimento e representa custos de aplicação menores.

Contudo, o esforço para restringir as ações sindicais e reduzir seu poder não se limitou, porém, à produção legislativa. A aplicação das leis pelas autoridades também se tornou mais estrita, e os conservadores não hesitaram em empregar medidas repressivas contra ações sindicais. Forças policiais eram comumente empregadas para dissuadir manifestações e restaurar a ordem. O caso paradigmático do emprego de forças de segurança para coibir a ação sindical foi a greve dos mineiros, organizada em resposta ao fechamento das minas de carvão nacionais e que se prolongou por uma ano entre 1984 e 1985. Além de manter forças policiais presentes em todas as manifestações dos mineiros, órgãos de inteligência infiltraram-se no movimento.

O projeto de enfraquecimento dos sindicatos incluiu, ainda, o desmantelamento dos órgãos estatais de negociação e coordenação, por meio dos quais os sindicatos podiam 
vocalizar demandas políticas e interferir na própria regulação estatal das relações de trabalho. Os casos de desativação do National Economic Development Council (Conselho de Desenvolvimento Econômico Nacional), criado para debater soluções planificadas para desafios comuns da economia, e dos Wage Councils (Conselhos de Salários), estrutura que determinava pisos salariais legalmente vinculantes em setores sem aparatos de negociação coletiva, foram os mais notórios do período. Outros órgãos de coordenação de atores foram mantidos, mas sucessivas alterações excluíram a representação em seu interior dos sindicatos, sempre que seus interesses pudessem contrastar ou obstruir os do governo e do capital. As instituições estatais destinadas à promoção do treinamento vocacional e da educação profissional constituem o exemplo mais claro da exclusão dos sindicatos. Progressivamente delegadas a gestores privados com metas de desempenho, essas instituições deixaram de consultar os sindicatos e considerar suas reivindicações nessa questão (KEEP; RAINBIRD, 2003, p. 313).

Por meio dessas alterações, legislativas e administrativas, o governo de Thatcher encerrou um longo período de vigência do período do laissez-faire coletivo, do incentivo à regulação voluntária das relações de trabalho e das imunidades sindicais, todos pilares que pareciam inabaláveis. Ademais, interrompeu o fluxo de recursos organizacionais que o Estado oferecia aos sindicatos desde o início do século. Mais bem, as medidas redirecionaram os recursos para os empresários, permitindo que esses pudessem retomar o controle da produção sem a resistência dos sindicatos. O direito foi empregado, portanto, para controlar e enfraquecer os sindicatos, por um lado, e potencializar a ação empresarial, por outro.

Essas medidas consubstanciavam um projeto de descoletivização das relações de trabalho que, como afirmado, era compreendido como um meio de garantir maior flexibilidade a essas relações. Como a regulação legal das relações de trabalho na GrãBretanha era limitada e apenas acessória em relação à regulação por meio de negociação coletiva, não havia muitos direitos que eliminar para promover maior flexibilidade nas relações de trabalho, como pretendiam os empresários. Por essa razão, demandas por maior flexibilidade estavam especialmente associadas à liberdade para negociar condições de trabalho individualmente. A flexibilização das relações de trabalho foi alcançada não por meio de revogação de direitos individuais, mas sim por meio de um ataque sustentado aos sindicatos que promoveu uma progressiva descoletivização da regulação das condições de trabalho (DICKENS; HALL, 2003, p. 130). 
Não obstante, as reformas legislativas no período também reduziram os direitos individuais dos trabalhadores. O período de qualificação para a obtenção de saláriodesemprego e indenização por demissão injusta foi elevado de seis meses para dois anos. Durante o governo conservador de John Major, essas iniciativas foram contrabalanceadas pela incorporação de diretivas sociais européias, as quais embora enfrentassem muita resistência da administração conservadora, foram consideradas legalmente vinculantes pela Câmara dos Lordes (DICKENS; HALL, 2003, p. 127) ${ }^{90}$.

A cobertura da rede de proteção social também foi limitada. Seus programas foram subordinados a políticas de estabilização fiscal, que visavam a reduzir os gastos públicos. Desse modo, introduziram-se regras mais estritas de elegibilidade e alguns serviços foram concedidos à iniciativa privada. Ao reduzir a rede de proteção social, a administração também serviu para impor a disciplina do mercado aos trabalhadores (KING; WOOD, 2005). Em meio a um contexto de desemprego elevado, a redução dos meios alternativos de subsistência condenava os trabalhadores a aceitar empregos contingentes e com baixos salários.

O êxito das profundas alterações que, em pouco tempo, lograram erodir o princípio regulatório fundamental das relações de trabalho na Grã-Bretanha, estava associado às próprias características do modelo regulatório vigente, mas também ao apoio dos empresários, à reação dos trabalhadores e a conseqüências particulares do projeto Thatcheriano que o alimentavam.

A ausência de direitos positivos e garantias aos sindicatos e o limitado corpo de direitos trabalhistas individuais tornavam os trabalhadores e suas organizações representativas mais vulneráveis a ataques políticos. Não havia instituições e políticas estatais que representassem obstáculos consideráveis à reforma. Todo o sistema de regulação jurídica continuava, ao final da década de 1970, a despeito da maior intervenção estatal, fundado na imunidade de ação e na negociação coletiva. Instituições e políticas estatais eram destinadas a promover esses pilares, mas não interferiam diretamente nos resultados das negociações e não ofereciam direitos positivos aos trabalhadores além

\footnotetext{
${ }^{90}$ A disputa entre o Executivo e o Comitê Judicial da Câmara dos Lordes a respeito do reconhecimento das diretivas européias como direito válido na Grã-Bretanha teve seu ponto máximo no caso das Diretivas do Conselho da Europa 75/117/EEC e 76/207/EEC. Essas diretivas reconheceram aos trabalhadores em tempo parcial os mesmos direitos dos trabalhadores em tempo integral e proibiu discriminações contra o primeiro. Na Grã-Bretanha, sob o Employment Protection Act de 1978, alguns direitos não eram reconhecidos aos trabalhadores em tempo parcial e o governo recusava-se a reconhecer as diretivas. O Comitê Judicial da Câmara dos Lordes decidiu, então, que para assegurar o cumprimento do artigo 119 do Tratado de Roma, essas diretivas tinham de ser reconhecidas como válidas na Grã-Bretanha. Como conseqüência, foi aprovado o Statutory Instrument 1995 no. 31, com o mesmo conteúdo das diretivas.
} 
daqueles entendidos como necessários para fortalecer a sua capacidade associativa e as condições de negociação coletiva no interior da firma. Não havia garantias, padrões mínimos legalmente vinculantes ou proteções que devessem ser revogadas. Por conseguinte, o custo político da reforma era muito mais baixo.

A convicção no laissez-faire coletivo havia levado os sindicatos a acreditarem que seu poder era inabalável. Acreditavam que, como seu poder não estava fundado em um marco legal que lhes conferisse garantias, mas na presença em instituições voluntárias de negociação, nenhuma ação estatal poderia afetar-lhes. Não haveria nada para lhes retirar, já que o Estado não teria oferecido nada (HYMAN, 2003). Ocorre, porém, que os Estados haviam continuamente oferecido recursos organizacionais, sem que esses constituíssem direitos garantidos por lei. Dessa forma, o Estado havia sim oferecido algo aos sindicatos que podia retirar a qualquer momento, como fez Thatcher (HOWELL, 2005).

Essa posição dos sindicatos e sua reação às medidas adotadas pelo governo conservador também explicam o êxito das mesmas. Ao boicotar as políticas e reformas de Thatcher, os sindicatos pensavam estar diante da mesma situação e correlação de forças que os levaram a rejeitar a reforma proposta pelos conservadores no início da década de 1970 e a promover o Inverno do Descontentamento, como forma de rejeitar sistematicamente as políticas de renda que visavam a controlar a inflação. Julgavam que eram suficientemente fortes e organizados e que não necessitavam de nenhum suporte estatal para resistir a políticas e aplicar sanções. Consideravam ainda que as medidas seriam altamente impopulares e que a sociedade apoiaria a resistência, como fizera em situações anteriores. Desse modo, as iniciativas de Thatcher estariam fadadas ao fracasso, pois teriam um custo social, econômico e político elevadíssimo que, em um sistema político altamente centralizado como o de Westminster, a primeira-ministra não teria como suportar (HOWELL, 2005).

Tratava-se, entretanto, de um erro de cálculo. Ao final de uma década de acirrado conflito industrial e de um acalorado debate público sobre o papel dos sindicatos na limitação do crescimento e nas crises econômicas da Grã-Bretanha, os sindicatos não gozavam mais de irrestrito apoio e o consenso em torno de sua utilidade para organizar o trabalho e garantir a produção havia ruído. A imprensa, especialistas e políticos compartilhavam um mesmo diagnóstico sobre a falência do sistema regulatório das relações de trabalho que levara a uma desordem, especialmente no interior das firmas, assim como a percepção da premente necessidade de reforma. A imunidade tornara-se, na 
opinião de muitos, uma liberdade desenfreada que criava uma poderosa casta acima da lei (HYMAN, 2003; HOWELL, 2005).

O novo consenso, aliás, unindo conservadores e trabalhistas, julgava necessário, em nome da recuperação econômica britânica, frear o conflito e limitar o poder sindical, o que constituiu outro fator do êxito da reforma. Thatcher fora eleita justamente com uma plataforma de reforma na regulação das relações de trabalho que contava com o apoio do empresariado, que desejava promover novas formas produtivas mais flexíveis. Duas estratégias estavam disponíveis para tanto: os empresários podiam continuar a dialogar com os sindicatos como parceiros no processo de reestruturação e realizar acordos com esses, ou evitá-los, estabelecendo canais diretos de negociação entre a gerência e os trabalhadores (HYMAN, 1992; REGINI, 1992). A incapacidade dos sindicatos de disciplinar seus membros e a resistência dos mesmos às transformações produtivas orientavam a preferência dos empresários pela segunda opção. Portanto, parecia-lhes mais eficiente retomar o poder absoluto de determinação das rotinas e processos de trabalho, excluindo os sindicatos do processo de reestruturação e adotando mecanismos individuais de regulação das relações de trabalho. A descoletivização também lhes parecia a melhor estratégia.

Portanto, as forças sociais que a apoiavam não teriam porque se opor a medidas contra o poder dos sindicatos e o custo político das mesmas seria reduzido. As únicas forças que haveriam de se opor eram justamente os trabalhadores organizados, os quais constituam tradicionalmente o eleitorado do Partido Trabalhista, que não lograra maioria (KING; WOOD, 2003). Ademais, ao contrário do que havia sido antecipado pelos sindicatos, a reforma de Thatcher garantiu-lhe ganhos políticos, pois ao enfraquecer os sindicatos, estava limitando a principal força social de suporte à sua oposição, o Partido Trabalhista. Para alguns autores, esse produto do ataque aos sindicatos não foi acidental, mas explicitamente perseguido pela liderança conservadora (KING; WOOD, 2003; HOWELL, 2005). Ainda que a reforma não tivesse objetivos políticos, é inconteste que uma de suas medidas comprometeu uma das principais fontes de financiamento do Partido Trabalhista, os fundos políticos sindicais, criando uma série de requisitos para sua constituição, como se verá adiante.

Também os efeitos das políticas adotadas por Thatcher garantiram seu êxito. Houve um rápido aumento do desemprego e uma deterioração das condições de vida dos trabalhadores. A tendência secular de desindustrialização da Grã-Bretanha foi intensificada 
no período com o fechamento de muitos postos de trabalho. As políticas econômicas recessivas e de liberalização do mercado, promovidas pelo governo no período também promoveram o desemprego. A Era Thatcher representou o fim do pleno emprego e, com ele, o acirramento da competição entre trabalhadores pelos postos de trabalho que escasseavam. Essa crescente divisão entre trabalhadores e a redução do emprego nos setores de sindicalismo mais tradicional reduziram o número de membros e o poder de barganha dos sindicatos. Os sindicatos não podiam contar com apoio social, com o poder de punição eleitoral e sequer com sua própria força para resistir à guerra travada contra eles pela Dama de Ferro.

A bem sucedida destruição do marco coletivista de regulação das relações de trabalho logrou reduzir a resistência dos trabalhadores a alterações nos processos produtivos e promover maior flexibilidade. Promoveu, ainda, uma radical alteração no equilíbrio de poder nas relações entre empresários e trabalhadores em favor dos primeiros, devolvendo-lhes a iniciativa sobre a definição das condições de trabalho sem interferências dos sindicatos. As relações de trabalho podiam, assim, desenvolver-se sem a participação do trabalho organizado, o que conduziu a um notável enfraquecimento dos sindicatos.

Em realidade, poucos sindicatos deixaram de ser reconhecidos no período, mas as novas empresas que surgiam já inseridas em um marco individualista de regulação das relações de trabalho não mais tinham incentivos para se relacionar com os sindicatos (REID, 2005). Como no período muitas empresas mais tradicionais desapareceram, houve uma sensível queda na densidade sindical, que foi reduzida de 55,4\%, em 1979, para menos de 30\% da população trabalhadora em 2001 (HOWELL, 2005, pp. 1 e 131). Mais sensível, porém, foi a limitação do poder de sindicatos de negociar condições de trabalho e impor sanções para demandar concessões dos empresários. Os limites impostos à ação sindical e a progressiva individualização da regulação das relações de trabalho tornaram os sindicatos organizações menos combativas, mais pragmáticas e dispostas à negociação, o que se traduziu em uma queda sensível do número de greves aos menores níveis desde 1920. Ademais, os mecanismos coletivos de definição de salários, que cobriam 85\% dos trabalhadores em 1979 cederam lugar a formas individualizadas de negociação e cobriam apenas 35\% dos trabalhadores (idem, pp. 1 e 131).

Quando retornou ao poder após 18 anos de governo conservador, o Partido Trabalhista havia se modificado. O novo equilíbrio de poderes de classes e as feridas que os sindicatos haviam causado aos governos trabalhistas da década de 1970 promoveram 
uma maior separação entre o Partido e os sindicatos e uma maior identificação com interesses dos empresários (HOWELL, 2005, p. 174). O partido herdou um sindicalismo debilitado, níveis significativos de desemprego e exclusão social. No que diz respeito ao modelo de regulação das relações de trabalho, o Novo Trabalhismo, como se autodenomina, manteve as estruturas do aparato implementado pelos conservadores. Não houve alterações significativas no padrão de atuação do Estado na regulação das relações de trabalho iniciado por Thatcher. O Novo Trabalhismo não reverteu a descoletivização ou recuperou para os sindicatos o papel de destaque na definição das relações de trabalho que exercera outrora. Os direitos individuais passaram a ocupar, entretanto, um papel mais proeminente na regulação das relações de trabalho, em parte pela produção normativa da Comunidade Européia (DICKENS; HALL, 2003). Ademais, o Partido assumiu um novo discurso e práticas relativas à flexibilidade, aos conflitos trabalhistas e as políticas de mercado de trabalho.

A primeira mudança discursiva promovida pelo Novo Trabalhismo envolve a sua atitude com relação à flexibilidade dos arranjos produtivos e o uso do trabalho. Enquanto que para seus predecessores a flexibilidade era uma realidade inescapável, o governo trabalhista considera-a como uma oportunidade de ampliar tanto a competitividade, quanto a justiça no trabalho, criando novas oportunidades para empregadores e empregados (DTI, 1998, p. 10). A administração relaciona flexibilidade com escolha e liberdade para estabelecer um novo equilíbrio entre a vida e o trabalho. É com esse intuito que o governo promove arranjos de trabalho temporalmente flexíveis, que permitiriam aos trabalhadores decidir quando e por quanto tempo trabalhar, além de harmonizar suas vidas profissionais com suas tarefas familiares ou sociais. Essa concepção garantiu a concessão do direito de requerer arranjos flexíveis de trabalho, presente no Employment Act (Lei do Emprego), de 2002.

A segunda mudança discursiva corresponde a uma nova abordagem relativa aos conflitos trabalhistas. O ponto de partida dessa nova atitude é o reconhecimento das possibilidades limitadas de uma relação conflituosa entre trabalhadores, empresários e o Estado. O governo julgava necessário criar novos instrumentos para legitimar o controle exercido sobre o trabalho e assegurar relações mais cordiais que assegurassem o comprometimento e a lealdade dos trabalhadores com as metas das empresas. Nesse sentido, o novo governo trabalhista formulou a noção de "parceria no trabalho" no documento oficial em que delineava sua estratégia regulatória para as relações de trabalho, 
denominado Justiça no trabalho (Fairness at work) (DTI, 1998, p. 1). Essa concepção fomentava a adoção, no país, de instrumentos próprios da administração de recursos humanos para promover um ambiente mais cooperativo no trabalho, que se julgava benéfico para ampliar a produtividade.

Desse modo, essa nova concepção não recuperava o papel dos sindicatos ou interrompia a tendência à individualização da regulação do trabalho. Todo o corpo legislativo que restringia a ação sindical e criava controles sobre a administração interna dos sindicatos, aprovada pelos governos conservadores, permanece vigente. Ainda assim, por força da pressão de sindicatos que, após o ataque dos conservadores, consolidaram uma posição de defesa do direito como instrumento para promoção da ação coletiva (HOWELL, 2005), um procedimento de reconhecimento voluntário dos sindicatos foi criado pelo Employment Relations Act (Lei das Relações de Emprego), de 1999. Esse procedimento tem sido considerado, porém, restritivo, uma vez que exige a aprovação de 40\% dos trabalhadores da unidade de negociação (HYMAN, 2003, p. 55). Na prática, o mecanismo tem apresentado impacto limitado, já que o número de empresas que reconhecem sindicatos reduziu-se de 33\% para 27\% no período entre 1998 e 2004 (KERSLEY et al., 2006, p. 120). A negociação coletiva não recobrou sua importância e define as condições de trabalho em apenas $27 \%$ das empresas aos quais estão ligados $40 \%$ da força de trabalho britânica (idem, p. 186).

Ainda com o intuito de permitir o processamento de conflitos trabalhistas de modo mais racional, com os menores prejuízos possíveis, o Employment Act de 2002 (Lei do Emprego), autorizou as empresas a criar procedimentos internos formalizados para lidar com reclamações dos trabalhadores, demissões e a aplicação de ações disciplinares em virtude de faltas cometidas pelos mesmos. A existência de meios formais para processar conflitos no interior do local de trabalho, especialmente para fundamentar a aplicação de sanções disciplinares, ampliava a legitimidade de qualquer decisão. Por serem consideradas mais legítimas e justas, as decisões seriam facilmente aceitas pelos trabalhadores e evitariam ressentimentos que poderiam comprometer a lealdade dos trabalhadores afetados.

A previsão da criação desses procedimentos internos pelas empresas integrava uma reforma no sistema de tribunais de emprego, que tinha como intuito reduzir o volume de processos e racionalizar o processamento de conflitos individuais, reduzindo seus custos para as empresas. Representava, ademais, outra iniciativa para individualizar as relações de 
trabalho e o processamento de conflitos, em substituição a mecanismos de negociação coletiva.

Os esforços para mobilizar o comprometimento dos trabalhadores e, conseqüentemente, ampliar a produtividade, foram complementados pela expansão do corpo de direitos e proteções trabalhistas individuais. A edição de leis com novos direitos buscava garantir padrões mínimos homogêneos que substituiriam os termos gerais antes definidos por meio de negociação coletiva. Os principais direitos introduzidos ao conjunto de proteções individuais para o trabalhador estavam contidos na Working Time Directive (Diretiva sobre Tempo de Trabalho) da Comunidade Européia e no Employment Relations Act (Lei das Relações de Emprego) de 1999. Dentre as proteções introduzidas desde 1998, destacam-se: o direito dos trabalhadores em tempo parcial ao mesmo tratamento conferido aos trabalhadores em tempo integral, a extensão de alguns direitos reconhecidos a estes para trabalhadores por tempo determinado, o direito a licenças em caso de nascimento de filhos e de emergências familiares para pais e mães, a limitação da jornada semanal de trabalho a 48 horas, disposição que pode ser derrogada por interesse expresso do trabalhador e o direito do trabalhador a ser acompanhado em reclamações e procedimentos disciplinares por representantes sindicais (DICKENS; HALL, 2003, p. 132).

Outra inovação no campo dos direitos trabalhistas individuais foi a introdução do Salário Mínimo Nacional (National Minimum Wage), justificado como uma medida para reduzir a pobreza. Os trabalhistas julgam que a pobreza deve ser enfrentada por meio da inclusão no mercado de trabalho e que, para que isso seja possível, este deve oferecer salários decentes. Em meio a um processo de redução da rede de proteção social e de seus meios alternativos de subsistência, o mercado deveria oferecer condições para superar a pobreza e garantir a reprodução da força de trabalho. O governo continuou a introduzir condições obrigatórias para o recebimento de benefícios previstos em programas sociais. Esses programas foram transformados em mecanismos de inclusão forçada no mercado de trabalho, o que se convencionou denominar workfare (PECK, 2001). Conseqüentemente, a inclusão social foi subordinada à participação no mercado de trabalho e esse deveria oferecer salários que permitissem a reprodução da força de trabalho.

Em seu conjunto, os direitos introduzidos foram imaginados como uma forma de assegurar um tratamento justo aos trabalhadores, considerado um elemento promotor de um maior comprometimento com seu trabalho e, dessa forma, de incremento da produtividade. A justiça das condições de trabalho passou a ser considerada como um 
suporte para a competitividade econômica (DTI, 1998, p. 4). Desse modo, os direitos introduzidos não reduziam a habilidade dos empresários e de sua gerência de controlar os processos de trabalho ou contratar e demitir funcionários. Com efeito, como admitido por Tony Blair, a Grã-Bretanha apresenta, mesmo com a introdução desses direitos, um dos mercados de trabalho menos regulados dentre as nações de capitalismo avançado (DTI, 1998, p. 1).

Os direitos individuais introduzidos pelo governo trabalhista constituem proteções legais de natureza tradicional, semelhantes àquelas encontradas em nações com sistemas de regulação das relações de trabalho mais juridificados. A participação mais intensa da GrãBretanha na União Européia e o novo comportamento do governo em relação à legislação produzida em âmbito comunitário são fatores que explicam o crescimento do volume de regulação legislativa das condições individuais de trabalho no país. Não se tratam de direitos individuais para reforçar as condições de ação e negociação coletivas, como os propostos pelo EPA, durante a vigência do Contrato Social. Assim sendo, reduzem o espaço negocial deixado aos atores, igualmente representando uma individualização da regulação das relações de trabalho. Há, porém, uma exceção. Ao permitir o acompanhamento dos trabalhadores envolvidos em procedimentos disciplinares e reclamações, o último dispositivo elencado aponta uma nova função para os sindicatos e, dessa forma, potencializa a ação sindical. Ao contrário do que ocorrera nos períodos anteriores, porém, a legislação não oferece recursos para facilitar a adaptação dos sindicatos à nova tarefa (DICKENS; HALL, 2003).

Desse modo, pode-se concluir que o retorno dos trabalhistas ao poder não interrompeu o curso iniciado por Thatcher e mesmo as inovações deram continuidade ao espírito geral da reforma conservadora. O novo equilíbrio de poder instaurado em favor dos empresários não foi alterado e as iniciativas legislativas promovidas na última década apenas reforçaram a tendência à individualização das formas de gestão da relação de trabalho. Pesquisas têm revelado um incremento do emprego de políticas de recursos humanos no interior das empresas, substituindo a mediação sindical pela relação direta entre gerência e trabalhadores (KERSLEY et al., 2006). Evidentemente, essa tendência acarreta o enfraquecimento dos sindicatos, cada vez mais excluídos da regulação das relações de trabalho e confinados a tarefas assistenciais. Os dados empíricos do período revelam essa continuidade: em 2004, a densidade sindical correspondia a 34\% da população trabalhadora (KERSLEY et al., 2006, p. 110), os sindicatos eram reconhecidos 
por 30\% das empresas, que congregavam metade dos trabalhadores (idem, p. 119), a negociação coletiva era o meio de definição dos salários em apenas $27 \%$ das empresas e para $40 \%$ dos empregados e, por fim, greves haviam sido realizados em apenas $2 \%$ das empresas, todas elas do setor público (idem, p. 209).

\subsection{O legado dos modelos regulatórios na Grã-Bretanha e seus impactos sobre a ação sindical}

Analisados os movimentos específicos da intervenção regulatória do Estado nas relações de trabalho na Grã-Bretanha, é possível avaliar os papéis exercidos pela regulação jurídica naquele país e os seus impactos sobre a ação sindical. A análise histórica do caso britânico permite distinguir três momentos em virtude do papel que a regulação jurídica do trabalho exerceu. Do início das relações capitalistas de trabalho assalariado até o final do século XIX, o direito foi mobilizado pelo Estado britânico para reprimir todas as formas de associação dos trabalhadores e suas ações, bem como para sujeitar os trabalhadores aos ditames de seus empregadores, sancionando uma relação desigual, em benefício desses. Tanto no que se referia às relações individuais de trabalho, quanto no tocante às relações coletivas, a ênfase da regulação jurídica era no caráter punitivo penal. O forte ressentimento provocado pela repressão no período produziu, entretanto, a consciência de classe fundamental para que os trabalhadores organizassem movimentos conjuntos para a superação dessa condição de desigualdade jurídica e exclusão política. Diante da progressiva incorporação dos trabalhadores à sociedade britânica, a repressão às suas organizações e o tratamento desigual em suas relações com os empregadores atraíram, para as causas operárias, a solidariedade de amplos setores sociais. Esse apoio permitiu aos trabalhadores organizarem-se e promoverem grandes ações coordenadas nas arenas da produção e da política, a despeito dos custos impostos pela repressão.

O produto dessa mobilização intensa foi a eliminação desse direito de matriz repressiva e sua substituição pela liberdade de ação sem constrangimentos legais ou controles judiciais. A preferência pelas garantias negativas, isto é, imunidades em relação ao direito judicial, e o rechaço dos direitos positivos derivavam da experiência do período anterior, em que o direito havia sido mobilizado para reprimir e o Judiciário para limitar as conquistas legislativas. O longo processo de consolidação institucional da liberdade de 
ação sindical, interrompido inúmeras vezes por ataques judiciais, criava entre os trabalhadores uma desconfiança no potencial regulatório do direito. Como os dispositivos legais estavam sujeitos à interpretação judicial, que se mostrava favorável aos interesses dos empresários, os trabalhadores e seus sindicatos não se sentiam seguros com uma regulação baseada em direitos positivos. Preferiam, portanto, que o direito se limitasse a reconhecer a imunidade de sua ação em relação ao Common Law. Desse modo, acreditavam, podiam negociar livremente com os empregadores as condições do contrato de trabalho.

Assim sendo, a experiência histórica comum vivida pelos trabalhadores até o final do século XIX difundiu o apego a uma concepção voluntarista e a uma postura de defesa da abstenção do Estado no campo da regulação do trabalho. O laissez-faire coletivo tornou-se a regra de ouro a orientar a regulação do trabalho, defendida por todos os atores envolvidos. Sua consagração pela administração dar-se-ia com o reconhecimento jurídico das imunidades de ação sindical em 1906. Além de interferir nas preferências e na ação dos sindicatos, esse princípio orientou as políticas e instituições mobilizadas pelo Estado em seus esforços de regulação do trabalho.

Quando finalmente o Estado reconheceu a necessidade de intervir nas relações de trabalho para criar formas de solucionar os impasses da economia britânica, suas medidas procuraram incentivar arranjos voluntários entre os atores, reproduzindo esse princípio orientador. Mesmo quando o Estado interveio, sua ação objetivava produzir as condições para que os atores de um setor econômico pudessem, por livre negociação coletiva, definir os termos do contrato de trabalho. O êxito dos aparatos de negociação coletiva promovidos pelo Estado até o período posterior à Segunda Guerra Mundial reforçou, ainda mais, o apego ao laissez-faire coletivo e a renúncia às iniciativas de regulação legislativa das condições de trabalho.

Em um segundo momento, portanto, o papel do direito foi potencializar a livre negociação entre os atores que, por sua vez, seria responsável por definir os termos da relação de trabalho e dirimir conflitos que pudessem delas emergir. O direito só deveria ser empregado para regular os termos da relação de trabalho - notadamente salários - nas hipóteses em que os atores, por deficiências de coordenação, não eram capazes de fazê-lo, e quando os salários praticados fossem muito baixos. Em síntese, o direito deveria funcionar para potencializar ou completar os esforços da ação coletiva. 
Em realidade, desde que deixou se ocupar da proibição das associações sindicais, a atuação do Estado na regulação do trabalho esteve orientada à solução de desafios econômicos enfrentados pela Grã-Bretanha. Nesse sentido, a atuação do Estado teve, durante essa fase, alguns objetivos mais específicos. De início, a negociação coletiva sobre preços e condições de trabalho foi incentivada para evitar conflitos nos setores tradicionais da indústria com acirrada concorrência. Depois, diante da necessidade de promover alterações na organização produtiva para modernizar a indústria britânica e torná-la apta a competir internacionalmente, sua ação legislativa e administrativa busca promover a formalização dos mecanismos de negociação intra-firma, que mobilizavam a gerência e os trabalhadores no interior das empresas, para negociar as condições das mudanças produtivas, mantendo-se a negociação coletiva em nível setorial sobre condições gerais e pisos salariais.

Ao eleger as negociações coletivas como o instrumento fundamental de regulação das relações de trabalho, o Estado reconhecia a utilidade dos sindicatos para organizar os trabalhadores e tornava-os atores relevantes de seu sistema regulatório. Esse reconhecimento, somado à liberdade de ação e à concessão de significativos recursos, foi causa do fortalecimento dos sindicatos, suas estruturas administrativas, assim como de sua capacidade de agir e impor sanções contra seus empregadores para obter demandas. Além disso, esse poder sindical foi conquistado com um elevado grau de independência em relação ao Estado, mesmo quando os trabalhistas estavam no poder, o que é comprovado pelo fracasso das iniciativas de concerto social.

Ao final desse segundo período, o elevado poder de mobilização sindical foi interpretado pela opinião pública como a causa de uma desordem nos espaços produtivos e da impossibilidade de superar a estagnação econômica do país. As imunidades concedidas aos sindicatos eram interpretadas como privilégios que os colocavam acima da lei, conferindo-lhes um poder ilimitado. Apontava-se, ademais, que esse poder era empregado pelos sindicatos para resistir às inovações produtivas, prejudicando a sociedade como um todo.

Esse diagnóstico conduziu alguns empresários e as lideranças políticas conservadoras a acreditar que as transformações produtivas exigidas para resgatar a competitividade da economia britânica não poderiam ser realizadas com a participação dos sindicatos ou por meio de negociações coletivas. Essa percepção inaugura o terceiro momento da regulação jurídica das relações de trabalho na Grã-Bretanha. Por meio de um 
ataque sustentado aos sindicatos, que lançou mão da introdução de controles legislativos e administrativos, o propósito era alterar a correlação de forças para permitir aos empresários e seus gerentes retomarem o controle sobre os processos de trabalho, reduzindo a resistência à promoção de arranjos produtivos mais flexíveis. Para tanto, o direito foi mobilizado para impor limites à ação dos sindicatos e para oferecer recursos aos empresários para que pudessem determinar as regras de trabalho sem a resistência dos sindicatos. Por meio dessa ação, pretendia-se descoletivizar a regulação das relações de trabalho, permitindo à gerência negociar individualmente as condições de trabalho com cada trabalhador. Essa descoletivização seria instrumental à promoção da flexibilidade.

Além de estabelecer controles sobre a ação sindical, a regulação jurídica serviu nesse terceiro momento para criar mecanismos de solução de conflitos no interior das empresas e para introduzir alguns direitos individuais para os trabalhadores, em consonância com a legislação comunitária européia. O emprego de direitos positivos individuais para regular padrões mínimos a serem observados nas relações de trabalho reforçou ainda mais a tendência de individualização, reduzindo o espaço negocial deixado aos atores. Ao final desse terceiro período, o Estado havia logrado anular o poder de barganha dos sindicatos, enfraquecendo-os e tornando sua mediação desnecessária para a definição das relações de trabalho. Foi necessário o violento ataque conservador para que os sindicatos repensassem o papel da legislação e para que a convicção quase dogmática no voluntarismo fosse substituída por uma defesa seletiva de direitos que potencializem a ação coletiva. 


\section{CONCLUSÃo}

Este trabalho propõe-se a comparar historicamente os modelos de regulação jurídica das relações de trabalho na Grã-Bretanha e no Brasil e os padrões de ação sindical nas duas nações com o intuito de demonstrar como aparatos regulatórios específicos influenciaram - constituíram causa eficiente - de padrões específicos de ação sindical. Como adverte Howell (2005, p. 41), a questão comparativa importante não é verificar se o Estado exerce uma função regulatória, por meio do direito, sobre as relações de trabalho, já que a mesma é essencial ao desenvolvimento das forças produtivas; o ponto central dessa comparação deve ser a análise das formas específicas que a regulação assume, dos usos do direito e de suas conseqüências sobre os padrões de ação sindical.

Ao longo dos últimos dois capítulos, buscou-se apresentar o desenvolvimento histórico das formas de intervenção do Estado nas relações de trabalho por meio da regulação jurídica, assim como suas conseqüências sobre os padrões de ação sindical no Brasil e na Grã-Bretanha. Buscou-se demonstrar os objetivos que animaram a intervenção regulatória do Estado, os processos de construção social das instituições regulatórias, as formas resultantes de regulação das relações de trabalho e suas conseqüências em termos de padrões de ação sindical. Essa análise permitiu verificar que diferentes formas de controle e incentivos na forma de regulação jurídica exercem notável influência sobre o modo com os sindicatos organizam-se e agem, de modo a maximizar as oportunidades oferecidas. Todavia, um cotejamento direto das características fundamentais dos modelos de regulação e dos padrões de ação sindical nos dois países torna ainda mais evidente os efeitos de diferentes formas de regulação sobre a ação sindical.

Até o século XX, em ambas as nações, o Estado não desenvolveu uma intervenção regulatória sistemática sobre as relações de trabalho. Não havia ainda um aparato destinado à regulação e a produção legislativa incidente sobre as relações de trabalho era episódica e visava a solucionar problemas específicos. O intuito fundamental da ação regulatória era manter a ordem no espaço de trabalho e subordinar os trabalhadores às ordens de seus empregadores. Nesse sentido, os documentos legislativos criados no Brasil e na GrãBretanha tinham um claro caráter repressivo, prevendo sanções criminais para a ação organizada dos trabalhadores em busca de suas pretensões.

Essa regulação repressiva não foi suficiente, porém, para suprimir as organizações operárias. A despeito da proibição da ação sindical e das sanções a ela associadas, 
sindicatos floresceram e deram lugar a uma expressiva mobilização dos trabalhadores alimentada pelo sentimento de ressentimento. Os custos da organização e da ação, consideradas ilegais, eram elevados mas, ainda assim, o desejo dos trabalhadores de conquistar um marco legal mais favorável, em que suas agremiações pudessem existir e vocalizar suas demandas foi o combustível de movimentos combativos e autônomos. Não se trata, por óbvio, de apontar vantagens nos instrumentos regulatórios repressivos, mas é inegável que, tanto na Grã-Bretanha, quanto no Brasil, esses instrumentos conduziram a um padrão de ação sindical combativo, ainda que a extensão, intensidade e momento histórico em que esses movimentos surgiram tenha sido distinto nos dois países. Esse padrão de ação sindical não foi, certamente, produto único da repressão estatal, para ele contribuindo ainda o rápido desenvolvimento industrial nas grandes aglomerações urbanas, que ampliava o número de trabalhadores submetidos às mesmas experiências, fomentando a tomada de consciência sobre sua situação.

A proliferação de associações sindicais e o incremento de suas ações com efeitos perturbadores sobre a produção demandou respostas do Estado. O aumento dos conflitos trabalhistas conduziu ao reconhecimento sobre a necessidade de criar mecanismos de regulação das relações de trabalho para evitar os conflitos delas emergentes, assim como formas eficientes de processar capazes de processar disputas. Ademais, os governos em ambas as nações compreenderam que uma racionalização das relações de trabalho que permitisse a redução dos conflitos era fundamental também para responder a desafios econômicos específicos que enfrentavam. No caso brasileiro, esses desafios correspondiam ao esforço de desenvolvimento industrial, para o qual se julgava necessário regular extensivamente as relações de produção e organizar o trabalho para impedir que esse obstruísse os esforços governamentais e do capital nacional. No caso britânico, por sua vez, o desafio inicial era a superação do declínio relativo da indústria tradicional, com um acirramento da concorrência que se expressava na precarização das condições de trabalho e na depressão dos salários. O ponto de partida para uma intervenção regulatória sistemática nas relações de trabalho nas duas nações constituiu, portanto, o reconhecimento da dimensão econômica do conflito trabalhista e da racionalização das relações de trabalho. Esse reconhecimento ocorreu no final do século XIX na Grã-Bretanha e na década de 1930 no Brasil.

A partir desse reconhecimento, a regulação do trabalho em cada uma das nações desenvolveu uma trajetória própria. Imaginados como respostas instrumentais a desafios 
econômicos próprios de cada uma das nações, os modelos regulatórios adotados também haveriam de ser distintos, assim como os padrões de ação sindical produzidos. Em ambos os casos, no início de sua atividade de promoção de sistemas regulatórios, os governos perceberam que os sindicatos eram atores socialmente relevantes que deveriam participar da regulação do trabalho, na medida em que tinham a capacidade de organizar e controlar os trabalhadores. Não obstante, o sentido prático desse reconhecimento na montagem dos aparatos regulatórios foi diverso, replicando os valores e ideologias particulares que os justificavam. Conseqüentemente, o papel que os sindicatos passaram a exercer em cada um dos países foi distinto.

No Brasil, os ideais positivistas adaptados aos interesses da elite, juntamente com o projeto governamental nacional-desenvolvimentista, inspiraram uma solução baseada na regulação das relações de trabalho por meio de direitos positivos individuais, além da formação de uma estrutura de representação de interesses de matriz corporativista, à qual foram incorporados os sindicatos. O modelo empregou a legislação para definir condições gerais aplicáveis aos contratos de todos os trabalhadores, deixando pouco espaço para aos atores para a negociação. Conseqüentemente, os sindicatos desempenhavam um papel secundário na regulação das relações de trabalho. A função para eles imaginada pelo modelo era a de auxiliar o Estado em sua política desenvolvimentista, organizando os trabalhadores e controlando suas condutas. Para tanto, os sindicatos foram organizados em uma estrutura oficial de representação de interesses do trabalho e capital com três níveis (nacional, estadual e local) que atuava como meio de concerto entre os atores. O reconhecimento sindical era realizado pela burocracia estatal e, por meio dele, a agremiação era enquadrada na estrutura oficial, com monopólio representacional da categoria na unidade territorial local. A partir desse momento, o sindicato recebia contribuições compulsórias deduzidas dos trabalhadores e de seus empregadores.

Na Grã-Bretanha, por sua vez, os valores liberais e pluralistas promoveram a convicção na capacidade de auto-regulação dos atores. O Estado, assim como trabalhadores e empresários, entendeu que o melhor instrumento de regulação das relações de trabalho seria a negociação coletiva. Após séculos de uma legislação punitiva e injusta, além de ataques judiciais constantes às conquistas legislativas, os sindicatos preferiram garantir uma imunidade geral para suas ações em relação ao Common Law à obterem uma série de direitos positivos que, acreditavam, poderiam ser interpretados em seu prejuízo. Os empresários, por sua vez, preferiam adotar soluções negociadas que mantivessem seu 
poder de gestão dos processos de trabalho à submeterem-se à regulação legislativa. Essa opinião comum havia sido reforçada pelo êxito das experiências de construção de órgãos de negociação permanente entre associações de empresários e sindicatos em alguns setores da economia. Baseando-se nessas experiências, o Estado decidiu promover as negociações coletivas entre sindicatos e empregados ou suas associações, julgando que os acordos a que chegariam seriam um eficiente instrumento de regulação das relações, além de oferecer procedimentos para a solução de possíveis disputas.

Em decorrência, a ação regulatória do Estado assumiu o papel de oferecer recursos organizacionais aos atores para promover condições de negociação de acordos versando sobre as relações de trabalho e a solução de conflitos. Essa ação incluía a concessão de incentivos para que os atores formassem instituições de negociação e a criação dessas instituições para atores pouco organizados. Ao longo do desenvolvimento desse modelo regulatório, o âmbito em que era promovida a negociação alterou-se, para se adaptar a demandas específicas da economia. Em um primeiro momento, o Estado promoveu a negociação setorial para estabelecer salários e condições gerais de trabalho que reduzissem a concorrência entre empresários e a insatisfação dos trabalhadores que promovia conflitos. Em um segundo momento, a necessidade de modernizar os processos produtivos fez com que o Estado deslocasse sua atenção para o interior das firmas. Foi nesse nível que ele fomentou a negociação, prevendo formas de formalização do diálogo que representantes sindicais mantinham diariamente com a gerência, de modo a permitir transformações negociadas nas práticas produtivas.

O Estado britânico furtou-se, portanto, de regular as condições substantivas da relação de trabalho, permitindo que os próprios atores o fizessem, atentando para as especificidades dos setores econômicos e das empresas individuais. A legislação foi utilizada para definir condições de trabalho, notadamente salários, apenas secundariamente, quando a negociação não era possível. Nesse sistema, o papel do direito era o de oferecer instrumentos de ação à administração estatal que lhe permitisse fomentar a livre negociação pelos atores. Por assim dizer, a ação regulatória estatal deveria complementar os esforços negociais dos atores, não substituí-los.

Enquanto no Brasil, a regulação jurídica era substantiva, determinando as condições da relação de trabalho e, assim, substituindo a capacidade negocial dos atores, na GrãBretanha ela era fundamentalmente procedimental, potencializando a ação negocial de sindicatos e associações empresariais. As conseqüências para os sindicatos desse modelo 
regulatório fundado nas negociações coletivas também eram diversas daquelas verificadas no caso brasileiro. Na Grã-Bretanha, os sindicatos mantinham sua autonomia em relação ao Estado e eram protagonistas na definição dos termos da relação de trabalho. Essa posição de destaque no aparato regulatório, alimentada por recursos organizacionais distribuídos pelo Estado para assegurar a aptidão dos sindicatos para negociar as condições de trabalho, conferia um invejável poder aos sindicatos.

Entretanto, o modelo não oferecia nenhuma proteção rígida à posição dos sindicatos. Não havia direitos positivos ou garantias à ação sindical, tais como o direito ao reconhecimento sindical ou às greves. A ação dos sindicatos estava inteiramente fundada, do ponto de vista jurídico, na imunidade de que gozava em suas ações em relação ao controle judicial. Essas imunidades, como se demonstrou ao tratar do caso britânico, eram facilmente confundidas com privilégios exacerbados, o que tornava os sindicatos mais vulneráveis a ataques políticos. Essa vulnerabilidade facilitou a profunda alteração do modo de regulação jurídica das relações de trabalho, promovida na Grã-Bretanha por Margareth Thatcher, que buscava enfraquecer os sindicatos e desconstruir o aparato existente de negociação coletiva, substituindo-o pela negociação individual entre empregados e gerência de recursos humanos, como forma de reduzir a resistência dos trabalhadores e facilitar a flexibilização dos processos produtivos. A partir de então, a função primordial do aparato de regulação jurídica do trabalho naquele país passou a ser o exercício de controles sobre a ação sindical e a definição de padrões mínimos do contrato de trabalho.

Essas significativas transformações pelas quais passou o modelo britânico, contrapõem-se à estabilidade do modelo brasileiro construído por regimes autoritários, que mantém inalterados seus pilares, mesmo após a promulgação de uma nova Constituição Federal e um período de relativa estabilidade democrática. Tanto a estabilidade do modelo brasileiro, quanto a reforma do modelo britânico, podem ser explicadas por suas características. O sistema regulatório brasileiro, baseado em extensa legislação das condições de trabalho, aumenta os custos de reforma. Ademais, a intervenção nas relações de trabalho no país mobiliza um conjunto de instituições, tais como o Ministério do Trabalho e suas Delegacias, a Justiça do Trabalho e o Ministério Público do Trabalho, compostas de burocracias que promovem sua manutenção. As forças envolvidas em sua defesa incluem, ainda, os próprios sindicatos, incorporados em uma estrutura oficial que distribui recursos organizacionais e financeiros, garantindo o acesso a fundos públicos. As 
associações sindicais acomodaram-se confortavelmente nessa posição e temem a perda de seus benefícios. Mas além da posição privilegiada dos sindicatos, o modelo de regulação jurídica conta com seu apoio porque é considerado uma opção preferível à livre negociação entre os atores em um contexto de retomada do poder dos empresários de impor condições de trabalho, proliferação de formas precárias de emprego e de conseqüente enfraquecimento dos sindicatos. Os sindicatos preferem, em virtude de seu reduzido poder de barganha, a manutenção de um modelo de regulação jurídica fundado em um corpo fixo de normas individuais aplicáveis aos contratos de trabalho. A legislação trabalhista é mesmo reconhecida, entre trabalhadores e alguns sindicatos, como um refúgio contra as práticas precárias e uma inestimável conquista popular.

A rigidez e o apoio social ao modelo explicam a manutenção dos pilares do modelo regulatório brasileiro. Ainda assim, a inadequação da legislação trabalhista, editada quando a indústria brasileira não havia atingido a maturidade, faz com que novas formas de relação de trabalho desenvolvam-se à margem dela. Apenas uma parcela dos trabalhadores, em regra os que ocupam melhores cargos, tem suas relações de trabalho reguladas pela CLT e pode usufruir de seus direitos. O modelo regulatório negligencia um conjunto de formas de relação de trabalho que se desenvolvem à margem do próprio e, diante de enormes pressões por arranjos mais flexíveis, tem sido apenas pontualmente alterado.

O papel menos proeminente que a legislação exercia no sistema britânico dotava-o de maior plasticidade. Os custos de reforma eram menores e, diante da corrosão do consenso em torno da posição dos sindicatos no sistema regulatório, em virtude da propagação de uma narrativa que exagerava o nível de conflitos trabalhistas e ações sindicais, apontando-o como causa da crise econômica, o apoio social à reforma era intenso. A ação regulatória fundamental consistia em oferecer incentivos à negociação coletiva, que podiam ser facilmente removidos. Ademais, como afirmado anteriormente, a ausência de direitos protegendo os sindicatos facilitava seu enfraquecimento. Assim, foi mais simples reformar as instituições regulatórias na Grã-Bretanha, promovendo a descoletivização das relações de trabalho.

As trajetórias singulares de construção de modelos de regulação jurídica do trabalho no Brasil e na Grã-Bretanha também determinaram diferenças nos padrões de ação sindical verificadas nesses países. A incorporação dos sindicatos a uma estrutura oficial hierarquizada, o monopólio representacional (unicidade) e o acesso a uma fonte de recursos de caráter tributário, isto é, uma contribuição compulsória cobrada pelo Estado, 
são características fundamentais do modelo brasileiro que definiram uma atuação sindical burocrática, distante do local de trabalho, fortemente relacionada ao Estado e, em certa medida, dependente do mesmo. A incorporação do sindicato na estrutura oficial de representação garantia o reconhecimento permanente do mesmo, sua participação nas negociações coletivas e recursos financeiros. A ação sindical, que constituía normalmente uma negociação formal com empresários e o governo, era distante das bases. Ademais, os termos negociados estendiam-se a toda a categoria. Portanto, os trabalhadores não eram incentivados à filiação, por um lado, e os sindicatos prescindiam de filiados, por outro. Em decorrência, os sindicatos não se faziam presentes no interior das empresas e a militância era reduzida.

Evidentemente, alguns sindicatos brasileiros apresentam padrões de organização e ação muito diversos dos acima descritos. Especialmente nos setores mais dinâmicos da economia, assistiu-se, no final da década de 1970, a emergência de um novo sindicalismo, mais presente no interior das empresas e ligado às demandas das bases, menos burocrático e colaborativo e mais pragmático nas negociações. Contudo, a erosão do poder de barganha dos sindicatos no período posterior, somada à incorporação dessas organizações à estrutura oficial de representação, diluiu os caracteres que as distinguiam dos sindicatos tradicionais. Como produto da função que lhes foi atribuída pelo modelo de regulação do trabalho, os sindicatos brasileiros acomodaram-se à sua função de clubes de serviços e administradores de fundos de pensão.

A extensiva legislação trabalhista no Brasil reduziu o papel dos sindicatos na negociação das condições de trabalho, situação inversa à verificada no caso britânico, em que as atividades de negociação eram fundamentais para a regulação do trabalho. Entretanto, a postura assumida pelos sindicatos na Grã-Bretanha não era mais colaborativa com os empresários. Ao contrário, o sindicalismo britânico assumiu uma posição adversária, competitiva e contrária à colaboração, quer com o Estado, quer com o empresariado. O elevado poder dos sindicatos, resultante do papel que assumiram no sistema de regulação britânico, traduzia-se em uma elevada capacidade de mobilizar as bases em torno de demandas e impor sanções na forma de limites ou interrupção da produção. Além disso, como resultado do incentivo estatal à formalização de mecanismos de negociação no interior das empresas, os sindicatos britânicos fizeram-se presentes junto a suas bases. 
Esse padrão de ação foi, entretanto, modificado pela eliminação dos incentivos antes conferidos à negociação coletiva, pela introdução de limites legais sobre as ações sindicais e a atribuição de responsabilidade por atos considerados danosos. A descoletivização das relações de trabalho promovida nas últimas décadas para permitir maior flexibilidade nos arranjos produtivos sem interferências ou resistências dos trabalhadores organizados, tornou os sindicatos menos relevantes. Com o fim da negociação coletiva e diante da ausência de procedimentos legais, os sindicatos tiveram de lutar pelo seu reconhecimento por parte das empresas. Mesmo a introdução de um procedimento legal para o reconhecimento dos sindicatos, não alterou essa situação, já que a exigência de $40 \%$ dos trabalhadores é muito elevada.

Como não poderia deixar de ser, a perda do poder de barganha alterou o comportamento dos sindicatos, aumentando sua predisposição a negociações e concessões. Sua posição em relação à legislação também foi alterada: diante das dificuldades enfrentadas para organizar a ação coletiva, os sindicatos britânicos passaram a defender seletivamente direitos para os trabalhadores.

Em suma, dois modelos distintos de regulação das relações de trabalho, que atribuíam diferentes funções ao direito e aos sindicatos, contribuíram para a produção de dois padrões igualmente distintos de ação sindical. Nas últimas décadas, contudo, os sindicatos da Grã-Bretanha e do Brasil têm sofrido pressões comuns. A proliferação de formas precárias de emprego, da subcontratação e do próprio desemprego desafia as formas tradicionais de atuação dos sindicatos. Além disso, a adoção de estratégias de regulação individual das relações de trabalho no interior das firmas, por meio de estratégias de gestão de recursos humanos, tem colocado em xeque a representação sindical.

Entretanto, a análise dos instrumentos regulatórios empregados pelo Brasil e pela Grã-Bretanha e de suas influências sobre a ação sindical permitem identificar formas de resgatar o papel dos sindicatos em um contexto de acumulação flexível. A experiência do Employment Protection Act, de 1975, embora tenha fracassado, parece apontar um modelo de regulação virtuoso para os sindicatos. Nesse documento, direitos individuais foram concedidos como um instrumento para criar condições para a ação coletiva. Esses direitos apenas reforçavam as capacidades de organização e ação coletiva dos sindicatos, sem fixar o conteúdo das relações de trabalho. Pode-se considerar que esses direitos não limitam a capacidade das empresas de controlar os processos produtivos de modo flexível, mas oferecem aos sindicatos recursos organizacionais para encaminhar demandas. 


\section{BiBLIOGRAFIA}

ABREU, Alzira Alves de; BELOCH, Israel; LATTMAN-WELTMAN, Fernando (coords.). Dicionário Histórico-Biográfico Brasileiro: pós-1930. Rio de Janeiro: FGV/CPDOC, 2008. Versão em CD ROM.

ALONSO, Angela. Crítica e contestação: o movimento reformista da geração 1870. Revista Brasileira de Ciências Sociais. São Paulo, vol.15, no.44, out. de 2000, pp. 35-55. ALVES, Ataulpho; BAPTISTA, Wilson. O bonde São Januário. Quem trabalha é que tem razão (partitura para canto e piano). Rio de Janeiro: Editora Música Brasileira, [ca. 1940]. ANTUNES, Ricardo. A rebeldia do trabalho. São Paulo: Editora Ensaio/Unicamp, 1988.

BENDIX, Reinhard. Construção Nacional e Cidadania: estudos de nossa ordem social em mudança. São Paulo: EDUSP, 1996.

BONOLI, Giuliano. Political Institutions, Veto Points, and the Process of Welfare State Adaptation in: PIERSON, Paul (org.). The New Politics of the Welfare State. Oxford: Oxford University Press, 2001, p. 238-64.

BOYER, Robert; SAILLARD, Yves (Eds.). Régulation Theory: the state of art. Londres: Routledge, 2002.

BOTTOMORE, Tom. Citizenship and and Social Class, forty years on in: MARSHALL, Thomas Humphey; BOTTOMORE, Tom. Citizenship and Social Class. Londres: Pluto Press, 1992, pp. 55-93.

BRASIL. INSTITUTO BRASILEIRO DE GEOGRAFIA E ESTATÍSTICA (IBGE). Sindicatos: indicadores sociais. Rio de Janeiro: IBGE, 2003.

- Pesquisa Mensal de Emprego. Suplemento Associativismo, Representação de Interesses e Intermediação Política. Abril de 1996. Disponível em <ftp://ftp.ibge.gov.br/Indicadores_Sociais/Associativismo_Representacao_de_Interesses_e _Intermediacao_Politica de IBGE - Pesquisa Mensal de Emprego - Tema Associativismo>. Acesso em 02.09.07.

CARDOSO, Adalberto Moreira. A filiação sindical no Brasil in: Dados [online]. 2001, vol.44, no.1. Disponível em <http://www.scielo.br/scielo.php?script=sci_arttext\&pid=S 0011-52582001000100003\&lng=en\&nrm=iso $>$. Acesso em 10.06.06. 
. O sindicalismo corporativo não é mais o mesmo. Novos Estudos CEBRAP. São Paulo, no. 48, 1997, pp. 97-119.

CARDOSO, Fernando Henrique. Autoritarismo e Democratização. Rio de Janeiro: Paz e Terra, 1975.

CARDOSO JR., José Celso; JACCOUD, Luciana. Políticas Sociais no Brasil: organização, abrangência e tensões da ação estatal in: JACCOUD, Luciana (org). Questão Social e Políticas Sociais no Brasil Contemporâneo. Brasília: IPEA, 2005, pp. 181-255.

CARVALHO, José Murilo de. Cidadania no Brasil: o longo caminho. $6^{\mathrm{a}}$ ed. Rio de Janeiro: Civilização Brasileira, 2004.

CESARINO JUNIOR, Antônio Ferreira. Direito social brasileiro. São Paulo: Livraria Martins Fontes, 1940.

COSTA, Vanda Maria Ribeiro. Origens do corporativismo brasileiro in: BOSCHI, Renato R. Corporativismo e Desigualdade: a construção do espaço público no Brasil. Rio de Janeiro: IUPERJ e Rio Fundo, 1991, pp. 113-45.

COSTA, Márcia da Silva. O sistema de relações de trabalho no Brasil: alguns traços históricos e sua precarização atual in: Revista Brasileira de Ciências Sociais. São Paulo, vol. 20, no. 50, out. de 2005, pp. 111-31.

DEPARTAMENTO INTERSINDICAL DE ESTATÍSTICA E ESTUDOS SOCIOECONÔMICOS (DIEESE). Taxa de judicialização das negociações coletivas de trabalho no Brasil 1993-2005. Estudos \& Pesquisas. São Paulo, ano 2, no. 21, jun. de 2006.

DIAS, Everardo. História das Lutas Sociais no Brasil. 2a ed. São Paulo: Alfa-Omega, 1977.

DICKENS, Linda; HALL, Mark. Labour Law and Industrial Relations: a new settlement? in: EDWARDS, Paul (ed.). Industrial Relations: theory and practice. $2^{\mathrm{a}}$ ed. Oxford: Blackwell.

DOBBIN, Frank. Forging Industrial Policy: The United States, Britain and France in the Railway Age. Nova Iorque: Cambridge University Press, 1994. 
DRAIBE, Sônia Miriam. As políticas sociais do regime militar brasileiro: 1964-1984 in: SOARES, Gláucio Ary Dillon; D’Araujo, Maria Celina (orgs.). 21 anos de regime militar: balanço e perspectivas. Rio de Janeiro: FGV, 1994, pp. 271-309.

DEPARTMENT OF TRADE AND INDUSTRY (DTI). Fairness at work. White-paper presented to the Parliament. London: HMSO, 1998.

EDWARDS, Paul; HALL, Mark; HYMAN, Richard; MARGISON, Paul; SISSON, Keith; WADDINGTON, Jeremy; WINCHESTER, David. Great Britain: From Partial Collectivism to Neo-Liberalism to Where? in: FERNER, Anthony; HYMAN, Richard (eds.). Changing Industrial Relations in Europe. $2^{\mathrm{a}}$ ed. Oxford: Blackwell, 1998.

ESPING-ANDERSEN, Gøsta. Social foundations of postindustrial economies. Oxford: Oxford University Press, 1999.

EVANS, Peter; RUESCHEMEYER, Dietrich e SKOCPOL, Theda. Bringing the State Back in. Nova Iorque: Cambridge University Press, 1985.

FAUSTO, Boris. Trabalho Urbano e Conflito Social. 5a ed. Rio de Janeiro: Bertrand Brasil, 2000a. História do Brasil. $8^{\mathrm{a}}$ ed. São Paulo: EDUSP, 2000b.

GEARY, Dick. European labor protest, 1848-1939. Nova Iorque: St. Martin’s Press, 1981. GOLDEN, Miriam; WALLERSTEIN, Michael; LANGE, Peter. Postwar Trade-Union Organization and Industrial Relations in Twelve Countries in: KISTSCHELT, Herbert; LANGE, Peter; MARKS, Gary; STEPHENS, John D. Continuity and Change in Contemporary Capitalism. Cambridge, RU: Cambridge University Press, 2005, pp. 194230.

GOLDSTONE, Jack. Comparative historical analysis and knowledge accumulation in the study of revolutions in: MAHONEY, James; RUESCHEMEYER, Dietrich. Comparative Historical Analysis in the Social Sciences. Cambridge: Cambridge University Press, pp. 41-90.

GOLDTHORPE, John H. Industrial Relations in Great Britain: a critique of reformism. Politics \& Society. Vol. 4, no. 4, 1974, pp. 419-452.

. On Sociology. Oxford: Oxford University Press, 2000. 
HALL, Peter. The political economy of Europe in an era of interdependence in: KITSCHELT, Herbert; LANGE, Peter; MARKS, Gary; STEPHENS, John D (ed). Continuity and Chang in Contemporary Capitalism. Cambridge: Cambridge University Press, 2003, pp. 135-63.

HALL, Peter; TAYLOR, Rosemary C.R. Political Science and the Three New Institutionalisms in: Political Studies. Vol. 44, no. 5, dez. de 1996, pp. 936-957.

HIRSCHMAN, Albert. Saída, voz e lealdade: reações ao declínio de firmas, organizações e estados. São Paulo: Perspectiva, 1973.

HOBSBAWM, Eric. Da Revolução Industrial Inglesa ao Imperialismo. Rio de Janeiro: Forense Universitária, 1978.

HOWELL, Chris. Trade Unions and the State. The Construction of Industrial Relations Institutions in Britain, 1890-2000. Princeton, NJ e Oxford, RU: Princeton University Press, 2005.

HYMAN, Richard. Trade Unions and the Disaggregation of the Working Class in: REGINI, Marino (ed.). The Future of Labour Movements. London: Sage, 1992, pp. 150168.

. The Historical Evolution of the British Industrial Relations in: EDWARDS, Paul (ed.). Industrial relations: Theory and Practice. 2a ed. Oxford, RU: Blackwell, 2003.

IANNI, Octavio. O Colapso do Populismo no Brasil. Rio de Janeiro: Civilização Brasileira, 1968.

KAHN-FREUND, Otto. Legal Framework in: FLANDERS, Allan; CLEGG, Hugh Armstrong (eds.) The System of Industrial Relations in Great Britain: Its History, Law and Institutions. Oxford, RU: Blackwell, 1954.

Trade unions, the law and society in: The Modern Law Review. Vol. 33, no. 3, mai. de 1970, pp. 241-267.

KERSLEY, Barbara; ALPIN, Carmen; FORTH, John; BRYSON, Alex; BEWLEY, Helen; DIX, Gill; OXENBRIDGE, Sarah. Inside the Workplace: Findings from the 2004 Workplace Employment Relations Survey. Routledge: London, 2006.

KORPI, Walter. The Democratic Class Struggle. Londres: Routledge \& Kegan Paul, 1983. 
LEHMBRUCH, Gerhard. Concertation and the structure of corporatist networks in: GOLDTHORPE, John H (ed.). Order and conflict in contemporary capitalism. Oxford: Clarendon Press, 1984, pp. 60-80.

JESSOP, Bob. Thatcherism and Flexibility. The White Heat of a Post-Fordist Revolution in: JESSOP, Bob; KASTENDIEK, H.; NIELSEN, K.; PEDERSEN, O. K. (eds). The Politics of Flexibility: Restructuring State and Industry in Britain, Germany and Scandinavia. Aldershot: Edward Elgar, 1994, pp. 135-161.

JESSOP, Bob; SUM, Ngai-Ling. Beyond the Regulation Approach. Putting Capitalist Economies in their Place. Cheltham: Edward Elgar, 2006.

KEEP, Ewart; RAINBIRD, HELEN. Training in: EDWARDS, Paul (ed.). Industrial Relations: Theory and Practice. $2^{\mathrm{a}}$ ed. Oxford: Blackwell, 2003, pp. 392-419.

KING, Desmond; WOOD, Steward. The political economy of neoliberalism: Britain and the United States in 1980s in: KITSCHELT, Herbert; LANGE, Peter; MARKS, Gary; STEPHENS, John D. (eds.). Continuity and Change in Contemporary Capitalism. Cambridge, UK: Cambridge University Press, 2005, pp. 371-397.

LENIN, Vladimir Ilitch. Que fazer? As Questões Palpitantes do Nosso Movimento. São Paulo: Hucitec, 1978.

LIBERSON, Stanley. Small N's and Big Conclusions: An Examination of the Reasoning in Comparative Studies Based on a Small Number of Cases. Social Forces. Chapel Hill, North Carolina, Vol. 70, No. 2, dec. de 1991, pp. 307-20.

MAIER, Charles. Preconditions for Corporatism in: GOLDTHORPE, John H (ed.). Order and conflict in contemporary capitalism. Oxford: Clarendon Press, 1984, pp. 39-59.

MARONI, Amnéris. A estratégia da recusa. São Paulo: Brasiliense, 1982.

MARKS, Gary. Unions in politics: Britain, Germany and the United States in the nineteenth and early twentieth centuries. Princeton: Princeton University Press, 1989.

MARSHALL, Tomas Humphey. Citizenship and social class in: MARSHALL, Thomas Humphey; BOTTOMORE, Tom. Citizenship and Social Class. Londres, Pluto Press, 1992, pp. 3-51.

MARTINS, Heloísa Helena Teixeira de Souza. O Estado e a burocratização do sindicato no Brasil. 2a ed. São Paulo: Hucitec, 1989. 
MARX, Karl. Capital: Crítica da Economia Política. Livro Primeiro. Vol. 1. Trad.

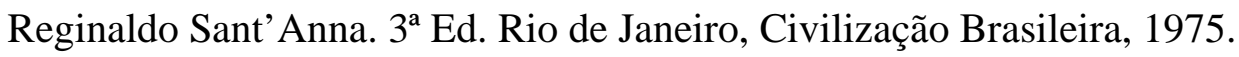

McADAM, Doug; McCARTHY, John D.; ZALD, Mayer N. Comparative Perspectives on Social Movements: political opportunities, mobilizing structures and cultural framings. Nova Iorque: Cambridge University Press, 1996.

MOREIRA, Vânia Maria Losada. Nacionalismo e reforma agrária nos anos 50. Revista Brasileira de História. São Paulo, vol. 18, no. 35, 1998. Disponível em $<$ http://www.scielo.br>. Acesso em 11.06.2006.

OFFE, Claus. The Attribution of Public Status to Interest Groups, Observations on the West German Case in: BERGER, Suzanne. Organizing Interests in Western Europe (ed.). Cambridge, RU: Cambridge University Press, 1981, pp. 123-58.

A democracia partidária competitiva e o "welfare state” keynesiano: fatores de estabilidade e desorganização in: (org.). Problemas Estruturais do Estado Capitalista. Trad. Bárbara Freitag. Rio de Janeiro: Tempo Brasileiro, 1984, pp. 356-386.

OFFE, Claus; LENHARDT, Gero. La Politica Social y La Teoria del Estado in: OFFE, Claus; KEANE, John (Eds.). Contradicciones en el Estado de Bienestar. Alianza Editorial: Madrid, 1990, pp. 72-104.

OLIVEIRA, Francisco de. Crítica da razão dualista e O ornitorrinco. São Paulo: Boitempo, 2006.

OLIVEIRA, Marco Antonio de. Tendências recentes das negociações coletivas do Brasil in: SANTANA, Marco Aurélio; RAMALHO, José Ricardo. Além da Fábrica: trabalhadores, sindicatos e a nova questão sindical. São Paulo: Boitempo, 2003.

PECK, Jamie. Work-place: The Social Regulation of Labor Markets. New York: Guilford Press, 1996.

Workfare states. New York: Guilford Press, 2001.

PEREIRA, Luiz. Trabalho e desenvolvimento no Brasil. São Paulo: DIFEL, 1965.

PIERSON, Paul. Coping with permanent austerity: Welfare state restructuring in affluent democracies in: (org). The New Politics of the Welfare State. Oxford: Oxford University Press, 2001, pp. 410-56. 
POLANYI, Karl. A grande transformação: as origens da nossa época. $6^{\mathrm{a}}$ ed. Rio de Janeiro: Campus, 2000.

PRZEWORSKI, Adam. Capitalism and Social Democracy. Cambridge e Paris: Cambridge University Press e Editions de la Maison des Sciences de l’Homme, 1985.

REGINI, Marino. The Conditions for Political Exchange: How Concertation Emerged and Collapsed in Italy and Great Britain in: GOLDTHORPE, John H (ed.). Order and conflict in contemporary capitalism. Oxford: Clarendon Press, 1984, pp. 124-142.

Introduction: the Past and the Future of Social Studies of Labour Movements in: REGINI, Marino (ed.). The Future of Labour Movements. London: Sage, 1992, pp. 1-16.

REID, Alastair J. United we stand: A History of Britain’s Trade Unions. Londres: Penguin, 2005.

REINO UNIDO DA GRÃ-BRETANHA E IRLANDA DO NORTE. Report of the Royal Commission on Trade Unions and Employers' Associations, 1965-1968 (Lord Donovan, Chairman). Londres: H.M.S.O., Cmnd. 3623.

RODRIGUES, Iram Jácome. Comissão de Fábrica e Trabalhadores na Indústria. São Paulo: Cortez/FASE, 1990.

RODRIGUES, Leôncio Martins. O sindicalismo corporativo no Brasil in: Partidos $e$ Sindicatos. São Paulo: Ática, 1990, pp. 47-76.

RUESCHEMEYER, Dietrich. Can one or few cases yield theoretical gains? In: MAHONEY, James; RUESCHEMEYER, Dietrich. Comparative Historical Analysis in the Social Sciences. Cambridge: Cambridge University Press, pp. 305-336.

RUESCHEMEYER, Dietrich; STEPHENS, Evelyne Huber; STEPHENS, John D. Capitalist development and democracy. Cambridge, RU: Polity Press, 1991.

RÜSCHE, Georg; KIRCHHEIMER, Otto. Pena y estructura social. Derecho Penal y Criminología. Bogotá: Temis, 1984.

SANTOS, Wanderley Guilherme dos. Cidadania e Justiça. Rio de Janeiro: Campus, 1979. SKOCPOL, Theda. States and Social Revolutions: a comparative analysis of France, Russia and China. Cambridge, Reino Unido: Cambridge University Press, 1979. 
. Bringing the State Back in: Strategies of Analysis in Current Research in: EVANS, Peter; RUESCHEMEYER, Dietrich; SKOCPOL, Theda (eds.). Bringing the State Back in. Nova Iorque: Cambridge University Press, 1985, p. 3-43.

SOSKICE, David. Divergent Production Regimes: Coordinated and Uncoordinated Market Economies in the 1980s and 1990s in: KITSCHELT, Herbert; LANGE, Peter; MARKS, Gary; STEPHENS, John D (ed). Continuity and Change in Contemporary Capitalism. Cambridge: Cambridge University Press, 2003, p. 101-34.

SOSKICE, David; HALL, Peter. Varieties of Capitalism: the institutional foundations of comparative advantage. Oxford: Oxford University Press, 2001.

STEINMO, Sven; THELEN, Kathleen Ann; LONGSTRETH, Frank (eds). Structuring Politics: Historical Institutionalism in Comparative Analysis. New York: Cambridge University Press, 1992.

STEPAN, Alfred. State Power and the Strength of Civil Society in the Southern Cone of Latin America in: EVANS, Peter; RUESCHEMEYER, Dietrich e SKOCPOL, Theda. Bringing the State Back in. New York: Cambridge University Press, 1985, pp. 317-346.

STEPHENS, John D; HUBER, Evelyne; RAY, Leonard. The Welfare State in Hard Times in: KITSCHELT, Herbert; LANGE, Peter; MARKS, Gary; STEPHENS, John D (eds). Continuity and Change in Contemporary Capitalism. Cambridge: Cambridge University Press, 2003, pp. 164-93.

SWANK, Duane. Political Institutions and Welfare State Restructuring in: PIERSON, Paul (org). The New Politics of the Welfare State. Oxford: Oxford University Press, 2001, p. 197-237.

TARROW, Sidney. Power in movement: Social Movements and Contentious Politics. $2^{\mathrm{a}}$ ed. Cambridge, RU: Cambridge University Press, 1998.

THOMPSON, Edward Palmer. The making of the English working class. Nova Iorque: Vintage Books, 1966.

TILLY, Charles. From mobilization to revolution. Reading, MA: Addison-Wesley, 1978.

TURNER, H. A. The Donovan Report. The Economic Journal. Vol. 79, No. 313, mar. de 1969, pp. 1-10. 
SCHMITTER, Philippe; LEHMBRUCH, Gerhard. Trends toward corporatist intermediation. London: Sage Publications, 1979.

SIMÃO, Aziz. Sindicato e Estado. São Paulo: Dominus, 1966.

STEINFELD, Robert J. Coercion, Contract and Free Labor in the Nineteenth Century. Cambridge, RU: Cambridge University Press, 2001.

VIANNA, Francisco José de Oliveira. Instituições Políticas Brasileiras. Brasília: Senado Federal, Secretaria Especial de Editoração e Publicação, 1999.

VIANNA, Segadas. O sindicato no Brasil. Rio de Janeiro: [Serviço de Documentação do Ministério do Trabalho, Indústria e Comércio], 1953.

VISSER, Jelle (1992). The strength of Union Movements in Advanced Capitalist Democracies: Social and Organizational Variations in: REGINI, Marino (ed). The Future of Labour Movements. London: Sage, 1992, p. 17-52.

WEBER, Max. Objective possibility and adequate causation in historical explanation in: . The Methodology of Social Sciences. Nova Iorque: The Free Press, 1949. Economia y Sociedad. Esbozo de Sociología Comprensiva. Trad. José Medina Echavarría, Juran Roura Parella, Eugenio Ímaz, Eduardo Garcia Máynez e José Ferrater Mora. 2a ed.15ª Reimpressão. México: Fondo de Cultura Económica, 2004.

WEDDERBURN, Lord. Labour Law and Freedom: Further Essays in Labour Law. London: Lawrence and Wishart, 1995.

WEIR, Margaret; ORLOFF, Ann Shola; SKOCPOL, Theda. The Politics of Social Policy in the United States. Princeton: Princeton University Press, 1988.

WOOD, Stewart (2001). Labour Market Regimes Under Threat? Sources of Continuity in Germany, Britain, and Sweden in: PIERSON, Paul (org). The New Politics of the Welfare State. Oxford: Oxford University Press, pp. 368-409. 